\title{
JAMES MACANDREW OF OTAGO \\ SLIPPERY JIM OR A LEADER STAUNCH AND TRUE?
}

BY

RODERICK JOHN BUNCE

\begin{abstract}
A thesis
submitted to Victoria University of Wellington

in fulfilment of the requirements for the degree of

Doctor of Philosophy
\end{abstract}

Victoria University of Wellington

2013 



\begin{abstract}
James Macandrew, a Scotsman who migrated to Dunedin in 1851, was variously a businessman, twice Superintendent of Otago Province, an imprisoned bankrupt and a Minister of the Crown. He was an active participant in provincial and colonial politics for 36 years and was associated with most of the major political events in New Zealand during that time.
\end{abstract}

Macandrew was a passionate and persuasive advocate for the speedy development of New Zealand's infrastructure to stimulate the expansion of settlement. He initiated a steamer service between New Zealand and Australia in 1858 but was bankrupt by 1860 . While Superintendent of Otago in 1860 and 1867-76 he was able to advance major harbour, transport and educational projects. As Minister of Public Works in George Grey's Ministry from 1878-79 he promoted an extensive expansion of the country's railway system. In Parliament, he was a staunch advocate of easier access to land for all settlers, and a promoter of liberal social legislation which was enacted a decade later by the Seddon Government.

His life was interwoven with three influential settlers, Edward Gibbon Wakefield, Julius Vogel and George Grey, who variously dominated the political landscape. Macandrew has been portrayed as an opportunist who exploited these relationships, but this study will demonstrate that while he often served these men as a subordinate, as a mentor he influenced their political beliefs and behaviour.

Macandrew's contribution to New Zealand politics and history has been neither widely nor impartially discussed. His activities, particularly as a provincial Superintendent, as a leader of the opposition to the abolition of the provinces and as a government minister, have elicited accounts which range from adulation to anathema, and descriptions of him range from 'A leader staunch and true' to 'Slippery Jim.'

This biography explores the origins of Macandrew's values and philosophy, traces his life story, and evaluates his role in New Zealand history. It examines his career as a Scotsman abroad and as a settler who exploited the boom and bust economy of the new colony. It also investigates the events which diminished his reputation and curtailed his career.

Macandrew is revealed as an overlooked Scottish Presbyterian of conservative social values, liberal political ideals and visionary economic views, whose enthusiasms often exceeded his skills and led to the failure of many of his far-sighted and promising projects. He was a self-confident individual who had a substantial influence on his adopted country. 



\section{ACKNOWLEDGMENTS}

James Macandrew entered my consciousness in 1981 when I undertook research on the early settlement of Otago and he has demanded a biography ever since. Knowledge of Otago's settlers often stops at William Cargill and Thomas Burns, but Macandrew played an equally important role in making Dunedin, Otago and New Zealand the wonderful places they are.

I have been encouraged to write his biography by Professor David McKenzie and Professor Tom Brooking of Dunedin who both receive my thanks for their support.

At Victoria University of Wellington I have benefited from the professional oversight of my supervisors, Associate Professor Jim McAloon and Professor James Belich without whom this thesis would not have eventuated.

Professional help was provided in Dunedin by Alison Breeze of the Dunedin City Archives, Jill Haley of the Otago Settlers Museum and Alison Clarke of the Hocken Library. In Wellington assistance came from David Colquhoun of the Alexander Turnbull Library, Katie de Roo of Archives New Zealand and Lindsay Milne of the Parliamentary Library. I thank you all.

Macandrew descendants were always helpful with discussion and the loan and use of family records. I wish to thank Kate Wilson of Middlemarch, Jane Harcourt of Karori and Anne Hubbard of Raumati.

Lisa Sacksen was a tolerant roommate for the duration while Louis Schmitt executed a professional proof read. Thank you both.

My wife Elizabeth has supported me through the gestation, research and writing of this thesis with encouragement, discussion and challenge. Thank you Elizabeth for your love and support. 



\section{CONTENTS}

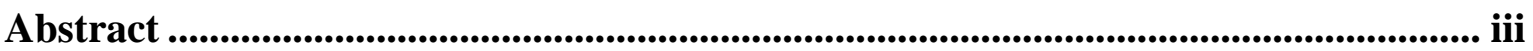

Acknowledgments ........................................................................................................................................v

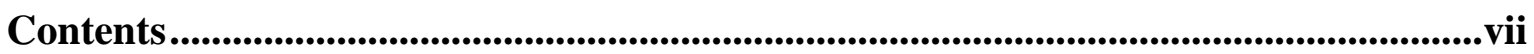

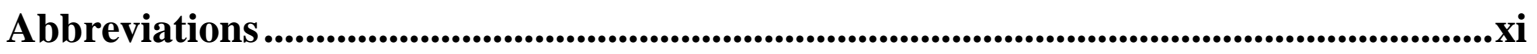

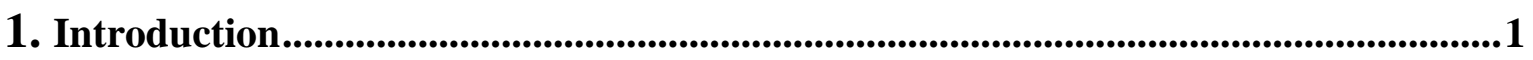

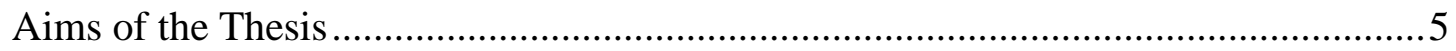

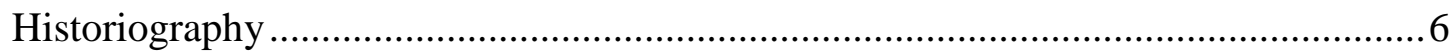

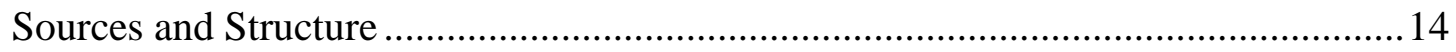

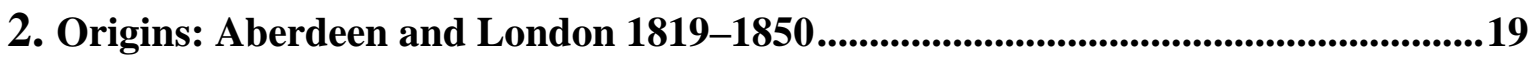

The Free Church of Scotland Settlement at Otago .................................................2 28

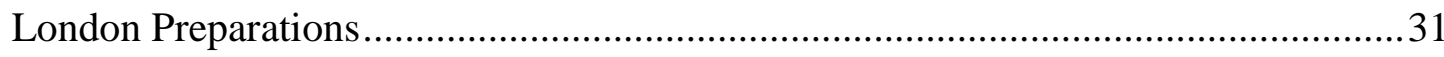

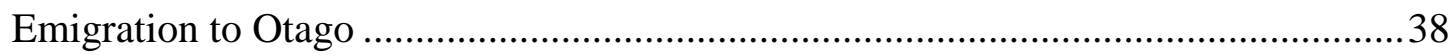

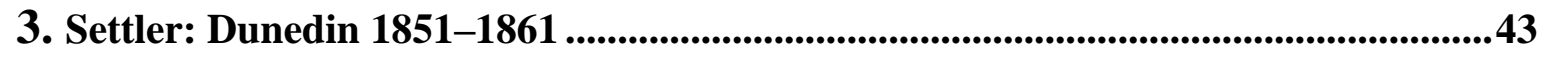

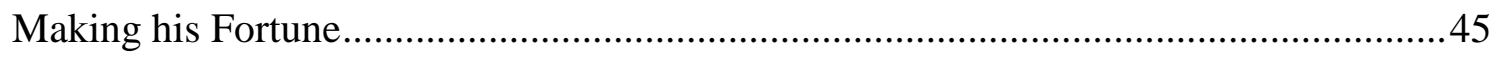

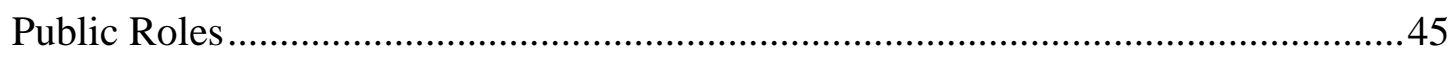

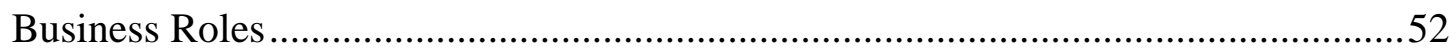

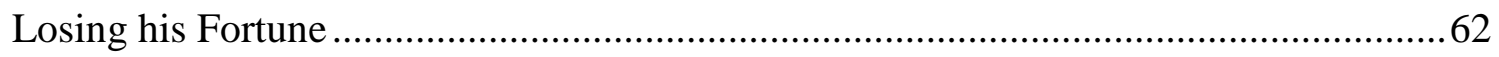

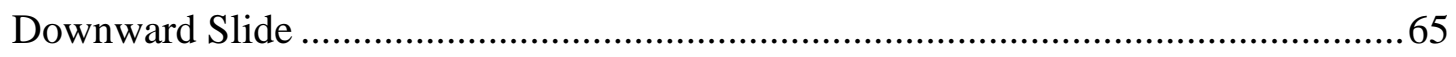

4. Politician: First Career 1852-1861 ...............................................................................73

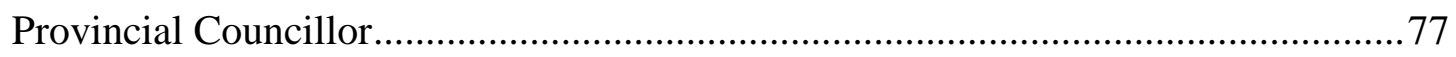

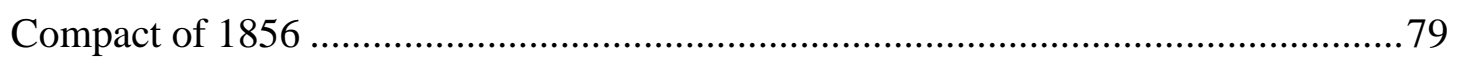

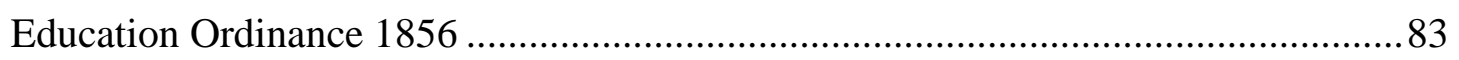

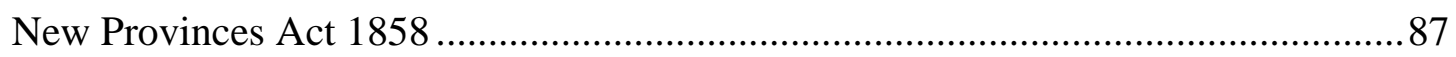

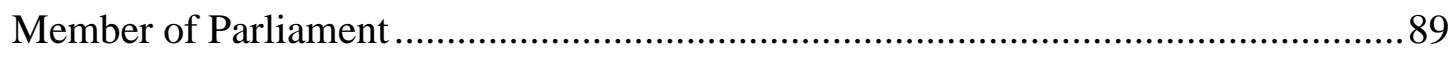

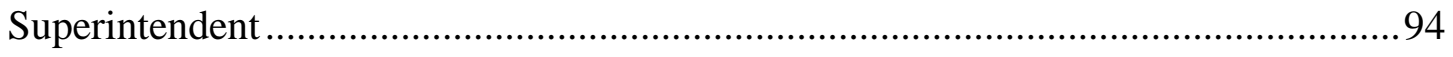



5. Politician: Second Career 1863-1876 Otago ..............................................................105

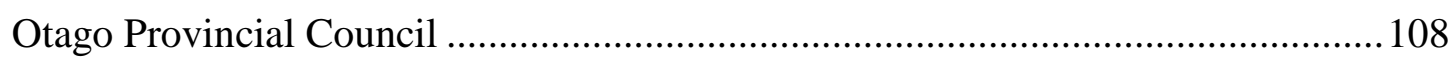

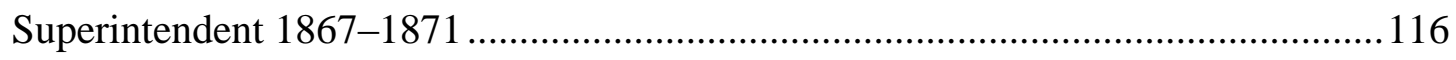

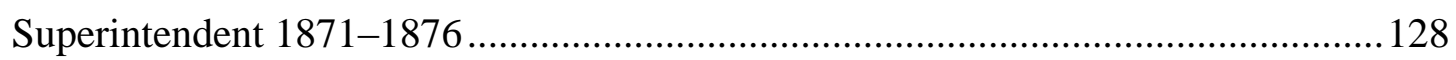

6. Politician: Second Career 1863-1876 Wellington.......................................................141

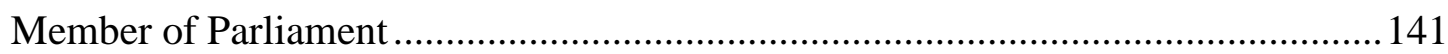

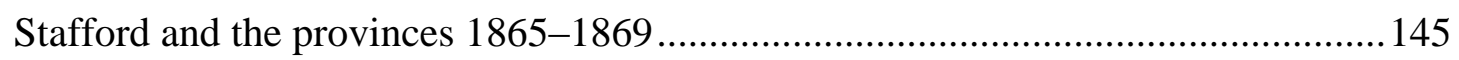

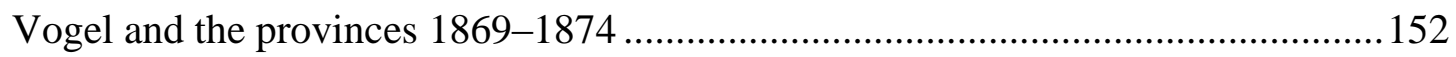

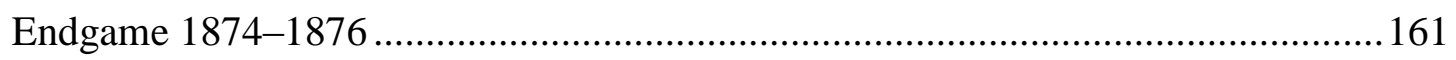

7. Politician: Ministerial Career 1877-1879 _.................................................................173

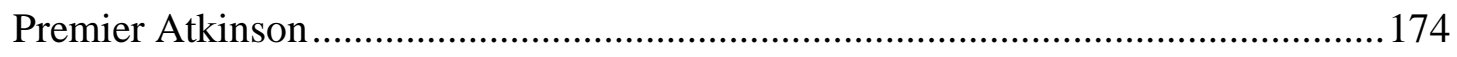

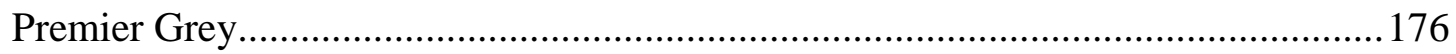

The Hon. James Macandrew, Minister of the Crown .....................................................181

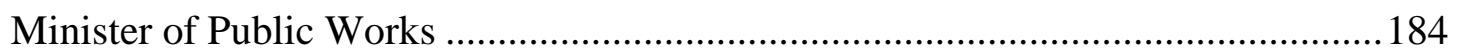

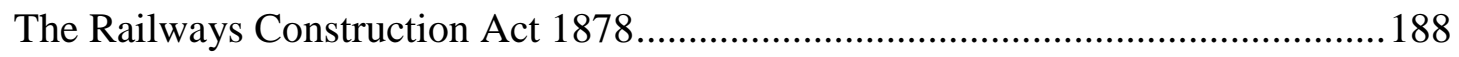

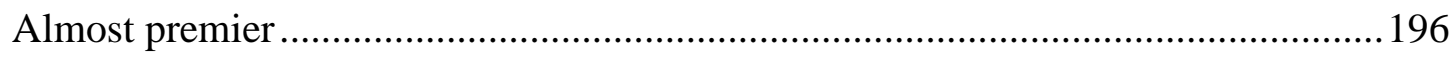

8. Epilogue and Conclusion 1879-1887 ..............................................................................203

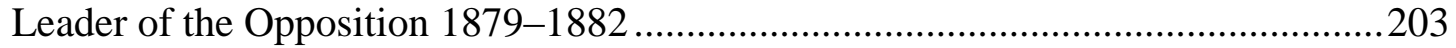

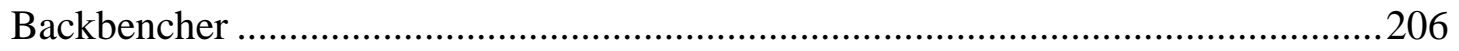

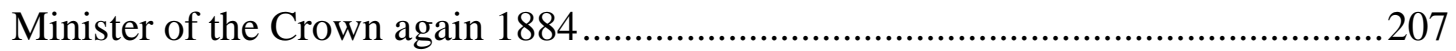

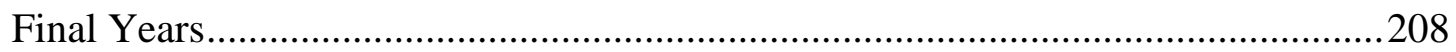

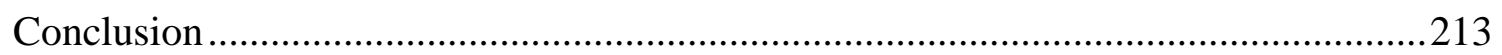

Bibliography ..................................................................................................................................221 



\section{AbBreviations}

AJHR

ANZ

ATL

CB

CMG

EP

GCMG

GOC

GRA

HL

KWMSS Kate Wilson Manuscript Collection of Macandrew Family Correspondence $\mathrm{JP}$

$\mathrm{KB}$

$\mathrm{KCB}$

KCMG

LC

MHR

MLC

$\mathrm{NE}$

NLS

NOT

NZPD

ODT

OW

PC

ST

TT

$\mathrm{V} \& \mathrm{P}, \mathrm{OPC}$

WCT

WI

Appendices to the Journals of the House of Representatives

Archives New Zealand

Alexander Turnbull Library

Companion of the Order of the Bath Companion of the Order of St. Michael and St. George Evening Post Knight Grand Cross of the Order of St. Michael and St George General Officer Commanding Grey River Argus Hocken Library Justice of the Peace Knight Bachelor Knight Commander of the Order of the Bath Knight Commander of the Order of St. Michael and St George Legislative Council Member of the House of Representatives Member of the Legislative Council Nelson Examiner National Library of Scotland North Otago Times New Zealand Parliamentary Debates Otago Daily Times Otago Witness Provincial Council/Privy Councillor Southland Times Tuapeka Times Votes and Proceedings, Otago Provincial Council West Coast Times Wellington Independent 



\section{CHAPTER 1}

\section{INTRODUCTION}

When James Macandrew landed on the Dunedin foreshore in 1851, the scrabbling village was home to 1455 Europeans whose livelihoods centred on Princes Street, the muddy thoroughfare running south from the dominating Bell Hill. ${ }^{1}$ When he died in 1887, Dunedin had 45,514 European residents and was the second city of New Zealand. ${ }^{2}$ Dunedin's streets had been paved by gold and Bell Hill had been lowered by fourteen metres. The city boasted substantial civic buildings, including stone churches and a university, factories, steam trams, a cable car to access the spreading hill suburbs and a ferry service reached Macandrew's harbour-side home.

On Macandrew's arrival in New Zealand, the Dependency was a Crown Colony administered by a Governor-in-Chief, Captain George Grey, and the 1600 km-long country was home to 26,707 Europeans who lived in six isolated settlements accessible most easily by sea. ${ }^{3}$ By 1887 the European population had mushroomed to 603,361 and the country was united by 2817 kilometres of railways. A provincial system of government had been superseded by a centralised New Zealand administration and Macandrew had served for two years in a Grey Cabinet. ${ }^{4}$ The country had been transformed by the explosive growth created by a population increase of $2260 \%$ in the thirty-six years after Macandrew's arrival: in this period, he was rarely still. He was at times a businessman and a landowner, a churchman and a family man, a stalwart of his community and a life-long politician who occupied virtually all the elective positions available in local, provincial and colonial politics. His fortune multiplied to considerable proportions then plummeted to insolvency. He was a booster and a bankrupt. He embraced self-help and he championed stateintervention. He was socially conventional and a drinker. His life was based on a set of conservative social values but his behaviour, at times, was unpredictable and inconsistent.

Otago historian Tom Brooking has suggested that along with Edward Gibbon Wakefield and Julius Vogel, Macandrew was one of the three great optimists of the nineteenth-century Pakeha world. ${ }^{5}$ He was able to persuade others to apply technology to

\footnotetext{
${ }^{1}$ Otago Witness, 8 March 1851.

${ }^{2}$ Otago Daily Times, 29 April 1887. Auckland had a population of 57,048.

${ }^{3}$ Registrar-General of New Zealand, Statistics of New Zealand for 1853, 1854, 1855, and 1856, Auckland, 1858 , p. iv.

${ }^{4}$ Registrar-General of New Zealand, Statistics of New Zealand for the Year of 1887, Auckland, 1888. Population, p. 3; Railways, p. 260.

${ }^{5}$ Tom Brooking: speech to Rich and Macandrew Families descendants, 15 February 2001, Dunedin.
} 
the development of New Zealand, and was in a position to spend public money to do so. Initially, as a Provincial Councillor and Member of Parliament, then as Superintendent of Otago and later, as Minister of Public Works, he facilitated the construction of much of New Zealand's infrastructure-public buildings including the university in Dunedin, new settlements in Otago and railways throughout both islands. His influence lives on in Parliament and in many aspects of New Zealand society, yet today few New Zealanders know of him.

An 1887 obituarist in the Southland Times, a publication which had been unremittingly critical of James Macandrew for most of his career, wrote: 'There are some politicians who are always in office and others who are always in power-which is quite a different thing. Mr Macandrew belonged essentially to the latter class. He was in office for many years, but he was in power from the time he landed in Otago nearly forty years ago, until he met his death at his own door, the day before yesterday. ${ }^{6}$ Macandrew's was a household name in New Zealand for more than thirty-five years, and at times he featured in the Colony's newspapers virtually every day, either celebrated and feted, or reviled and repudiated.

There are conflicting assessments of James Macandrew's character and behaviour. One claimed that 'It has almost passed into a proverb that Otago is Macandrew and Macandrew is Otago. So much has he been associated with almost every important event, and connected with every institution, that no history of the province would be correct or complete without his name being brought prominently and repeatedly to the front., 7 Thomas Bracken called him 'a leader staunch and true, ${ }^{8}$ but others have described Macandrew as 'an ultra-provincialist," "whose cool audacity was matched only by his political opportunism;' 10 as a man who demonstrated 'the most marked exhibitions of imprudence, ${ }^{11}$ and he was known by some as 'Slippery Jim. ${ }^{12}$ Another historian argues

\footnotetext{
${ }^{6}$ Southland Times, 3 March 1887.

${ }^{7}$ Otago, Southland and South Canterbury Provincial Almanac \& Directory (1875-1909), 'Sketch of the Life of James Macandrew', Dunedin, Mills, Dick \& Co., 1886, p. 2.

${ }^{8}$ Thomas Bracken, Musings in Maoriland, Dunedin, Arthur T. Keirle, 1890, p. 323.

${ }^{9}$ W.P. Morrell, The Provincial System in New Zealand: 1852-76, $2^{\text {nd }}$ ed., Christchurch, Whitcombe \& Tombs, 1964, pp. 157, 168.

10 A.H. McLintock, The History of Otago, Dunedin, Otago Centennial Historical Publications, 1949, reprinted, Christchurch, Capper Press, 1975, p. 495.

${ }^{11}$ David Hall, 'MACANDREW, James', from An Encyclopaedia of New Zealand, edited by A.H. McLintock, originally published in 1966, Te Ara - The Encyclopedia of New Zealand, updated 18-Sep-2007. http://www.TeAra.govt.nz/1966/M/MacandrewJames/en.

${ }_{12}$ Stuart W. Greif and Hardwicke Knight, Cutten: Letters Revealing the Life and Times of William Henry Cutten the Forgotten Pioneer, Dunedin, Stuart Greif and Hardwicke Knight, 1979, p. 73.
} 
that 'Macandrew...was a gambler and speculator...impulsive, at times reckless.' ${ }^{13}$ As Macandrew's fortunes waxed and waned, his status moved from leader to outcast, from eminent to ordinary-the title of this thesis uses two descriptions and assesses their accuracy.

Macandrew was a fiscal conservative on his arrival in Dunedin, a community founded on self-sufficiency, and he was convinced that a larger population would stimulate faster growth in this undeveloped country. In the absence of private investors with the capital to build the province's infrastructure, he modified his views on self-reliance and quickly came to support the use of state resources to build roads, railways, harbours and more. Few of the judgements on him acknowledge his contribution to social conditions in the colony but as the economy stumbled, he recognised that the state would also need to assist individuals and he became a proponent of deferred payment for land and state loans to settlers. He eventually suggested that unemployed colonists be given free land to enable them to be self-supporting.

He was born, raised and entered the commercial world as an apprentice clerk in Aberdeen. He moved to London in 1838 and by 1845 was a partner in Garden and Macandrew, Iron and Steel Merchants. He was active from 1845 in the London Branch of the Lay Association of the Free Church of Scotland (later the Otago Association), decided against emigration in 1847, married Eliza Reynolds in 1848 and migrated to New Zealand in 1850. On arrival in Dunedin Macandrew was thirty-one years old and until his death at the age of sixty-seven he served God, mammon and the public of New Zealand, as a member of the Dunedin Town Board, Otago Provincial Councillor, Superintendent of that Province, Member of the House of Representatives, Minister of the Crown, leader of his parliamentary faction and almost Premier. ${ }^{14}$

During the 1850s he was twice accused of using Provincial funds for his own purposes even though he was a prosperous businessman managing (in contemporary terms) a multimillion dollar trading operation. ${ }^{15} \mathrm{He}$ was declared bankrupt and jailed in 1861 but he recovered from this disgrace to become the leading Otago provincial politician for ten years. He sat in the General Assembly for over thirty years but as a Minister of the Crown

\footnotetext{
${ }^{13}$ Erik Olssen, A History of Otago, Dunedin, John McIndoe, 1984, p. 48.

${ }^{14}$ Hall, 'MACANDREW, James'. http://www.TeAra.govt.nz/1966/M/MacandrewJames/en.

${ }^{15}$ McLintock, Otago, pp. 399 \& 436; Olssen, Otago, p. 46, 'In 1857...Macandrew's Melbourne steamer made a profit of $£ 1,200$ each monthly trip.' P. 49, in 1861 'his speculations had lost him some $£ 40,000$.' These amounts are \$131,000 and \$4,388,000 approximately, in 2012 dollars, using the Reserve Bank of New Zealand CPI Inflation Calculator, http://www.rbnz.govt.nz/statistics/0135595.html.
} 
in 1879 , he was still considered to be reckless in the extreme. ${ }^{16}$ Unusually for the nineteenth-century, he became a full time politician and spent thirty-four years of his life in public service. He was a member of the Otago Provincial Council for twenty-two of its twenty-four years, and was one of the longest serving Members of the House of Representatives. At his death in 1887, he was the only survivor of the first Parliament which met in Auckland in $1854 .^{17}$

Throughout his life, Macandrew was closely associated with original thinkers and unconventional politicians - with the Wakefields in the 1840s and 1850s, with Vogel in the 1860s and with Grey in the 1870s. Macandrew was prepared to support their challenges to the accepted order. He accepted power with them and eventually, parted from them all; but he rarely emerged as an original thinker and leader. He was persevering and had long careers in both legislatures but it was only in Otago, with its cohesive and usually supportive populace, its immense natural resources which funded costly infrastructure projects and its siege mentality provoked by the marginalisation of the provinces, that he could be considered a successful leader. In national politics, although influential in the House, he lacked nationwide appeal and as Leader of the Opposition, he was unable to unite a caucus of disparate personalities.

Serving at both provincial and colonial levels of government was de rigueur for a small group of the colony's original settlers: fourteen of the seventeen nineteenth-century Premiers were Provincial Councillors and four of these were Superintendents. ${ }^{18}$ Macandrew's long service in both tiers of government meant his several political roles were inevitably linked and he served in most of the positions available on the Otago Provincial Council as well as sitting in the first nine Parliaments. ${ }^{19}$ In the manner of the day he used each platform to promote the other and once the provinces were discarded, he

\footnotetext{
${ }^{16}$ Raewyn Dalziel, Julius Vogel: Business Politician, Auckland, Auckland University Press, 1986, p. 230.

${ }^{17}$ Otago, Southland and South Canterbury Provincial Almanac \& Directory (1875-1909), p. 4, '...he now holds the position of being father of the House'; Bracken, p. 323, includes a thirteen verse eulogy entitled JAMES MACANDREW, the 'Father of the House'.

${ }^{18}$ Guy Scholefield, New Zealand Parliamentary Record, Wellington, Government Printer, 1950. Premiers Fitzgerald, Grey, Stafford and Whitaker were Superintendents while Atkinson, Domett, Forsaith, Fox, Hall, Pollen, Seddon, Sewell, Stout and Vogel were Provincial Councillors. 38 (86\%) of the total 44 Provincial Superintendents were either MHR or MLC ( 8 were in both) at some stage of their political careers-33 served at provincial and colonial levels simultaneously.

${ }^{19}$ Ibid., p. 121.

James Macandrew, 1819-87, businessman, Member OPC 1853-59, 1863-67, Speaker OPC 1853-54, 185659, Otago Executive Council 1854, Otago Superintendent 1860-61, 1867-76, MHR 1853-60, 1865-87, Secretary for Crown Lands and Minister of Immigration 1877-78, Minister of Public Works 1878-79 (Grey Ministry), Minister of Lands, Immigration and Mines (Stout-Vogel Ministry) 1884.
} 
remained an outspoken advocate for Otago while both a backbencher and a minister in the House of Representatives.

\section{AIMS OF THE THESIS}

Macandrew was active in virtually all of New Zealand's political institutions during his four decades of public life and interacted with most of the country's movers and shakers. His many-faceted life in Dunedin, his involvement in a wide range of commercial activities, his lengthy career in public service, his extended Parliamentary service, combined with his short ministerial career, and his presence at so many important events in New Zealand's history makes him a subject worthy of his own biography. As a middleclass, Scottish, Free Church immigrant, the story of Macandrew's life provides a distinctive lens through which to view a rapidly-changing and important period of New Zealand history. His biography will explore what it meant to be a businessman and a politician in the settler society of New Zealand. This thesis is a study of the life of a man who polarised onlookers, who engendered intense loyalty and powerful enmity in his fellow citizens while making significant contributions to the governance and development of his adopted country. Published accounts of his activities, chiefly in newspapers, lean to flattery or censure - this thesis will strive for a balanced assessment.

The first tier of colonial, nineteenth-century politicians is well represented in New Zealand historiography. Ten of the nineteenth-century Premiers have their biographersFitzgerald, Stafford, Weld, Vogel, Atkinson, Grey, Hall, Stout, Ballance and Seddon-but less interest has been taken in the contributions made by provincial leaders-Fitzgerald, Stafford and Grey served as Superintendents but only four more of the forty four Superintendents, Campbell, McLean, Rolleston and Cargill, have had their biographies published. This study provides a view of New Zealand from the second tier, the provincial periphery, and firmly places Macandrew as a politician who used the General Assembly to enhance the position of his province.

The intentions of the British Government that were encapsulated in the Constitution Act 1852 and the role of the Provinces in the government of New Zealand form a major part of this thesis. It assesses the Act's interpretation by Governor George Grey and its impact on the New Zealand settlers. It explores the manner of the provinces' passing and their legacy. W. P. Morrell has suggested that a lack of similarity in the Provinces' circumstances, and a lack of co-operation between central and local 
governments, led to their demise. He claimed that 'the financial problems of provincialism were felt to be insoluble' and 'the simplest and most "practical" solution of the financial problem was to abolish the provinces, and the provinces were abolished accordingly. ${ }^{20}$ However, the actions of ambitious and frustrated politicians also made a contribution to their demise and Macandrew's part, as an outspoken leader of a substantial provincialist party, may have been greater than previously recognised. This thesis assesses Macandrew's role in the life of the provinces, considers what other forces were at play and asks whether Morrell's explanation is sufficient.

\section{HiSTORIOGRAPHY}

The major historians of Otago-McLintock, Morrell and Olssen-provide an overview and some trenchant criticisms of Macandrew's activities. McLintock's is the most exhaustive study of Otago to 1950, and he devotes as much space to Macandrew as he does to any other individual. Macandrew is frequently the object of McLintock's disapproval but he does admit that 'politically, the period 1863-76 is Macandrew's...Macandrew rose superior to adversity and, by sheer strength of personality, became the foremost politician of his province and almost, one might say, of the colony. ${ }^{21}$ McLintock lists Macandrew's strengths and failings: 'no one rivalled Macandrew's sheer mastery of men which, with him, might be regarded as a consummate art.' McLintock continues: 'granted that he was narrow and dogmatic to an insufferable degree, he had, by way of compensation, the unquenchable courage of his convictions, an unsurpassed faith in himself and his destiny, and above all, an almost incredible tenacity of purpose...the thought of failure was foreign to his nature' but McLintock's final judgment of Macandrew is ambivalent, damning him with faint praise: 'Almost paradoxically, therefore, his narrow-minded parochialism, his smug dogmatism, his irritating self-assurance and blatant effrontery, were so often shot through with flashes of statesmanlike foresight that one is left wondering if Macandrew possessed also the spark of genius. ${ }^{22}$ McLintock does not appreciate the emotional Macandrew, claiming that 'Characteristically, Macandrew made his appeal to the heart and not the intellect....But when the fire of Macandrew's eloquence had died and the embers were raked, little of any value remained.' McLintock appears reluctant to acknowledge that Macandrew, whose weaknesses he describes in

\footnotetext{
${ }^{20}$ Morrell, The Provincial System, p. 285.

${ }^{21}$ McLintock, Otago, p. 623.

${ }^{22}$ Ibid., p. 624.
} 
painstaking detail, was a charismatic politician who had a disproportionately large influence on the forces shaping New Zealand as European settlement expanded. ${ }^{23}$

Morrell similarly damns Macandrew with faint praise. He acknowledges Macandrew's major role in the preservation of the provinces but he makes few constructive comments. To Morrell, Macandrew was an ultra-provincialist and the employer of 'irregular proceedings', and his description, 'the energetic and self-confident Macandrew' is a term of disparagement. ${ }^{24}$ Olssen judges Macandrew severely, and uses expressions such as 'typical impetuosity...the superintendent's dizzy dreams and giddy rhetoric....The rest of his political life exhibited the same mixture of visionary dreams, considerable achievement and frequent failure...saw him as reckless in the extreme. ${ }^{25} \mathrm{He}$ gives Macandrew small credit for the successful building of much of Otago's infrastructure, nor for his liberal values and his concern for the wellbeing of struggling settlers. The disparaging depictions of Macandrew by these three historians may have discouraged further interest in his life. A thesis about Macandrew was presented for an Otago MA in 1926 but no items on the wider aspects of his life have appeared in available historical writings. ${ }^{26}$

Before considering Macandrew's achievements, it is necessary to examine the environment that shaped him. Macandrew was an upwardly-mobile Scotsman whose world view and values were shaped by his Aberdeen childhood and his London residency so it is important to consider the middle-class milieu of middle nineteenth-century Britain in which he was raised. It is also appropriate to identify the influence of the Scots in New Zealand to better understand his behaviour.

Raised from the age of six by a widowed and impecunious mother, Macandrew was fortunate to have relatives who encouraged and supported his ambitions. Surviving letters from uncles and cousins emphasise the importance of the extended family at this time and the need for self-reliance. Scottish migration was commonplace, and his move to London, and to New Zealand, followed a well-beaten track-Scottish migration was 'sustained without interruption not only over decades and generations but across centuries',

\footnotetext{
${ }^{23}$ Ibid., p. 595.

${ }^{24}$ Morrell, The Provincial System, pp. $131 \& 190$.

${ }^{25}$ Erik Olssen, 2007, 'Macandrew, James 1819?-1887', Dictionary of New Zealand Biography, updated 22 June 2007, http://www.dnzb.govt.nz/.

${ }^{26}$ M.A. Ellis, James Macandrew and His Times, MA thesis, University of Otago, Dunedin, 1926.
} 
and had a major impact on the new world. ${ }^{27}$ Arthur Herman, like many others, claims that the legacy of the Scottish Enlightenment, with its emphasis on literacy and democracy, meant that Scots had a disproportionate impact on the world: they were educated, pragmatic individuals driven from an impoverished homeland to seek their fortunes worldwide. ${ }^{28}$ Emigration was seen in a positive light as the pursuit of opportunities not available at home and according to Marjory Harper, was a safety valve, reducing the population and pressure on the economy. ${ }^{29}$ Harper estimates that between 1825 and 1914 , 1,841,534 Scots sailed to non-European destinations with $25 \%$ bound for Australasia, a huge outpouring from a small country whose total population in 1911 was less than five million. New Zealand was a popular destination. In 1871, Scots comprised $10 \%$ of the UK population, while in New Zealand they comprised $27.3 \%$ of the UK-born population, a disproportionate representation. ${ }^{30}$ Lowlanders were over $80 \%$ of this group and were seen as 'archetypically egalitarian, competent, undemonstrative and somewhat dour', and considered by some historians to be the prototype of the emerging New Zealander. ${ }^{31}$ Macandrew stood out in this crowd: he was a Highlander, recusant, well read, had some capital and enjoyed membership of the New Zealand elite until he over-reached his resources and skills.

Belich considers that 'outside Scotland itself, there probably is no other country in the world in which Scots had more influence' but the story of the Scots in New Zealand was generally confined to local histories until 2000. ${ }^{32}$ Gilbert Pearce's history The Scots of New Zealand published in 1976 was typical of this genre. ${ }^{33}$ Two sub-groups of Scots who maintained their own distinctive lifestyles have been studied in depth: a group of Highlanders settled north of Auckland after a false start in Canada and a large number of Shetland Islanders arrived from 1870 onwards. ${ }^{34}$ In 1985 Brooking noted the absence of an adequate database for an 'authoritative assessment of the Scots' contribution to economic

${ }^{27}$ Tom Devine, To the Ends of the Earth: Scotland's Global Diaspora, 1750-2010, London, Penguin, 2012, p. 289.

${ }_{28}$ Arthur Herman, How the Scots Invented the Modern World, New York, Crown Publishers, 2001.

${ }^{29}$ Marjory Harper, Adventurers and Exiles: The Great Scottish Exodus, London, Profile, 2003, p. 3.

${ }^{30}$ Jock Phillips \& Terry Hearn, Settlers: New Zealand Immigrants from England, Ireland \& Scotland 18001945, Auckland, Auckland University Press, 2008, p. 53, Table 4. The data is from the 1871 New Zealand Census.

${ }^{31}$ James Belich, Paradise Reforged: A History of the New Zealanders from the 1880s to the Year 2000, Auckland, Allen Lane, 2001, p. 221; Marjory Harper, 'A Century of Scottish Emigration to New Zealand', Immigrants \& Minorities, 29:2, 2011, p. 222 estimates 75\% of the Scots were Lowlanders.

${ }^{32}$ Belich, Paradise Reforged, p. 221.

${ }^{33}$ G.L. Pearce, The Scots of New Zealand, Auckland, Collins, 1976.

${ }^{34}$ Neil Robinson, To the ends of the earth: Norman McLeod and the Highlanders' migration to Nova Scotia and New Zealand, Auckland, HarperCollins, 1997; Susan and Graham Butterworth, Chips off the Auld Rock: Shetlanders in New Zealand, Wellington, Shetland Society of Wellington, 1997. 
or social or political development in New Zealand' but recognised the 'distinctive Scots approach to national development. ${ }^{35}$ He also acknowledged their drive for a more just and equitable society than the one they had left.

In 2002 a scholarly overview, The Heather and the Fern, appeared which summarised the influence of Scots on New Zealand culture. ${ }^{36}$ In it, Angela McCarthy writes that migration in the nineteenth century was driven by the need to escape depression at home, find new opportunities for themselves and their families, engage in an adventure and take advantage of family links in the new country. ${ }^{37}$ Rosalind McClean considers that Scottish women 'were generally more reluctant migrants than their menfolk. Once committed to the enterprise, however, females went on to make vital contributions to the building of communities and tended to act as the bearers of the cultural flame, even if they married "out." ${ }^{38}$ Scots prospered in the British Empire which offered opportunities unavailable in Scotland and most, especially the Lowlanders, went voluntarily and enthusiastically. While there were some instances of brutal clearance of communities, many Highlanders also left willingly. However, Peter Matheson, without acknowledging the financial imperative which existed for many migrants, suggests that the expanded living space and the added opportunities to better themselves elsewhere, did not overcome a sense of intense marginalisation at their destinations and claims that they saw themselves as liberals, not in our modern sense of the word, but as people committed to meritocratic principles, to education and self-discipline. ${ }^{39}$ These views made them a distinct minority of outsiders in their new world but Tom Brooking submits that the Scots made a distinctive contribution to New Zealand's life, because they were more egalitarian than other settlers, notably in their gender and social relations. ${ }^{40} \mathrm{Jim}$ McAloon concludes that 'Scottish runholders, financiers, managers, manufacturers and businessmen played a vital role in the development of New Zealand's colonial economy and won success out of proportion to their numbers. ${ }^{41}$

It is only recently that quantitative studies have considered Scottish origins in detail: Phillips and Hearn analysed over 11,800 death certificates to reach their conclusions while

${ }^{35}$ Tom Brooking, “"Tam McCanny and Kitty Clydeside”-The Scots in New Zealand', p. 158, in R.A. Cage, ed., The Scots Abroad: Labour, Capital, Enterprise, 1750-1914, London, Croom Helm, 1985, pp. 156-190.

${ }^{36}$ Tom Brooking and Jennie Coleman, eds., The Heather and the Fern: Scottish Migration \& New Zealand Settlement, Dunedin, University of Otago Press.

${ }^{37}$ Ibid., p. 14.

${ }^{38}$ Ibid., p. 13.

${ }^{39}$ Ibid., p. 12.

${ }^{40}$ Ibid., p. 13.

${ }^{41}$ Ibid. 
the Marsden-funded 'Scottish Migration to New Zealand' project, directed by Brad Patterson and Tom Brooking has generated over a hundred publications. ${ }^{42}$ One such publication is that of Rebecca Lenihan who asked five core questions about the Scottish migrants who arrived in large numbers from 1840: 'from where in Scotland did they come, who came, when, in what numbers and where did they settle?' She found, inter alia, that an almost exact geographical cross-section of Scotland came to New Zealand while also identifying patterns of migration peculiar to the Shetland Islands. ${ }^{43}$

In 2011, further research on Scottish influence on New Zealand society and culture was published in three issues of Immigrants \& Minorities. ${ }^{44}$ These challenge and dispel many of the myths which surround the Scots immigrants - their Highland origins, their victimisation, exceptionalism, clannishness, Puritanism and their radicalism. MacKenzie and Patterson conclude that Scots cannot be seen as some homogeneous entity but are 'as diverse as the geographical regions of Scotland itself, in social and environmental origins, in occupations and pastimes, in cultural affiliations, in educational attainment and in religion. But nonetheless they can be distinguished from the other ethnicities of the British and Hibernian Isles. ${ }^{45}$ The Scots arrived in New Zealand in larger numbers than most other migrant groups, many were well educated, with prior business experience and had capital to sustain them so it is unsurprising that they did well in their adopted country and attracted attention by their success. Tanja Bueltmann has concluded that 'Scots influenced New Zealand culture in a fundamental way. Given that the Scots were early arrivers and eventually represented up to one-quarter of the settler population, they were, then, de facto disproportionately responsible for New Zealand's foundational culture. ${ }^{46}$

The recent growth of literature on settler societies, gathered in James Belich's Replenishing the Earth, provides a context for Macandrew's life as a settler. ${ }^{47}$ Bryan

\footnotetext{
42 Tom Brooking and Brad Patterson, Scottish migration to New Zealand to 1950, and its contribution to the development of New Zealand Society, see website http://www.otago.ac.nz/historyarthistory/research/marsden/scottish_migration.html

${ }^{43}$ Rebecca Lenihan, 'From Alba to Aotearoa: Profiling New Zealand's Scots Migrants, 1840-1920', PhD thesis, Victoria University of Wellington, 2010, pp. iii \& 236.

${ }^{44}$ Immigrants \& Minorities, 29:2, 2011; 29:3, 2011; 30:1, 2012.

45 John MacKenzie \& Brad Patterson, 'The New Zealand Scots in International Perspective: An Introduction', Immigrants \& Minorities, 29:2, 2011, p. 153.

${ }^{46}$ Bueltmann, Tanja, Scottish Ethnicity and the Making of New Zealand Society 1850-1930. Edinburgh, Scottish Historical Review Monographs Series No. 19, Edinburgh University Press, 2011, p. 207. When Macandrew became the $15^{\text {th }}$ New Zealand Superintendent, 5 Englishmen, 5 Irishmen and 5 Scots had held that position but Scottish dominance did not continue as by abolition, of the 44 Superintendents, 12 (27\%) had been Scottish-born while 24 (55\%) were born in England.

${ }^{47}$ James Belich, Replenishing the Earth: The Settler Revolution and the Rise of the Anglo World 1783-1939, Oxford, Oxford University Press, 2009.
} 
Palmer has suggested that a slow evolutionary process began in newly settled territories as expanding numbers of pioneers built first villages, followed by towns, then cities. ${ }^{48}$ Richard Wade, and Belich, take an opposing view, that towns preceded general settlement and argue that towns were the 'spearheads of the frontier', impacting forcefully on the settlement process by providing organisational and support facilities. ${ }^{49}$ Hamer agrees that towns often played a central role in opening up new lands and suggests that the concept of an 'urban frontier' was artificially created and advanced by boosters and journalists who saw land settlement and urbanisation as simultaneous. ${ }^{50}$ Kate Brown describes the booster modus operandi in Montana where 'cities came first, then people' and developers had to attract settlers in order to recoup their investments. She notes that 'booster propaganda lied outright only at times; it usually misled by innuendo and cheerful exaggeration. ${ }^{51}$ In Dunedin, settlers were sold a package of town, urban and rural land to encourage the simultaneous development of town and country but settlement of the hinterland was a slow process, preceded by the time-consuming process of road-building. Macandrew joined the ranks of the boosters by becoming an enthusiastic dealer in land.

Belich suggests that European expansionism in new territories took three successive forms-networks emerged, empires were established and settlement expanded-although these three events did not necessarily occur in every new colony. ${ }^{52}$ He notes that a unique Anglo 'settler revolution' occurred during the nineteenth century when population pressures in Great Britain made emigration acceptable and in many British colonies the phase of expanding settlement usually went through four stagesincremental, explosive, recolonisation, and decolonisation. The 'urban frontier' was an initial feature of the occupation of a new land, when 'incremental colonies faced outwards across the sea to their oldlands; the interior was the back-country' and towns were established as centres for the taming of their interiors. ${ }^{53}$ These were the first introduction of a new race into overseas lands, and subsistence farming was usually the order of the day. Connections with the home country were few and slow and incremental colonies were

${ }^{48}$ Bryan Palmer, in M. Brook Taylor, ed., Canadian History, A Reader's Guide, Vol. 1: Beginnings to Confederation, Toronto, University of Toronto Press, 1994; Doug McCalla, Planting the Province: The Economic History of Upper Canada. Toronto, University of Toronto Press, 1993.

${ }^{49}$ Richard Wade, The Urban Frontier: Pioneer Life in Early Pittsburgh, Cincinnati, Lexington, Louisville, and St. Louis, Chicago, University of Chicago Press, 1976.

${ }^{50}$ David Hamer, New Towns in the New World: Images and Perceptions of the Nineteenth Century Urban Frontier, New York, Columbia University Press, 1990.

${ }^{51}$ Kate Brown, 'Gridded Lives: Why Kazakhstan and Montana are nearly the Same Place', The American Historical Review, 106, No. 1, 2001, p. 33.

${ }_{52}$ Belich, Replenishing the Earth, p. 21.

${ }^{53}$ Ibid., p. 178. 
distinguished from Belich's next, explosive phase of settlement, by the absence of mass transfer 'of people, ideas, money and bulky goods.' 54

Explosive settlement, which generally followed incremental settlement, was often marked by unrepeatable events such as gold strikes, unrestrained export of animal products and the exploitation and exhaustion of virgin land. The explosive phase usually saw dramatic alternations of boom and bust as boosters such as Macandrew talked up their particular region and new settlers flooded in: investors in Britain were regularly beguiled by dreams of endless riches waiting to be extracted from the new settlements, often pouring their money into impossible projects. Growth fed on growth, usually based on unsustainable financial schemes, which inevitably led to economic collapse. Recolonisation, the inflow of further settlers usually followed, as each bust was rescued by successive waves of immigration and investment. As produce was channelled to the sole market, Britain, complete independence from the homeland was postponed. Belich's schema provides the framework for this biography of James Macandrew who arrived in New Zealand at a time of expanding settlement and lived through three of Belich's four phases: incremental, explosive and recolonising settlement. Macandrew saw the endless opportunities offered in New Zealand: he amassed great wealth and lost it but was able to rebound from each failure. His enduring view of New Zealand as 'the Great Britain of the south' inspired his boosterism: his commercial enterprises, his development of shipping and overseas markets made a momentous contribution to the colony's progress through the explosive and recolonising phases of colonisation.

The young Macandrew was shaped by middle class Scotland and England and questions arise: which values did he retain from each culture and how did they shape his life in New Zealand? In his economic history of Leeds, R. J. Morris emphasises the insecurity of the middle class who were 'an immensely privileged group in a society of great inequality', whose lifestyle was based on a cycle of property acquisition and accumulation, with the ever present threats of illness, death and economic ruin. ${ }^{55}$ Concerns with reputation added to their insecurity and the family network was the sole effective agency for spreading risk. Davidoff and Hall also emphasise the unrelenting physical and economic insecurity of the British middle class and note the rigidity of their self-imposed

\footnotetext{
${ }^{54}$ Ibid.

${ }^{55}$ R.J. Morris, Men, Women and Property in England, 1780-1870: A Social and Economic History of Family Strategies Amongst the Leeds Middle Classes, Cambridge, Cambridge University Press, 2005, p. 369-371.
} 
morality. ${ }^{56}$ They trace the emergence of the provincial middle class in England in that period when decades of war, fluctuating trade, social upheaval and a dearth of land impelled families into commercial activity where 'one of the strongest strands binding together urban and rural, nonconformist and Anglican, Whig, Tory and Radical, manufacturer, farmer and professional, wealthy and modest, was the commitment to an imperative moral code and the reworking of their domestic world into a proper setting for its practice.' They note the 'centrality of the sexual division of labour within families for the development of capitalist enterprise.' Stana Nenadic in her study of a middle class sample in Victorian Glasgow describes a similar world ${ }^{57}$ She considers that this group was characterised by 'their collective construction of, and aspiration towards, a series of idealised states of desirable existence that encompassed material life, family, work and community, in the face of a real experience that was often bleak and marked by enormous vicissitudes' and they had an added burden because 'in Scotland there were also those myths and ideal conditions associated with Scottishness, constructed with astonishing creative force in the years following the 1745 rebellion, and especially in the first few decades of the nineteenth century, in order to accommodate the ambiguities of economic and political relationships with England, while maintaining a sense of cultural identity. ${ }^{58}$ But Nenadic suggests that the myth of 'separate spheres' with wife and daughter as leisurely 'angels in the home' was just that, a myth, and many women were significant players in the economic life of their families. Keeping up appearances may have been even more demanding in the north of Great Britain than the south. Gender roles were clearly defined in the Macandrew family and there is no evidence to show that Eliza Macandrew was engaged in her husband's enterprises but she had her own financial resources and kept the family together when he was imprisoned.

Macandrew's first migration was from Scotland to London where he honed his business skills and established himself as an independent businessman, no mean achievement in the Hungry Forties. A drive to improve his position plus the confidence that resulted from marrying into the worldly-wise Reynolds family motivated his

\footnotetext{
${ }^{56}$ Lenore Davidoff and Catherine Hall, Family Fortunes: Men and Women of the English Middle Class, 1780-1850, London, Hutchinson, 1987, p. 13.

${ }^{57}$ Stana Nenadic, 'The Victorian Middle Classes' in W. Hamish Fraser and Irene Maver, eds., Glasgow, Volume II: 1830 to 1912, Manchester, Manchester University Press, 1996, pp. 265-269.

${ }^{58}$ Stana Nenadic, 'The Rise of the Urban Middle Classes' in Tom Devine and Rosalind Mitchison, People and Society in Scotland: Volume I, 1760-1830, Edinburgh, John Donald in association with The Economic and Social History Society of Scotland, 1988, pp. 109-126; Stana Nenadic, 'The Victorian Middle Classes', p. 266.
} 
emigration to New Zealand. He was comfortable in the Scottish settlement of Otago where he prospered in that meritocratic community. He considered his duty and responsibility was to provide the means for individuals to succeed in life, whether through educational facilities, access to land, or the development of communication links. His life story demonstrates that his Scottish upbringing equipped him with valuable skills but they were not the only ones which propelled his success.

\section{SOURCES AND STRUCTURE}

John Elliott has written that 'theory is of less importance for the writing of good history than the ability to enter imaginatively into the life of a society remote in time or place, and produce a plausible explanation of why its inhabitants thought and behaved as they did. ${ }^{59}$ This thesis does not explicitly appeal to any theory: it is my attempt to explain the world inhabited by the nineteenth-century New Zealand colonists by exploring the life of James Macandrew. It deliberately enters the sphere of biography, although 'many are sceptical of the capacity of biography to convey the kind of analytically sophisticated interpretation of the past that academics have long expected. ${ }^{60}$ Biographers may deal with personality and character, but an historian is committed to using a wide range of verifiable evidence, written, oral, and from other disciplines, not simply to tell a life story. The task of biography is 'to deploy the individual in the study of the world outside that individual and to explore how the private informs the public and vice versa., ${ }^{, 61}$

Oral sources can be useful in providing different perspectives on an issue. Using them requires balancing the historical accuracy of a recollection against the meaning of the story, especially when the recollection is not about the interviewee's own life: distortion can skew a memory. On meeting the three family members who owned memorabilia of Macandrew's life, I realised that their memories of their ancestor's distant life were fragmented and lacked the wider context which would give meaning to their stories and permit verification of events. There are no survivors of Macandrew's era alive to interview, there are few people who know anything of him and he died before the advent of recording devices so there are no physical records of his life beyond the printed word. For these reasons I decided not to use descendants' memories in this thesis. Accordingly, because of the limited amount of information available on Macandrew's private life, this thesis is,

\footnotetext{
${ }^{59}$ J.H. Elliott, History in the Making, New Haven, Yale University Press, 2012, p. xi.

${ }^{60}$ Robert Schneider, p. 573, in Nasaw, David, 'Introduction: Historians and Biography', American Historical Review, 114, No. 3, 2009, pp. 573-578.

${ }^{61}$ Ibid.
} 
necessarily, a study of his public life and focuses on his performance in the commercial and political arenas. The thesis uses printed sources, predominantly, to chronicle Macandrew' life, and minimal speculation to explain Macandrew's character and motivations, reserving a more imaginative version for later, public consumption.

Macandrew spent most of his life in the public spotlight so a large collection of newspaper reporting on his activities is available. A collection of personal papers, so vital to middle-class biography to explain his private life and to understand what motivated him, is absent which may well explain why he has been overlooked. As he has no substantial biographer, public records and the private views of his contemporaries provide the material for this thesis. Newspapers are a major source of information and this thesis relies heavily on Papers Past while the New Zealand Parliamentary Debates and Votes and Proceedings of the Otago Provincial Council have proved invaluable. ${ }^{62}$ A wide range of newspapers were used, some virulently critical of Macandrew, some totally supportive of his actions as well as a few which offered objective commentary: with this variety of observation available, it was possible to make an independent judgment of most of his behaviour.

Denis Le Cren, in his family history of the Rich and Macandrew families, has provided a valuable summary of Macandrew's life. ${ }^{63}$ Ms Kate Wilson of Middlemarch, a great-grand-daughter of Macandrew, made available her collection of Macandrew family papers and Charles Waddy, a descendant of William Hunter Reynolds, Macandrew's brother-in-law, lent me his unpublished history of the Reynolds family. The National Library of Scotland holds some Garden and Macandrew correspondence written by Macandrew. The Hocken Library in Dunedin holds papers of the Otago Lay Association and several of Macandrew's personal items, while the Otago Settlers Museum holds another small collection of personal items. Archives New Zealand in Dunedin holds James' and Eliza's wills and a number of Macandrew's business papers while Archives New Zealand in Wellington hold Governors' Despatches to and from the Colonial Office. The Alexander Turnbull Library contains a valuable trove of papers left by several of Macandrew's political contemporaries.

\footnotetext{
${ }^{62}$ The Kate Wilson MSS Collection includes five letters written by James Macandrew, one to his wife, three to his daughter Mabel and one to his son Hunter and includes his circular business letter advertising the establishment of a trading business in New Zealand. It also includes a number of letters written to Macandrew. The National Library of Scotland holds twenty-three letters dating from 1842 to 1850 relating to Garden \& Macandrew's business activities and includes a copy of the circular letter. The Hocken Library holds a letter from Macandrew to his brother-in-law Thomas Reynolds, papers of the Otago Lay Association, the Otago Settlers Association, and James Hector's letters.

${ }^{63}$ Denis Le Cren, The Rich and Macandrew Families 1280—1993, Nelson, Denis Le Cren, 1993.
} 
Macandrew was 67 when he died, having lived through four decades of the early European settlement of New Zealand, and the eight chapters of the thesis are based on the major roles he played during this time. Although many of his roles overlapped, I have chosen to disentangle them and examine each one separately to tell his life story. This biography is broadly chronological. It describes Macandrew's early life in Great Britain and his first decade as a settler in New Zealand, then focuses on his political activities during three distinct periods of New Zealand history-the establishment of selfgovernment, the abolition of provincial government, and the election of the country's first liberal government.

Chapter two examines Macandrew's formative years from 1819 to 1850, including his education, the launching of his business career and the establishment of his family. It examines his life in London during the 1840s, his business activities, his involvement with the Free Church Settlers of Otago and his migration to Dunedin.

Chapter three examines Macandrew's life in Dunedin in the 1850 s as a Scottish, Free Church, middle-class settler in a new colony. It examines his career as a businessman in Dunedin in the 1850s and the events which led to his imprisonment for bankruptcy.

Chapter four focuses on Macandrew's career as an emerging provincial and colonial politician in the 1850 s, when elected government was established in New Zealand and the responsibilities of provincial and central government were negotiated. This career ended with his dismissal as Superintendent of Otago.

Chapter five examines Macandrew's second career as a politician in the 1860s and 1870s when he returned to public office at both levels of government. It examines his life as a provincial politician who was eventually unsuccessful in preventing the abolition of the provinces in 1876 .

Chapter six also focuses on Macandrew's second political career and examines his role as a member of parliament in the abolition debates.

Chapter seven considers Macandrew's third political career in the 1870s and 1880s, as a member of the House of Representatives, a Minister in Sir George Grey's government and as leader of his parliamentary party.

Chapter eight presents his final years in politics and weaves the strands of his life together to evaluate his legacy in New Zealand. 
The thesis will demonstrate that Macandrew made important contributions to the governance and development of New Zealand and while historians have described him as a conservative, Scottish, Presbyterian bankrupt of little importance, his life story shows he was a politician whose endeavours evolved to meet the needs of successive waves of migrants and who contributed much to his country's social and physical fabric. 



\section{ChaPTER 2}

\section{ORIGINS: ABERDEEN AND LONDON 1819-1850}

When James Macandrew arrived in Dunedin he was a 31-year old family man and an experienced businessman, fresh from living and working for twelve years in the capital of the British Empire with its extensive commercial opportunities. His life over the next decade, until his imprisonment as a bankrupt, is a remarkable tale of unwavering faith in his own judgment, of challenges to the established order, of risk taking, of undreamed financial success and utter failure, and a determination to shape the new colony in his own image. He was the very model of the 'merchant adventurer, [the] commercial entrepreneur' who built the British Empire. ${ }^{1}$ It is pertinent to ask what childhood experiences and later events shaped the man, his character and his moral code.

Macandrew was a product of the distinctive Scottish world of the early nineteenth century-he was born four years after the end of the Napoleonic Wars, into the social and economic upheaval left in their wake. It was a world shaped by the Scottish Enlightenment, the major cultural shift of the previous century when the humanist and rationalist tenets of the European Enlightenment were adopted by Scottish thinkers who rejected authority which was not justified by reason. Scottish intellectual activity was distinguished by its emphasis on empiricism and its determination to improve the life of the individual as well as improving society. Erik Olssen contends that 'the main themes of the Enlightenment were fairly constant-liberalism, rationalism, naturalism, empiricism, and materialism....the central principles of social engineering. ${ }^{, 2}$ In 1750 these, combined with a Presbyterian emphasis on individual salvation based on the teachings of the bible which required individual study, produced a Scottish male literacy rate of almost 75\%, compared with 53\% in England. ${ }^{3}$ An outcome of the Act for Setting Schools 1696 was the establishment of a school in every parish and a rapid growth in libraries where works such as The American Declaration of Independence, Adam Smith's Wealth of Nations, Edward Gibbon's Decline and Fall of the Roman Empire, and Jeremy Bentham's Fragment on Government, all published in 1776, were available. An avid reader all his life, Macandrew is likely to have read and been shaped by some these books and by the discussions

\footnotetext{
${ }^{1}$ John Dunmore, Wild Cards: Eccentric Characters from New Zealand's Past, Auckland, New Holland (NZ) Ltd, 2006, p. 34.

${ }^{2}$ Erik Olssen, 'Mr. Wakefield and New Zealand as an Experiment in Post-Enlightenment Experimental Practice', The New Zealand Journal of History 31, 1997, No. 2, pp. 197-218.

${ }^{3}$ Arthur Herman, How the Scots Invented the Modern World, New York, Crown Publishers, 2001, p. 19.
} 
stimulated by them. ${ }^{4}$ His upbringing imparted a set of values that underlay his conduct throughout his life, so that Macandrew's behaviour was consistent. He believed that an individual was responsible for his relationship with his God and for his own success in life. He believed that society could and must be improved wherever possible, to allow opportunities for everyone to advance themselves.

Denis Le Cren records that Macandrew's father Colin Macandrew was born in 1794 and died in $1825 .^{5}$ Macandrew's family originated in the Black Isle, northeast of Inverness, where his family is commemorated on a gravestone in the grounds of Fortrose Cathedral. ${ }^{6}$ Colin's occupation was listed as Shoemaker in Macandrew's baptismal record but on Macandrew's marriage certificate he became a Leather Merchant: no other information about Colin was located. ${ }^{7}$ Le Cren identifies Macandrew's mother as Barbara Johnson, born about 1790, who died in 1873 and whose life is similarly unrecorded.

Details of Macandrew's life as a child in Scotland and as a man in England are sparse and personal details reported in some accounts of his life may be incorrect. ${ }^{8} \mathrm{He}$ was the eldest of four siblings born into an artisan family. He was six when his father died, he was raised by his mother with the assistance of a supportive extended family, and he grew to maturity in a period of change in both Scottish and English societies. ${ }^{9}$ Macandrew lived in and about Aberdeen, a city shaped by Highlands traditions and was a young man during the period of fierce religious debate which led to the Disruption of 1843 and the partition of the Church of Scotland. He advanced his career in the booming business world of London of the 1840s, married into a well-established merchant family and migrated to New Zealand in his own ship in 1850, seemingly, a successful, Victorian entrepreneur.

Macandrew's baptism on 18 May 1819 is recorded in the Baptismal Records of the Old Machar Parish Church, Aberdeen, although an entry in the Macandrew family bible in

\footnotetext{
${ }^{4}$ Edmund Bohan, Edward Stafford: New Zealand's First Statesman, Christchurch, Hazard Press, 1994, p. 9: 'Those men who sat in parliament between 1854 and the 1870s included some of the best educated, most accomplished, widely travelled, colourful and interesting personalities who have ever involved themselves in this country's public life.'

${ }^{5}$ Denis Le Cren, The Rich and Macandrew Families 1280-1993, Nelson, Denis Le Cren, 1993, pp. 82-85.

${ }^{6}$ Letter: Marsha Donaldson/Tom Brooking, 11 June 1984.

7 James Macandrew married Eliza Reynolds on 17 October 1848. General Register Office Marriage Certificate, Copy MX 936224, issued in East London 19 November 1985.

${ }^{8}$ McLintock, Otago, p. 323 quotes J.G.S. Grant that Macandrew was born in Fortrose.

${ }^{9}$ Le Cren, p. 82.
} 
his handwriting gives his birthday as 17 May $1820 .{ }^{10}$ If the original birth date is correct and he was christened the following day, why did he enter the incorrect year in his bible, repeat the error in the United Kingdom Census of 1841 where his age is listed as 21 and perpetuate it on his wedding certificate in 1848 where his age is entered as $28 ?^{11}$ The spelling of his surname had changed and his father's status had improved by the time of Macandrew's marriage. Such minor details may have been genuine mistakes or an attempt to improve his social status, but they may also indicate Macandrew's casual attitude to accuracy, which, in financial dealings, led him into serious strife.

Other children followed James: Daniel, born in 1821; Jane, born in 1823; and Lewis, born in 1825. That Daniel was a witness at Macandrew's wedding and accompanied him on the Titan to Dunedin in 1850, with Macandrew's parents-in-law, Macandrew's brother-in-law and the three children of another brother-in-law, suggests that Macandrew's commitment to his extended families was strong. ${ }^{12}$ Daniel remained in Dunedin for three years before returning to Aberdeen and the pair co-operated in a number of business ventures. ${ }^{13}$ Jane may have stayed with Macandrew in London before marrying Alex Gillespie, later a London merchant, while nothing is known of Lewis' life. ${ }^{14}$ The Uncle John Macandrew who sponsored the family gravestone at Fortrose contributed to James' upbringing, both financially and emotionally, and provided the support his nephew might have received from Colin if he had lived longer.

The family's home at the time of Macandrew's baptism was Summer Street in Aberdeen. In 1819 Aberdeen was a small city surrounded by country villages including Woodside, the site of one of the two Summer Streets in the city. ${ }^{15}$ Woodside then stood beside the railway line running northwest from the city centre, south of the River Don, and

\footnotetext{
${ }^{10}$ Baptismal Register, Old Machar Parish Church, Aberdeen, 18 May 1819, 18/05/1819 MCANDREW, JAMES [O.P.R. Births 168/B00 00500610 OLD MACHAR]. http://www.scotlandspeople.gov.uk/: 'Colin McAndrew Shoemaker, Summer Street and his Spouse Barbara Johnston had a son born named James, baptised by the Rev Professor Kidd. Witnesses were James and Samuel Johnston.' The Macandrew Family Bible, Otago Settlers' Museum, Dunedin, lists (in Macandrew's handwriting) 1820 as his birth year.

${ }^{11}$ London 1841 Census,_Obbba32d01db8027d3a224b2464d608e.pdf, http://www.ukcensusonline.com/search/index.php?fn=james\&sn=macandrew\&phonetic mode $=1 \&$ event $=18$ $\frac{41}{12}$

${ }^{\frac{41}{12}}$ Eliza's brother William Reynolds was the other witness at their wedding and became James' business partner in New Zealand.

${ }^{13}$ Daniel Macandrew, 1821-91. Architect, emigrated N.Z. 1850, resident Dunedin 1850-54, practised Aberdeen 1855-91.

${ }^{14}$ Waddy, Charles, The Wanderings and Doings of a British Family in England, Scotland, Portugal, Spain and New Zealand, unpublished manuscript history of the Reynolds Family, Seddon, New Zealand, 2011, p. 43.

${ }^{15}$ Encyclopaedia Britannica, 9th Edition (1875) and 10th Edition (1902), Population of Aberdeen in 1801, 26,992; in 1841, 63,262. http://www.1902encyclopedia.com/A/ABE/aberdeen.html
} 
was separated by fields from urban Aberdeen. The Cathedral of St Machar - also known as the Old Machar Parish Church - is in Old Aberdeen, approximately two kilometres across open country to the east of the Summer Street in Woodside. ${ }^{16}$ A village upbringing would have given Macandrew a healthier start to life than life in a city dwelling.

Le Cren claims that Colin Macandrew lived all his life in Aberdeen but Waddy claims that the family lived at Fortrose, near Inverness, where James attended Fortrose Academy. ${ }^{17}$ After Colin's death in 1825 , the family shifted to Drumoak on Deeside, nineteen kilometres inland from Aberdeen, ${ }^{18}$ where Macandrew attended a parish school until he was at least thirteen years old but there is no evidence of his having advanced to secondary schooling. ${ }^{19}$ The Encyclopedia of New Zealand states that he attended Ayr Academy which is unlikely, given that Ayr is south west of Aberdeen on the opposite coast of Scotland. ${ }^{20}$ Macandrew's personal skills were enhanced at his church and it was later noted that 'he was greatly indebted for his political education to Young Men's Debating Clubs in connection with Trinity Church, Aberdeen, under the Rev. David Simpson, and London Wall Presbyterian Church, under Dr. Tweedie. ${ }^{21}$

In 1836 Macandrew was apprenticed to Pirie and Co., Paper Merchants of Aberdeen when a letter from an Edinburgh-based cousin indicated the preoccupations of their poor but genteel class. His cousin James wrote 'I am happy to learn you are in a good situation. Yours is a delightful business for making a fortune fast, altho' in some instances by speculation too largely you may founder \& go at once from affluence to poverty' and, presciently, given Macandrew's later career - 'In short even already I find the accountant profession a very good one...I advise you however to endeavour to keep out of our clutches in the Bankrupt way I mean. ${ }^{22}$ With few surviving letters after these, it is difficult to know what part the extended Macandrew family remaining in Britain played in his life after he migrated to New Zealand.

\footnotetext{
${ }^{16}$ John Wilson The Gazetteer of Scotland, published 1882, $3^{\text {rd }}$ printing, 2002, p. 3 http://books.google.co.nz/.

${ }^{17}$ Le Cren, p. 81; Waddy, p. 41.

${ }^{18}$ Daily Free Press, Obituary, Daniel Macandrew, born Fortrose 1821.

${ }^{19}$ HL MS-0619 is an Exercise Book inscribed 'James Macandrews book 18 Sept $^{\mathrm{r}} 1832$ ' on the inside front cover and 'James Macandrews Book $11^{\text {th }} \operatorname{Jan}^{\mathrm{y}} 1833^{\text {' }}$ on the inside back cover. It contains 44 pages filled with Arithmetic Exercises written in a regular and mature copperplate script. The exercises include topics such as Compound Interest, Discount and Profit and Loss.

${ }^{20}$ Hall, 'MACANDREW, James'. http://www.TeAra.govt.nz/1966/M/MacandrewJames/en; Letter: David Walton, Asst Registrar, Ayr Academy/Tom Brooking, 30 April 1985. The school could not confirm that Macandrew attended it.

${ }^{21}$ Aberdeen Weekly Journal, 22 August 1891.

${ }^{22}$ Letter: James McLean Macandrew/James Macandrew (no date) January 1836, HL MS-00-111/2.
} 
Two years later, when Macandrew was about to transfer to London, still in Pirie and Co.'s employment, his uncle John encouraged him with advice at some length and invoked the values that typified struggling families with little capital who had to make their own way in the world:

I am glad to observe that you are sensible that in the great City of London, you will be exposed to new temptations, and that you need the protection of the Father of the fatherless... My dear James, if you are spared, \& preserved in the paths of virtue (which may God grant of his great goodness) I think you are in a fair way of gradually (and that is the only safe way) working up into perhaps a situation of importance \& emolument, and becoming yourself through time a British merchant of some eminence...Do all in your power, in a lawful way, to promote the interest of your employers, at their back, equally as when their eyes are on you-and depend upon it that in the long run, you, as well as they in the meantime, will reap the reward...I'll pay $£ 2$ to the British Linen Bank here tomorrow, in your name, \& which you will get from their agent at Aberdeen on Saturday. ${ }^{23}$

In his letter, John invoked the blessing of God four times, reminded the eighteen year-old James to avoid the temptations of London, and to be virtuous, law abiding, love his family and be respectful of his employers. Hard work would eventually bring rewards. Raised in a religious family, Macandrew had a strong Christian faith throughout his lifetime and God's protection is always invoked in the few extant letters written by him to his children. When he died, an obituarist observed that 'all Mr Macandrew's speeches abound in Biblical quotations, thus proving that he was a constant student of the good old book. With the exception of a stray quotation from his national poet, Burns, nearly all the others are from the Bible. ${ }^{, 24}$ Even his everyday language was laced with Old Testament references.

London was Macandrew's home from 1838 until 1850, where he developed his business skills, accumulated and lost capital, enjoyed a middle class lifestyle, married and began a family. The London Macandrew arrived in was undergoing an immense transformation. Its booming economy enabled breakneck redevelopment: slums were being replaced by endless brick terraces, major railway stations were opening which made the city more accessible to the rest of the country and centrepieces such as Trafalgar Square and the Houses of Parliament were under development. As well, Irish Famine and the Scottish Diaspora drew large numbers of refugees to the capital from 1845 onwards. An overloaded sewerage system led to cholera pandemics that killed at least 6,000 people

\footnotetext{
${ }^{23}$ Letter: John Macandrew/James Macandrew, 22 March 1838, KWMSS.

${ }^{24}$ Clutha Leader, 4 March 1887.
} 
in $1832,14,000$ in $1849,10,000$ more in 1854 and further deaths throughout the century until effective sanitation and better housing eradicated the disease. ${ }^{25}$ However, a rapidly growing population with all its material demands led to ample business opportunities.

Macandrew's stay with Pirie and Co. was short and successful and a Dunedin contemporary later described his career with the firm: 'He entered the office of a large establishment, whose ramifications extended to the limits of commerce, and from the desk of a junior clerk he rapidly rose to the highest post in the concern-that of chief correspondent. This latter he also gave up and started as a merchant on his own account. ${ }^{26}$ The large establishment was owned by paper merchant Robert Ragg who introduced him to the congregation of the Scotch Church at London Wall, before Macandrew left him to launch Garden \& Macandrew.

Robert Garden was in business on his own account in 1842, and a series of letters between him and Messrs Oliver \& Boyd, Booksellers of Edinburgh, show that a Scottish business connection existed before Garden and Macandrew was established in $1845 .{ }^{27}$ Robert Garden acted as an agent for the booksellers, sold advertising for them, distributed their books in London and pursued debtors for the Scottish company. These business activities continued when Macandrew joined Garden—locating lost consignments, dealing with the Excise and soliciting advertising for Oliver \& Boyd. Income from the Oliver \& Boyd account was small — a statement of accounts for the last quarter of 1847 showed a commission of $£ 4.8 .0$ charged on advertising placed worth $£ 107.4 .8 .^{28}$

In 1847 Garden \& Macandrew, now iron merchants, occupied premises at 27 Queen Street, Cheapside. Ill health and business failure haunted the self-employed, and if middle-class men like Macandrew aspired to a certain lifestyle, then using family

${ }^{25}$ J.N. Hay, Epidemics and pandemics: their impacts on human history, Santa Barbara, Cal: ABC-CLIO Ltd, 2005, p. 230, viewed at http://books.google.co.nz/books?id=GyE8Qt$\mathrm{kS} 1 \mathrm{kC} \&$ printsec $=$ frontcover\&source $=\mathrm{gbs}$ atb $\# \mathrm{v}=$ onepage $\& \mathrm{q} \& \mathrm{f}=$ false

${ }^{26}$ James Adam, Twenty Five Years of Emigrant Life in the South of New Zealand, Edinburgh, Bell and Bradfute, 1876, p. 63. Adam is quoting Macandrew so his words should be treated cautiously.

${ }^{27}$ Waddy, p. 42, states Garden's father was a Scottish merchant who had migrated to Canada and Robert was born in 1818 in Montreal; London 1841 Census 0bbba32d01db8027d3a224b2464d608e.pdf, Folio Reference, HO107/1052/4/ F39. The UK Census of 1841 shows Robert Garden, Clerk, aged 22 and James Macandrew, Clerk, aged 21 living with Isaac and Eliza Pitman at St Georges Terrace, Wells St (now Wells Way), Camberwell; National Library of Scotland MSS, Acc 5000/Vols. 201, 203, 204, 205, 206, 207, Business letters: Oliver \& Boyd, Booksellers of Edinburgh/Robert Garden, then Garden \& Macandrew of London 1841-1850.

${ }^{28}$ Letter: Garden \& Macandrew/Oliver \& Boyd, 10 February 1847. NLS MSS, Acc 5000/Vol. 204. Approximately $\$ 384.00$ and $\$ 7780.00$ in 2012.

http://www.moneysorter.co.uk/calculator_inflation2.html\#calculator. 
connections in the pursuit of business was acceptable. A letter from his cousin Donald Macandrew, an Edinburgh commission agent, discussed the sort of employment considered appropriate to men of their class—-sales and commission work. ${ }^{29}$ Donald could not help Macandrew to establish an agency for 'Scotch Pig Iron' but added that 'I am therefore happy that you have abandoned the offered post abroad, and I hope that you will give up the idea entirely now and plod away at home.' While the more ambitious Macandrew appears to have considered and rejected migration as a route to advancement, it is unclear where and what the 'offered post abroad' had been. When he did migrate three years later, no doubt spurred by the economic depression and the cholera epidemics of the late 1840s, and possibly by business failure, it was on his own terms, on his own ship. But the rising businessman had sufficient time and money for holidays and marriage. Donald asked 'Have you any thoughts of coming North this season? What would you think of spending a few days in Edin \& then on to Aberdeen \& Fortrose?' and mentions Macandrew's impending marriage, which suggests he had accumulated sufficient resources to support a wife.

It is unknown if Macandrew capitalised on any other Scottish connections for his business activities but Donald referred to Macandrew's selling 'Welch Iron' and in the Miners Almanack of 1849, under the heading of 'Coal And Iron Companies' is the 'Yniscedwyn Anthracite Iron Company (Garden \& Macandrew). 27 Queen-street' while listed under 'Iron And Steel Merchants' is 'Garden \& Macandrew. 27, Queen-street, City. ${ }^{30}$ The same listings appear, with another entry in the Advertisements section, in the 1851 Miners Almanack which was published after James had sailed for New Zealand in September 1850. The firm supplied a specialised range of engineering materials and the continued advertising suggests that the partnership continued although the company may have been in financial difficulty.

\footnotetext{
${ }^{29}$ Letter: Donald Macandrew/James Macandrew, 9 September 1847, KWMSS.

${ }^{30}$ Henry English, ed., The Mining Almanack for 1849, London, The Mining Journal Office, pp. 529 \& 531, and The Mining Manual and Almanack for 1851, pp. 427, 428, 429. See also the Advertisements Section at the end of the book.
} 


\section{STIRLING'S PATENT YELLOW METALS}

Adapted for SHEATHING, BOLT STAVES, BOLT NAILS, DECK NAILS, as reported on by the late Mr Owens, Supervisor of metals to the Admiralty: also for PROPELLORS, FRAMEWORK SCREWS, PISTONS, CYLINDERS, COCKS (particularly where there is exposure to corrosion), RAILWAY CARRIAGE AXLE BEARINGS, and for all machinery subject to friction.

AGENTS

Messrs GARDEN \& MACANDREW, 34, Dowgate-hill, London Messrs JOHNSON, 166, Buchanan-street, Glasgow

Applications for licences and other information to be addressed to the undersigned, at Garden \& Macandrew's, 34, Dowgate-hill.

ALFRED BARRETT, Manager

Railway companies were important customers for Garden \& Macandrew and Macandrew gained knowledge of the mining and maritime worlds as their business expanded. The company's enterprises covered a wide range of activities and their agency for yellow metals (bronze castings) indicates they were dealing in the expensive end of the market, with, no doubt, a higher rate of profit. By 1851, the partnership was operating from two different offices, Queen-street and Dowgate-hill, just two blocks apart in The City.

Other sources of Macandrew's income are unclear. The Yniscedwyn Anthracite Iron Company may have been established in partnership with either a George Crane who died in 1846, or his son Patrick who continued to run the iron foundry at Yniscedwyn, in the Tawy Valley, twenty kilometres from Swansea, using anthracite coal from the Hendraladus Colliery. George Crane patented the smelting of iron ore using anthracite coal and presumably Garden \& Macandrew acted as agents for his products. ${ }^{31}$ When Macandrew arrived in New Zealand in 1851, he placed an advertisement seeking business for another company, Messrs Macandrew, Crane and Co. of London. ${ }^{32}$ However, it may have been a different Patrick Crane who managed Macandrew's affairs in London after his departure for Otago - whoever he was, Mr Crane was trusted by Macandrew and his colleagues to expedite the flow of settlers to Otago.

Macandrew was unceasingly active and committed to self-improvement: in 1882 he reminisced that 'when I was a young man I spent about a dozen years of my life in London, during which period I was a frequent visitor to the strangers' gallery [of the House of Commons], and if my memory is correct, I think I may safely say that I have

\footnotetext{
${ }^{31}$ Solomon Roberts, Obituary of George Crane, Journal of the Franklin Institute, Vol. 41, Issue 3, March 1846, p. 214.

${ }^{32}$ OW, 22 March 1851.
} 
listened to debates in the General Assembly of New Zealand quite as able as any I heard at Westminster. ${ }^{, 33}$ His knowledge of parliamentary procedure would stand him in good stead in New Zealand. As well as familiarising himself with the parliamentary system, he also spent time in London with the officials at the Colonial Office, who managed the affairs of the Empire.

The Scotch Church at London Wall was a meeting place for evangelical Presbyterian expatriates and Macandrew joined the congregation in $1838 .{ }^{34}$ After the Disruption of the Church of Scotland in 1843 and the establishment of the breakaway Free Church of Scotland, it became an active centre for émigré Free Church adherents, and eventually cut its formal ties with other Scottish denominations. ${ }^{35}$ In this congregation, Macandrew would have been introduced to promoters of the Otago settlement in New Zealand and it was where he first met the Reynolds family-Thomas and Marion, their son William, born in Kent in 1822 and their daughter Eliza, born in Oporto in 1827—when they joined the Church in $1841 .^{36}$ Thomas Reynolds senior was born in 1783, and had been a lieutenant in the Royal Navy before becoming the proprietor of cork plantations in Spain. ${ }^{37}$ The family departed Portugal for Edinburgh on the outbreak of revolution in 1828 and returned to Lisbon in 1834. That the business was prosperous is confirmed in William's obituary which states that he returned to London in 1842 to run the family firm where 'as much as $£ 180,000$ a year passed through his hands.' 38 Macandrew was obviously acceptable to the Reynolds family because he and Eliza were married on 17 October 1848. ${ }^{39}$ Already, Macandrew and William Reynolds shared an interest in

\footnotetext{
${ }^{33}$ Wanganui Herald, 25 October 1882.

${ }^{34}$ Guildhall Communion Records, London.

${ }^{35}$ George G. Cameron, The Scots Kirk in London. Oxford, Becket Publications, 1979, p. 26.

${ }^{36}$ Phillida Macdonald, Eliza's Journal. Christchurch, P Macdonald, 2000, p. 4. The older sons Thomas and Robert were living in Portugal at this time.

${ }^{37}$ OW, 6 April 1899. Obituary: William Hunter Reynolds. This obituary is incorrect: the plantations were in Portugal and William grew up in Oporto.

Thomas Reynolds, 1783-1867.

Marion Hunter, 1786-1869, m. Thomas Reynolds 1809.

Thomas William Reynolds, 1811-98.

Robert Hunter Reynolds, 1820-72.

William Hunter Reynolds, 1822-99, migrated N.Z. 1851, merchant, m. Rachel Pinkerton 1856, Member OPC 1853-76, Executive Otago Council 1854-60, 1862-63, 1865, MHR 1863-78, Minister of Customs (Waterhouse Ministry) 1872-73, Minister of Customs (Fox Ministry) 1873, Colonial Secretary and Minister of Customs (Vogel Ministry) 1873-75, Minister of Customs (Pollen Ministry) 1875-76, Member Executive Council (Stout Ministry) 1884-85, 1886-87, MLC 1878-99. Eliza Hunter Reynolds, 1827-75, m. James Macandrew 1848. ${ }^{38} \mathrm{OW}, 6$ April 1899. $£ 180,000$ is approximately $£ 16,940,000$ in 2012.

${ }^{39}$ Eliza was aged 21 and Macandrew was aged 29. Perhaps he changed his age to lessen the age gap.
} 
migration and later persuaded members of both families to accompany them to New Zealand.

Macandrew's close bond with the entrepreneurial, travelled, wealthy and socially well-established Reynolds family no doubt boosted his confidence, further shaped his values and bolstered his finances for the rest of his life. There is no evidence of the originator of the plan to migrate to New Zealand although in 1847 Macandrew had considered and rejected employment abroad. The cohesive Reynolds clan shared a common world-view and saw prosperous opportunities in another country-by September 1850 most of them departed in their ship Titan for their new life in New Zealand.

\section{The Free Church of Scotland Settlement at Otago}

New Zealand became a significant migrant destination when the New Zealand Company's ship Tory departed Plymouth on 12 May 1839, carrying a land-purchasing expedition, followed by nine migrant ships whose passengers established the settlements of Wellington, Nelson, Wanganui and New Plymouth. ${ }^{40}$ The Company was founded on a proposal for the 'systematic' settlement of New Zealand advanced by Edward Gibbon Wakefield who attracted a coterie of Establishment backers. Following the signing of the Treaty of Waitangi, the Company received a charter for land sales and was granted sole rights to sponsor any further settlements. ${ }^{41}$ In July 1842 a Scotsman, George Rennie approached the Directors of the New Zealand Company with his scheme to 'save the institutions of England from being swept away in an uncontrollable rebellion of the stomach' by assisting 'the unemployed and destitute masses' to migrate. He contended, somewhat undiplomatically, that earlier settlements in New Zealand had been poorly planned and he proposed that an advance party establish the necessary infrastructure for a new settlement before a main body of settlers departed. ${ }^{42}$ The New Zealand Company's plans for further migration to New Zealand were at this time meeting resistance from an unsympathetic Tory government and Colonial Office due to confusion over land titles and Maori hostility to their settlements so the Directors rebuffed Rennie's approach.

\footnotetext{
${ }^{40}$ Philip Temple, A Sort of Conscience: The Wakefields, Auckland, Auckland University Press, 2003, pp. $223-239$.

${ }^{41}$ Edward Gibbon Wakefield, 1796-1862. employed British Diplomatic Service, imprisoned for abduction, adviser to Lord Durham on Canadian government, designed colonising model for South Australia where income from artificially high land prices subsidised the passage of labourers, Director New Zealand Co., 1839, Member Canadian House of Assembly 1842-44, emigrated New Zealand 1853, Member Wellington PC 1853-55, MHR for Hutt 1853-55.

${ }^{42}$ Colonial Gazette, 17 August 1842; New Zealand Journal, 20 August 1842.
} 
In May 1843, Rennie, now associated with Captain William Cargill, returned to the Company with a revised proposal for a Scottish Class Settlement. ${ }^{43}$ In it, he claimed that

the great bulk of the Colonists, as well capitalist as laborers, who have emigrated in connection with the New Zealand Company have proceeded from England; and that Scotland has taken but small part in an enterprise for which her people are eminently qualified by their self-reliance, industry, perseverance, and prudence. We are desirous, therefore, that the proposed Colony should be made particularly eligible for Scottish immigrants of all the various classes which constitute society;... we propose that the plan of the Colony shall comprise a provision for religious and educational purposes, in connection with the Presbyterian Church of Scotland; and that the whole of the emigration fund arising from the sale of the Company's lands in the settlement, shall be employed in promoting the emigration of persons of the labouring class of Scotland only.

The Company, this time, approved their proposal and Rennie and Cargill arranged for Reverend Doctor Candlish and Robert Cargill (Captain Cargill's brother) to present the proposal to the Acting Committee of the Colonial Scheme of the Free Church of Scotland in June 1843. This body warmly endorsed it, thinking that it referred to the Free Church, rather than the continuing Church of Scotland, although which branch of the Presbyterian Church of Scotland Rennie meant has been debated vigorously since then. ${ }^{44}$ The Committee adopted the proposal, promised to find a Minister and a Schoolmaster for the expedition and at the second meeting of the Free Church of Scotland Assembly in October 1843 announced that the Reverend Thomas Burns would be the first minister of the projected colony. ${ }^{45}$

Thomas Burns was 47 years old, had held the prestigious Church of Scotland living at Monckton in Ayrshire for the previous thirteen years but had left the Established Church at the Disruption and was without a parish. He was known throughout the country as a pious and highly principled man who was capable of seeing a difficult task such as colonising a new country through to its conclusion. His determination that the new colony

\footnotetext{
${ }^{43}$ New Zealand Journal, 8 July 1843, p. 178.

William Cargill, 1784-1860 had a Nonconformist upbringing, was a veteran of the Napoleonic Wars, and had banking experience before he sailed, aged 64, with five of his seventeen children, as chief administrator of the Otago Settlement. First Superintendent of Otago Province and a Member of the General Assembly, he counterbalanced Macandrew's more extreme proposals in the Otago Provincial Council of the 1850s.

${ }^{44}$ T.M. Hocken, Contributions to the Early History of New Zealand (Settlement of Otago), London, Sampson, Low, Marston and Co., 1898, p. 20; McLintock, Otago, p. 174; E.N. Merrington, A Great Coloniser: Rev Dr Thomas Burns, Dunedin, Otago Daily Times and Witness Newspapers, 1929, p. 78.

${ }^{45}$ McLintock, Otago, p. 174.
} 
would be a strictly Free Church Settlement led to a closer relationship with William Cargill and a complete split with Rennie. ${ }^{46}$

But the Free Church refused to sponsor the scheme. It was prepared to give its blessing as it had in June 1843, but would not adopt it as an official Church undertaking. One reason for the Church's lack of support was given by the Rev. Dr. Candlish who did not 'like our Church courts to be saying much about emigration in any shape just now: it looks so like playing into the hands of Lairds and factors, taking up their cuckoo song, and seeking to do what they so cruelly want to do; viz. drive away the people to make their lands a desert. ${ }^{, 47}$ Crop failures, famine, cholera outbreaks and the Clearances were taking their toll on the Scottish population and another emigration scheme, while well-meaning, could have had negative implications for the country.

In 1845 an independent Lay Association of Scotland for promoting the settlement of 'the colony of Otago' was formed in Glasgow because 'the Free Church supporters of the Otago scheme would more readily place their confidence in a purely Scottish concern mainly because the New Zealand Company, by reason of its protracted negotiations with the Government, was fast losing the confidence of investors. ${ }^{48}$ Burns also wanted to disassociate the Scheme from the New Zealand Company because he considered that 'Gibbon Wakefield's name in Scotland would bring no favour, no confidence with it. ${ }^{, 49}$ However, as the New Zealand Company was the only body with a Charter from the British Government to organise migration to New Zealand, the Otago Lay Association remained under the company's aegis and never acquired its own charter and independence.

Land for George Rennie's original New Edinburgh Settlement had been chosen in 1844 when Frederick Tuckett, principal surveyor of the New Zealand Company's Nelson Settlement, was commissioned by the Company's Wellington-based Principal Agent Colonel William Wakefield to select a site in the Middle Island for a proposed Scottish Settlement. After exploring and rejecting possible sites in what were to become Canterbury, North Otago and Southland, Tuckett signed a memorandum on 31 July 1844 with twentyfive of the leading Otago chiefs, including the leaders Tuhawaiki, Taiaroa and Karetai, for

${ }^{46}$ Bunce, Roderick, 'The Trust Funds for Religious and Educational Uses at Otago 1842 to 1866', MA thesis, University of Otago, 1982.

Rev. Thomas Burns, 1796-1871, nephew of Robert Burns, Minister Church of Scotland then Minister Free Church from 1843, Minister to the colony of Otago 1847, Foundation Chancellor of University of Otago 1869.

${ }^{47}$ Letter: Rev. Dr. Candlish/Cargill, 9 September 1847, HL, MSS-0075.

${ }^{48}$ McLintock, Otago, p. 201.

${ }^{49}$ Letter: Thomas Burns/Cargill, 2 May 1845, HL, MSS-0076, quoted in McLintock, Otago, p. 201. 
a 'block of country from Otago Harbour to the Molyneux, with the exception of certain areas to be set aside as native reserves, for the sum of two thousand four hundred pounds. ${ }^{, 50}$ This was the Otago Block of 400,000 acres [160,000 hectares]. In September 1845, the Otago Lay Association, headed now by the Reverend Thomas Burns and Captain William Cargill, who had also accepted the appointment of New Zealand Company's Resident Agent at Otago, finalised its arrangements with the New Zealand Company and agreed to establish the Otago Settlement on a smaller block of 144,600 acres $[57,274$ hectares].

The eventual Otago Block was to be divided into 2,400 properties of $601 / 4$ acres, each consisting of three packages, a town, a suburban and a rural allotment. Of these, 2000 properties were to be sold to settlers, 100 were to be bought by the Local Municipal Government, 100 were to be bought by the Trustees of the Fund for Religious and Educational Uses and 200 were to be bought by the New Zealand Company. At $£ 2$ an acre, sales would generate $£ 289,200$ of which three-eighths would be spent on Emigration and supply of labour, two-eighths on Civil uses, i.e. providing infrastructure for the settlement, one-eighth for Religious and educational uses and two-eighths would be paid to the New Zealand Company as a return on its investment. ${ }^{51}$

\section{London Preparations}

If the Free Church of Scotland had not established the Otago Settlement, Macandrew probably would not have gone to New Zealand. Records suggest that by 1850 he was in financial strife so emigration may have been the easiest way for him to elude his creditors. ${ }^{52}$ His wife's family were not intimidated by the prospect of establishing themselves in a new land and were sufficiently prosperous to underwrite the expedition but it is most likely that the clinching attraction for him was the Scottish, Presbyterian ethos of Otago.

Macandrew's interest in migration and his Free Church membership saw him appointed to the London Committee of the Otago Lay Association in 1845 and William Reynolds also formed a connection with the Association, but the years between 1845 and 1847 were discouraging ones when little action transpired. ${ }^{53}$ As a man who keenly sought to control events, Macandrew threw himself into the organisation of the Otago expedition

\footnotetext{
${ }^{50}$ McLintock, Otago, p. 142.

${ }^{51}$ Ibid., p. 208.

${ }^{52}$ Daily News, London, 29 October 1851; Glasgow Herald, 10 November 1851.

${ }^{53}$ ST, 26 February 1887, 'Obituary, James Macandrew'; OW, 6 April 1899, 'Obituary, W.H. Reynolds'.
} 
and came to wield a certain amount of power. On the Committee, Macandrew mixed with the enthusiasts and advocates, the politicians and civil servants who were determining the fate of New Zealand. As they met in New Zealand House, the New Zealand Company's offices in London's Broad Street, Macandrew would have met Edward Gibbon Wakefield, one of its Directors, and his clansmen, and been exposed to Wakefield's colonising theories, while Committee work introduced him to the modus operandi of both Whig and Tory Secretaries of State for War and the Colonies.

In June 1846 Lord John Russell's pro-emigration, pro-colonizing Whigs were elected and with the backing of Colonial Secretary Earl Grey, the New Zealand Government Act was passed in December. This spurred the issue of a fourth version of the Terms of Purchase by the New Zealand Company in June $1847,{ }^{54}$ the dormant Otago Lay Association stirred into action, ${ }^{55}$ and the first Otago-bound ships sailed before the end of 1847. John Wickliffe departed on 24 November with ninety-seven emigrants led by William Cargill while Philip Laing left three days later with Thomas Burns in charge of a further two hundred and forty-seven settlers. ${ }^{56}$

The departure of the first ships, which were followed by three more in 1848, eight in 1849 and five in 1850 did not noticeably enthuse the members of the Otago Lay Association. ${ }^{57}$ They were told that as far as publicity was concerned, 'a considerable portion of this distribution has not yet had time to fructify,' that with land sales 'the undertaking has had to contend against the pernicious effects of detraction,' that 'the infrequency of intelligence has operated unfavourably' while 'of all obstacles, what Dr. Chalmers used to call "the unimpressibility of the masses" is the greatest., 58

In London, despite the gloomy outlook, Macandrew played an increasingly active part in the foundation of Otago. Poor land sales in Otago meant development costs were not being met, and by May 1850, the Association owed the New Zealand Company

${ }^{54}$ Terms of Purchase of Land in the Settlement of Otago, June 1847. HL, MSS-Pam 124/2.

${ }^{55}$ Letter: Secretary of Otago Lay Association John McGlashan/Secretary of the New Zealand Company T.C. Harington 15 May 1849, HL, MSS-0077, describes the impressive marketing activities undertaken by the Association which revitalised the Otago project: 12,000 copies of an Address, 10,000 copies of the Otago Journal, 800 copies of a Circular, 8,000 copies of a Handbill were distributed in Scotland, 1000 newspaper advertisements were run.

John McGlashan, 1802-64. Scottish solicitor, full time Secretary of the Otago Association in Edinburgh from 1846-52, leading campaigner for the settlement of Otago. Worked closely with Macandrew in Britain and in Otago, especially in the Provincial Council. Macandrew turned on him in 1857 and accused him of dishonesty when Macandrew was caught misusing official funds.

${ }^{56}$ McLintock, Otago, p. 235.

${ }^{57}$ Hocken, Contributions, pp 286-296.

${ }^{58}$ A Report of the Edinburgh Committee of the Otago Association to the Special General Meeting of the Association, 25 May 1850, HL, MSS-0077. 
$£ 30,000$. No further advances would be forthcoming. ${ }^{59}$ As a member of the Otago Lay Association's London Committee and a confidant of the Association's Edinburgh-based Secretary, John McGlashan, Macandrew would have known of the looming crisis. Yet he chose to commit his future to Otago in June 1850 when he applied for land there, only a few weeks before the financial collapse of the New Zealand Company. Macandrew's opportunism can be identified here as he used the occasion to criticize McGlashan for the failings of the Association while boosting his own contribution. Perhaps Macandrew perceived that with the incubus of the New Zealand Company shed, the Otago Lay Association was freed to deal directly with the British Government, which might bring self-government to the colony a step closer.

Some of Macandrew's lifelong values and habits were revealed in his letter of 14 June 1850 to John McGlashan: his attitude to money and his eye for a bargain. He wrote

I enclose a cheque for L120-10/ being the purchase money for one property in Otago...I intend to apply for two other properties but as the parties for whom I am to purchase them do not sail until September, I do not wish to have the money lying idle until then, and I would not have paid for one now, but for the sake of obtaining a passage for a man and his wife whom I intend to send out by the July vessel...I observe from the papers sent up lately for the consideration of the London Committee that the New Zealand Company seem to underrate the exertion of the Association in making sales, and therefor it is that I intend to trouble you with my payment, so that you may at least have the credit of them. ${ }^{60}$

This was powerful leverage: Macandrew made the minimum outlay for the maximum return, in this case, a sponsored passage for others, credit for unpaid for sections and a percentage for the Association, as well as an early choice of desirable land.

Macandrew's self-assurance and his Scottish origins were obvious in this letter. He told McGlashan how to do his job, commenting 'I feel perfectly assured of this that had proper steps been taken to make the London Committee something more than a mere name, if it had got a habitation and an active paid Secretary, the Settlement of Otago might have been ere now nearly all bought up there is an immence field here...I am inclined to think that the Association and its functions are made very light of and that to use a scotch phrase they [the New Zealand Company] are now calling out stinkin fish.' But while happy to give unsolicited advice for improving the Association's situation, when asked to do

\footnotetext{
${ }^{59}$ Letter: Harington /McGlashan, 3 May 1850, HL, MSS-0077.

${ }^{60}$ Letter: Macandrew/McGlashan, 14 June 1850, HL, MSS-0078.
} 
something concrete, he cried off. ${ }^{61} \mathrm{He}$ added that 'I am convinced that if the Association were to act with spirit they might be in the same position as the Canterbury Association, and have the formation of the colony entirely in their own hands as it is now the influence of the Otago Association, upon the character of the Colony (excepting in as far as the emigrants are concerned) is a perfect farce.' One of his strengths was adopting the ideas of others-his Canterbury reference indicates his familiarity with events in the Southern Hemisphere.

He concluded his letter with talk of a superior ship and the establishment of a branch of his London 'house' and exhibited his habitual politicking with his reference to confidentiality about a bank he proposed to found in Otago. 'I mention it to you in confidence - if however you should find the knowledge of the fact, likely to be useful in operating upon parties about to proceed to the Settlement, you are at liberty to make use of the information.' Perhaps he wanted little publicity because he had not yet secured financial backing. Nor was he committed to permanent emigration and at this stage of his planning, he noted that 'I may state to you that our house here has lately been extending its business and operations in our Southern colonies, and that with the view of further extension and consolidation, it is probable that I shall go out for some years myself, making Otago my headquarters.' However, New Zealand became his permanent home and he never returned to Great Britain. Macandrew's predisposition to take control of events, his drive to shape the Otago settlement and his tendency to endow plans with grand and fanciful outcomes is evident through the events of this time.

McGlashan was quick to use Macandrew's information to boost Otago which was experiencing teething pains: the surveying and allocation of sections was slow and a small group of the settlers were creating discord. In a progress report to William Cargill, now the leader of the Otago Lay Association settlers in Dunedin and also the New Zealand Company Agent for Otago, he summarised the problems the Association was facing at both ends of the earth: 'Our progress in Landsales continues to be depressingly slow; but what else could be expected, in the whole circumstances - the New Zealand Company denounced by Mr Wakefield - its members clamouring for its dissolution-its terms of existence approaching, when die it must unless it receive an addition to its days- the

\footnotetext{
${ }^{61}$ Letter: Macandrew/McGlashan, 17 July 1850, HL, MSS-0078: 'As regards your suggestion of having the head office of the Association here - it would require a great deal of consideration-I am not sure that such a step would be advisable although I think the vessels should be dispatched from here as there will be little chance of their procuring cargo in Scotland.'
} 
hostility of the Otago News, which is doing more harm than I could have supposed from Settlers injudiciously supporting it, and sending home, I would almost say maliciously sending home, copies of it - complaints from the Settlers of want of energy and, apparently, means, among many of the Land owners - complaints of the roads, which are represented to be wet weather canals of liquid mud... ${ }^{62} \mathrm{He}$ then passed on the exaggerated news of Macandrew. 'But yet we are not without some progress. Besides the New Zealand Company's own ships, there are no less than three private adventure ships about to proceed....The one direct is a ship of Messr Garden and MacAndrew; which is to carry out only First Class passengers, who are Capitalists and are to make Otago their home.' McGlashan's thankless task as a Home Agent required a large degree of optimism and tact when transmitting news.

Four days later, McGlashan advised Thomas Harington, Secretary of the New Zealand Company, of 'A Bank about to be formed in Dunedin by a party of capitalists principally Free Churchmen - and such an amount of Capital the Association has been assured by one of the projectors, is to be employed in the business as will place the bank on a solid foundation. ${ }^{63}$ In his next despatch to Otago, McGlashan buoyed expectations even further: 'A number of Capitalists are about to settle in Otago. Amongst them is $\mathrm{Mr}$ Jas Macandrew who with others propose to establish a Bank with a capital amply sufficient. Their party leaves in a ship of their own in August next. They are staunchly Free Church. ${ }^{64}$ Every item of good news had to be harvested many times for this project.

Macandrew's next proposals were floated on 28 June 1850 when he put the case to McGlashan for a paid Secretary for the London Committee of the Otago Lay Association and he proposed that the Minister of his London Church accompany him to Otago. He wrote: 'The grand point which I am anxious to secure is a standing thero [sic], either ministerially, or as the founder of a superior educational institute which might ultimately emerge into a Free Church College' a first reference to a university in Otago, and another of Macandrew's flights of fancy. ${ }^{65}$ No secretary was appointed and although the Rev. Nicholson did accompany the family to New Zealand, it was neither as an academic nor to minister in Otago.

\footnotetext{
${ }^{62}$ Letter: McGlashan/Cargill, 14 June 1850, HL, MSS-0077.

${ }^{63}$ Letter: McGlashan/Harington, 19 June 1950, HL, MSS-0077.

${ }^{64}$ Letter: McGlashan/Cargill, 28 June 1850, HL, MSS-0077.

${ }^{65}$ Letter: Macandrew/McGlashan, 28 June 1850, HL, MSS-0078. The College was to train Free Church Ministers for the colony. McGlashan offered employment at it when trying to recruit an editor for the Lay Association's newspaper.
} 
The demise of the New Zealand Company on 5 July 1850 left the Otago Lay Association exposed. ${ }^{66}$ Again, Macandrew saw opportunity in adversity and wrote: 'Now is the time for the Association to step in and occupy the same position as the Canterbury people...I would strongly impress upon you the necessity of making the attempt at least to get the whole affair into our hands'. Nor did Otago have to be purely Scottish if Scots would not migrate and others would: 'No doubt Scotland is the place to look to for the kind of labour which we want, but London is the grand source from whence Capital and Capitalists may be most readily drawn. ${ }^{67}$ His brother-in-law, no doubt encouraged by Macandrew, also wrote to McGlashan and reiterated that the lack of support from England to date 'is no indication however that if proper means were adopted it would not secure the sympathies and support of English people, (and Dissenters from the Church of England especially) to which it is fairly entitled. ${ }^{68}$ Macandrew's suggestion of wider recruitment was accepted although the presence of a band of Englishmen was to have an unhappy outcome and eventually undermine the Free Church control of the settlement.

Macandrew pressured McGlashan to step up his lobbying for a charter. ${ }^{69}$ Reynolds reported on 15 July 1850 that Macandrew had requested Otago's long time backer Rev William Chalmers to ask his parishioners, Fox Maule M.P. and the Marquis of Breadalbane, to act as go-betweens and arrange a meeting with higher Colonial Office officials. ${ }^{70}$ Working together, the brothers-in-law were a prevailing force, prepared to recruit from all classes of society for the Settlement's cause. Macandrew reported a successful lobbying visit on 17 July and issued further instructions: 'I need not enlarge upon the subject further than to express the hope that you will lose no time in drawing up the draft of a Charter. From the disposition of the Colonial Office I have every reason to think that the Association may fix its own terms - and the Authorities there seem to be quite alive to the necessity of dispatch. ${ }^{, 71}$ McGlashan followed Macandrew's directions with a more sober letter to the Colonial Secretary, applying subtle pressure by informing him that 'several capitalists' were about to depart for Otago, to establish a Bank amongst other things, and the 'capital intended to be employed will not be less than from sixty to seventy thousand pounds. ${ }^{72}$ As well, other parties wanted to buy land and if they could not

\footnotetext{
${ }^{66}$ McLintock, Otago, p. 313.

${ }^{67}$ Letter: Macandrew/McGlashan, 11 July 1850, HL, MSS-0078.

${ }^{68}$ Letter: W.H. Reynolds/McGlashan, 12 July 1850, HL, MSS-0078.

${ }^{69}$ Letter: Macandrew/McGlashan, 12 July 1850, HL, MSS-0078.

${ }^{70}$ Letter: W. H. Reynolds/McGlashan, 15 July 1850, HL, MSS-0078.

${ }^{71}$ Letter: Macandrew/McGlashan, 17 July 1850, HL, MSS-0078.

${ }^{72}$ Letter: McGlashan/Earl Grey, 8 August 1850, HL, MSS-0078.
} 
go soon, they would not go at all. McGlashan asked for $£ 400$ a year to run an office in London, and softened the original exclusive Terms of Purchase, writing 'The Association do not exclude from the benefits of the Scheme Episcopalians and others, who are satisfied with the Institutions in Otago, and who are themselves of good character-all that they ask is proof of character and friendliness to the institutions' and reported that a number of families from other denominations had signed up to emigrate.

As a result of the Association's lobbying of the Colonial Secretary Earl Grey, it appeared that the Association might become a legal body with its own Charter, giving it an independent commercial footing. ${ }^{73}$ On 4 September 1850 , Macandrew joined a delegation, with John McGlashan and other members of the Association to meet with Colonial UnderSecretary Herman Merivale to discuss ways for the Association to continue its operations. ${ }^{74}$ No progress was made. ${ }^{75}$ Earl Grey now baulked at their requests and placed the Association under the temporary aegis of the Colonial Land and Emigration Commission, a branch of the Colonial Office-definitely not an outcome desired by the Association members. ${ }^{76}$ In early 1851 he ruled that the revised Terms of Purchase signed in June 1849 would remain in force, no Charter would be granted to the Association, the proportion of the land sale monies that previously went to the New Zealand Company from the Otago Lay Association would now go to the Crown because it had taken over the Company's liabilities and the Association would be granted a 5\% commission on land sales for its own use. If the Association was determined to have a Charter, the Crown would take no responsibility for the Association's liabilities.

The clamour for a Charter ceased but Macandrew, as was to happen many times in his lifetime, emerged smelling of roses. An obituary, forty years after the event, stated that in the 'tedious and difficult negotiations with the New Zealand Company and the Colonial Office, it is said, and is easily credible, that Mr Macandrew's great industry and tact, and doubtless his irrepressible hopefulness had much to do with the success of the scheme. ${ }^{77}$

\footnotetext{
${ }^{73}$ OW, 8 February 1851.

${ }^{74}$ Letter: McGlashan/James Watson, Chairman of the London Committee of the Otago Lay Association, 14 September 1850, HL, MSS-0078: 'In your absence I was aided by Mr James Macandrew now on his way to Otago, his partner Mr Crane, [my emphasis] Mr Robert Roxburgh Mr Anderson and Mr W Cargill a son of Captain Cargill.'

${ }^{75}$ Letter: Benjamin Hawes, Under-Secretary of State/Cargill, 29 August 1850, HL, MSS-0080. This is different from one sent to Macandrew on 2 September 1850 which had raised the expectations of the Otago Lay Association Committee..

${ }^{76}$ Letter: Benjamin Hawes/Macandrew, 2 September 1850, HL, MSS-0081.

77 ST, 26 February 1887.
} 
Given the outcome, it is unclear that Macandrew or anyone on the deputation had achieved anything, but the story improved over time probably through his own telling.

\section{EMigration to Otago}

Macandrew was one of Belich's 'early boosters,' a man who had committed himself to a new land and who then encouraged maximum investment by others to raise the value of his own property. ${ }^{78}$ His unquenchable optimism, based at this time on speculation rather than knowledge, was displayed in a circular letter which he distributed under the name of Garden \& Macandrew in July 1850. Just how widely Macandrew circulated this letter is unknown but two copies have been found during research for this thesis. ${ }^{79}$ This letter may be one of the most sanguine views of the future of New Zealand ever penned, exceeding even E. G. Wakefield's paeans, and in it Macandrew demonstrated his ability to think on a very wide scale. With its casual use of information, it is a wonderful example of extreme boosterism.

The letter's recipients were notified that Garden \& Macandrew had established a trading branch in New Zealand - not that it was their intention. He predicted that New Zealand's future was assured because 'there can be no doubt that from its locality, climate \& capability, it is fitted and destined to become the Great Britain of the south.' He praised its grasslands and its excellent harbours, and suggested that New Zealand's wealth would come from 'its flocks, agricultural products, Fisheries and Minerals.' A depot there for British goods would be able to serve 'most of the markets to the South of the Cape of Good Hope and Cape Horn, as well as from those situated between the Eastern Coast of Africa and Western Coast of America.' At least half the world was to be his oyster although the factual basis for his claims in unclear. He continued 'The voyage at present from Sydney \& New Zealand to Panama may be estimated at six weeks. When steamers are established it will probably take not more than half that time' which would enable goods to be ordered from New Zealand and delivered to San Francisco in three months, half the delivery time from Great Britain — not that any steamer had yet made the run. He ended with the promise 'We are sending out a very fast vessel, our purpose having one or two more such, to be entirely engaged in the intercolonial trade' and solicited support 'by

\footnotetext{
${ }^{78}$ Belich, Replenishing the Earth, p. 184.

${ }^{79}$ Circular letter: Mr James Macandrew/unnamed recipients, 27 July 1850, KWMSS. A copy dated 15 August 1850, which includes a business card naming companies in both London and New Zealand, is held by the National Library of Scotland, MSS, Acc 5000/Vol. 207 'Business letters Oliver \& Boyd, Booksellers of Edinburgh/Garden \& Macandrew'.
} 
way of sample.' His unashamed and clever boosting of opportunities for business in Otago was to pay handsomely for him.

The circular demonstrated Macandrew's enthusiasm for new technologies and his ability to identify trends before other people and then to promote them ardently. The sidewheel paddle steamers Sirius and Great Western were the first purpose-built steamships to undertake regularly scheduled trans-Atlantic crossings, from 1838, and he would have seen steamers departing from London for increasingly longer voyages around the world. ${ }^{80}$ He would also have been aware that the New Zealand Company had issued tender documents in 1849 for steamship services around the New Zealand coast and across the Tasman. ${ }^{81}$ So also would he have seen railways swiftly improve in reliability and safety in the previous decade and he could have risked talking them up. At this time, the Panama Route involved crossing the Isthmus by train and there is no evidence that he foresaw the building of a canal. He would have had nothing to lose if the future he predicted had failed to eventuate, because he would have been on the other side of the world and unable to be held to his failed prophecies.

His ability to think in sweeping terms was shown by his portrayal of half the world, from Africa to America, as a market which could be serviced from New Zealand. He appears to have been very well informed about conditions on the other side of the world: his knowledge of New Zealand's temperate climate made it safe for him to make optimistic predictions about agricultural productivity and he was aware of the booming economy in Australia, of the rapid growth of Victoria and especially of Melbourne. For migrants who expected to take three months to reach New Zealand, Victoria would look like a promising and not-too-distant market for New Zealand produce. ${ }^{82}$

Macandrew's first venture into ship owning arose when the extended Reynolds family agreed to migrate to Otago. Rather than paying for passage on a migrant ship, it was cheaper to charter his own vessel to convey his large group of relatives, as well as paying passengers and a cargo of trade goods, The Titan, a 350 ton schooner was registered by Garden and Macandrew on 3 August 1850 and chartered to Macandrew and

\footnotetext{
${ }^{80}$ John M. McKenzie, ed., The Victorian Vision: Inventing New Britain, London, V. \& A. Publications, 2004, p. 154.

${ }^{81}$ New Zealand Company TENDER TO PROVIDE STEAM COMMUNICATION IN NEW ZEALAND, 10 November 1849, HL, MSS-0079.

${ }^{82}$ Belich, Replenishing the Earth, p. 311: 'Victoria, then the Port Phillip District, had shared the later half of Australia's first boom of 1828-42, and busted with it. But a second boom began around $1847 \ldots$ the population more than doubled in the five years between 1846 and 1851, from 32,000 to 77,000.' This was before their gold rush.
} 
Co., formed by Macandrew and William Reynolds ${ }^{83}$ Charles Waddy has suggested that Robert Garden retained a Power of Attorney to enable him to reclaim his share of the investment by selling the ship when it reached New Zealand. ${ }^{84}$

What response Macandrew received to his circular is unknown but on 12 June 1850 an advertisement appeared in The Aberdeen Journal, short on details but long on persuasion. It did not name the ship and stated that it had been chartered

New Zealand-Emigration to Otago

Several Gentlemen (Capitalists) about to proceed to the above Colony, having chartered a First Class vessel, are fitting her up for a limited number of Cabin Passengers only.

To parties of respectability desirous of proceeding to the Settlement, such an opportunity rarely occurs.

The ship is built upon the most approved sailing principles for speed; and as the owner and family are going in her, every attention will be paid to comfort.

The berths being all first class, makes the passage-money considerably less than that charged by the regular traders.

As the Vessel will not sail from London until the end of August, her cabins are not yet fitted up, so that parties and families applying now may have their State-rooms arranged for one or more sleeping berths, as may be required.

For further particulars application to be made to

\section{Messrs Garden \& Macandrew \\ 34, Dowgate Hill, London}

Details were revealed in a subsequent advertisement in The Times on 25 July 1850 - ship's name, ship's size, departure date, departure point, captain's name and another agent. ${ }^{85}$ A further advertisement in The Aberdeen Journal on 31 July 1850 targeted the Scottish market again, and brought back the departure date to ' $20^{\text {th }}$ August next' and provided the projected duration of the voyage- 90 days. ${ }^{86}$

Macandrew would have been aware of the contents of McGlashan's letter of 14 June 1850 to Cargill and would have known of the problems he would meet in Otago - the underperformance of the New Zealand Company, the absence of investment in infrastructure, the rift between the Free Church adherents and those who were notlabelled the Little Enemy - which indicated the intensity of the division. He knew that the editor of the only newspaper, the Otago News, was so antagonistic to the leadership of the

\footnotetext{
${ }^{83}$ ODT, 30 January 2001, Ian Farquhar, 'Letter to editor.'

${ }^{84}$ Waddy, p. 52.

${ }^{85}$ The Times, 25 July 1850.

${ }^{86}$ The Aberdeen Journal, 31 July 1850.
} 
Settlement that when his critical copy returned to the United Kingdom it undermined the marketing of the new settlement. Macandrew was equipped to meet these challenges and sailed carrying 'a large amount in specie for the establishment of a Bank and Type \&c for a newspaper. The Gentlemen I have named are to undertake the newspaper entirely at their own risk; and will be supported in it by the Trustees for Religious and Educational Uses in the Settlement. ${ }^{87}$

The newspaper advertisements for Titan did not attract any extra passengers and the ship may have sailed with unfilled berths-Macandrew's family, staff and friends appear to have made up the ship's passengers - but the advertisements served to publicise the Otago settlement. Departure, finally, was on 7 September 1850 and the Titan arrived in Port Chalmers on 17 January $1851 .^{88}$ Apart from one death at sea, nothing untoward was reported during the voyage although Captain Cargill observed, "Your letter by the "Titan" did not reach till the $16^{\text {th }}$ inst having been 132 days on the way. No fault it is stated in the sailing qualities of the vessel, but still the longest voyage that had been made,' almost half as long again as the optimistic estimate of 90 days, made, in all likelihood, by Macandrew. ${ }^{89}$ Thomas Hocken recorded the nineteen passengers and an unknown number of crewmen commanded by George Craig who had departed Gravesend on Titan, and were welcomed in Dunedin as a 'galaxy of Free Church talent.' 90 They were

- James (aged 31, merchant) and Eliza (24) Macandrew and their son Colin (1);

- Daniel Macandrew, brother to James (27, architect);

- Thomas (67, cork merchant) and Marion (65) Reynolds, James' parents-in-law;

- their son William (26, merchant);

- Thomas (13), Maria (11) and Robert (10) Reynolds, grandchildren of Thomas and Marion, the children of Thomas Reynolds Jnr. who had remarried and remained in Portugal;

- Rev. William Nicolson (55), Macandrew's Minister from the Scots Church, London Wall and his son Ralph (23, pharmacist);

- Job Wain (14) who was employed to mind Colin;

- Beatrice Fowler (25, servant);

- James Saunders (24, bank clerk);

- George Shaw (artist and engraver),

- J. Smith (carpenter);

- James Scott (22, carpenter) who 'was a native of Aberdeen, and was born and spent his early years in the same street as the Macandrew family."

- W Blyth died en route and was buried at sea.

${ }^{87}$ Letter: McGlashan/I. Langmuir, 10 September 1850, HL, MSS-0078.

${ }^{88}$ Hocken, Contributions, p. 323, records Titan's voyage dates as 5 September 1850 to 15 January 1851.

Three different arrival dates are recorded by various writers.

${ }^{89}$ Letter: Cargill/McGlashan, 21 June 1851, HL, MSS-0081.

${ }^{90}$ Hocken, Contributions, p. 323; New Zealander, 15 February 1851.

${ }^{91}$ Bruce Herald, 12 August 1887. 'Obituary, James Scott.' 
James Macandrew had arrived in his Great Britain of the south where he was welcomed as a successful and wealthy Scottish businessman, his reputation enhanced by his London experience and his entrance in his own ship. His connection with the Otago Lay Association had demonstrated that he was an effective committeeman and a forceful administrator who had helped to animate a torpid organisation. He had the organising skills to move his extended family and his worldly goods to the Antipodes, he had a long experience of practical matters as well as a comprehensive knowledge of matters ranging from the technical to the political, including theories of government. He was an energetic, self-confident optimist whose Presbyterian values did not hamper his hard-nosed commercial endeavours. He was self-assured and socially adept, at ease with the many Oxbridge educated Englishmen who were filling the higher level government positions, as well as with his artisan and labouring fellow immigrants. His faults of over-confidence and impetuosity, his casual approach to record keeping, the haphazard management of his affairs, and at times, his disregard for truth, would emerge later to injure his reputation and subvert his achievements.

He was an extremely plausible and persuasive man who could astonish New Zealand audiences with his grand visions and convince his listeners that his goals were achievable. He was to warrant Brooking's description of him as one of the three great optimists of the nineteenth century Pakeha world, alongside Edward Gibbon Wakefield and Julius Vogel. ${ }^{92}$ The next decade was to see him become wealthy beyond his dreams, then bankrupted, subjected to the indignities of poverty and rejected by his community. His behaviour polarised his fellow citizens and he was a lightning rod for media commentators. Throughout his life he attracted fierce criticism and high praise.

\footnotetext{
${ }^{92}$ Speech: Tom Brooking to Rich and Macandrew Families descendants, 15 February 2001, Dunedin.
} 


\section{ChaPTER 3}

\section{SETTLER: DUNEDIN 1851-1861}

In the decade from his arrival in Dunedin on 17 January 1851 to his imprisonment on 28 January 1861 Macandrew emerged as a prominent citizen, wealthy businessman and an influential politician. During this time, he was a party to many of the significant events in Otago and in the wider New Zealand setting as his business activities, especially his shipping services, grew within and beyond the country. His name quickly became prominent, while his political activities ensured him an even higher public profile. As a founder member of New Zealand's Parliament and a member of its second Ministry, if only for three days in August 1854, he worked and socialised with leading citizens and was acquainted with the leaders of the other Provinces. Crowning his accomplishments, on 3 January 1860, he was elected to the position of Superintendent of Otago Province, the highest political position in the Province. His celebrity then transformed to notoriety when he was declared bankrupt and imprisoned in Dunedin gaol for six months.

Chapters three and four will examine Macandrew's life as he established himself in Otago. Chapter three will explore his life as a citizen in Dunedin where he rapidly became a pillar of the community, a leading member of the Free Church and founded his business empire. Chapter four will focus on his public life as a politician as he served on local, provincial and colonial bodies. Inevitably, activities in both spheres overlapped and it is doubtful if Macandrew made any effort to keep them separate-he is known to have engineered political outcomes to further his business interests. His business life was interwoven with his life in the community so that almost every event in which he was involved — social, political and business—eventually supported his financial activities.

Macandrew's personal life in the 1850s falls into two convenient periods, when he was making his fortune and when he was losing it and these will be the basis of chapter three. In the civic arena he was elected or appointed to virtually every public body that emerged in that decade, while in the business sphere, there seemed to be no area in which he was not involved - as a merchant, trader, insurance-broker, landowner, estate-agent, farmer, banker, newspaper proprietor, manufacturer, shipping and immigrant agent. As European settlement accelerated and as exploitation of the country's natural resources intensified, risk-taking investors such as he made huge returns. 
How typical then, was Macandrew? In the 1850s and 60s enough businessmen made large fortunes in New Zealand to suggest that Macandrew's business success was not unique. ${ }^{1}$ Men such as John Logan Campbell of Auckland, Nathaniel Levin and Barney Rhodes of Wellington, Edward Reece of Canterbury, John Jones and Donald Reid of Otago had similar experiences: they arrived before or during the establishment of the settlements, they had limited capital to invest and they earned their money in a wide variety of ways. ${ }^{2}$ Macandrew exploited the booming 1850s but over-reached and lost his capital before withdrawing completely from commercial pursuits. Where other entrepreneurs weathered the peaks and troughs of the New Zealand economy and retained their fortunes, Macandrew chose to opt out. He is unusual in that he had choices, he could have returned to the business world and the Reynolds family would surely have supported him. At a time when honourable bankruptcy was acceptable, the status of Macandrew's bankruptcy was debated, and for the next decade his behaviour was considered by many to be barely acceptable. He would have been taken back into business circles even though he had come perilously close to criminal behaviour but his interest in commerce disappeared after his imprisonment. Instead, he committed himself to full time politics, an unusual career move for those times.

\footnotetext{
${ }^{1}$ Olive Trotter, Pioneers Behind Bars: Dunedin Prison and its Earliest Inmates, 1850-1870, Dunedin, Olive Trotter, 2002, p. 36: 'He had a prosperous business as a general merchant and importer, and was also a stock agent. All this brought him a profit it was said of $£ 20,000$ a year. He had invested in land all over Otago-at Portobello and Waikari and South Otago, even as far off as Invercargill.' This would be more than $\$ 2$ million now.

${ }^{2}$ John Logan Campbell, 1817-1912. Brown \& Campbell was a merchant firm established in Auckland in 1840. Colonist, 27 June 1913 reports Campbell's estate was valued at $£ 227,966(2012 \approx \$ 34,551,000)$. All calculations are made on The Reserve Bank of New Zealand website

http://www.rbnz.govt.nz/statistics/0135595.html).

Nathaniel Levin, 1818-1903. merchant and trader. Roberta Nicholls. 'Levin, Nathaniel William-Biography', from the Dictionary of New Zealand Biography. Te Ara-the Encyclopedia of New Zealand, updated 2-Aug11. http://www.TeAra.govt.nz/en/biographies/117/1. "At the time of his death, even though much of his colonial property had been passed on to Willie and his family, Levin still had assets in New Zealand worth $£ 104,818$.' (2012 $\$ 17,257,164)$.

William Barnard Rhodes, 1807-78. Brad Patterson. 'Rhodes, William Barnard-Biography', from the Dictionary of New Zealand Biography. Te Ara-the Encyclopedia of New Zealand, updated 1-Sep-10. http://www.TeAra.govt.nz/en/biographies/1r7/1, 'by 1853 he was already being referred to as 'the millionaire of Wellington.' At his death he was described as 'one of the richest men in the country'.'

Edward Reece, 1834-85. Ironmonger, Christchurch. Jim McAloon, No Idle Rich: the Wealthy in Canterbury \& Otago 1840-1914, Dunedin, University of Otago Press, 2002, p. 57. Reece's estate was valued at $£ 81,798$ $(2012 \approx \$ 14,481,045)$.

John Jones, 1809-69. McAloon, No Idle Rich, p. 33. Jones’ estate was valued at $£ 60,000(2012 \approx \$ 6,718,614)$. Donald Reid, 1833-1919. McAloon, No Idle Rich, p. 57. Reid's estate was valued at $£ 170,000$ $(2012 \approx \$ 16,239,638)$.
} 


\section{MAKING HIS FORTUNE}

John McGlashan articulated his view of an ideal society when he described Dunedin: 'the Settlement as you are perhaps aware, is peculiarly a Scotch one-it is composed of no single class or sect but forms an epitome of Home Society in the lower, and through different grades to the apex of the Middle Classes. The greatest care having been taken in the selection of the laboring class, it is of the elite of the Scottish Peasantry; and altogether, according to the testimony of disinterested and impartial witnesses its Community is highly moral intelligent and enterprising. ${ }^{3}$ The reality was different. A fresh beginning in a new land gave settlers an opportunity to start with a clean state in establishing a new society - the new arrivals challenged the utility of many practices in the home country and established their own modus vivendi. In Otago, it appeared that people were bickering over every minor decision, arguing over administrative, financial, educational and infrastructure matters, with settler pitted against settler but in fact, it was a period of challenging and testing the old verities. Macandrew thrived in these conditions, where opportunity was often unimpeded by convention or law.

\section{Public Roles}

When Macandrew arrived the settlement was only three years old and had a population of 1455, which was over four times the 344 original settlers who had departed Britain in 1847, rapid growth for a distant and isolated outpost. ${ }^{4}$ Scots were still in the majority but the intended Free Church ethos had been diluted. ${ }^{5}$ While dissension appeared commonplace, on closer study people who seemingly were sworn enemies on one issue were found co-operating closely on another. ${ }^{6}$ Macandrew, blessed by fortuitous timing, unbounded optimism and a gregariousness which endeared him to citizens of all classes, flourished in this emerging community where he "was accorded a place in society which doubtless coincided with his ambitions. ${ }^{7}$ Even when certain financial deceits were exposed in 1851, few of the settlers knew or cared what he had done to his fellow financiers.

On arrival, he was quickly appointed a magistrate, he became an active congregant in the First Church of Otago and he built an extravagant home, Carisbrook, for his growing

\footnotetext{
${ }^{3}$ Letter: McGlashan/John Hall Maxwell, 11 October 1851, HL, MS-0078.

${ }^{4}$ Hocken, Contributions, p. 298.

${ }^{5}$ Nelson Examiner and New Zealand Chronicle, 11 May 1850.

${ }^{6}$ Groups of Scottish and English settlers fought bitterly over many issues, but cooperated closely when establishing the Dunedin Mechanics Institute in 1851.

${ }^{7}$ McLintock, Otago, p. 324.
} 
family. He attended congregational and public meetings and festive occasions, usually took the Chair or in some way, controlled events. In this decade he seemed to be patron, appointee, or committee member — on rare occasions just an attendee — of almost every official, quasi-official or community body in Otago. Thirty years later, Macandrew reminisced that 'in the course of a busy and eventful life [he] has run everything, from a province to a newspaper. ${ }^{8}$ A perceptive local cartoonist depicted him marching forth carrying a carpet bag, captioned Macandrew, the Coming Man! $!^{9}$ By 1853 , he was easily elected to both the House of Representatives and the Otago Provincial Council. ${ }^{10}$

Within six weeks of his arrival he was appointed to committees charged with building a road from Dunedin to Port Chalmers, and to construct jetties at both ports. ${ }^{11} \mathrm{He}$ was appointed to a committee to consider changing the pasturage regulations and recommended that a Landowners' Society should be immediately founded. ${ }^{12}$ At a meeting of the Otago Horticultural Society where it was resolved to form a corresponding branch of the Highland and Agricultural Society of Scotland to be called 'The Otago Agricultural Association', he was appointed to the management council, but not to any of the working committees. ${ }^{13}$ A noticeable feature of his leadership was that he was never a foot soldier in the organisations he championed: he concentrated on strategy while leaving its execution to others.

The Otago Settlers' Association was established in May 1851 to monitor the use of money allocated by the 1847 Deed of Trust to the Emigration, Civil, Ecclesiastical and Educational Funds. ${ }^{14}$ In June Macandrew was asked to write 'home' and request that a portion of the money from land sales be spent on roading. ${ }^{15}$ That he had a role in the Otago Settlers' Association is curious as he was also a Trustee for the Fund for Religious and Educational Uses, whose money the settlers wanted for road building. Conflicting roles never seemed to bother him and it is possible he accepted the treasurer's position to keep a watching brief on events and to preserve the Funds for their original uses. It is also

\footnotetext{
${ }^{8}$ New Zealand Herald, 27 March 1884 quoted in the ODT, 3 April 1884.

${ }^{9}$ The cartoonist was James Brown. The cartoon is printed in McLintock, Otago, facing p. 360.

${ }^{10}$ Scholefield, Parliamentary Record, pp. 121 \& p. 221. Macandrew was elected to the House 27 September 1853 and to Otago Provincial Council 28 September 1853.

${ }^{11} \mathrm{OW}, 22$ March 1851, Reports of Meetings 14 March \& 5 April 1851.

${ }^{12}$ Ibid.

${ }^{13}$ Ibid., 3 May 1851.

${ }^{14}$ Minute Book No. 1, 1851, Otago Settlers' Association, Minutes of Meeting 31 May 1851, HL, MS-0032.

${ }^{15}$ Ibid., p. 12. By the time of the Association's public launch on 11 July, he was Treasurer.
} 
possible that he did want to allow a wider use of the money. ${ }^{16}$ Alternatively, he was politician enough to recognise that the Settlers' Association would become the prevailing body in the transition to self-government and he wanted to be part of it.

The Dunedin Mechanics' Institution was launched in July 1851, with Macandrew Chairman of the management committee. Advertisements announced that it was 'intended to have a Reading Room, supplied with British and Colonial papers and periodicals, to be open daily. A Library and a Museum is also in contemplation... it has been resolved to erect a suitable Building immediately' and there was $£ 130.5 .0$ in hand for the building fund, given by forty-four settlers. ${ }^{17}$ This was an ambitious plan for a struggling community only three years old but the first lecture was given by the Reverend Thomas Burns on 13 November 1851, with the official opening of the building held on 3 January $1853 .{ }^{18}$

Increasingly affluent, Macandrew was a regular donor to most worthy causes and, as a merchant, he was in the enviable position in a small community of being able to put his energy into meetings, planning and administration rather than into the hard labour of taming land, erecting shelter and growing food. He was often the first named for a good cause and usually the most generous, and it is likely that many of his donations were not widely publicised. His contributions, in cash and in kind, were spread more widely and even-handedly than many settlers might have done- to both the Presbyterian and Anglican Churches-and raise speculation about his motives. His patronage, while expected, no doubt improved his chances for appointment to formal positions in the colony and these were soon forthcoming.

That he was a desirable acquisition for this colony of Free Churchmen was marked by an announcement in the Otago Witness in March 1851: 'Appointment by His Excellency The Governor-in-Chief: James Macandrew, Esq., Otago, to be a Magistrate of the Province of New Munster. ${ }^{19}$ It is certain that he engineered this appointment as he had arranged to meet officials, including Governor Grey, during an exploratory business visit

\footnotetext{
${ }^{16}$ Letter: Burns/Macandrew, 14 April 1854, HL, MSS-0076. Fellow Trustee Thomas Burns intimated there was dissatisfaction with the Trust Deed.

${ }^{17} O W, 5$ \& 19 July 1851. Patrons Valpy, Lee, E. J. Wakefield, Jones, Turner and Chairman Macandrew were titled Esq., while 16 other office holders were either Mr. or without title. Macandrew was rarely titled Mr. in any publicity.

${ }^{18}$ Ibid., 15 November 1851, 8 January 1853.

${ }^{19}$ Ibid., 8 March 1851.
} 
northwards taken soon after his arrival in Dunedin. He had anticipated his appointment to the Bench by collecting the appropriate Book of Ordinances. ${ }^{20}$

The Magistrate's Bench had a wide range of responsibilities, backed by an arsenal of sanctions, from straightforward punishing of drunks to unusual and robust cases. One such occurred in January 1852 when Macandrew sat on a Bench of ten Justices of the Peace, with the Resident Magistrate, to hear a case of conspiracy and a case of assault. ${ }^{21}$ Physical violence was not uncommon in this frontier post and the Magistrate's Court was an essential means of peacekeeping. Even Macandrew appeared as a complainant after an aggrieved resident, another JP, had punched him at his store, and Macandrew had laid a charge of assault against his attacker. ${ }^{22}$ That an individual could occupy multiple roles in one situation-as victim, accused and judge, at the one court hearing-appeared not to bother too many citizens of this era. It was other matters that upset people and once, when a defendant was fined 40s. his brother-in-law Reynolds protested at the lightness of the penalty and announced his intention to resign as a Justice of the Peace- but he did not. ${ }^{23}$

Another role of the Magistrates' Bench was to advise Governor Grey on constitutional matters, and on 30 January 1852, they gave an opinion on the wisdom of proclaiming in the District of Otago one or several Hundreds, areas of land set aside for division into small holdings for close settlement. They also recommended that the Otago Harbour Pilot should have a boat's crew for his work-Macandrew sat on a SubCommittee of three to research its costs. The Bench also recommended that the CustomHouse be moved from Port Chalmers to Dunedin and Macandrew was appointed to the subsequent investigative Sub-Committee. Roads, bridge building and mail delivery were also discussed, with the Bench acting as a de facto Town Council, making recommendations for expenditure of the government funds allocated to Otago. ${ }^{24}$

When the Constitution Act brought self-government in 1852, another task fell to the Bench, vetting the list of settlers to be enrolled as voters, by deciding if they held title or a

\footnotetext{
${ }^{20}$ George Grey (Sir), 1812-98. Governor-in-Chief N.Z. 1846-57, Governor of N.Z. 1852-55, 1861-68, Auckland Superintendent 1875-76, MHR 1875-95, Premier 1877-79, KCB 1848, PC 1894.

Letter: Grey/Cargill, 12 February 1851, HL, MS-0080: 'I have appointed Mr. Macandrew a Justice of the Peace.'

${ }^{21}$ OW, 24 January 1852: 'The Plaintiff, His Honour Mr Justice Stephen, the Dunedin Supreme Court judge, charged the Defendants with "wilfully and wickedly conspiring, combining, confederating, and agreeing together, by handing about a document injurious to his reputation."”

${ }^{22}$ Ibid., 15 November 1851. His assailant, the Coroner, Dr. Robert Williams, was found guilty and fined 30s. and costs.

${ }^{23}$ Ibid., 25 September 1852.

${ }^{24}$ Ibid., 7 February 1852.
} 
lease to a property which would entitle them to a vote. At a sitting of the Bench in September 1852, the Justices determined whether a squatter with more than six months residency on a property qualified as a voter; whether properties were worth more than $£ 10$, the required level to gain a vote; whether one property could sustain more than one vote and whether a voter had to live on a property to secure his vote. ${ }^{25}$ Even Macandrew was caught in this process when he and business partner Thomas White claimed to be householders on the same property and were both entitled to a vote- the Court disallowed this. Macandrew then reverted from applicant to judge and continued hearing applicants at the same sitting. ${ }^{26}$ The possibility that the Magistrates would enfranchise Maori men stimulated the unhappy editor of the Otago Witness to a furious attack on the Bench where he wrote 'We, on a former occasion, stated that if the natives were to be enfranchised wholesale, that it would become a question of tobacco and blankets;... We have seen that although the Bench has been the only possessor of power in Otago for the last four years, what a miserable, puny affair it has been-stinking, as it were, in the nostrils of the public, the very members ashamed of the J. P. (Judge Pugilistic, or Judge of Pigs, as it has been called in consequence of a late addition). ${ }^{, 27}$ A thick skin was a prerequisite for a Justice although Macandrew, under pressure, could lash out at critics and was a good blamer.

Appearing regularly as a Justice of the Peace gave him power and status and Macandrew took his role as a responsible citizen seriously. His last appearance on the right side of justice may have been on 9 January 1861, just three weeks before his arrest, when he sat in judgement of Johnny Jones who appeared on 'a charge of assault and battery committed by him in his counting room. ${ }^{28}$ Perhaps it was too good an opportunity to miss the discomfort of one of his closest and enduring competitors, or perhaps, it was a welcome distraction from his own woes.

Membership of a number of official bodies followed swiftly on the heels of responsible government in 1853, either by appointment or election, and Macandrew served on the Board of Commissioners for the Management of the Public Lands in Dunedin, responsible for the Jetty and Water Frontages (the Jetty Committee) in May $1854,{ }^{29}$ the

\footnotetext{
${ }^{25}$ Ibid., 25 September 1852.

${ }^{26}$ Ibid., 2 October 1852.

${ }^{27}$ Ibid., 21 May 1853.

${ }^{28}$ Ibid., 12 January 1861.

${ }^{29}$ Ibid., appointed, 20 May 1854.
} 
Dunedin Town Board in August 1855, ${ }^{30}$ the Town District Board of Road Trustees in May $1856,{ }^{31}$ and the Waste Land Board in September $1856 .{ }^{32}$ In 1856 he suffered one of his rare electoral defeats when he polled poorly in the election for the Dunedin District Education Committee. ${ }^{33}$ Unusually, given his interest in education, he was never elected to the Otago Education Board although he was later, as Superintendent, appointed ex officio. In his lifetime, he promoted and sponsored the establishment of both Boys' and Girls' High Schools, a Normal Training School and a School of Art, the Caversham Industrial School and the University of Otago, amongst others, and it is difficult to comprehend that he had the energy and the time to undertake these voluntary activities while building a business empire and holding elected positions in two legislatures.

Macandrew was a regular church goer all his life. ${ }^{34}$ On arrival in Dunedin, he joined the First Church of Otago and within a month had taken on administrative duties as a Trustee for the Fund for Religious and Educational Uses, becoming Treasurer in $1852 .{ }^{35}$ There is no record of Macandrew serving the Church in a pastoral or spiritual role until he was appointed as an Elder on 22 December 1857 to represent the Kirk Sessions of Dunedin in the Presbytery of Otago. ${ }^{36}$ While his skills were financial and fund raising was his specialty, he was also active in ensuring that the Free Church ethos continued to drive the settlement.

John Gillies and Macandrew were named as the Deputation to the Rural Districts of the East Taieri, Waihola, Tokomairiro, and Clutha to collect the Sustentation Fund, and attend generally to the interests of the Church in their locality. ${ }^{37}$ Given the size of this district and the condition of the few existing roads, this was a sizeable and time-consuming task. When the Presbytery of Otago was inaugurated on 27 June 1854, on the arrival of the

${ }^{30}$ Ibid., elected, 25 August 1855. Macandrew resigned in anger in June 1857 over the decision of the Board and the Provincial Council to develop Maclaggan St. rather than Stafford St. as the main south road.

${ }^{31}$ Ibid., elected, 26 April 1856.

${ }^{32}$ Ibid., appointed, 27 September 1856.

${ }^{33}$ Ibid., 14 June 1856. The Education Ordinance passed on 14 March 1856 abolished the use of the Shorter Catechism as a text in public schools and reserved the funds allocated to the Trust Fund for Religious and Educational Uses to just Free Church use. As a supporter of both issues, Macandrew was probably punished by the thwarted majority of Education Committee electors.

${ }^{34}$ Erik Olssen, Encyclopedia of New Zealand, http://www.teara.govt.nz/en/biographies/1m1/1: 'To the end he remained a devoted member of the free church, walking up the steep hill to Pukehiki for divine service each Sabbath when he was at home, and resisting with all his domineering magnetism the introduction of such papist practices as hymns.'

${ }^{35}$ Minute Book of the Trustees, The Trust Fund for Religious and Educational Uses, Dunedin, 1848-67, held at the Office of the Otago Foundation Trust Board, Dunedin. Macandrew joined trustees Thomas Burns, William Cargill and Edward McGlashan on 24 March 1851, replacing Edward Lee and served until 1854, and again in $1858-59$.

${ }^{36}$ OW, 26 December 1857.

${ }^{37}$ Ibid., 5 November 1853. 
Reverends Will and Bannerman, Macandrew was appointed a member of the Sustentation Fund Committee. ${ }^{38} \mathrm{He}$ continued in this role for the rest of the decade and was a member of a committee appointed to consider the working of the General Sustentation Fund on 21 December 1859, after his election as Superintendent. ${ }^{39}$

It was as a Trustee of the Fund for Religious and Educational Uses that Macandrew made his foremost contribution to Church life. To many settlers this Fund characterised the Free Church's disproportionate control of land and funds and his connection with it made him a target for public criticism for many years. It received one-eighth of the purchase money for all land sold in the Otago Block and invested in its own estate, profits from this being used to pay for the establishment and maintenance of churches and schools. ${ }^{40}$ The Trustees were autonomous and although initially they reported annually to the Deacons' Court of First Church, then to the Presbytery of Otago from 1854, they were independent agents, beholden to no-one.

Settlers criticised the practice of allocating the income from land sales to a fund for the benefit of just one denomination, especially as land prices were kept higher than in other Settlements. Dissension grew until the Provincial Council was established when, in McLintock's words 'the period of paternalism in government, of theocratic control' finally ended. ${ }^{41}$ Macandrew's behaviour as a Trustee indicates his abiding commitment to the Free Church ethos of the settlement and his preparedness to use political influence to achieve his religious ends. Dissatisfaction with the funding of education in Otago simmered until the Provincial Council took responsibility for it and the recommendations of an Education Commission comprising Presbyterians Macandrew, Reynolds, John McGlashan and Peter Proudfoot, were implemented in an Education Ordinance passed on 14 March 1856. Unsurprisingly, this ensured that the funding for schools would be raised by charging fees and by rating all males over 21 years of age $£ 1$ a year and yet again safeguarded the Trust Fund. ${ }^{42}$ The Trustees continued to pursue the General Government

\footnotetext{
${ }^{38}$ Ibid., 8 July 1854.

${ }^{39}$ Ibid., 31 December 1859.

${ }^{40}$ Clause 6 of the Terms of Purchase allocated 100 (6025 acres) of the 2,400 Otago properties offered (144,600 acres) to the Estate of the Trust Fund for Religious and Educational Uses. The Trustees anticipated collecting $£ 36,150$ (one-eighth of the sale price of the 144,600 acres of land at 40s. an acre) and spending $£ 12,050$ to buy their 100 properties, leaving $£ 24,100$ to pay for the establishment of churches and schools. In reality, land sales were slower than expected in the six years until the establishment of the Presbytery of Otago, at which time the Estate owned 13251/2 acres and income was never enough to pay for the requisite institutions.

${ }^{41}$ McLintock, Otago, p. 348.

${ }^{42}$ Votes and Proceedings, Otago Provincial Council, Session IV, 5 and 14 March 1856, pp. 3 \& 20.
} 
for their share of the land sales money while at the same time, attempts to confiscate the Trust's assets escalated. ${ }^{43}$ Finally, the passing of the Church Lands Act in 1866 allocated part of the Trust estate to public education through the endowment of Chairs at the University of Otago, and reserved the remainder for Church use. Macandrew's later dealings with the church were from the other side, when as Superintendent he allocated funds for the removal of Bell Hill which would permit the construction of a superior First Church, and as a legislator he voted on matters concerning the church.

\section{BUSINESS ROLES}

Macandrew was certain of the place of business in the world and once proclaimed: 'Let them set up the genius of Commerce, with all its soul-expanding and elevating tendencies. Next to Christianity, it was the most powerful instrument in promoting the happiness of the human race. ${ }^{44}$ He knew how to achieve that happiness and continued that 'What he wanted was that the Otago settlers should take a leaf out of the American book-that they should borrow as much money as they possibly could invest in the productive development of the resources of the Province.' New Zealand required food, liquor, animals, ships and labour, and Macandrew supplied these in growing quantities for the rest of the decade. His income grew large by meeting a local demand for land, implements, stock and consumables, an Australian demand for foodstuffs and a British demand for wool. He had the capital to launch his trading activities and his profits soon allowed him to expand into services and communications. Macandrew's business activities were complex and far-reaching.

His initial grubstake was his package of $601 / 4$ acres, for which he paid $£ 120-10 /-$, an investment which inflated rapidly as values soared in the new settlement. ${ }^{45} \mathrm{He}$ immediately leased two sections, the south side of Manse Street between Princes and Stafford Streets from the Local Municipality, on which he built his store. In March 1853 he moved to his new home Carisbrook, a farm of two hundred and forty acres with a mansion off what is now Neidpath Road, and built a mansion. ${ }^{46}$ Trotter writes that 'on the

\footnotetext{
${ }^{43}$ Minute Book of the Trustees, 31 December 1857.

${ }^{44}$ OW, 9 October 1858 .

${ }^{45}$ Letter: Macandrew/Cargill, Commissioner of Crown Lands, Otago District, 1 October 1851, HL, MS1751-001. Macandrew owned a town allotment of a quarter of an acre ( 0.1 hectare), a suburban allotment of ten acres (four hectares) and a rural allotment of fifty acres (twenty hectares) at East Taieri.

${ }^{46}$ OW, 23 July 1853: 'Electoral Roll for the Dunedin Country District for the Year 1853-4'; ODT, 9 October 1976, Douglas Skene: 'Carisbrook was a stately home by any standards....The house, with its fine, grey slate tile roof, was a large one, indeed one of the largest in Dunedin when first erected of three levels, having
} 
Otago Peninsula he had a second farm, all the land round and including the bay that still bears the name of Macandrew. The farm was called Colinswood, and was being developed for his eldest son Colin. ${ }^{47}$

Macandrew rapidly complemented his land allotment by leasing a sizeable portfolio of sheep-grazing and farming properties and he was associated with a number of other properties, either as an owner, a lessee or a mortgagee. He and Reynolds first leased a block of 35,000 acres of land on the east side of the Taieri River in 1851 where they intended to "place $\underline{5000}$ sheep on it. ${ }^{48}$ A second block in their name was described as a 'Run in the vicinity of their Allotments. Boundaries not stated.' Finally, the pair leased a third run 'S. of the Clutha' bounded by the Clutha and Pomahaka Rivers. ${ }^{49}$ The firm also applied for three runs in the Clutha District for other settlers, presumably on commission. ${ }^{50}$ In 1860, Macandrew owned the 'leasehold and joint household' for 'Runs, Nos. 136 and 116, Hokanui, and homestead on Run No. 136. ${ }^{51}$ A further partnership, with Cuthbert Cowan 'as runholders and Stockowners' was dissolved on 31 January, $1861^{52}$ and soon after a newspaper correspondent suggested that Macandrew had made false stock returns on his Horse-shoe Bush Run [by Lake Waihola] and Hokanui Run to increase his mortgages on other properties. ${ }^{53}$ Macandrew may also have held a number of smaller blocks of land throughout the Province as Jas. Macandrew \& Co. applied in August 1858 for 200 acres at Tautuku Bush, south of Port Molyneux ${ }^{54}$ while in December 1858, five applications for rural land were made by James Macandrew, not by his firm. ${ }^{55}$

Reynolds and Macandrew formed the firm of James Macandrew \& Co. in May 1851 and operated the Dunedin store and stores at Port Molyneux ${ }^{56}$ and Invercargill, ${ }^{57}$

some 20 rooms in all-an imposing panelled hall, a sweeping staircase, a large ballroom with a sprung floor, and the largest fireplace complete with huge iron hobs to hold the logs for burning.'

${ }^{47}$ Trotter, Pioneers Behind Bars, p. 36.

${ }^{48}$ Letter: Macandrew/Cargill, Pasturage Application, 1 October 1851, HL, MSS-1571/001. Application No. 15 .

${ }^{49}$ Depasturage Licenses Applications, HL, MS-0209/006. Applications Nos. 24 and 45.

${ }^{50}$ Ibid. Application Nos. 30, 34 \& 47.

${ }^{51}$ ST, 16 July 1901. Obituary Mrs John MacGibbon senr. 'Mr MacGibbon, in partnership with Mr James Macandrew (Superintendent of Otago) had taken up the Otapiri run.' This may have been Run 136.

${ }^{5} \mathrm{OW}, 9$ February 1861.

${ }^{53}$ Ibid., 27 July 1861, 24 November 1860.

${ }^{54}$ OW, 4 September 1858.

55 Ibid., 1 January 1859.

${ }^{56} \mathrm{OW}, 24$ May 1856. A firm of Macandrew and Co. was registered in London in 1850 and there may have been more than one firm-the firm may have had a variety of names.

${ }^{57}$ ST, 25 October 1884. 
remaining partners until $1858 .^{58}$ The renamed Macandrew and Co. was sold to James Paterson \& Co. in September 1859. ${ }^{59}$ James Macandrew \& Co's first store was stocked with Titan's British goods plus some locally purchased, and advertised for business on 22 March 1851 - the store itself was opened on 17 May $1851 .^{60}$ They advertised regularly in the only newspaper-in their publicity, 'Alcohol' came between 'Gun Powder' and 'Window Glass', indicating that Macandrew had no scruples about supplying the settlers with that commodity. Alcohol was a major part of his custom even as it constituted a major concern for the community's custodians. ${ }^{61}$ The firm bought and sold sawn timber, roofing materials and Grey Sea-Stone Lime from Captain Blackie's Sections. ${ }^{62}$ Tenders for a Union Flour Mill were called by J. Macandrew \& Co in $1853 .{ }^{63}$ In 1857 and 1858 Macandrew owned what is now 24 Filleul Street which he leased to Robert Henry for use as a brickfield. ${ }^{64} \mathrm{He}$ established another brickworks in 1859 in Stafford Street, near the Town Belt ${ }^{65}$ and at its opening offered for sale 'Forty Thousand Hard-Burnt Bricks produced by Messrs Howell and Longworth'. ${ }^{66}$ Reynolds was granted an Auctioneer's licence in $1854,{ }^{67}$ and during this period, James Macandrew \& Co. extended their activities to become Land Agents ${ }^{68}$ and later, Estate Managers. ${ }^{69}$ Reynolds became a Lloyd's Agent

F.G Hall-Jones, Historical Southland, Southland Historical Committee, Invercargill, 1945, p. 125: 'In November (Nov 6) the Star arrived with...James Macandrew, with a quantity of merchandise and building materials for a store.'

${ }^{58} O W, 11$ September 1858. 'firm of JAMES MACANDREW AND COMPANY has been this day DISSOLVED by mutual consent.'

${ }^{59}$ Hocken, Contributions, p. 192.

${ }^{60} \mathrm{OW}, 22$ March 1851.

${ }^{61}$ Ibid., 12 August 1854. 'Now Landing ex "Thetis” from London ... Trueman's XX Stout, in hhds. Bass No. 3 Ale, in barrels. Whitbread and Marzetti's Bottled Ale and Stout. Geneva, Brandy, Rum, Whisky, Port and Sherry Wine, in cases. Geneva and Gin, in cases. Kent Hops...'; McLintock, Otago, p. 344: 'the duty on British and foreign spirits being as low as five shillings a gallon...customs returns for the year 1848-9 were, as Cargill admitted, little short of one thousand pounds, an appalling figure when one considers the size of the population.' The gold rush brought even thirstier citizens to Otago.

${ }^{62}$ OW, 5 \& 19 April 1851. 'The Patent Wedge Shingle... as durable as ordinary English slates, and cover the same surface at half the expense'; Ibid., 1 November 1851, 41ำ2d a bushel against Captain Blackie's 9d a bushel advertised in the $O W, 18$ October 1851.

${ }^{63}$ Ibid., 20 \& 27 August 1953.

${ }^{64}$ Section 14 in Block 17 in the Town of Dunedin, Ratesbook of the Dunedin Town Board (established 1857), Dunedin City Council Vol.4/1.

${ }^{65}$ Letter: Macandrew/Superintendent, 'Making Stafford Street passable for winter. He is starting a brick and tile works near the Town Belt', 16 March 1859, Archives New Zealand, Dunedin, AAAC 707 D500 130/c 118.

${ }^{66} \mathrm{OW}, 10$ December 1859 \& 28 April 1860.

${ }^{67}$ Reynold's licence was issued on 20 May 1854 by John McGlashan, now Provincial Treasurer of Otago.

${ }^{68} \mathrm{OW}, 16$ August 1856, 'House and Estate Agency-JAMES MACANDREW \& CO.'

${ }^{69}$ Trotter, Olive, Dunedin's Spiteful Socrates J.G.S. Grant, Dunedin, Olive Trotter, 2005, p. 22 quotes $O W$, 21 February 1852. Grant "was visited by James Macandrew as manager of Captain Cargill's estate." 
in $1851^{70}$ and in 1854 the firm became fire insurance agents for the Northern Assurance Company. ${ }^{71}$ They also leased the Otago jetty which gave their goods precedence for landing, while the collection of wharfage dues assisted their cash flow.

Maritime activities came to dominate Macandrew's career as he built, bought and chartered ships, and acted as a shipping and an immigration agent. The shipping agency provided a vital link in the import and export process, arranging stevedoring and providoring services, warehousing cargoes and marketing freight. ${ }^{72}$ The agency sold passages, loaned money to settlers to bring out friends and families, assembled return consignments, organised insurance cover, arranged repairs, recruited crew, even sold a ship if required. An advertisement in 1856 announced the despatch of five ships in one week by his firm, all of which contributed to Macandrew's reputed income of $£ 20,000$ a year. ${ }^{73}$ For the rest of his life he was involved in some way with the harbour's infrastructure, as a businessman and as the Chairman of the Provincial Council's Jetty Committee. When he was Superintendent he promoted the building of the first graving dock at Port Chalmers and oversaw its opening in March $1872 .{ }^{74}$ He served as the first Chairman of the Otago Harbour Board from 1874 to $1877 .{ }^{75}$

The firm's ship Titan was put to good use soon after their arrival when Reynolds sailed for Hobart on 20 March 1851, with some of the original cargo from London and items from New Zealand. ${ }^{76}$ He returned on 26 May with a varied cargo, loaded more goods and sailed on 3 June for the ravenous markets of the Californian goldfields. ${ }^{77}$ With the amazing luck and fortuitous timing that accompanied so many Macandrew and Reynolds family enterprises, Reynolds arrived in San Francisco soon after the fires of May and June 1851 had destroyed much of that city. An absence of storage space meant he could sell high: it was reported that 'the Otago lime, of which she took a considerable quantity as ballast, has realised about $14 \mathrm{~s}$. a bushel ${ }^{78}$ and he purchased goods 'at exceptionally low prices, in some instances at prices equal to 90 per cent below the cost at the port of

\footnotetext{
${ }^{70}$ OW, 17 May 1851: James Macandrew, \& Co. intimate 'that they have been empowered by Mr. William Hunter Reynolds, Lloyd's Agent at Otago...to act for him as such...during his temporary absence from the Colony.'

${ }^{71}$ Ibid., 26 August 1854.

${ }^{72}$ Ibid., 10 February 1855.

${ }^{73}$ Ibid., 30 August 1856.

${ }^{74}$ Gavin McLean, Otago Harbour: Currents of Controversy, Otago Harbour Board, Dunedin, 1985, p. 58.

${ }^{75}$ Ibid., p. 66.

${ }^{76} \mathrm{OW}, 5$ April 1851.

${ }^{77}$ Ibid., 21 June 1851.

${ }^{78}$ Ibid., 10 January 1852.
} 
shipment. ${ }^{79}$ Reynolds returned to Sydney with paying passengers, sold most of his cargo, loaded cattle and sheep and returned to Otago almost a year later where 'after the payment of all expenses, including the charter of the ship, this venture returned him a profit of $£ 8000$ or $£ 9000 .{ }^{80}$ In the absence of financial records, it is uncertain how much Macandrew profited from this expedition, but such large sums would have maintained the already wealthy Reynolds and their relatives in comfort.

Macandrew commissioned the building of the 40-ton sailing barge Bon Accord, launched on 22 January 1852 , followed by the Star. ${ }^{81}$ They provided services to Lake Waihola and further south. In March 1852 they announced the departure of their third craft, the Endeavour, for the Clutha. ${ }^{82}$ Larger ships arrived with 'The Splendid Fast-sailing Packet Ship Gil Blas ${ }^{83}$ which joined his fleet in 1855 to provide a Dunedin-Melbourne service. ${ }^{84}$ Meanwhile, there had been agitation for a regular and reliable New Zealand coastal steamer service which encouraged Willis and Co. to send the steamship Nelson to New Zealand in 1853. Nelson and Wellington Provinces, backed by the General Assembly, agreed to contribute to the running costs and Macandrew and Co. were appointed as her Otago Agents. Macandrew was sold on steam. ${ }^{85}$

In 1858, Macandrew, who should have been attending Parliament in Auckland, bought the laid-up Queen in Melbourne. Its arrival in Dunedin generated serious celebrations when it docked on 27 August 1858 - citizens were 'quite taken by surprise at the appearance of a steamer of such dimensions coming so far up the bay - the possibility of which would have been ridiculed but a short time ago ${ }^{86}$ while her proud owner was eulogised, unsurprisingly, in his own paper as the man who had 'conferred an inestimable benefit upon every interest in the province, political, commercial, and social.' ${ }^{87}$ Macandrew had anticipated subsidies from the governments of Victoria, Wellington and Otago but was rebuffed by Victoria and Wellington-Queen's departure from Dunedin for Melbourne on 15 September 1858 was advertised as under contract to the Provincial

\footnotetext{
79 Ibid., 6 April 1899, 'The Death of the Hon. W.H. Reynolds'.

${ }^{80}$ Ibid., 12 February $1852 \& 6$ April $1899 . £ 9000 \approx \$ 984,000$ in 2012 , which is a large return for a year's investment of time and money. Calculated on Reserve Bank of New Zealand website.

http://www.rbnz.govt.nz/statistics/0135595.html)

${ }^{81}$ Ibid., 24 January 1852.

${ }^{82}$ Ibid., 13 March 1852.

${ }^{83}$ Ibid., 20 September 1856.

${ }^{84}$ McLean, Otago Harbour, p. 17, confirms Macandrew was the owner of the sailing vessels Gil Blas, Star and Endeavour.

${ }^{85}$ New Zealand Spectator and Cook's Strait Guardian, 17 June 1854.

${ }^{86}$ Otago Colonist, 3 September 1858.

${ }^{87}$ McLintock, Otago, p. 420.
} 
Government of Otago, a subsidy which is reputed to have been won by trickery. ${ }^{88}$ A larger steamer for trans-Tasman service, the Pirate, soon followed.

The next purchase was a storage hulk, the William Hyde, bought in January 1859, and positioned at Port Chalmers as a floating warehouse, ${ }^{89}$ then in April, he invested in a 25 ton steamer, the Pride of the Yarra, renamed her New Era, and launched another Council-subsidised service, between Port Chalmers and Dunedin. ${ }^{90}$ These were his last purchases. During 1859, Macandrew's profligacy caught up with him. His assets, including his ships, ${ }^{91}$ were liquidated but the cash raised was insufficient to meet his debts, although the Lyttelton Times announced, disingenuously, that 'Mr. Macandrew, finding his political duties as Superintendent sufficient to engross his attention, has transferred all his shipping business to Mr. Greer, owner of the Oberon. ${ }^{92}$

Sheep farming was the staple industry of Otago in this decade, and wool generated the majority of the colony's income in 1857, with most being exported to Australia for onward despatch. British migrant ships returning from New Zealand scouted the coast for cargo and in another first, Macandrew and Co. chartered a ship for the transport of wool and general cargo directly to London. ${ }^{93}$ The Strathallan sailed on 25 May 1858 with 'a cargo of 800 bales of wool, containing $263,258 \mathrm{lbs}$; valued at $£ 19,010,13 \mathrm{~s}$ ' of which Macandrew and Co. sent 499 bales, Young and Co sent 184 and Johnny Jones sent 117. ${ }^{94}$ Despite this valuable export cargo, criticism was rife. The timing was wrong, her cargo was too small, and caution was invoked: 'parties should be careful not to attempt things beyond their means....A direct shipment, more especially as it was the first, should have been well done, or not done at all. ${ }^{95}$ But an account written closer to the event suggests that local rivalries undermined the trial. ${ }^{96}$ When Macandrew despatched a second chartered ship, the Strathfieldsay, to Melbourne three weeks later with 2,757 bags of oats and 59 bales of wool, the same thing happened: it was reported that 'the charterers were

${ }^{88}$ Lyttelton Times, 8 December 1858.

McLean, Otago Harbour, p. 39: 'Only by shrewdly announcing a sailing date for the Queen and then having colleagues organise a hurried but nonetheless, carefully sta; e-managed public meeting in favour of the ship, did he secure the two year contract for a monthly service to Melbourne that kept her in Otago waters.'

${ }^{89} \mathrm{OW}, 8$ January 1859.

${ }^{90}$ Ibid., 30 April 1859.

${ }^{91}$ Ibid., 25 August 1860.

${ }^{92}$ Lyttelton Times, 1 February 1860.

${ }^{93}$ McLean, Otago Harbour, p. 38. Wool comprised the bulk of that season's [1856] £22,908 worth of exports.'

${ }_{94}$ OW, 29 May 1858.

95 Ibid.

${ }^{96}$ Alex Bathgate, Picturesque Dunedin, Dunedin, Mills, Dick and Co., 1890, p. 45. 
unsupported and unfortunate, as on arrival at Melbourne prices for grain had fallen below the prices paid in Dunedin, so the cargo was stored on shipper's account. ${ }^{, 97}$ McLintock concludes that 'this unimaginative community, while it applauded Macandrew the man and responded gladly to the warmth of his leadership, and the refreshing vigour of his irrepressible personality, rejected with coldness his schemes for advancing the prosperity of the province. 98

An immigration agency was the major source of income for Macandrew's firm during the 1850s. By 1855, a severe shortage of labour in Otago and the availability of many unemployed workers in Melbourne encouraged the Provincial Council to subsidise passages to Dunedin. Reynolds was appointed an Immigration Agent and returned in September 1855 in the Gil Blas, purchased for the purpose in Melbourne, with sixty immigrants, followed soon after by a second tranche. ${ }^{99}$ It was later claimed that Reynolds had done this without charge for his services but Gil Blas was owned by Macandrew and Co. and would have turned a tidy profit for each passenger carried while back-loading cargoes of wool. ${ }^{100}$ Thereafter, the transportation of migrants expanded but grew contentious and Macandrew's name was tarnished when charges of price gouging and political intrigue emerged.

The Provincial Council was committed to increasing the number of immigrants and in 1856 allocated a further $£ 20,000$ for this purpose and appointed Immigration Agents in both London and Scotland with tenders called to transport migrants from any part of Britain. ${ }^{101}$ Macandrew and Co. won the tender at $£ 16$ per adult head, half in cash on landing and half in Provincial Government debentures, to be paid either in London or Otago in 1860,1865 and $1870 .^{102}$ The debentures were to pay $10 \%$ interest per annum which gives an insight into Macandrew's astuteness with his creation of a regular income stream for the next thirteen years. William Cutten, editor of the Otago Witness criticised the contract when he claimed that 'Mr. Godley in a letter sent to Canterbury, states that with good management emigrants can be sent out at $£ 10$ per head all round ${ }^{103}$ and claimed

\footnotetext{
${ }^{97}$ Ibid.

${ }^{98}$ McLintock, Otago, p. 422.

${ }^{99}$ McLintock, Otago, p. 365.

${ }^{100}$ ODT, 3 April 1899.

${ }^{101}$ V. and P., OPC, Session V, 9 December 1856, p. 23; OW, 20 December 1856.

${ }^{102}$ Lyttelton Times, 17 January 1857.

${ }^{103}$ OW, 24 January 1857.
} 
the contract had been 'bagged by the liberal commercial connections of the Executive.,'104 Cutten and Macandrew were obdurate enemies at this time and in the absence of other evidence these figures must be accepted cautiously but there was still a considerable profit from this venture for the partners of Macandrew and Co. ${ }^{105}$

On the heels of Cutten's critique, Superintendent Cargill attempted to change the conditions of the contract. He accused Macandrew and Co. of price gouging, and called them 'parties who would look upon the Revenues as an unknown and inexhaustible quantity, and run the province into an unwarranted amount of debt. ${ }^{106}$ A Select Committee of the Provincial Council, chaired, conveniently, by Reynolds, now his ex-partner, rebutted the charge but reported sloppy book keeping practices. ${ }^{107}$ Two years later, the contract for 2000 migrants was completed when the Gala arrived on 23 February $1860^{108}$ but later that year Macandrew, now Superintendent, was accused of misappropriating Government funds by 'making temporary use of public funds for your own private purposes' when he took a payment for passage of migrants on the Gala for his own use. ${ }^{109}$ Another Select Committee was called, Macandrew was found wanting, his business empire collapsed and by February 1861 he was in prison.

Amongst his other enterprises, Macandrew launched both a newspaper and a bank. Macandrew was a proprietor of two of the first three newspapers in Dunedin, each established to counteract the shortcomings of its predecessor, but ironically, both turned on him and paraded his real and imagined shortcomings. When Macandrew arrived with his printing press, a company of eleven shareholders was formed and the first issue of the Otago Witness was published on 8 February $1852 .{ }^{110}$ Eventually 'the printing press and types, together with the whole interests of the proprietors in the Otago Witness were

${ }^{104}$ Ibid., 25 April 1857. Macandrew was Speaker January 1856-November 1859 and Reynolds was a member of the Executive Council from 1854-1865.

${ }^{105}$ Ibid., 29 December 1860. In protesting his innocence of defalcation in a letter To the People of Otago, Macandrew said 'I can safely say, that of the $£ 40,000$ to $£ 50,000$ of public money which has been paid to me on account of steam and immigration, I never received a sixpence before it was fairly earned.' Reynolds left the firm in September 1858.

William Cutten, 1822-83. Son-in-law William Cargill, Dunedin merchant, emigration agent, editor, owner $O W$ and $O D T$, Member OPC 1853-63, 1871-73, Otago Executive Council 1854, 57, 1860-61, 1871-72, MHR 1853-55, 1878-79.

106 V. and P., OPC, Session VII, 11 November 1858, Report, Select Committee on Immigration Correspondence, Appendix, pp. 41.

${ }^{107}$ Ibid., pp. 40-1.

${ }^{108}$ Otago Colonist, 24 February 1860.

${ }^{109}$ V. and P., OPC, Session XI, 18 December 1860, Report, Select Committee on the State of the Public Accounts, Public funds, \&c., Appendix, pp. iv-xxv.

${ }^{110} \mathrm{OW}, 16$ October 1852. Ibid, 27 November 1852. 
presented to Cutten, gratuitously. ${ }^{111}$ Macandrew continued to write editorials on subjects of special significance to the settlement but when Cutten and Macandrew quarrelled in 1854, Cutten attacked Macandrew via the Otago Witness so vehemently that Macandrew was stimulated to initiate a competitor. The Otago Colonist, edited by William Lambert, was launched on 26 December 1856. Macandrew owned this paper until his financial collapse in 1860 and was as careless in its management as he was in his other business ventures. ${ }^{112}$ In a repeat of his previous humiliation, the Otago Colonist also turned on Macandrew at his imprisonment and "poured forth its scorn upon the unfortunate superintendent in language more extravagant than that employed by Cutten's paper, the Witness. ${ }^{113}$ Macandrew's contribution to the press demonstrated he was a skilful writer and confirms his determination to influence the political views of the settlement.

Reynolds and Macandrew had committed themselves to the establishment of a bank before they left Britain and they brought with them 'a large batch of notes for 10/-, $£ 1$ and $£ 5$ value' which were never used. ${ }^{114}$ Macandrew's plans for a 'Native' bank were published two months after he landed when he claimed that a bank 'would be to industry and labor what fuel is to the steam engine,- - setting all its wheels and parts in motion., ${ }^{115}$ He lauded the success of Scottish banks which were owned by local shareholders and issued their own banknotes while at the same time, he lamented the restrictions on commerce caused by the absence of a bank in Otago and criticised the New Zealand law which blocked the Scotch model by requiring a bank's shareholders to subscribe the bank's entire capital within four years. ${ }^{116}$ His Bank was stalled, despite the enthusiasm of its boosters and the support of the community; smothered, it was claimed, by Sir George Grey who 'did not decline to comply with the application for a charter, yet he allowed it to get into the circumlocution office, where, in the weary round of its many chambers, it was

${ }^{111}$ Ibid., 27 November 1852; McLintock, Otago, p. 284. All of the proprietors supervised the editor, then a subcommittee of two directed him, then the editor ran the business at arm's length.

${ }^{112}$ It became the Colonist in 1862, was incorporated into the Daily Telegraph in 1863, and closed in April 1864; OW, 27 July 1861. Macandrew said 'I lost $£ 700$ in establishing the "Colonist" newspaper. Altogether I spent $£ 1800$ or $£ 1900$ in establishing this paper, but when in 1860 I came to settle accounts with Mr. Lambert, he only paid me $£ 100$, and repudiated the remainder and denied his liability for it.'

${ }^{113}$ McLintock, Otago, p. 434.

114 Hocken, Contributions, p. 136; OW, 18 September 1875. James Macandrew 'The young Aberdonian...drew up a prospectus for the Bank of Otago, and when shares were taken up to the extent of $£ 7000$, a preliminary meeting was called, directors appointed, and, to the astonishment of the shareholders, a handful of beautifully engraved notes of the Bank of Otago were laid on the table, and the design submitted for approval.'

${ }^{115}$ OW, 19 April 1851.

${ }^{116}$ Bank Charters Act 1851, No. 13, Sect 2 (3). 
quietly but surely — as many good things are — anodyned to death. ${ }^{117}$ Hocken suggests it was to prevent competition with 'the Government paper currency of the Bank of Issue and with the monopoly enjoyed by the Union Bank' while Barr claims the result emanated from the antipathy which existed between Grey and the Scottish settlers. ${ }^{118}$

In that same year, James Macandrew \& Co. were petitioned to issue 'Promissory Notes for small amounts at short dates, it being generally understood that they would at any time be taken as Cash in payment of goods or produce at your store' which the firm, cannily, was happy to do until the establishment of the Otago Banking Company. ${ }^{119}$ Macandrew's notes circulated for over three years with one amusing outcome: Hocken reports that competing merchant Johnny Jones attempted to 'break the bank' by accumulating notes for several thousand pounds which he then asked Macandrew \& Co. to convert to cash. ${ }^{120}$ This ploy had been anticipated and his bluff was called by payment with 'bag after bag of sovereigns.' This marked the end of most of the opposition to their use and Jones then issued his own notes. The root of the antagonism to the promissory notes was finally revealed when Edward McGlashan stated that "parties in Dunedin who have taken them in payment, have been obliged to pass them off at a discount to meet their engagements...some merchants in the place refuse to take them without a discount. And do they forget that not many days ago they themselves refused to take them from Hopapoura, a Maori, on the ground they were not due?' ${ }^{121}$ Naturally, it was the businessmen who profited from the use of the Notes. ${ }^{122}$

Macandrew was typical of the many entrepreneurs who profited in this era of growth and development and earned money from a wide number of projects. He appears not to have exploited the settlers but to have encouraged the growth of trade with personal loans and extended credit. Unfortunately, he was consistently casual with other people's money and seemed unconcerned that his failed speculations meant disaster for many of his neighbours. His bankruptcy and imprisonment which are the subject of the next section, had an inevitability about them and it is remarkable that he did not crash and burn much sooner. He is distinguished by 'his early adoption of new ideas, the pushing of boundaries, the development of projects on a grand scale, the lack of concern about details which

${ }^{117}$ James Barr, The Old Identities, Dunedin, Mills, Dick \& Co., 1879, p. 100.

${ }^{118}$ Hocken, Contributions, p. 136.

${ }^{119} \mathrm{OW}, 30$ October 1852.

${ }^{120}$ Hocken, Contributions, p. 137.

${ }^{121}$ OW, 20 August 1853.

122 Ibid., 3 January 1857. The Bank Paper Currency Act 1856, No. 4 allowed the Union Bank of Australia to issue and redeem their own notes and Otago gained its first bank (a branch office only). 
would come back to haunt him, often with litigation over payments. When supported by technocrats, his projects usually succeeded but when he operated independently, they more often than not failed. ${ }^{123}$ Before his imprisonment he took large financial risks and appeared to care little for the consequences of his poor investments; afterwards, he was a more cautious man.

\section{LOSING HIS FORTUNE}

Macandrew's commercial proposals were often undermined by his propensity for risk taking and his casual use of other people's money. Early signals emerged regarding careless practice in London as well as in the first years of his residence in Dunedin where he disconcerted leading citizens with his careless use of credit. Yet he continued to charm and many were pleased to be counted as his friends, happily investing in his business schemes.

In October 1851, a year after his departure, a public notice appeared in the Daily News of London under the heading of 'Macandrew, Crane and Co., and Garden and Macandrew-The Creditors of Robert Garden and James Macandrew, being two of a firm of three persons styled Macandrew, Crane, and Co...who have not signed the Deed of Trust for the benefit of the Creditors of Robert Garden and James Macandrew are requested to sign the same ${ }^{, 124}$ with a similar one placed in the Glasgow Herald a week later. ${ }^{125}$ Nine years later, another public notice in the Daily News and in The Times asked 'the CREDITORS of ROBERT GARDEN and JAMES MACANDREW, formerly of Dowgate-hill, in the City of London, and of the Colony of New Zealand, merchants and co-partners, trading under the firm or style of Garden and Macandrew at the date of a certain indenture of assignment executed by the said firm for the benefit of their creditors on the $19^{\text {th }}$ day of June 1851, and who executed or assented to the said indenture, are, by their solicitors on or before the $2^{\mathrm{d}}$ day of November, 1860 , to come in and prove their debts at the Chambers of the Master of the Rolls, in the Rolls-yard, Chancery-lane, Middlesex. ${ }^{, 126}$ All was revealed in July 1861 when Macandrew testified in the Dunedin Supreme Court during his application for his discharge from debtors' prison, and described his cash flow problems: 'I lost altogether $£ 8300$ on account of a partnership in London, for the debts of which I have been held liable through the dissolution of partnership not being

${ }^{123}$ Ibid., 4 March 1887.

${ }^{124}$ Daily News, London, 29 October 1851.

${ }^{125}$ Glasgow Herald, 10 November 1851.

${ }^{126}$ Daily News, London, 11 and 14 August 1860; The Times, London, 15 August 1860. 
gazetted. ${ }^{, 127}$ This demonstrated a lack of sympathy for his creditors and his tendency to blame others for his misfortunes, characteristic behaviour which would emerge when his questionable business practices were exposed.

The existence of the mysterious New Zealand firm of Macandrew, Crane \& Co. has never been established. It may never have officially existed, nor is anything known about his partner, Mr. Crane, who continued to be active in London on behalf of the Otago Lay Association. But the firm caused concern and a close study of some of its activities reveals much about Victorian financial processes. No sooner was Macandrew ashore in Dunedin, than he advertised, twice

Messrs. Macandrew, Crane, and Co., of London, beg to state that they are prepared to transact every kind of business between the Settlement of Otago and the Mother-Country...

Messrs. Macandrew, Crane, \& Co., beg further to state, for the information of such parties as may be receiving Money from Home, that they are ready to grant Letters of Credit, or Bills of Exchange, AT PAR, Upon their House in the Colony, payable in gold; thereby obviating the expense which has hitherto been incurred in its transmission, either through the banks or by ships. ${ }^{128}$

William Cargill made use of this firm's services to send money Home but the response, after the usual six months turnaround, was disturbing. ${ }^{129}$ Macandrew, Crane \& Co. declined to honour Macandrew \& Co.'s draft for twenty five pounds. ${ }^{130}$ This happened again in January for larger amounts but McGlashan defended Macandrew, writing that 'the energy of the Messrs Macandrew, and their enterprise were laudable, and deepen the regret at what has so unexpectedly occurred. ${ }^{131}$ McGlashan continued to complain of inaction in February and March. ${ }^{132}$ When McGlashan wrote to Harington at the New Zealand Company in July he identified Crane as 'Patrick Moir Crane, 18 Canonbury Villas, Islington, London' and noted that 'I understand Mr. Crane has admitted to parties that he is a partner with Mr. Macandrew. ${ }^{133}$ To which McGlashan received a stinging reply and the news that the matter of non-payment had gone higher, to the Secretary of State, no less. Harington replied that the Directors

\footnotetext{
${ }^{127}$ OW, 27 July 1861.

${ }^{128}$ Ibid., 8 and 22 March 1851.

${ }^{129}$ Letter: Cargill/McGlashan, 29 July 1851, HL, MS-0080: 'I further enclosed you... $1^{\text {st }}$ of exchange James Macandrew \& Co on Macandrew Crane \& Co $£ 25$ for purchase of two town allotments in Dunedin by (Mr. Justice) Sydney Stephen to whom the Land Orders were also to be sent.'

${ }^{130}$ Letter: McGlashan/Cargill, 11 November 1851, HL, MSS-0078.

${ }^{131}$ Letter: McGlashan/Cargill, 6 January 1852, HL, MSS-0078. Crane's reply is not available.

${ }^{132}$ Letters: McGlashan/Cargill, 19 February 1852, 20 March 1852, HL, MSS-0078.

${ }^{133}$ Letter: McGlashan/Harington, 28 July 1852, HL, MSS-0078.
} 
have been somewhat at a loss to understand what can have been your motive, either in taking a private Bill... as a channel of transmission and payment to the Commissioners of Colonial Lands and Emigration...upon further enquiry, a statement is made to the effect that the Firm of "Messrs Macandrew Crane \& Co," was only a contemplated Firm, which had no actual existence. Under the circumstances, the Bill in question has been forwarded to the Secretary of State for the Colonies, specially endorsed over to the Colonial Land and Emigration Commissioners, and will in all probability be returned to the Colony burdened with Protest Charges...I am instructed to request that you will on no account consider yourself as authorized to enter into any similar transaction, or indeed, into any transaction, whatever, on behalf of the company. ${ }^{134}$

McGlashan had to tell Cargill that the debt remained unpaid. ${ }^{135}$ Macandrew's debts were settled eighteen months later in a way that demonstrated the difficulty of doing business half a world away, with no banks to transmit funds, as an account was settled only when cash was presented or a bill of exchange received from a debtors. ${ }^{136}$ With these payments, the matter was settled, without damage to Macandrew's reputation in Otago where Cargill had already endorsed him as a political candidate, claiming 'Macandrew will in either case be the mainspring of our representative element and you may fully rely upon him,' despite his tardy payment having been reported to the Colonial Office. ${ }^{137}$

Macandrew appears to have been tolerant of tardy payment by others, and relaxed about providing credit when it increased patronage of his firm, advertising 'The Undersigned are Purchasers of Grain for Exportation, and as from the state of the roads it is impossible to get produce forward during the stay of a vessel in port, they have made arrangements to store Grain in Dunedin free of charge...J Macandrew \& Co. ${ }^{138}$ and for two years he advertised 'The Undersigned beg to intimate that they will continue to purchase or make advances on all descriptions of Produce. James Macandrew \& Co., ${ }^{139} \mathrm{He}$

\footnotetext{
${ }^{134}$ Letter: Harington/McGlashan, 30 July 1852, HL, MSS-0079.

${ }^{135}$ McLintock, Otago, p. 324. McLintock claims that Macandrew and Crane 'existed solely as a figment of Macandrew's imagination...(and) was known to one man and one man alone, and he for obvious reasons, was not prepared to enlighten a credulous community of the nebulous character of his financial entanglements'; Letter: McGlashan/Cargill, 7 May 1852, HL, MSS-0078; 'I may notice here also that Mr. Crane a partner of Mr. James Macandrew attended with us upon the Canterbury Committee and Sir John Pakington.' Patrick Crane provided yeoman service on behalf of Otago in London, as a participant in the Otago Lay Association's meetings with politicians.

${ }^{136}$ Letter: McGlashan/Cargill, 21 February 1853, HL, MSS-0078: 'I am this morning in receipt of...your letters dated 25 September and $14^{\text {th }}$ October 1852, the former enclosing Bill of Exchange for $£ 115$ by Frederick Brock Holinshead upon Messrs Twining \& Co endorsed by James Macandrew \& Co and payable to me, in lieu of the unaccepted Bills for $£ 90$ and $£ 25$ formerly transmitted.'

${ }^{137}$ Letter: McGlashan/Cargill, 12 April 1853, HL, MSS-0078; Letter: Cargill/McGlashan, 20 November 1852, HL, MS-463/028.

${ }^{138}$ OW, 7 May 1853.

${ }^{139}$ Ibid., 15 April 1854 to 30 August 1856.
} 
appreciated the need for financial services and although defeated in his attempt to establish a Bank, he used promissory notes effectively to encourage trade. ${ }^{140}$

Money became tighter in 1857 when the economy stalled, slowly tightening the noose around Macandrew and his undercapitalised enterprises. In an advertisement, repeated from October to December, twenty-two Otago businessmen, including J. Macandrew \& Co., notified their customers that 'feeling the injurious effects resulting from the indefinite system of Credit which has hitherto existed in this Province- a system alike injurious to the interests both of the buyer and the seller-[they] hereby give notice, that henceforth their terms will be-Quarterly Accounts to be paid in cash within a week of rendering, with non-payers charged $10 \%$ per annum for first three months, $15 \%$ for the next three and $20 \%$ beyond. ${ }^{141}$ Their positive incentive was a 5\% discount for cash. Macandrew had to sue at least one creditor in 1858 when he summonsed Octavious Harwood of Portobello for ' $£ 49$. 2/2 being the balance due to the Plaintiffs upon the annexed items of account. ${ }^{, 142} \mathrm{He}$ was also forced to borrow widely, and at times, illicitly.

\section{DOWNWARD SLIDE}

Macandrew's casual attitude to money, especially that belonging to other people, became public in 1857, when Peter Proudfoot, Chief Commissioner and Treasurer of the Waste Land Board and Factor to the Trustees of the Funds for Religious and Educational Uses, died suddenly. When Proudfoot's successor requested the key to the Board's money chest, Macandrew, as Proudfoot's executor, refused to surrender it. The Chest, when opened was found to contain $£ 705$, not the supposed $£ 1929$, with more than $£ 1200$ missing. Coincidentally, over $£ 1000$ was found in Proudfoot's house which Macandrew impounded and refused to surrender. ${ }^{143}$ Macandrew's explanation was aggressive and critical: 'With regard to the whole amount not having been lodged in the said Chest, I may state that Mr. Proudfoot's habit was to keep the money in his private residence, and that placing it in the Chest at all was the exception, not the rule. I am not sure but that, in so far as safety was concerned, he acted quite right in this. His practice in this respect has been so far beneficial that it has given yourself and friends an opportunity of making what you stood

\footnotetext{
${ }^{140}$ Adam, p. 63; 'Previous to that time trade had been under the dominion of an old Sydney merchant, whose great object was to make money, which he did rapidly. Our young friend [Macandrew] commenced business on an apparently opposite principle, viz., to create a trade...He encouraged the farmers to cultivate more largely. He advanced money on their grain and wool, and in a short time made his influence felt far and near.' ${ }_{141}^{14}$ Ibid., 31 October to 12 December 1857.

${ }^{142}$ Summons: James Macandrew/Octavious Harwood, District Court of Dunedin, undated, HL, MS$0438 / 156$.

${ }^{143} \mathrm{OW}, 14$ November 1857.
} 
much in need of at the time, namely, political capital, and has enabled you so far to divert the public mind from your own and their political delinquencies.' To which the editor of the Otago Witness-William Cutten, son-in-law of Superintendent William Cargill, and now, in the close-knit world of Dunedin, Proudfoot's replacement — added his gloss 'Mr. Macandrew must know that, by affirming that instead of money there are available deposits, he brands his late friend as a defaulter, as no Treasurer has a right to invest the cash of his department in available deposits. ${ }^{144}$ A more tolerant view was taken by the broad-minded Hocken fifty years later who wrote: 'The evidence showed considerable laxity all round, and, but for the honest, God-fearing character of the community, a stronger term might be used. It seemed probable that the money-chest was a convenient receptacle from which several had an opportunity of withdrawing a little money as occasion arose, to be honestly replaced, of course. Any fault lay in detection. ${ }^{, 145}$

The dissolution of the partnership of James Macandrew and Co., on 10 September 1858 suggests that Reynolds, who had managed the business in Dunedin while Macandrew was absent, may have become aware of its shaky finances and decided to resign. A year later, on 15 September 1859, Macandrew sold his 'Store and Auction Departments' to James Paterson and Co. and advised of his intention to confine operations 'to shipping, and to exporting wool, grain, and other produce...All produce passing through our hands will be stored in our floating hulks, either at Dunedin or Port Chalmers. ${ }^{, 146}$ Finally, even the ships had to go, sold with the Melbourne steamship contract, to Frederick Greer on 25 January $1860 .{ }^{147}$

By May 1860 Macandrew had to advertise that 'The Undersigned beg respectfully to request that all DEBTS due to them may be paid forthwith at their Office...Also, that all CLAIMS against them may be lodged with the said J. S. Douglas, by whom the same will be duly paid. James Macandrew \& Co. ${ }^{148}$ All his properties were mortgaged ${ }^{149}$ and then went under the hammer-except Colinswood, ${ }^{150}$ with some land at Carisbrook sold as ' 80 Quarter-Acre Sections...in the newly surveyed Township of Richmond Hill, being part of

\footnotetext{
${ }^{144}$ Ibid.

${ }^{145}$ Hocken, Contributions, p. 182.

${ }^{146}$ OW, 24 September 1859.

${ }^{147}$ Ibid., 3 August 1860.

${ }^{148}$ Ibid., 5 May 1860. He was still trading under the name of James Macandrew \& Co. despite having sold his firm to James Paterson in September the previous year.

${ }^{149}$ Ibid., 27 July 1861. ' $16^{\text {th }}$ August $1860 \ldots$.. I also made over to them three properties in the town, and gave them a second charge on a property on the side of the Harbour... This left me no real property unencumbered.' ${ }^{150}$ Ibid., 26 November 1860, Horse-shoe Bush Run advertised for sale; Ibid., 9 March 1861, Hokanui Run reported sold.
} 
the Carisbrook Estate. ${ }^{151}$ The house and the remainder of the estate were put up for sale on 23 January $1861 .^{152}$

Trotter writes that Macandrew continued to borrow wherever he could: 'from business associates, from his loyal friends, even from his humble clerks. The streets buzzed with rumours of the financial straits of the new Superintendent. ${ }^{, 153}$ Rumours also suggested that the province's financial affairs were suspect; with this view sustained by Macandrew's procrastination in calling together the Provincial Council and his refusal to have the public accounts audited - Council prevailed and the auditors duly reported on the first day of Session XI, 12 December 1860. On opening the Session Macandrew announced his retirement as Superintendent but when the auditor's report was tabled it aroused such suspicion that a Select Committee was appointed. ${ }^{154}$

Macandrew's careless approach to the use of public funds ended his commercial career. His election as Superintendent had given him access to the provincial treasury and on 18 December 1860, the Select Committee on the State of the Public Accounts, Public Funds, \&c., having considered his behaviour, presented its Report. It accused him of misappropriating $£ 1712$ passage money for migrants on the Gala, £1000 for payment for railway plant for the Clutha Coal Field and $£ 1073$. 15s. 4d. from the public account. ${ }^{155}$ Council agreed to request the Governor to remove Macandrew as Superintendent and Speaker Richardson was promptly despatched to Auckland to obtain official authorisation. Macandrew denied the accusations and as was his wont, tried to spread the blame, by attacking John McGlashan, the Provincial Treasurer who had given him access to the money. Macandrew published a long diatribe on 26 December $1860^{156}$ and prorogued the Council on 5 January 1861. On 15 January 1861 he assigned 'all his Personal Estate and Effects, and all surplus monies to arise from the sale of his Real Estates (after satisfying the debts secured thereon) to 'six named trustees' in trust, for the benefit of all and singular the creditors of the said James Macandrew. ${ }^{157}$ By the time Speaker Richardson returned from consulting the Governor about Macandrew's position, accompanied by the

\footnotetext{
${ }^{151}$ Ibid., 10 November 1860.

${ }^{152}$ Ibid., 20 April 1861.

${ }^{153}$ Trotter, Pioneers Behind Bars, p. 39. Macandrew had been elected Superintendent on 3 January 1860.

${ }^{154}$ V. and P., OPC, Session XI, 12 December 1860, p. 8.

${ }^{155}$ Ibid., Appendix, Report, Select Committee on the State of the Public Accounts, Public Funds, \&c., 18 December 1860, pp. iv-xxv.

${ }^{156}$ OW, 29 December 1860. In To The People of Otago, Macandrew did not hold back. This item contains even more personal attacks on McGlashan, on the Speaker, on Messrs Dick and Gillies and the Otago Colonist with passing criticisms of the Select Committee and the Council itself.

${ }^{157}$ Ibid., 2 February 1861.
} 
Government Auditor Dr. Knight with a warrant to enquire into the alleged misuse of funds, Macandrew had been sued by Nathaniel Chalmers for the return of payment for an undelivered flock of sheep, declared bankrupt, arrested and imprisoned on 28 January 1861.

This was Macandrew's nadir. Although he was still Superintendent, he was imprisoned and penniless. In July 1861 he gave a statement to the Supreme Court where he sought a discharge from imprisonment for debt and declared 'I remember telling several persons the state of my affairs in the beginning of 1860. I then stated that I had a surplus of $£ 25,000$ over all liabilities... The balance is now unfortunately on the wrong side to the extent of about $£ 13,000$. To account for the loss of the $£ 38,000$ in one year, I hand in a statement of the actual losses sustained by me in that time, and which no foresight could have anticipated. (Mr. Macandrew here handed in a document containing the various items which went to make up a total loss of $£ 41,900$ within the year 1860), 158

Macandrew was familiar with the Dunedin prison, having successfully tendered for its construction in 1855 when its predecessor burnt down. ${ }^{159} \mathrm{He}$ had been a Visiting Magistrate at the prison, in the Provincial Council's 1857 Estimates Debates he had spoken up for Gaoler Henry Monson and he knew how damp and uncomfortable the prison was. ${ }^{160}$ Now, in a move that has become legendary for its brazenness, when faced with imprisonment as a bankrupt, Macandrew declared his home a prison, using the authority delegated to Superintendents to proclaim any place a common jail. Monson was then instructed, by Macandrew 'to remove James McAndrew, a debtor in your custody, to Caris Brook house within your jurisdiction which I have this day by proclamation declared to be a prison of the province of Otago. ${ }^{161}$ The Gaoler was not happy with this turn of eventshe viewed Macandrew as a desperate character and he warned his deputy Charles Hunter, on duty at Carisbrook: 'I have some reason to believe that all your movements are watched, so that I intreat you never to be off your guard, never loose sight of your Charge not for a moment; and see that every night he is locked up; and, if he sleep on the Basement Story, see that the windows etc are all secure. ${ }^{162}$ Monson need not have worried.

\footnotetext{
${ }^{158}$ Ibid., 27 July 1861.

${ }^{159}$ Robert Gilkison, Early Days in Dunedin, Auckland, Whitcombe and Tombs Limited, 1938, p. 2.

${ }^{160}$ V. and P., OPC, Session VI, 5 November 1857, p. 21.

${ }^{161}$ Henry Monson, Journal, 28 January 1861, p. 316, HL, MS-0088.

${ }^{162}$ Ibid., 28 January 1861, p. 317.
} 
In another bureaucratic contortion, Monson wrote to Macandrew requesting extra staff for this unusual situation. ${ }^{163}$ Monson also asked John Hyde Harris, the Resident Magistrate for extra assistance and received a lawyerly reply: 'The Executive Council cannot help you except through his Honor the Superintendent, so that your application to the Executive is practically neither more or less than an application to the Person whose security you wish ensured. ${ }^{164}$ Lightly guarded, Macandrew continued to administer the province from his home until the Governor dismissed him as Superintendent on 8 March 1861. ${ }^{165}$ He was returned to the Public Gaol two weeks later. ${ }^{166}$

Dr. Knight's enquiry ground on until 7 June 1861 when his report was published. ${ }^{167}$ He found that two of the missing payments had been given to Macandrew but were now misplaced while the third item, the missing cash, had been given to him by McGlashan, although Knight suggested that McGlashan had been tricked into doing so. A reviewing Law Officer in April 1862 went further and stated that 'Mr. Macandrew is not guilty of embezzlement, for he never was a person entrusted with public money. He has not detained money under false pretences. Nor can I find that he has committed any offence that will come within any of the statutory felonies or misdemeanours. But my mind is clear that he has committed an offence for which he may, and should be indicted, malfeazance by a public officer to the injury of Her Majesty's subjects or any class of them, is a misdemeanour in the common law. ${ }^{, 168}$ By May 1862, the Government had given up and Stafford wrote 'The Government consider it undesirable to proceed any further in this matter, which is full of difficulty, and the result of any proceedings would be extremely doubtful. ${ }^{, 169}$ More was to be heard of this case in 1867, when Macandrew was re-elected to his former position of Superintendent and Stafford was again Premier.

Macandrew was detained in prison for his inability to meet his private debts and six months later, on 23 July 1861, appealed to the Supreme Court for discharge. ${ }^{170}$ Here he received scant sympathy - the Judge commented that 'this conduct displayed the greatest recklessness toward his creditors, and his defence to the action by Chalmers was calculated to unnecessary delay....Mr Macandrew seemed to complain of having been ill-treated by 163 Ibid., 31 January 1861, p. 319.

${ }^{164}$ Ibid.

${ }^{165}$ Letter: Macandrew, Superintendent/Robert Chapman, Factor of the Church Trustees, 18 February 1861, Presbyterian Church Archives, Knox College, Dunedin.

${ }^{166}$ Monson, Journal, 21 March 1861.

${ }^{167}$ Otago Provincial Gazette, 7 June 1861, p. 199.

${ }^{168}$ Appendices to the Journals of the House of Representatives of New Zealand, 1867, D-1, p. 37.

${ }^{169}$ Ibid., p. 38. Letter 11, signed by William Fox.

${ }^{170} \mathrm{OW}, 27$ July 1861. 
every one. He had acted in a most unbusiness-like manner in signing documents without reading them, and this reckless course of conduct must leave an unfavourable impression upon everyone's minds...he saw another reason than revenge or vindictiveness for Mr. Chalmers' conduct. That gentleman had been very badly treated, and he wanted if possible to get his money.'

An election was held in May 1861 to elect a new Superintendent and Macandrew made good use of his incarceration, electioneering busily from behind bars. Having published a provocative appeal to The People of Otago in mid-April, ${ }^{171}$ even behind bars, he garnered 189 votes to Richardson's winning 292 while McMaster ran a poor third with 106. ${ }^{172}$ In November, released from prison but restrained from politicking, ${ }^{173}$ he had yet another life-changing experience when he was rescued from a capsized boat on Otago Harbour, and taken to the Provincial Hotel, where 'for some hours lay in a very precarious state. ${ }^{174}$ One of the boathands was drowned.

If 'an intellectually drunken conception of the 'illimitable' resources of the principal colonies was fashionable' in late nineteenth-century Australia, it was equally true of New Zealand in the 1850 s. ${ }^{175}$ Macandrew was one of a small group of settlers who were shrewd enough to grasp the opportunities that lay in an untapped country and were able to exploit its endless resources. The first ten years of his life in Otago were years of unrestrained development, when a steady stream of colonists were matched with an unlimited amount of land, when internal and external markets were ripe for development and when a sharp-witted businessman like Macandrew could skim a commission from almost every human transaction in his locality. Otago was fortunate to be unoccupied by hostile Maori and to possess a geography and a climate which made settlement trouble-free compared to the North Island provinces.

In his pursuit of wealth, Macandrew gambled and lost. He believed that the explosive growth enjoyed at that time would continue forever and he was brought down by hubris. Perhaps it was too early in the colony's life for him to realise that 'thriving colonies are always in or just out of crises. Such emergencies are the symptoms of and the results of

${ }^{171}$ Ibid., 15 April 1861. This was his second Appeal to the People of Otago, following the one of 29 December 1860.

${ }^{172}$ Ibid., 25 May 1861.

${ }^{173}$ Trotter, Pioneers Behind Bars, p. 48: 'It has often been supposed that Macandrew was sequestered there (Colinswood) almost under house arrest, but it cannot have been a very strict arrangement.'

${ }^{174}$ Colonist, 26 November 1861.

175 Brian Fitzpatrick, The British Empire in Australia: An Economic History 1834-1939, Melbourne, Melbourne University Press, 1941, p. xxiv. 
the go-ahead colonial pace. ${ }^{176}$ Macandrew may also have been a victim of an Otago world-view based on the exclusivity of the Presbyterian settlement: isolation and religious conviction were both strengths and weaknesses for Otago. Settlers had to co-operate to survive and their beliefs gave them solidarity but they also produced an unwarranted attitude of superiority and a reluctance to co-operate with the rest of New Zealand. Later, Otago's incredible gold-based wealth provided a freedom to build and develop in peace which was denied most of the other provinces.

Macandrew emerged from these experiences a changed man whose life took a very different course hereafter. As a businessman he had taken excessive risks with his own money and with that of others. He had been immensely successful in taking up investment and logistical opportunities before other settlers and he became the equivalent of a modern-day multi-millionaire. As a politician, he had access to large sums of public money and on two occasions he used it for his own purposes, with the result that he prompted three Provincial Council Select Committees and an investigation by the New Zealand Government. Although his imprisonment was for failure to pay a creditor, he surely deserved, by the laws of the time, to be punished for embezzlement and fraud. That he escaped so lightly is a reflection of the tolerance enjoyed at that time by gentlemen and politicians, and an indication of his formidable ability to debate any issue. He later claimed to have reimbursed all of the amounts misappropriated. ${ }^{177}$ For the rest of his life, he avoided personal scandal although he was widely criticised as an over-enthusiastic borrowand-spend Minister of Public Works in Sir George Grey’s Ministry of 1877 to 1879.

\footnotetext{
${ }^{176}$ William Westgarth, The Colony of Victoria, London, Sampson Low, Son, and Marston, 1864, p. 88.

${ }^{177} \mathrm{BH}, 20$ February 1867.
} 



\section{CHAPTER 4}

\section{Politician: First CAREER 1852-1861}

Macandrew is remembered principally as a politician, whose career extended across three distinct periods of New Zealand history-the establishment of selfgovernment, the abolition of provincial government, and the interlude of George Grey's 1877-79 Ministry - so the remainder of this thesis will focus on his very public political life.

The New Zealand Government Act passed by the House of Commons in 1846 was enlightened: it gave the settlers a voice in government, but proved unwieldy. It divided the colony into two provinces, with European lands further divided into municipalities. ${ }^{1}$ Each province was to have its own governor, a Legislative Council of Crown appointees and a Lower House elected by municipal representatives, which were given extensive powers of self-government including taxation and legislation. The General Assembly of New Zealand which sat above these bodies consisted of the Governor-in-Chief, a Legislative Council of Crown appointees and a House of Representatives elected by the provincial Houses and was responsible for nine areas of national importance. Grey realised that this complicated and quasi-federal edifice for less than 13,000 settlers was unworkable and had it suspended for five years, to the dismay of the settlers whose feelings ran high. Grey's refusal to accommodate settler demands for elected representatives was marked by protests throughout the country followed by the formation of Settlers' Constitutional Associations in Wellington, Nelson, Canterbury and Otago. Even the independent settlers of Auckland met to protest. $^{2}$ While often concerned with parochial matters, the Settlers' Associations were effective vehicles for pursuing wider political change and by 1850 , Grey was faced with opposition throughout the entire country. ${ }^{3}$

Macandrew arrived in Otago brimful of confidence, certain that the Otago Association had secured a Charter and that self-government was on its way, only to discover that Earl Grey had reneged on his agreement and Governor Grey still insisted on

\footnotetext{
${ }^{1}$ An Act to make further provision for the Government of the New Zealand Islands, 9 \& 10 Vict. cap. 103, dated 28 December 1846, printed in The London Gazette, 29 December 1846.

2 A.H. McLintock, Crown Colony Government in New Zealand, Wellington, Government Printer, 1958, pp. 297-301. Opposition to nomineeism was a major plank of the Constitutional Societies; p. 304, the British Colonial Reform Society on which the Settlers' Associations were modelled, aimed at obtaining for each colony 'the real and sole management of all local affairs...including the disposal of waste lands, and the right to frame and alter its local constitutions at pleasure.'

${ }^{3}$ McLintock, Crown Colony, p. 305.
} 
the Crown nomination of appointees to the Legislative Council. Macandrew's political career in New Zealand was launched at this point: he soon engaged with Governor Grey over legislative matters even while he was responsible for gathering the evidence the Otago Lay Association needed to convince Sir John Pakington that the Otago settlers did indeed want a Charter - though a large group of them patently did not. ${ }^{4}$ Macandrew's political career was certainly enhanced by his activities in the Otago Settlers Association where his lifelong habit of driving the business of any forum soon became apparent - he was always prompt to move, amend and conclude business. As an outspoken critic of the Governor's policies, Macandrew staked his claim as a future political leader, aware that the views of the Otago settlers were reaching influential ears in Britain. ${ }^{5}$

As proprietor of the Otago Witness, Macandrew very likely wrote the editorial in August 1852 which identified the ideal colonial political representative and took issue with Grey that there was a lack of experienced settlers capable of serving in political roles, one of the justifications Grey gave for delaying the introduction of an elected assembly. ${ }^{6}$ Macandrew wrote that 'it is very desirable, that they should be men of education at least, if not men of some position and standing in society;- - they ought to be vigorous and energetic, men of business habits and knowledge; and if they should possess a large personal and pecuniary interest in the property of the settlement, so much the better' which as good as announced that he was available to serve. The editorial was published after the passage of the New Zealand Constitution Act in London in June 1852 and can be seen as the opening of Macandrew's election campaign. Unsurprisingly, he was named as an organiser of the celebrations when the Constitution Act arrived in Dunedin on 5 November 1852 - a coincidence which might explain the presence of 'cartloads of old cases, shavings and tar barrels contributed by Messrs. Macandrew, (which) were conveyed to the Church Hill to make a bonfire, the public in all directions contributing wood, old crates, and such rubbish as they could lay their hands on. ${ }^{7}$ Bells were rung, flags were flown, guns were fired and dancing broke out on the jetty.

\footnotetext{
${ }^{4} O W, 8$ February 1851, Petition; McLintock, Otago, p. 317. A petition forwarded by Grey to the Colonial Secretary protested that 'the very name of Class Settlement engenders endless disputes between the different professing parties of Christian settlers, which your Petitioners cannot but regret' and had about 186 signatures.

${ }^{5} \mathrm{OW}, 21$ February 1852.

${ }^{6}$ Ibid., 21 August 1852. Macandrew was a hands-on proprietor of the newspaper; cf. McLintock, Otago, p. 284, fn. 3: 'It is easy to detect the editorials written by Macandrew and Burns as the style of each was so distinctive.'

${ }^{7} \mathrm{OW}, 13$ November 1852.
} 
The New Zealand Constitution Act 1852 comprised 82 clauses and provided a much simpler governance structure than had its predecessor. ${ }^{8}$ Clauses 2 to 31 established six Provincial Councils while Clauses 32 to 69 established a General Assembly comprising the Governor, a Legislative Council and a House of Representatives. Clause 70 authorised the creation of municipalities. The remaining twelve clauses dealt with native law and lands, the responsibility for disposal of waste lands (a General Assembly responsibility), the wash-up of New Zealand Company debts (one quarter of the profit from the sale of Waste Lands to be paid to the Company). Clauses 75 to 78 were specific to the Canterbury, Nelson and Otago Settlements, Clause 80 defined New Zealand's geographical borders and the last two clauses comprised instructions for the proclamation of the Act when it reached New Zealand.

This Act established the Provinces of Auckland, New Plymouth, Wellington, Nelson, Canterbury and Otago, each with a Council of no more than nine members to be elected for a maximum four year term, and a Superintendent elected separately for the same period as his Council. A Superintendent's election could be disallowed, or he could be removed by the Governor if the Council requested, which meant his fate was not solely in the hands of the electors. ${ }^{9}$ Electors had to be male, over twenty one years old, to have possessed a freehold worth $£ 50$ for at least six months or leasehold worth $£ 10$ for not less than three years, or occupy a tenement worth $£ 10$ if in a town or $£ 5$ outside the urban area. $^{10}$

Although the establishment in New Zealand of local bodies with widespread powers to run their own affairs was inherent in both of the Constitution Acts, the eventual Provincial Councils exercised greater powers than envisaged by the Colonial Office and certainly more than British municipal councils possessed, mainly as a result of Grey's intervention. When he promulgated the new law in 1853, Grey reversed the anticipated sequence of events and convened the Provincial Councils before the General Assembly. In March 1853, he usurped Parliament's role by issuing new regulations for the sale of waste lands and reduced the price already set in some of the fledgling provinces. Given the

${ }^{8}$ An Act to grant a Representative Constitution to the Colony of New Zealand, 1852, No. 72.

${ }^{9}$ McLintock, Crown Colony, p. 334: 'Pakington...had his own ideas on the relative importance of the General Legislature and the Provincial Councils, and firmly rejected the theory that the provinces be regarded as independent colonies.'

${ }^{10}$ Ibid., p. 345, fn. 1: 'In 1853, when the first election was held, for every hundred of the population there were twenty names on the electoral rolls. In the United Kingdom at this time the figure was four.' The novel experience of access to political power for most settlers which came with land ownership, and the desire to retain and share it, is a possible explanation of the $100+$ pieces of land legislation passed in the provincial period. 
geographical isolation and the strong parochialism of the settlements, it is not surprising that the Provincial Councils tended to exert authority in more spheres than was intended by the Act's authors while the General Assembly took many years to achieve its projected authority. ${ }^{11}$

The responsibilities of the Superintendent were laid down in Clause 18. He was the Province's head of government who assembled and prorogued the Council: he initiated all money bills, and could give his council drafts of ordinances for them to consider. He could suggest amendments to bills and he also had the power to endorse Ordinances (which then required the Governor's confirming assent) or send them directly to the Governor for approval. Morrell suggests that the Superintendent was 'made in effect a provincial Second Chamber' and the relationship between a Superintendent and his Provincial Council was very similar to that between the Governor and the Legislature until $1856 .{ }^{12}$ Morrell concludes 'in short the Superintendent of a New Zealand province, though of course he played all his parts on a restricted stage, was often able to combine three roles: he had the official dignity of a Canadian Lieutenant-Governor, he performed administrative functions like a provincial Administrator in South Africa, and he was a popular leader, taking part in that capacity not only in provincial but in general politics. ${ }^{\text {'13 }}$

The General Assembly consisted of the Governor, a Legislative Council of nominees appointed for life, and an elected House of Representatives. Appointment to the Legislative Council emulated that of the Life Peers in the House of Lords, but did not contain provincial representatives per se as Earl Grey had desired. ${ }^{14}$ Provincial representation in the Legislative Council would have created a Senate similar to Australia's, adopted in 1901, and could have safeguarded provincial interests more closely but McLintock is definite that a federal government was never intended. ${ }^{15}$ Overall, as Morrell summarises 'The most important principles of the constitution-the generous measure of representative government, the extension and liberalisation of the provincial system, the surrender of control of lands, the power of amendment—were well calculated

\footnotetext{
${ }^{11}$ Gavin McLean, The Governors: New Zealand's Governors and Governors-General, Dunedin, Otago University Press, 2006, p. 56. Governor Browne suggested to the Colonial Office in November 1855 that 'The head start given to the provincial councils by Grey had enabled them to get the better men. Few settlers, he believed, could afford to serve outside their province.'

${ }^{12}$ Morrell, The Provincial System, p. 59.

${ }^{13}$ Ibid., p. 61.

${ }^{14}$ Ibid., p. 64.

${ }^{15}$ McLintock, Crown Colony, p. 347.
} 
to appeal to the colonists of New Zealand. ${ }^{, 16}$ This was to be the system of government of Macandrew's new country where the interplay between provincial and colonial authority was to shape his political career.

\section{Provincial Councillor}

It took almost a year before elections were called on 10 September 1853, whereupon Macandrew nominated Cargill as Superintendent, and was in turn nominated for a seat on the Otago Provincial Council by his later and persistent adversary, William Cutten. ${ }^{17}$ In this election he polled second and proceeded to serve on the Council for twenty two years, all of its existence less two years he spent in disgrace.

Eight of the nine elected Otago Provincial Councillors convened in the Mechanics' Institute Hall in Princes Street on 30 December 1853 for the first meeting of this longsought body and Macandrew was elected unopposed as Speaker of the Council. ${ }^{18}$ In his opening speech, Superintendent Cargill outlined the issues which were to dominate the political life of Otago until 1861, when a new set of challenges arose, following the discovery of gold in the Province and a wave of goldminers arrived. ${ }^{19} \mathrm{He}$ observed that the General Assembly had not been called and that the position of the Council was uncertain as 'objectors in other provinces have raised the question of illegality as to the disposal of public revenue' but he thought 'our policy should be, to take all that is given and use it for the public good, but at the same time under protest against every infraction or suspension of the Constitution in all its fullness.' His priorities were the immediate challenges which faced the isolated Otago settlers who were struggling to eke out a living from the land: to obtain money for Public Works and Immigration, to survey road lines to enable land sales to proceed, to build roads and to continue with the administration of the Otago Block under the Terms of Purchase of 1849. Cargill would appoint a Provincial Treasurer immediately and a surveyor as soon as possible.

Macandrew resigned as Speaker after only three weeks to join the three-man Executive Council, appointed to advise the Superintendent, but by the end of the session, this body had dwindled to one member with 'Mr. Macandrew holding the unique office. ${ }^{20}$ Fifteen bills were presented during the Session, eleven of them by Macandrew on topics as

\footnotetext{
${ }^{16}$ Morrell, The Provincial System, p. 70.

${ }^{17} \mathrm{OW}, 24$ September 1853. Macandrew in turn, nominated Cutten for a Town of Dunedin seat.

${ }^{18}$ Ibid., 7 January 1854.

${ }^{19}$ Ibid.

${ }^{20}$ Hocken, Contributions, p. 155.
} 
diverse as the establishment of an Executive Council, Dunedin public lands, Reserves, Scab and Catarrh, a Government Gazette, Provincial Revenue, an Empowering Bill, Ferries, Dog Nuisance, Land Purchase and Jetties and Wharves. ${ }^{21}$

Members of the Provincial Council disagreed from the start, ostensibly over land prices, but more fundamentally, over the future of Otago. Different philosophies divided the settlers. Cargill's conservative backers - Cutten, Macandrew and Reynolds - wanted to maintain the Terms of Purchase and preserve the special character of Otago while the opposing camp, John Gillies, John Hyde Harris and Edward McGlashan supported Governor Grey's General Land Regulations of 4 March 1853 which had reduced the sale price of land from 20/- to 10/- and in some cases, to 5/- an acre. ${ }^{22}$ Cheaper land meant reduced contributions from land sales for the immigration, education and public works funds. This in turn reduced the Otago Lay Association's ability to select and subsidise the 'right' type of settler and inevitably, undermined the Free Church ethos of the Settlement. Inevitably, some settlers wanted to abolish the Church's control. ${ }^{23}$

The battle lines were drawn when Cutten and Reynolds moved that 'the Council is of opinion that public lands should not be alienated, except at a price that should cover the expense of surveys, and make suitable provision for immigration. ${ }^{24}$ From this time on, Gillies, Harris and McGlashan, in favour of cheaper land and more liberal terms of immigration, voted in opposition to many of the Council's proceedings, which led Cargill to challenge their definition of a councillor's role. He suggested that 'by passing these resolutions the Council have assumed a power which at most they possess in conjunction with the Superintendent. I am therefore to learn on what ground they consider themselves entitled to pass Resolutions not simply assenting to, or recommending a measure, but absolutely enjoining it, and requesting the Superintendant to intimate it to the government. ${ }^{25}$ But the satisfactory definition of the Superintendents' powers was to elude Parliament for most of the life of the provinces. Following Macandrew and Cutten's

\footnotetext{
${ }^{21}$ V. and P., OPC, Session I, 10 January 1854, Summary of Proceedings on Bills, p. vi.

22 John Gillies, 1802-71. Dunedin lawyer, partner of John Hyde Harris. Member OPC 1853-55, Speaker OPC 1854-55.

John Hyde Harris, 1825-86. Son-in-law of William Cargill, Dunedin lawyer, member of Little Enemy, Member OPC 1853-58, Otago Executive Council 1858-59, Superintendent of Otago 1863-65, MLC 185864, 1867-68, Solicitor-General (Stafford Ministry) 1867-68.

Edward McGlashan, 1817-89. Younger brother of John McGlashan, partner Young \& McGlashan, Dunedin merchants, Member OPC 1853-55, 1871-76, MHR 1860-62, 1871-75.

${ }^{23} \mathrm{OW}, 6$ August 1853, 'Report of a meeting held in Dunedin in support of reducing land prices in Otago.'

${ }^{24}$ V. and P., OPC, Session I, 12 January 1854, p. 6.

${ }^{25}$ Ibid, Message Respecting the Intestate Estate Funds, 14 March 1854, p. 22. Cargill was unaware or unsupportive of the role of a Loyal Opposition.
} 
departure for the General Assembly which meant the loss of his majority, Cargill prorogued the Council on 25 April 1854 with a hard hitting, typically blunt speech in which he expressed his frustration with the members who had brought the Council to stalemate and had challenged his authority. ${ }^{26}$ Cargill claimed, excessively, that opposition to his policies was comparable to an attack on human society, but such behaviour was predictable as the new body tested the limits of its powers.

\section{COMPACT OF 1856}

The sale of land occupied all provincial councils throughout the 1850s and Macandrew's contributions to this issue reveal some of his values. Grey's General Land Regulations of March 1853 were translated into the Waste Lands Act 1854 which permitted a Provincial Council to recommend that the Governor issue regulations for the "sale, letting, disposal and occupation" of the Crown lands in any province, and the Provincial Waste Land Act 1854 which allowed the Governor and the General Assembly to delegate powers to the provinces to make laws for the disposal of their own waste lands. ${ }^{27}$ In the Council, Edward McGlashan proposed that a Select Committee be appointed to amend Otago's land laws and reduce their sale price. ${ }^{28}$ Macandrew, committed to the Free Church ethos of the settlement which depended on the continuing sale of land at 40/- an acre, anticipated the report of a stacked Committee, and riposted that the Council should wait until the new and enlarged Council had been elected. He charged 'that there is no call for immediate and hasty legislation on a subject of such vital importance to the future interests of the Province, especially as the regulations presently existing are sufficient to meet present exigencies. ${ }^{29}$ McGlashan withdrew his motion and on 14 November 1854, Macandrew moderated his stance and moved an amendment that permitted genuine settlers to occupy their land on payment of a deposit, reduced the sale price of Bush Land and continued the letting of pastoral leases. He also proposed that the Superintendent take action on the land issue. Gillies challenged the Executive's refusal to commit firmly to any policy on land and threatened to withhold Supply but his action was

${ }^{26}$ Macandrew sailed on 28 March and missed the last seven sitting days of the OPC. He was accompanied by William Cutten and John Cargill on the Government Brig Victory to Auckland which they reached 70 days later, just in time for the first sitting of the House of Representatives; V. and P., OPC, Session I, 25 April 1854, Appendix, Superintendent's Speech of Prorogation, pp. 29-34. Cargill considered that 'Your Council has shown a tendency, not unnatural perhaps, in the novelty of our circumstances, to exceed its proper bounds, and to trench upon the functions of the Executive'; V. and P., OPC, Session I, 25 April 1854, p. 17, Gillies was so offended by the speech that he resigned his seat immediately.

${ }^{27}$ Waste Lands Act 1854, No. 6. Provincial Waste Lands Act 1854, No. 13.

${ }^{28}$ V. and P., OPC, Session II, 10 November 1854, p. 7.

${ }^{29}$ Ibid. 
aimed at a bigger target than the land laws. Gillies wanted the Executive to show some leadership. ${ }^{30}$

Factional in-fighting over Executive responsibility saw Macandrew resign from the Executive Council in November 1854 after only seven sitting days, following strong personal criticism of his lackadaisical behaviour. ${ }^{31}$ Macandrew justified his resignation, and Reynolds', by claiming that they had only agreed to be interim members of the Executive, although Reynolds, never as independent as Macandrew, rejoined the Executive on 23 November 1854 and remained a member until December $1865 .^{32}$

With Macandrew and his commitment to a high land price sidelined, Cargill recommended to Council that sale prices should be lowered and only land in the proclaimed townships or Hundreds be sold, this to continue the pastoralists' occupation and the income from their rents. ${ }^{33}$ New Land Regulations were passed on 12 September 1855 and incorporated Cargill's suggestions that town land be sold by auction, that the price of rural land within Hundreds be 10/- per acre, and purchasers would be required to spend 40/- per acre on improvements in four years. ${ }^{34}$ The existing Government Land Commissioner was replaced by a locally appointed Waste Land Board which arbitrated purchasers' and lessees' claims in an open Court. ${ }^{35}$ The Land Regulations even won approval from the Otago Witness which reported that 'we naturally enough believe the plan adopted in Otago to be the most simple in construction, and as likely to be most effective in working' because it simultaneously maintained control over the quality of new settler who would need a certain level of capital to become a landowner, and land-grabbing graziers would be deterred by the improvement requirement. ${ }^{36}$ Macandrew's contribution to this debate was muted. At this stage in his career he did not exhibit the self-discipline necessary to belong to the Executive. Where negotiation between more reasonable men might have led to a cohesive and effective cabinet, Macandrew was too contumacious and

${ }^{30}$ Ibid., 14 November 1854, p. 9. Gillies: 'before taking into consideration the Appropriation Bill intended to be introduced into the House on Tuesday next, it is necessary that the Executive give satisfactory explanations as to the line of policy they intend to adopt:- On what subjects they intend to introduce Bills this Session.'

${ }^{31} \mathrm{OW}, 25$ November 1854. Macandrew resigned on 23 November 1854. On 14 November Cutten had described Macandrew's approach to politics: 'When Mr Gillies had accused the Executive of having no policy, Mr Macandrew had cheered. He delighted in having no policy, and he admitted the fact.' Reynolds resigned on 17 November.

${ }^{32}$ Ibid., 2 December 1854.

${ }^{33}$ V. and P., OPC, Session II, 12 December 1854, Superintendent's Message No. 6, p. 27.

${ }^{34} \mathrm{OW}, 29$ September 1855. Summary of Land Regulations of the Province of Otago.

${ }^{35}$ McLintock, Otago, p. 395.

${ }^{36} \mathrm{OW}, 29$ September 1855. 
too much of an opportunist to be a team man. Even Cargill had recognised Macandrew's fickleness and appointed Cutten, Gillies and Harris to his Executive Council.

Macandrew's unreliability was compensated by his lateral thinking skills and his problem-solving talents, even if his solutions were not always universally popular. An example of his ability to generate creative (although not necessarily original) solutions to problems emerged in the debates on the Land Regulations when he suggested that the money deposited from land sales be used for loans to settlers. He presented a resolution to the Council in May 1855 which horrified some and earned the support of only one other Member. ${ }^{37}$ That the State could lend money to its citizens was an idea before its time and it demonstrated Macandrew's liberality in economic matters, although he was conservative in social and religious matters. It also demonstrated the speculative side of his personality which, combined with his lack of self-discipline, later led to his misuse of public money. Cutten, more cautious, 'objected to the resolution as erroneous in principle and dangerous in practice...It was a most unwarrantable dealing with the public revenues. It would encourage speculation and encourage the community to invest in lands beyond their means, ${ }^{38}$ and the matter went no further, being voted down by the Council members, including Reynolds, Macandrew's usually loyal brother-in-law. ${ }^{39}$

Despite the new regulations, land sales continued to occupy the Council. Sales stagnated in 1856 and on opening Session V on 2 December, Cargill announced that the Treasury was almost empty and he proposed to sell land outside the Otago Block to fund development as he was entitled to do by the Financial Resolutions adopted by the General Assembly in September 1856. Known as the Compact of 1856, it gave the Provincial Councils the authority to manage all waste land within their province and to retain the revenue from its sales. ${ }^{40}$ Cutten, a conservative regarding land sales, criticised the unwarranted speed with which Cargill was prepared to overturn the fundamental principle of the Land Regulations-restricted sales at a set price which generated funds for the

\footnotetext{
${ }^{37}$ V. and P., OPC, Session II, 7 May 1855, p. 52. Macandrew proposed 'That in the present circumstances of the Province, with abundance of real property, but a scarcity of circulating medium, it is inexpedient and impolitic that the money deposited for lands, under the temporary Regulations for the immediate occupation thereof now in force, should be locked up in the Provincial chest for an indefinite period; and that it would greatly conduce to encourage and aid the efforts of the industrious settlers...were the money so deposited lent out to the individual by whom it has been so deposited-'

${ }^{38} \mathrm{OW}, 19$ May 1855.

${ }^{39}$ V. and P., OPC, Session II, 7 May 1855, p. 52. Rennie supported him, Adam abstained and Reynolds joined Cutten, Harris and Edward McGlashan to oppose him which suggests there was a limit to their liberal views.

${ }^{40}$ Appendix to the Journals of the House of Representatives 1858, B-5, Correspondence Relative to the New Zealand Loan of $£ 500,000$.
} 
Settlement's development. Ignoring Cutten's opposition, the Council moved swiftly to pass the Land Sales and Leases Bill 1856 which divided the original Otago Block into eight Hundreds. This provided land for farmers at 10s. per acre if they spent 40s. for improvements within four years while a further 600,000 acres were made available outside the Block at 10s. an acre in blocks of not less than 2000 acres with no improvement requirement. ${ }^{41}$ Rural land in Otago was now available for purchase at a lower price than previously which led to increased sales and a larger return for the Provincial coffers: the Free Church was able to retain its control. The changes reassured the graziers and encouraged closer settlement and denser population.

In 1858, the General Assembly superseded all provincial Waste Lands legislation in an attempt to control immigration and to prevent monopoly land holdings. The Waste Lands Act 1858 authorised the Governor to delegate the sale and administration of all Crown Lands 'into the hands of any other party' which had been the case since $1856 .{ }^{42}$ The Act reduced the maximum size of lots for auction to 320 acres - from the existing 2000 - set an upset price of 5/- per acre, forbade the sale of land on credit and vested responsibility for the administration and disposal of waste lands throughout the colony in the Governor, who could alter the price of land at the request of a Provincial Council. ${ }^{43}$ Otago Councillors responded that 'The Council deems any exercise of the power to raise the price of land in this Province at present unnecessary ${ }^{44}$ but despite their declaration, the sale of rural land was failing to raise sufficient money for the Province's needs. In 1859 it was proposed to amend the Otago Land Regulations, to remove the improvement requirement within the Hundreds. ${ }^{45}$ This lapsed, and Macandrew, who was constant in his efforts to retain the distinctive elements of the Class Settlement, when elected Superintendent, expressed his satisfaction with the existing Regulations and blocked any change.

\footnotetext{
${ }^{41}$ Schedule and Synopsis of the Ordinances passed by the Provincial Council of Otago during Sessions I, 1853-4, to XXVII, 1870 Inclusive, Dunedin, 1871, p. 21. Land Sales and Leases Ordinance 1856 assented to 27 January 1857.

${ }^{42}$ V. and P., OPC, Session VII, 3 November 1858, Superintendent's Opening Address, p. 1.

${ }^{43}$ The Waste Lands Act 1858, No. 75, passed 19 August 1858.

${ }^{44}$ V. and P., OPC, Session VII, 7 November 1858, Reply to the Opening Address of His Honor the Superintendent, p. 5.

45 Ibid., Session VIII, 26 October 1859, Appendix, Proposed Additions to and Amendments of the Land Regulations of the Province of Otago, New Zealand, p. i.
} 


\section{EDUCATION ORDINANCE 1856}

From the inauguration of the Council, Macandrew pursued three particular matters with fervour: immigration, steamship services and the provision of educational facilities. Education was to become one of Macandrew's lifelong passions and his actions in this area reveal much about the man and his values.

The provision of superior, universal, Christian schooling in the Settlement of Otago had been highly touted by its Scottish promoters but their promises were scarcely fulfilled. Little money had been provided for education in the first five years and teachers relied on fees and public subscriptions. ${ }^{46}$ Macandrew believed that Parliament should provide adequate funds but 'the whole apportioning of the money, the management of the schools, and the nature of the education should be under the absolute control of the various Provincial Councils.' To his mind, Otago was a Presbyterian theocracy and he considered it a sine qua non that the Bible and the Westminster Shorter Catechism should be taught in the schools. ${ }^{47}$ Accordingly, early in the life of the Council, Macandrew introduced the subject which was to occupy his political career: his motion on 8 March 1854 marked the beginning of the huge investment of time and energy he was to devote to educational matters which culminated in the establishment of the University of Otago. ${ }^{48}$

Macandrew moved 'that it is the opinion of the House that it will be conducive to the best interests of the Province that an Educational Institution, or High School, be established in Dunedin, over which there shall be at least two Teachers, who shall be competent not only to teach all the higher branches of a liberal education, but to train others for the profession of Teachers throughout the rural districts of the Province.'

Education was one area where Councillors worked together for the good of the province and Macandrew's motion was agreed without debate. An Advisory Committee convened by Macandrew was appointed 'to consider what provision shall be made, and what steps shall be taken to effect that object. ${ }^{49}$ Nine months later the Committee recommended 'that provision should be made from the public funds of the Province, or by assessment, for providing a liberal education to the whole children of the Province as far as

\footnotetext{
${ }^{46}$ McLintock, Otago, p. 374.

${ }^{47} \mathrm{OW}, 1$ October 1853.

${ }^{48}$ V. and P., OPC, Session I, 8 March 1854, p. 13.

${ }^{49}$ Ibid. On this Committee, usual opponents were in agreement: Gillies, Harris and Reynolds, Macandrew (Convener) and the Speaker, Anderson.
} 
practicable' but was noncommittal about what should be taught. ${ }^{50}$ It added 'that this House is of opinion that permanent provision for such education should be made by special Ordinance... of this House, setting down...the character of the education to be provided, and the mode in which such provision is to be made.' It also recommended the establishment of a grammar school to prepare pupils to enter university, with provision to employ six teachers who would be selected on the recommendation of the Government School Inspectors for Scotland, and the Rectors of Free Church Normal Schools in Edinburgh or Glasgow, and have their passages to Otago paid by the Province. A scale of teachers' salaries was listed. But it was more than a year before an Education Ordinance was presented for consideration on 5 March 1856, and passed its Third Reading on 18 March. $^{51}$

It was never a popular Ordinance as the choice of religious instruction was left to the school committees, which could be stacked. Cargill's Provincial Executive controlled the Central Board of Education and appointed staunch Presbyterians who ensured that the Westminster Shorter Catechism was the only text used. The settlers objected promptly to its limited choice of religious instruction, to the poll tax it imposed, to the lack of local control over the school committees and to the expense to the Province. The Provincial Councillors objected too when they realised that they had no control over the Central Board and the organisation of the system. Macandrew returned as Speaker in January 1856, no longer permitted to promote legislation and although supporting the Ordinance, even he considered the system was too costly and he criticised the building of an expensive High School and masters' houses. ${ }^{52}$

Cutten attempted unsuccessfully in 1856 and 1857 to amend the Education Ordinance and reduce the powers of the Central Board. ${ }^{53}$ Harris tabled an amendment in $1858^{54}$ which was not accepted although he did stir Cargill to table an Education Bill in 1859. ${ }^{55}$ This bill lapsed so it was Macandrew, now Superintendent, who bowed to popular demand and sponsored a new Education Bill in 1860 which received assent in July 1861,

\footnotetext{
${ }^{50}$ Ibid., Session II, Appendix. Report of Committee on Education, Adopted December 18, 1854, p. 89.

${ }^{51}$ Schedule and Synopsis of the Ordinances passed by the Provincial Council of Otago during Sessions I, 1853-4, to XXVII, 1870 Inclusive, Dunedin, 1871, p. 13.

${ }^{52} \mathrm{OW}, 5$ November 1857: 'Mr Macandrew thought that a High School for Dunedin in the present circumstances of the Province was a useless and extravagant expenditure, and the building at present in use might have answered the purpose very well for some years to come.'

${ }^{53}$ V. and P., OPC, Session V, 10 December 1856, p. 26. V. and P., OPC, Session VI, 9 November 1857, p. 31.

${ }^{54}$ Ibid., Session VII, 12 November 1858, p. 19.

${ }^{55}$ Ibid., Session VIII, 25 October 1859, Superintendent's Address, p. 3.
} 
after his departure. It converted the Central Board of Education to a Board of Education controlled by the Provincial Council, broadened the options for religious instruction, abolished funding by rating and finally launched the High School. ${ }^{56}$ This establishment, for boys only, was opened on 3 August $1863^{57}$ but it took until 1871 to realise another Macandrew goal, a High School for girls. The primary force behind the establishment of the Girls' High School was Learmonth Dalrymple who agitated vigorously for at least seven years to win Macandrew and other Councillors to her cause. ${ }^{58}$ Education was debated vigorously in every session of Macandrew's first period as a Provincial Councillor and his quest to make Otago's system the best and most accessible in the colony was to occupy him for the remainder of his life. Macandrew was a product of the rigorous and egalitarian Scottish education system who had prospered in New Zealand, and he was determined that all children would receive at the very least the same opportunities that he had.

The wrangling between the Superintendent's faction and the Opposition bloc over the familiar issues of public works, immigration and land sales, was an extension of the demarcation dispute over the powers of the Superintendent, the Executive Council and the Council members and the future of Otago. The dispute saw sittings of the second session of the Council last from October 1854 to September 1855 when the dissident bloc of Gillies, Harris and Edward McGlashan, joined by Cutten who had parted company from Macandrew at the previous year's General Assembly, voted together throughout the session. ${ }^{59}$ By July, having committed to a larger Council and a revised Electoral Roll, the members were unsure whether they were any 'longer a legally constituted Legislative Body' and were waiting for the Governor's dissolution. ${ }^{60}$ The Council ended on 26

\footnotetext{
${ }^{56}$ McLintock, Otago, p. 386.

${ }^{57}$ Ibid., p. 509.

${ }^{58}$ Ibid., p. 511.
}

Learmonth Dalrymple 1827-1901. Born in Scotland, migrated New Zealand in 1852. She also successfully lobbied for women's admission to the University of Otago which was approved in 1871, the first in Australasia to do so and was active in the kindergarten movement.

${ }^{59}$ McLintock, Otago, p. 361. McLintock claims that the fighting was actually over Cargill's trust in Macandrew to the exclusion of Cutten, his own son-in-law. Harris, another Cargill son-in-law, added fuel to the flames when 'With prophetic insight he held that the administration of public affairs should not be entrusted to a man whose whole public career had been marked by extreme rashness, inconsideration for others and a determination to achieve his own ends. No one panted for power more than Macandrew and no one was more unwilling to part with it.'

V. and P., OPC, Session II, 1854-55. Macandrew and Reynolds voted together in 13 of the 15 recorded divisions and opposed each other only once. Gillies and Harris never voted with Macandrew.

${ }^{60} \mathrm{~V}$. and P., OPC, Session II, 6 August 1855, Superintendent's Message No. 18, p. 69. Cargill said that he had asked for the dissolution on 4 May 1855. 
October 1855, most unusually, when Governor Browne granted its members their request for a dissolution which was followed, uniquely, by a wiping of the official record. ${ }^{61}$

In the election held in December 1855, Macandrew, despite his earlier behaviour on the Council, easily won his seat for a second time as one of the three Central District members representing the Taieri, by right of his position as a landowner and grazier at East Taieri. ${ }^{62} \mathrm{He}$ sat as Speaker for the next four years, and relinquished it only to become Superintendent. Rarely a good committeeman unless chairman, and usually eager to be close to the source of power, if not to be the very source, it is possible that a year on the backbenches after his resignation from the Executive Council in November 1854 had left Macandrew frustrated. During his years as Speaker, his previously idiosyncratic behaviour in the Council became more biddable. The Council regularly moved into Committee of Supply to debate Appropriations for the provincial budget where Macandrew, permitted to vote as a Councillor, displayed no discernible voting pattern. $\mathrm{He}$ was increasingly occupied by his business activities, especially his ships and his immigration agency, and other public duties. ${ }^{63}$

During this period the provinces of the Middle Island developed their infrastructure in peace, untroubled by the conflict occurring between Maori and settler in the North Island, and, more importantly, they were not taxed to pay for the North Island's problems. The scope of provincial council business was clearly delineated: making and administering laws "for the Peace, Order, and good Government of each Province" which included all matters that were one step above the municipal responsibilities of rates, roads, potholes and sewage ${ }^{64}$ Perennial issues - land sales, public works, immigration, law and order, and education-were dealt with thoroughly, even if the outcomes did not satisfy all members.

In Otago, there was no objection when the Superintendent's role was considered important enough to warrant a salary increase from $£ 300$ to $£ 400 .{ }^{65}$ The Council even adopted some of the trimmings of the General Assembly when Mr. John Shepherd was

${ }^{61}$ Ibid., 26 October 1855, Appendix, p. 74: 'NOTE. The Journals of Council from $17^{\text {th }}$ September, to $20^{\text {th }}$ October, 1855, inclusive, are deleted in terms of resolution of $17^{\text {th }}$ March, 1856, in consequence of the Council having been dissolved by His Excellency the Governor immediately previous to the first mentioned day.'

${ }_{62} \mathrm{OW}, 8$ December 1855. Macandrew was the highest polling of five candidates on Election Day, 1 December 1855, with 28 votes.

${ }^{63}$ Macandrew was elected to the Dunedin Town Board in August 1855 and to the Waste Land Board in September 1856. Membership of both Boards allowed him to manipulate events in a way that supported his business interests but were uncovered at Proudfoot's death.

${ }^{64}$ Constitution Act, 1852, clause 18. The Dunedin Town Board had been elected in August 1855 to maintain urban infrastructure.

${ }^{65}$ V. and P., OPC, Session IV, 12 March 1856, p. 13. 
appointed Sergeant-at-arms to the Council. ${ }^{66}$ His services were soon required when Speaker Macandrew indicated that unruly behaviour which had occurred in the Council Chambers must be stopped. ${ }^{67}$ Later in 1856 , Councillors were officially notified of the discovery of gold in Otago but its significance was discounted by authorities who struggled to envisage a world that was to be transformed by the discoveries of $1861 .{ }^{68} \mathrm{By}$ 1858 so few matters required attention that the Superintendent opened Session VII with the words 'I have been under the necessity of calling you together at this time as the Constitution Act has required you to be assembled, in order to be within one year of your last Session. ${ }^{69}$

\section{New Provinces ACt 1858}

In 1858, the General Assembly passed an act which seriously impinged on the authority of the Provincial Councils. The New Provinces Act, 1858 gave power to the Governor 'on certain conditions, but wholly irrespective of the general wishes of any Province...to break up such Province into separate portions. ${ }^{70}$ Otago Councillors responded that 'it is with extreme regret that the Provincial Council of Otago finds itself called upon to record its opinion that by the "Waste Lands Act," and the "New Provinces Act," principles are established which may possibly in future be attended with injurious consequences to the Provinces. ${ }^{, 71}$ It was left to Cargill to articulate, somewhat circuitously, the issue that was to dominate the provincial scene, and Macandrew's political career until 1877, when he declared that 'with reference to these Acts, and the whole tone of recent legislation, showing a desire for centralisation, and the abolition of the Provinces as such, there is much to be maturely reflected on by the Government and Provincial Council, as well as by the people of Otago at large, with a view to such action as may be found

\footnotetext{
${ }^{66}$ Ibid., 12 March 1856, Reply to the Opening Address of His Honor the Superintendent, p. 12.

${ }^{67}$ Ibid., 14 March 1856, p. 18: 'Resolved that the Provincial Solicitor be requested to prepare and introduce an Ordinance, for the purpose of providing a remedy against any misconduct of individuals not members of this Council.'

${ }^{68}$ Ibid., Session V, 2 December 1856, Superintendent's Address, p. 1.

${ }^{69}$ Ibid., Session VII, 3 November 1858, Superintendent's Address, p. 1. These years had the shortest sittings in the Council's existence. The Council held three Sessions in 1856 of $1,9 \& 7$ days. In its life of 34 sessions, the Council's longest session was 65 sitting days, its shortest 1 sitting day and the median length of sessions was 19 sitting days.

${ }^{70}$ Ibid., p. 2.

${ }^{71}$ V. and P., OPC, Session VII, 15 November 1858, Appendix, Report of the Select Committee on the New Provinces Act, 1858, p. 39.
} 
expedient. $^{72}$ The two Acts were early ripples presaging the abolition tsunami which engulfed the Provinces nineteen years later.

Peter Proudfoot, Executive Councillor and Chief Commissioner of the Waste Lands Board, died on 14 October 1857 and events after his death resulted in the Superintendent being reprimanded by the Council for exceeding his powers while Macandrew's behaviour became the focus of a Select Committee. ${ }^{73}$ Macandrew's offence, in covering up a discrepancy in Proudfoot's accounts by refusing, as his executor, to hand over the key to Proudfoot's money chest, resulted in a Council reprimand. The Report strongly criticised Macandrew and demanded the return of a sum of missing money. ${ }^{74}$ This particular defalcation had its conclusion in the New Year when it was reported that 'the deficiency in the Chest on the $28^{\text {th }}$ of October was $£ 1224$. On the $29^{\text {th }}$ of January, just four months afterwards, a sum of $£ 114511$ s $1 \mathrm{~d}$ was paid to Mr. Logie, the Sub-Treasurer of the General Government, leaving a deficiency of nearly $£ 100 .{ }^{, 75}$ No reference was made to the probability of public money being used for short term borrowing, a Macandrew specialty, and the Select Committee handed responsibility to the Superintendent for retrieving the lost money. Nothing more on this matter is recorded in the Council Proceedings.

A year later, Macandrew again demonstrated his propensity for financial risktaking, and his fondness for making spontaneous claims that were often unsupported by either research or his colleagues. In November 1858, the Provincial Treasurer having announced that 'the total revenue was estimated at $£ 54,000$ and the expenditure at $£ 72,000$. Thus it would be seen that there would be a considerable deficiency of funds.' Despite this warning, Macandrew proposed that 'this large, rich, and beautiful Province might borrow $£ 100,000$, or any sum, however great, and he had no fear of the Governor sanctioning their borrowing any reasonable sum. ${ }^{76}$ Council, despite misgivings, agreed to introduce a bill to

\footnotetext{
${ }_{72}^{7}$ Ibid., 3 November 1858, Superintendent's Address, p. 1.

${ }^{73}$ Ibid., Session VI, 3 November 1857, p. 11. Cargill exceeded his legal authority by appointing his son-inlaw Cutten as Proudfoot's successor, to the position of Chief Commissioner of the Waste Lands Board which Macandrew chaired, without the support of his Executive. Cargill's second offence resulted in a reprimand approved by all the Councillors except his son, John Cargill, which stated 'That this Council strongly disapproves of His Honor the Superintendent delivering an Address to the Council without the concurrence of his Executive.'

${ }^{74}$ Ibid., Session VI, 16 November 1857, Appendix, Report, Select Committee on the State of the Land Office, pp. 52-80.

${ }_{75} \mathrm{OW}, 20$ March 1858.

${ }^{76}$ V. and P., OPC, Session VII, 9 November 1858, p. 12.
} 
obtain 'power to borrow money to meet the deficiency of the revenue during the year ${ }^{, 77}$ but a Debentures Bill which was introduced a week later sank without trace. ${ }^{78}$

In contrast to a preparedness to spend up large on public amenities Macandrew opposed payments to individuals from the public purse and in Council his votes repeated his Parliamentary voting pattern: he considered that citizens who undertook civic duties should do so at their own expense. ${ }^{79} \mathrm{He}$ opposed paying fees to the Waste Lands Commissioners, ${ }^{80}$ and he opposed the appointment of Provincial Surgeons because 'everyone should support their own doctor, or, in cases of absolute poverty, the public charity should pay for such humane services. ${ }^{81}$ This propensity continued throughout his public life and is at odds with his tendency to accept rewards from the public purse. ${ }^{82}$ It is consistent, though, with his view that individuals, and provinces, should pay their own way and not depend on external support - a view that underlay his vigorous and abiding support for the provincial system.

\section{Member of PARliament}

During his three decades in the New Zealand House of Representatives, Macandrew initiated many useful practices, based on the thorough knowledge of parliamentary procedure he acquired during long hours spent observing in the House of Commons. In 1853, in the absence of anyone who was prepared to invest the cost and time required, Macandrew was persuaded by his fellow settlers to stand for the House of Representatives and was elected unopposed. ${ }^{83} \mathrm{He}$ was a Member of the House for thirty years, belonging, by a quirk of parliamentary timing, to all of the first nine Parliaments, although in the first decade he attended at Auckland only twice - he absented himself in 1855, 1858 and 1860 and Parliament did not meet in 1857 and 1859. He spent a further ${ }^{77} \mathrm{OW}, 20$ November 1858.

${ }^{78}$ V. and P., OPC, Session VII, 1858, Table IV, Summary of Proceedings on Bills, p. xiv.

${ }^{79}$ Ibid., Session VII, 9 November 1858, p. 12. Macandrew's opposition to the payment of Members evaporated once he was in power, perhaps because he needed all the friends he could get; Ibid., Session IX, 26 April 1860, p. 36, Message 14 included his request for payment of Country Members, and Council voted to pay ' $10 \mathrm{~s}$ per day and 1s per mile each way, for members residing beyond four miles from Town, from commencement of business.'

${ }^{80}$ Ibid., Session VII, 11 November 1858, p. 18.

${ }^{81} \mathrm{OW}, 20$ November 1858.

${ }^{82}$ Hocken, Contributions, p. 329. Throughout his career, Macandrew attended a large number of banquets held in his honour and accepted gifts, for example, Grey River Argus, 8 December 1866. Presented with a 'purse of sovereigns' by the Clutha electors; $O W, 28$ July 1877. Presented with a Testimonial and 1500 sovereigns on 20 July 1877 by the grateful citizens of Otago for his services as Superintendent; Ibid., 25 November 1882. Presented with a gold watch and chain on 17 November 1882 by the appreciative electors of Port Chalmers.

${ }^{83}$ Letter: unsigned, to James Macandrew Esq., JP, 20 September 1852 (mistakenly labelled-it should be 1853), HL, Flotsam \& Jetsam, Vol-02, No 039. 
four years in the wilderness after his imprisonment, returned to the House in 1865 and remained a member until 1887.

On the commencement of proceedings on 24 May 1854 he moved that each session start with a non-denominational prayer; ${ }^{84}$ he promoted the printing of Parliamentary speeches from its first years ${ }^{85}$ and he advocated standardised sitting hours in the House. ${ }^{86}$ He was a notable member in a House of strong characters: he was underestimated then and has been overlooked by historians since. As a clever and calculating parliamentarian, he became a notable powerbroker who only just failed to become premier, but his impact on Parliament during its first decade was limited-he attended only three of its first ten sessions.

Macandrew's attendance at the General Assembly demonstrated the extensive commitment of time required of the original members of parliament, for travelling and sitting. Dedication was also required-while Macandrew was absent, his second daughter, Jane, was born on 26 May 1854 and Eliza had to cope on her own with the three young children until his return. He left Dunedin on 28 March and returned on 8 October: in that period, Parliament sat from 24 May to 16 September. ${ }^{87}$ Nor was there any guarantee of payment although members did award themselves $£ 1$ per day for expenses.

A fellow parliamentarian described Macandrew as 'a keen Scotch Storekeeper, and Elder of the Kirk' and the 70-day voyage to Auckland would have allowed him to have renewed his friendship of London days with Edward Gibbon Wakefield who boarded at Wellington. ${ }^{88}$ Sewell subsequently described Macandrew as 'expectant of office under Wakefield.' Wakefield's reputation made him a dominant figure in the proceedings of the House where members were slow to find their feet and he instigated the defeat of James FitzGerald's Ministry which was followed by a prorogation. Macandrew's association with Wakefield probably secured him the Governor's approbation and a seat in the succeeding clean shirt ministry of Thomas Forsaith, an amalgam of appointed officials and elected

\footnotetext{
${ }^{84}$ New Zealand Parliamentary Debates, 26 May 1854, p. 4.

${ }^{85}$ Ibid., Vol. 50, 10 November 1884, p. 496.

${ }^{86}$ ST, 15 February 1888.

${ }^{87} \mathrm{OW}, 14$ October 1854

${ }^{88}$ McIntyre, W.D., ed., The Journal of Henry Sewell 1853-7. Vol. I. Christchurch, Whitcoulls Publishers, 1980, p. 484, 9 April 1854 \& Vol. II, p. 57, 16 July 1854.
} 
members which governed from 31 August to 2 September, as the shortest-lived government in New Zealand's history. ${ }^{89}$

The first Parliament was rumbustious and conflicting attitudes to land sales and responsible government split the members as the basic rules of procedure were hammered out. Macandrew's controlling personality emerged with his putting the first ever motion in the House, which sought an adjournment. ${ }^{90} \mathrm{He}$ was responsible for the first division of Parliament with his motion that it is fit and proper that the first act of the House of Representatives shall be a public acknowledgment of the divine being, and a public supplication for His favour on its future labours. ${ }^{91}$ Dr. Lee responded by requesting that 'the House of Representatives be not converted into a conventicler, and that prayers be not offered' while Wakefield reassured his colleagues 'that the dread entertained by some members of a State Church being set up if the House engaged in prayer was, he thought, entirely unnecessary.' Macandrew's motion was carried and New Zealand's Parliament still opens with a prayer read by the Speaker.

Macandrew usually spoke early and succinctly in debates and in his desire to hasten business, he was swift to second motions, commit bills and move adjournments. He was adamant that rules must be followed, although in future years he became increasingly casual about parliamentary procedures. In a typically blunt speech espousing responsible government, Macandrew demanded that the Ministry be appointed by the Assembly, not by the Governor and asserted that 'if there were not men in that House qualified and, if need be, ready to make personal sacrifice in order to conduct the government - the people of New Zealand were not ready for free institutions, and the Constitution Act had been conferred too soon... He would take any number of members of that House in preference to an equal number of men who had not undergone the same ordeal of election., ${ }^{92}$ Macandrew later reversed his position on responsible government which he had so vehemently promoted on 2 June, most likely to ensure that the Governor and the House supported his stand on maintaining a high price for waste land in Otago.

With the sale of waste lands a major issue which occupied much of Parliament's time, Macandrew insisted that any changes to the sales regulations be implemented with

\footnotetext{
${ }^{89}$ So called because Forsaith insisted on returning home to change his clothes before accepting his nomination as a Member of the Executive Council.

${ }^{90}$ NZPD, 24 May 1854, p. 2.

${ }^{91}$ Ibid., 26 May 1854, p. 4.

${ }^{92}$ Ibid., 2 June 1854, p. 32.
} 
the proper authority but revealed his provincial bias when he stated: 'While disapproving of what he could not but consider as an evasion of the Constitution Act, he at the same time felt that the waste lands would be best administered by the Provincial Legislature, and that the General Assembly ought at once to apply for power from the Imperial Parliament in order to enable it to hand over the waste lands, on such terms and conditions that it might then see fit. ${ }^{93}$ He criticised members who opposed Acting Governor Wynyard and he declared that he was prepared to wait for Wynyard to receive the proper authority from Britain to establish responsible Government. ${ }^{94} \mathrm{He}$ began as he was to finish, an adamant supporter of the provinces until they expired in 1877.

In the last weeks of the first Parliament, Macandrew revealed his conservative fiscal values. He thought it one of Parliament's duties to regulate public expenditure 'because it was evident, if they had no power over the expenditure, it might be all spent in salaries. ${ }^{, 95}$ Macandrew originally opposed payment to members although he admitted that 'the arguments brought forward had changed his opinions. But, still, he would go no further than paying members their actual expenses' and he believed that 'members of the Legislative Council should be men of property: if not, they ought not to be there.' He spoke against granting a pension to the widow of a civil servant, he opposed a Supreme Court for Otago, and even opposed increasing a subsidy to enable a coastal steamer to include Otago in its itinerary. However, he was clear about the responsibilities of government and it was reported 'Mr. Macandrew said there were about three hundred Natives in the province of Otago and he was anxious to get $£ 100$ or less to help to establish an industrial school there' which he obtained, and he also supported the appointment of a clerk for the Colonial Treasurer. At this time, he was fiscally cautious and politically conservative, but with time, he became more sympathetic to people of limited means although he remained throughout, impatient with the slowness of government procedures.

Parliament gave Macandrew a platform and the opportunity to shape his political values. He emerged as an impatient pragmatist, eager to complete business and move on, often changing allegiances to achieve his goals. At this stage he supported a united colony with the provinces acting as units of local government, not as units in a federal system, although he reversed his stance later. Parliament was an excellent place to form networks of acquaintances and friends and to garner useful business advice but it was not

\footnotetext{
${ }^{93}$ Ibid., 11 July 1854, p. 190.

${ }^{94}$ Ibid., 15 August 1854, p. 332.

${ }^{95}$ Ibid., 6-14 September 1854, Supply in Committee, pp. 378-442.
} 
sufficiently important or useful for him to return for the 1855 Session. News that the British Government had granted permission for a fully responsible ministry drawn from the General Assembly was not circulated in time and few parliamentarians bothered to travel north in 1855. No Otago members attended. Attendance at the General Assembly was expensive, time consuming and often considered unimportant by many members, given the limited range of topics it handled and its limited authority. In 1858, Macandrew again absented himself, claiming pressing business matters to justify his absence.

Macandrew's major contribution to the 1856 session of Parliament, based on his Otago experience, was his motion to repeal the existing laws governing banks and currency and the need to pass uniform banking regulations which would permit the incorporation of banking companies authorized to issue their own banknotes. He claimed that 'the practical effect of the law as it then stood was to cramp and paralyse commerce, and to discourage that spirit of enterprise which so largely distinguished the Anglo-Saxon race. Another evil was that the law enabled one bank to secure a monopoly, ${ }^{96}$ and he lobbied successfully for the Bank Paper Currency Act. The other major outcome of this session was the passing of the previously cited Waste Lands Act 1856 which was disallowed but reappeared as the Waste Lands Act $1858 .^{97}$

In this session, Macandrew crossed swords for the first time with the man who was to become his nemesis, the centralist Premier Edward Stafford, when he criticised the first financial statement of Stafford's Ministry. ${ }^{98}$ In a long speech, Macandrew opposed the proposal to borrow $£ 500,000$ to pay off the government debt to the New Zealand Company and the Union Bank of Australia and to buy native land, not because he opposed borrowing but because it would create a national debt that was 'not for the purpose of being expended on public works, or in any way of promoting the progress of the colony, but to be frittered away at the hands of the General Government. ${ }^{99}$ Macandrew also objected to Stafford's proposal to retain all customs revenue for central government even though the quid pro quo was to give all land sales money to the provinces. The loan was approved and the Land Compact was agreed-the provinces kept three-eighths of their customs revenue and the land sales revenue-after his departure. Macandrew and most of

\footnotetext{
${ }^{96}$ Ibid., 2 May 1856, p. 39.

${ }^{97}$ Waste Lands Act 1856, No. 22; Waste Lands Act 1858, No. 75.

${ }^{98}$ Edward Stafford, (Sir), 1819-1901. Landowner, Superintendent Nelson PC 1853-56, MHR 1855-78, Premier 1856-61, 1865-69,1872, KCMG 1879, GCMG 1887.

${ }^{99}$ NZPD, 19 June 1856, Pp. 180-83.
} 
the southern members had departed Auckland on 9 July, six weeks before the session ended.

Membership of Parliament was obviously important to Macandrew as he resigned his seat in 1858 to avoid dismissal for non-attendance at the session of that year. He stood again and was re-elected unopposed, while a timely dissolution of Parliament in 1860 avoided his dismissal for non-attendance that year. Through a combination of overcommitment, financial insecurity, disinterest and punishment, he did not attend any sittings from 1856 to 1863.

\section{SUPERINTENDENT}

Cargill was too ill to attend the Provincial Council on its Opening on 25 October 1859 so the Clerk read his Address to the Council which included his official resignation, whereupon Macandrew promptly read it to them again. ${ }^{100}$ Members, many of whom disliked and did not trust Macandrew, would have been distressed if they had realised this event foreshadowed the next phase in Macandrew's career - that he would open the next three Sessions of the Council, as Superintendent in his own right.

William Cargill was 65 and judged old on his arrival in Otago in 1848 and he had led the Settlement during eleven years of extreme hardship. He has been described as authoritarian, unsympathetic to constitutional government, and inclined to favour his family in political matters. McLintock considers that 'in no sense therefore, was Cargill an original thinker or daring innovator' which says much for the Otago settlers' need for a strong leader. ${ }^{101}$ But the need for such a chief had passed. Speculation about Cargill's successor began immediately and, unsurprisingly, it was the perpetually ambitious Macandrew who had sufficient enthusiastic supporters to allow his nomination to be advanced well before the next Session of Council. ${ }^{102}$ Worldly, self-confident, devout, popular with working folk, a prosperous entrepreneur and now, a proven politician, Macandrew's personality was the opposite of Cargill's. Macandrew's attributes matched the mood of the times and he was seen as a suitable leader for the next chapter of Otago's existence.

News of his nomination was greeted with horror by a few. One editorial, most likely written by Cutten, was alarmingly prescient when it stated:

\footnotetext{
${ }^{100}$ V. and P., OPC, Session VIII, 25 October 1859, Superintendent's Address, p. 3; OW, 29 October 1859.

${ }^{101}$ See McLintock, Otago, p. 415 for an acerbic description of Cargill's character.

${ }^{102}$ Lyttelton Times, 30 July 1859.
} 
we fail to discover in the whole of that career anything that is deserving of commendation, either in the Provincial Council or the General Assembly. In the first and most important session of the latter body, he supported a weak, miserable, faction, under Mr. Wakefield, with no adequate public motive, and at the last, he was absent when his vote might have been of consequence. In the Provincial Council he has never taken an active or originating part. On political grounds, therefore, we do not see that he has either claim or qualifications to justify his election to the Superintendency. As a Settler, he may have been useful and enterprising, as our contemporary saysspeculative and rash we should rather call it - but his qualification on these matters, however, may occasionally serve for mercantile business, are dangerous characteristics in a Superintendent...The gentleman is also a very large contractor with the Government, to sums amounting to nearly the whole last year, and almost half of the public revenue of this year: some $£ 24,000$ of the public money pass through his hands. Is it proposed for a moment that he should be Superintendent, and contractor to this extent...A Superintendent may have investments and be a runholder or a freeholder, but it would never do to have a merchant actually engaged in business... We have great objections to the gentleman proposed. We believe that in some respects a more unfit person could not be found. ${ }^{103}$

Macandrew's behaviour in the next year, as a businessman and as Superintendent justified this trenchant piece. By 1861, his critics would have been dismayed by the accuracy of its forecast.

Nomination Day, 5 January 1860, was an anticlimax as Macandrew was the only candidate and was declared duly elected. ${ }^{104}$ Only then did he expound on his platform and gave his views on the "three leading topics-Immigration, Education, and the Price of Land. ${ }^{105}$ He considered that immigration 'should only be limited by the means within ourselves of providing the new comers with food until such time as they could grow sufficient for themselves.' On education, it was his opinion 'that it was the duty of the State to see that its youth are all educated, and that the means of education shall be brought within reach of, if not even forced upon all...He trusted therefore, that no sectarian prejudice-no niggardly economy-would be brought to bear upon this most vital question.' Finally, regarding the price of land, 'he was perfectly satisfied that the existing Regulations, on the whole, were the best in New Zealand and one of his first official acts would be to get an authoritative opinion as to their validity.' He also 'thought we had begun at the wrong end in spending so much on metalled roads, when it was clear that railways had been found in all countries to be the cheapest roads that had been made.'

103 OW, 23 July 1859.

${ }^{104}$ McLintock, Otago, p. 417.

${ }^{105} \mathrm{OW}, 7$ January 1860. 
Furthermore 'he would approve of borrowing money to deepen the harbour, and reclaim it from the Jetty to Grant's Brae.'

Macandrew was aged 40 when he was elected to the leadership of Otago and was typical of the first tranche of Superintendents who 'went through the whole gamut of the colonist, pioneering, business, journalism and public affairs, and speedily took a leading part in the life of the province. ${ }^{106}$ To outward appearances he was a highly successful, affluent businessman, an owner of ships, shops, farms, livestock, newspapers and an imposing home for his growing family. ${ }^{107} \mathrm{He}$ belonged to a prosperous and influential extended family and had been an outspoken and useful voice in Otago politics. Although he had had little impact in colonial politics despite his membership of New Zealand's second Ministry he was considered to have influence in the upper echelon of society. Dr. Hocken considered him to 'have troops of friends; he was genial, generous, impulsive, ready to assist any one in distress, contributed always and liberally to any object and took an active and principal part in public affairs' a view which is reinforced by a contemporary report of his meeting with settlers in the Tokomairiro District just a month after his election. $^{108}$

A cavalcade of fifty settlers on horseback met him and presented an address which indicated his important place in their affections, telling him that 'many of us cannot forget the kindness you manifested and the assistance you afforded your fellow-settlers in their earlier struggles, when you, as a private merchant, so nobly encouraged private enterprise; while you co-operated in public matters with Capt. Cargill as the head of the settlement; you stimulated and supported the weak but well disposed. ${ }^{109}$ Macandrew, always ready to share his vision for the province, told them that there were 'two or three things connected with the Tokomairiro which he might mention' and expressed 'his desire to see a railroad from west to north, and by one great trunk line to unite both ends of the Province.' He also

${ }^{106}$ Scholefield, Guy, A Dictionary of New Zealand Biography, Wellington, Department of Internal Affairs, 1940, Vol. I, p. 99. Early Superintendents who had successful business careers were William Brown (Auckland Supt. Mar-Sep 1855) and his partner John Logan Campbell (Auckland Supt. Oct 1855-Sep 1856), Charles Brown (Taranaki Supt. Jul 1853 — Dec 1856), Isaac Featherston (Wellington Supt. Jul 1853Apr 1858 and Jun 1858-Mar 1871), Edward Stafford (Nelson Supt. Aug 1853-Sep 1856) and James Fitzgerald (Canterbury Supt. Jul 1853-Sep 1857).

Serving in the General Assembly may have improved Macandrew's electability as Superintendent-22 $(50 \%)$ of the total 44 sat in the General Assembly before becoming Superintendent.

${ }^{107}$ Macandrew's eleven children were born over a period of 20 years. Two died at birth and nine survived him: Colin, 1849-1928; Marion, 1851-1925; unnamed, b/d 1852; Jane, 1854-1940; unnamed, b/d 1855; James, 1857-1927; Herbert, 1859-1917; Hunter, 1862-1952; Alice, 1864-1927; Mabel, 1867-1957; Arthur, 1869-1950.

${ }^{108}$ Hocken, Contributions, p. 196.

${ }^{109}$ Wellington Independent, 16 March 1860. 
wanted to make Lake Waihola navigable, appoint a Bench of Magistrates in the district and establish a troop of yeomanry in the volunteer corps. Only those who dealt with him at close quarters, and especially those who had financial dealings with him, knew of his unreliability, and few were prepared to criticise him publicly.

Macandrew's behaviour at this time was unusually subdued and he surprised many people by the moderation and pragmatism of his programme when he opened Session IX on 11 April 1860. ${ }^{110}$ His opening words were reassuring: 'Gentlemen, it is not my intention, nor that of my advisers, to initiate much in the way of legislation during the present session. It is an easy matter to load the Statute Book with Ordinances...let us aim at having few laws, and those only of a practical nature... The principal business of the session will be the disposal of the public money. ${ }^{111}$ His proposals were prudent, necessary and promising: reorganise the Survey and Public Works Departments, sell debentures to raise $£ 50,000$ for Immigration, expedite steam navigation on inland waterways, build a telegraph between Port Chalmers and Dunedin, impound stray cattle, regulate the sale of alcohol, enlarge the Council, build quarantine facilities at Bluff, lift salaries of heads of departments, fund the harbour master adequately, provide access to an Asylum, explore the hinterland of the province, establish a High School, resolve the grievances of the Southern settlers to avoid a breakup of Otago and finally, to sort out the Land Regulations. Even the Budget was balanced. The Councillors were supportive and Cutten could only criticise the quality of the bills presented because 'they appear to us to be crude, undigested measures, and the greatest misfortune which could befal the Government, would be for the Council to pass them as they stand.'112

It is possible that the poor preparation of the bills was a reflection of Macandrew's lack of attention to detail, compounded by a shortage of skilled administrative staff to service the Provincial Council and the absence of cohesion in his Executive Council. In a move that demonstrated Macandrew's disregard for protocol, he had appointed Thomas Dick, John McGlashan and William Purdie as his Executive Council without Council approval and before it met. ${ }^{113}$ In the absence of common aims, and working with a Superintendent as independent as Macandrew, it is unsurprising that the Executive did not

\footnotetext{
${ }^{110}$ OW, 14 April 1860.

${ }^{111}$ V. and P., OPC, Session IX, 11 April 1860, Superintendent's Address, p. 2.

${ }^{112}$ OW, 14 April 1860.

${ }^{113}$ Lyttelton Times, 1 February 1860.

Thomas Dick, 1823-1900. Dunedin merchant, Member OPC 1859-65, Otago Executive Council 1859-60, 1862-64, Otago Superintendent 1865-67, MHR 1860-63, 1866-67, 1879-84.
} 
endure. He then appointed a new Executive within a few weeks-Dick, James Howorth, William Tarlton, Frederick Walker, and most surprising of all, Macandrew's chief critic, William Cutten. Macandrew then demonstrated an unexpectedly cooperative spirit, which caught the Witness unawares and moved it to comment: 'We were not prepared to find that his Honor would so completely accede to the wishes of the Council as to make so thorough a change, and so far it augurs well of the future. ${ }^{114}$ But the major issue that overshadowed Otago in 1860, and which was resolved after Macandrew's dismissal, was the demand for a separate province in Southland and despite vigorous opposition in Dunedin, Southland became a Province by Order in Council on 25 March 1861. It came into existence on 1 April 1861 and survived until 5 October 1870 when Macandrew had the pleasure of welcoming the Southerners back into the Otago fold. ${ }^{115}$

Public dissatisfaction with Macandrew's performance as Superintendent emerged in September 1860 in another editorial, also likely to have been written by a now vindicated Cullen. It was prompted, no doubt, by knowledge that an audit of the public accounts had been undertaken and that the Council would soon receive an interim report. ${ }^{116}$ The editorial also admonished Macandrew for missing the General Assembly in Auckland that year.

Undeterred by public disapproval and having failed to attend the General Assembly where his vote might have prevented the implementation of the New Provinces Act, Macandrew's opening address on 12 December 1860 left his audience speechless. ${ }^{117}$ Given the suspension of land sales for the previous eight months and the consequent reduction in provincial income he considered that 'it is a matter for congratulation, and exhibits very forcibly the healthy and buoyant position of the Province financially that there should be any balance at all in the hands of the Treasurer. ${ }^{, 18}$ This was followed by a list of the not inconsiderable number of roads and bridges built or improved since last session, noted the paddle-steamer service initiated on the Taieri River and the one planned for the Clutha River, detailed the area of land surveyed and noted the 2,532 immigrants landed-making a population of 13,000. Then he dropped his bombshell, with his statement that 'the chief business of the Session will be to consider, and I trust to assent to, propositions on the part

\footnotetext{
${ }^{114}$ OW, 28 April 1860.

${ }^{115}$ Scholefield, Parliamentary Record, p. 224.

${ }^{116} \mathrm{OW}, 15$ September 1860 . The Report was delivered on 24 October.

${ }^{117}$ McLintock, Otago, p. 410. On 12 October 1860 T.B. Gillies introduced a Bill to suspend the New Provinces Act. It was lost by one vote on its Second Reading.

${ }^{118}$ V. and P., OPC, Session XI, 12 December 1860, Superintendent's Address, p. 1.
} 
of government, involving works of great magnitude, and tending towards the rapid development of the boundless resources of this province.'

This was a speech made for foreign consumption in which Macandrew the booster emerges: he would have known that the conservative Otago settlers were unlikely to be impressed by his oratory but it could inspire potential migrants on the other side of the world, and it would distract attention from his financial problems. Macandrew's list of Think Big projects makes him a forerunner of State intervention in the development of infrastructure in New Zealand. Other provinces were investing in large projectsCanterbury's railway tunnel and Nelson's civic buildings-but Macandrew's exceeded them. His schemes required huge investment by the Provincial Government; they preceded Julius Vogel's borrow-and-build schemes of the 1870s, and they prefigured his own later activities as Minister of Public Works in 1877 and $1878 .{ }^{119}$ He justified the investment simply with these words 'if Otago is to be the meridian - the starting point, as it were - the thing must of necessity be started by the Government, inasmuch as no private company can possibly be found to take the matter up' and used arguments familiar to modern ears to sell his case. 'If, afterwards, it should be deemed advisable for the Government to relinquish the practical conduct of the undertaking, there will be no lack of private companies ready and willing to take it off our hands at a premium.' In his confident manner, he presented this as fact without identifying any private companies waiting to rescue the province.

He wanted the Province to reclaim twenty-two acres from the harbour-the cost of $£ 33,000$ would be funded by loans, then the land would be sold for $£ 72,000$ - and to provide employment. ${ }^{120}$ He proposed the building of a new main road to Central Otago. He suggested that the establishment of a Panama Route between Great Britain and the Australian Colonies 'can be done without it costing any one a sixpence in the shape of taxation, and without borrowing one single farthing.' It would be paid for by declaring one sheep-run a Hundred, selling the land for intensive farming and constructing three steamers to carry mail, specie and passengers and if you say the word, I am prepared to undertake that the vessels shall be built and on the berth within nine months from this date.'

${ }^{119}$ Wright, R.E., 'Bank ownership and lending patterns in New York and Pennsylvania, 1781-1831', Business History Review, 73 (1999) quoted in Belich, Replenishing the Earth, p. 203. "Boosterism was infectious, and you had to catch it to keep up with the competition. 'He who confined his transactions, in those times, to his actual capital could stand no chance with his neighbours who availed themselves of loans."

${ }^{120}$ V. and P., OPC, Session VIII, 25 October 1859, Superintendent's Opening Address, p. 2. Macandrew was not original as Cargill had suggested the reclamation project previously. 
He wanted to introduce salmon into New Zealand rivers and he proposed the development of fishing as both an important source of food for New Zealanders and as an export business.

Having dazzled and distracted his listeners with his vision, Macandrew announced his exit plan: 'It now only remains for me to say a single word personal to myself, which is, that circumstances will, I fear, render it expedient for me to devote my attention to personal affairs, and that this is probably the last Session of the Provincial Council which will be opened by me.' To which, the flabbergasted Council could only reply 'the various measures suggested by your Honor for the advancement and continuance of that prosperity will receive the most serious attention and consideration of the council, when submitted to it in detail. ${ }^{, 21}$ Councillors little imagined that with the discovery of gold in the following year, Otago would be in a position to afford his proposals and eventually, would invest in far greater works than Macandrew now envisaged.

The Provincial Auditor's Report tabled in the Council on 12 December 1860 listed four items where amounts appeared to have been misused. It also told the Superintendent that 'we are impressed with the necessity for a change in the Audit system, which we consider far from satisfactory;' ${ }^{122}$ Macandrew's inattention to details and a hint of deceitful dealing had landed him in strife again and for the third time in his Council career, a Select Committee enquiry was launched, directed 'to examine into the state of the Public Accounts, Public funds, and general financial position of the Province, with power to call for persons, papers, books, accounts, and documents ${ }^{123}$ This ensured that witnesses had to appear before the Committee. Macandrew refused to appear to be questioned ${ }^{124}$ at which the Council denied him access to the evidence, and refused to allow him to 'be heard by counsel at the bar of the Provincial Council., ${ }^{125}$

The Select Committee reported back a week later and accused Macandrew of misappropriating $£ 1712$ passage money for migrants on the Gala, $£ 1000$ for payment for

\footnotetext{
${ }^{121}$ Ibid., Session XI, 19 December 1860, Reply to the Opening Address of His Honor the Superintendent, p. 14.

${ }^{122}$ Ibid., p. 9. The Report is in Appendix 1, Reports of Auditors of Public Accounts, p. i.

${ }^{123}$ Ibid., Session XI, p. iv.

${ }^{124}$ Letter: James Macandrew to T.B. Gillies, Chairman of the Select Committee, 15 December 1860, HL, F \& J-Vol. 02, No. 05: 'In reply I beg respectfully to decline appearing before the Committee, and most indignantly to deny the allegations referred to...If the Committee chooses to furnish me with a copy of the evidence on which their assertions are founded. Together with the precise charges themselves, I have no doubt of my ability to disprove them.'

${ }^{125}$ OW, 29 December 1860.
} 
railway plant for the Clutha Coal Field and $£ 1073.15$ s. 4 d. from the public account. ${ }^{126}$ The Report described the Gala payment as 'an irregular and improper transaction... while the substitution of another warrant...they are obliged to characterise as only an evasion of the impropriety, which meets neither the moral nor legal necessities of the case' and concluded: 'Your Committee confine themselves to a simple narration of what they have ascertained to this point; will offer no suggestions on what appears to them a grave and serious breach of public trust, but leave it to the Council to deal with this matter as it shall think fit.' Macandrew responded promptly: his Message No. 1 denounced the Select Committee: 'the sole object of which appears to be to prove that the Superintendent has devoted certain private moneys to his own private purposes. ${ }^{127}$ Then, typically, he resorted to ad hominem attacks on his critics and closed with: 'The Superintendent would only add in conclusion, that assuming the object sought by the promoters of the Report to be, to get rid of him officially, that object will be attained in due course, without the public business being longer suspended, inasmuch as he has firmly decided upon relinquishing the office, as stated at the conclusion of his Opening Address, a decision which is confirmed by the insult to the office which has been exhibited by the Council in their delaying or declining to reply to that Address.'

A day later the Council composed a petition to the Governor, accusing Macandrew of using 'a portion of the Public Funds for private purposes' and requested his removal from the office of Superintendent of Otago. Ironically, the Council then had to present an Address to the Superintendent asking him to forward the Memorial to the Governor. ${ }^{128}$ Macandrew's riposte in Message No. 2 accused the Provincial Treasurer, John McGlashan, of confusing and misusing money from the Provincial, the General Roads Board and his own private accounts, while he, Macandrew knew nothing about the provenance of the money. ${ }^{129}$ Macandrew then lamented that the Provincial Council could 'stigmatise a man (on the eve of his voluntary retirement from office), who has devoted the best ten years of his life to the interests of the Province.' The Council would not let the issue rest and their response to Message No. 2 summarised their frustration with Macandrew: 'If the allegations against the Provincial Treasurer be true, the Committee considers it was His Honor's duty to the State, irrespective of any considerations of friendship, to have shielded

\footnotetext{
${ }^{126}$ V. and P., OPC, Session XI, 18 December 1860, Appendix, Report of Select Committee on the State of the Public Accounts, Public Funds, \&c, pp. iv-xxv.

${ }^{127}$ Ibid., 19 December 1860, p. 12.

${ }^{128}$ Ibid., p. 15.

${ }^{129}$ Ibid., 20 December 1860, Superintendent's Message No. 2, p. 15.
} 
the Province from any chance of injury by the unlawful use of the Public Moneys. ${ }^{, 130}$ Macandrew made matters worse by not apologising and going quietly, and he provoked the Council further by publishing a long, self-justifying appeal, To the People of Otago, in which he lashed out at Treasurer McGlashan, Speaker Richardson, Messrs Dick and Gillies and the Otago Colonist, with passing criticism of the Select Committee and the Council itself. ${ }^{131}$

Speaker Richardson was despatched to Auckland to present the Memorial to the Governor and in January 1861 the Council resumed work on the estimates, roading, bridge building, ferries, keeping the Sabbath holy, the Southern problem, education, and the Trans-Tasman steamer subsidy. Despite the bad blood between them, the Superintendent continued to communicate with the Council, making his requests and sending his responses in the seventeen messages he transmitted during the session. In his final message he gave his assent to the Appropriations Ordinance 1860-61 and acknowledged that Council had had its revenge: 'Understanding that there is no other business to be taken up by the Council during the present session-which (looking at the important measures initiated by the Government) he very much regrets' he announced his intention to prorogue the Council the next day. ${ }^{132}$

Then, not unexpectedly, justice caught up with Macandrew on 28 January 1861 when he was arrested and imprisoned for a personal debt. He promptly proclaimed Carisbrook to be a gaol and continued his work as Superintendent from there until he was dismissed on 8 March 1861. He remained in his home until 21 March 1861, when he was returned to the Public Gaol. Macandrew's defeat in the May election for his replacement marked the end his first political career.

Macandrew's social status meant that his membership of both legislatures was virtually automatic, especially given his commitment to responsible government, and he appears to have accepted the positions as a duty. However, Macandrew's erratic behaviour in both Houses suggests an ambivalent commitment to his electoral duties, even a preparedness to ignore their rules and obligations while he pursued his business career. Even as Superintendent, he followed his own agenda. In the formative years of the colony's government there were few men who had the knowledge and income to attend sittings and it took very serious lapses of behaviour to have a gentleman ejected from these

\footnotetext{
${ }^{130}$ Ibid., 20 December 1860, p. 17

${ }^{131} O W, 29$ December 1860.

${ }^{132}$ V. and P., OPC, 4 January 1861, Superintendent's Message No. 17, p. 38.
} 
positions of authority. It is no surprise that his peers on the Council who knew him well distrusted him, with a contemporary describing him as 'silvery, cunning, and not overscrupulous,' but many of the remaining settlers responded to his friendliness, his lack of condescension and his preparedness to challenge the established order. ${ }^{133}$

${ }^{133}$ Dr. J. A. Menzies, (later Superintendent of Southland Province), Journal, 7 December 1855, Otago Settlers Museum. 



\section{ChAPTER 5 \\ Politician: Second CaReer 1863-1876 Otago}

The events of 1861 produced an enduring change in James Macandrew's behaviour. His dismissal from the Province's highest office for defalcation, his imprisonment for bankruptcy, the loss of his fortune and a near drowning were sufficiently Damascene to see him reject commercial life and turn to full-time politics. Despite his record, and to the amazement and horror of the Colony, in June 1863 Macandrew won a seat on the Otago Provincial Council, and in July 1885 he was re-elected to the General Assembly. He further confounded his critics by regaining the Otago Superintendency in February 1867 and retaining it for ten years. In the twenty-four years following his political comeback, from 1863 until his death in February 1887, he attended all sessions of the Otago Provincial Council and the General Assembly where he was outspoken and polarising, unswervingly promoting a manifesto of continuous immigration, ongoing land sales and settlement, non-stop infrastructure development, and the submission of central government to provincial rule.

The next two chapters examine Macandrew's second career in politics, from 1863 to 1877 when he fought to prevent the abolition of the provinces. In this period the economy of Otago boomed following the discovery of gold and the subsequent population surge meant substantial infrastructure development was required urgently. When re-elected Superintendent, his principal concerns were that the people of Otago should profit from their own labour and resources and that they should control their own destiny, but as the pressure for abolition of the provinces mounted he became preoccupied by the effort to save them. His task of guiding the Province through this difficult period was not made easier by a Council becoming increasingly reactionary and recalcitrant which in turn made his utterances more animated, varied and even absurd. In Parliament during this period his opposition to Stafford and his support for subsequent Premiers, Fox, Waterhouse and Vogel, provided him with a national platform and country-wide publicity. These worlds were so different and Macandrew's endeavours so divergent that each arena demands a separate chapter to tell his story. Chapter five will consider three phases of Macandrew's political life in Otago - his return to the Provincial Council; his accomplishments as Superintendent from 1867 to 1871 , and his performance as Superintendent from 1871 to 1876 - a record of his political life under extreme duress. Chapter six will recount his behaviour in Wellington in the same period. 
In the $1860 \mathrm{~s}$, the Colony's attention was on settlement and development. More efficient communication, a stagnant economy and a growing awareness of the high cost of government focused attention on the country's political structure and stimulated a period of introspection as the quest for a better and cheaper model of governance continued. During the early 1870s a growing number of politicians attempted to transfer all legislative authority to the General Assembly while leaving regional administration in the hands of smaller, local government units. Resistance to change came from committed provincialists who offered a variety of increasingly radical plans to preserve the provinces: plans which ranged from federation to secession. The battle of provincialism versus centralism was spirited, with regular skirmishes at both local and national levels and Macandrew, a vigorous leader of the provincialists, had his views and actions widely reported throughout New Zealand.

Macandrew's values gave his life consistency and predictability but it is arguable whether they were distinctly Scottish as many were the common values of any settler society. Success in the colonies required a strong work ethic, capital and a degree of business acumen. His Scottishness emerges in his Presbyterian commitment to literacy and his utilitarian belief that a good education helped all citizens to prosper. ${ }^{1}$ Where he was exceptional was in his unremitting commitment to the provinces and Macandrew's position on these will be compared with his contemporary who eventually destroyed them. Julius Vogel was possibly his closest political colleague in the 1860 s, a provincialist politician who shared many of Macandrew's views on development, but who, as Premier Vogel, engineered the abolition of the provinces: this led to their estrangement. ${ }^{2}$ They had much in common: as Vogel once claimed 'anyone who knows me must recognise in me a member of the working class. I have known what it is to want, and I have always had to depend entirely upon my own personal industry; and those who wish to know what facilities this country affords to working men may be told that whatever position I hold I

\footnotetext{
${ }^{1}$ Anderson, R. D., Education and the Scottish People 1750-1918, p. 49, suggests that 'The churches valued schools as a way of retaining their members' loyalty, training the young in their traditions, and evangelizing among the poor.'

${ }^{2}$ Julius Vogel, (Sir), 1835-99, arrived Dunedin 1861, wrote for Macandrew's weekly newspaper the Colonist, established the Otago Daily Times, NZ's first daily newspaper 1861, Member OPC 1863-69, Otago Executive Council 1866-69, MHR 1863-76, 1884-89, Colonial Treasurer (Fox Ministry) 1869-72, Colonial Treasurer (Waterhouse Ministry) 1872-73, Colonial Treasurer (Fox Ministry) 1873, Premier 187375, 76, Postmaster-General (Pollen Ministry) 1875-76, Colonial Treasurer (Stout Ministry) 1884 and 188487, Agent-General, London 1876-80, CMG 1871, KCMG 1874.
} 
owe entirely to my own industry. ${ }^{3}$ His financial situation mirrored that of Macandrew and both recognised the great opportunities available to them in New Zealand.

Vogel and Macandrew were beneficiaries of the British Empire, born in Britain and members of the white, educated middle class who had no buttressing inheritance and had to survive on their wits. Vogel, like Macandrew, was a man on the make: both were men who valued and unashamedly boosted their new country. Their goal was the optimal exploitation of New Zealand's resources and governance structures were merely one means to that end. They initially agreed on the necessity for the provinces but when Vogel became Colonial Treasurer in 1869, then Premier in 1873 and responsible for the Colony's economy, he had to take radical action to reduce expenditure. He engineered the abolition of the provinces when they obstructed the economic recovery of New Zealand.

On occasion, Macandrew admitted that the provinces could not last forever yet he supported them to the end and as a leader of the last-ditch battle to prevent abolition, his actions were constrained by this belief. ${ }^{4}$ Contemporary accounts paint him in reactionary colours and his behaviour at times was immoderate but he was a pragmatist who accepted change. As early as 1866, while campaigning for the Clutha seat in Parliament, he admitted that 'my idea is that increased population, railways, and electric telegraphs will in due course efface the Provincial system, and my policy is to make the most of Provincial Governments as long as they exist, and until the progress of the Colony shall enable us to dispense with them. ${ }^{5}$ His view of the provincial system throughout his career was not consistent and at different times he supported a federated New Zealand of self-taxing provinces and a system of provincial governments supporting a strong central administration. When Vogel launched his public works and immigration plans in 1870, managed predominantly from Wellington, Macandrew endorsed them enthusiastically as he saw the advantages to the provinces, even at the loss of some autonomy.

With their election to the Otago Provincial Council in 1863, they discovered they shared a commitment to colonial development and a similar approach to making politics work for their own benefit. Macandrew became a role model for Vogel. Macandrew, sixteen years older than Vogel, was a risk-taker who readily changed tactics and allegiances, and it was Macandrew's template of provincial borrowing to fund development that Vogel later employed at a colonial level. When Vogel became Colonial

\footnotetext{
${ }^{3}$ Speech: Julius Vogel at Complimentary Banquet, Odd Fellows Hall, 17 February 1876, ATL, MSY-1337.

${ }_{5}^{4}$ Morrell, The Provincial System, pp. 157, 168.

${ }^{5} \mathrm{BH}, 8$ February 1866.
} 
Treasurer in 1869, a pessimistic commentator posted this warning: 'It is true that $\mathrm{Mr}$. Vogel has had the advantage of sitting at the feet of Mr. Macandrew for some years while conducting the provincial business of Otago, but his Government cannot be said to have afforded unmixed satisfaction to the people of that province, the noble resources of which make it so hard to make mis-government acutely felt. ${ }^{6}$ Vogel later acknowledged Macandrew's influence, and admitted that 'I learned a very great deal of that which I have put to useful purposes afterwards during the time to which he referred, when I was his responsible adviser. ${ }^{7}$ It was an enduring friendship which survived their later political fallings-out.

\section{Otago Provincial Council}

In 1861, following the sale of Carisbrook, Eliza and their five children moved to Colinswood, the family farm on the harbour side of the Otago Peninsula which had escaped the fire sale. ${ }^{8}$ Here Macandrew returned on his release from prison, without capital or other assets, and with his reputation tarnished. As he was an undischarged bankrupt on probation, he was barred from commercial pursuits. ${ }^{9}$ A few friends stood by him: in the Provincial Council Alexander McMaster proposed unsuccessfully that an item in an appropriations schedule entitled "'Defalcations of James Macandrew, Esq, £1,012 14s 5d.," be changed to "Deficiency "unexplained' by James Macandrew, Esq.,", 10 and he would have felt vindicated to read that his proposal to initiate a mail route to Great Britain via Panama, ridiculed when he was Superintendent, had been taken up by the Council. ${ }^{11}$

Macandrew was unable to resist the lure of politics and in April 1863 he applied to have his name returned to the Electoral Roll for the Seat of Bruce. ${ }^{12}$ In May 1863, following the expiration of his probation, he was nominated for the seat of Port Chalmers

\footnotetext{
${ }^{6}$ Nelson Examiner, 12 May 1869.

${ }^{7}$ OW, 23 December 1882.

${ }^{8}$ Last Will and Testament of Eliza Hunter Macandrew, signed 11 December 1874, ANZ, Dunedin, DAAC D239 23 435. Eliza's Will exposes the trail of Macandrew's financial irresponsibility - as a Marriage Settlement he agreed to buy her a $£ 1000$ Life Assurance policy on himself - this lapsed. In 1851 he bought her ten acres of land but sold it in 1860 . Her brother W.H. Reynolds bought it back and held it in trust for her. This was sold in 1861 and the money invested in cattle for Colinswood. In 1864, part of the Colinswood Estate was purchased by her trustees with $£ 1000$ from her mother which was to be 'free from the debt control or engagements of my present or any future husband', finally putting the family home beyond the reach of Macandrew's many creditors. In 1868 Eliza bought more land to extend the Colinswood Estate.

${ }^{9} O W, 18$ September 1875: 'Four years' probation was the time imposed upon the young merchant.' It is uncertain when his debts were paid or by whom, to enable his discharge from his bankruptcy.

${ }^{10}$ Ibid., 9 November 1861. Schedule of Unauthorized Expenditure During the Financial Year 1860-61, Appropriations Ordinance 1860-61.

${ }^{11}$ WI, 7 February 1862.

${ }^{12} \mathrm{OW}, 19$ April 1862 . No records exist for the property which he would have owned there to be a voter.
} 
by residents who wanted an expansionist-minded member to represent them on the Provincial Council, now that the discovery of gold had vastly increased the province's coffers and its opportunities for expansion. Macandrew's nomination was greeted with horror in the local press. Vogel, who was virulently opposed to Macandrew's return, wrote 'if ability and genius are other names for consummate cunning and deceit, for trickery and falsehood, for unmeasured audacity and assurance, then is Mr. Macandrew entitled to be dignified with the titles. ${ }^{13}$ Despite the critics, on 1 June 1863 he easily defeated sitting Councillor Thomas Tayler by 27 votes to $11 .{ }^{14}$ Macandrew's success provoked outrage throughout the Colony and a sarcastic observation in another newspaper was unwittingly prophetic: 'We see no reason why Mr. Macandrew should not again be a member of the General Assembly, a member of the Executive Council of the Colony, and Superintendent of Otago., 15

From his arrival in Dunedin in 1861, Vogel had used his position as editor of the Otago Daily Times to promote his view of complete separation of Otago from the rest of the Colony. ${ }^{16}$ In 1862 he was an organiser of a public meeting in Dunedin attended by at least a thousand people who resolved that separate governments should be established for the North and Middle Islands. ${ }^{17}$ Vogel stood for both local and colonial parliaments, but was defeated for an Assembly seat in April 1863, and in May for a city seat in the Provincial Council. ${ }^{18}$ In June he was elected to the Council for a country seat and in September he won a Dunedin seat in the House. When the Council opened in August 1863, it was unsurprising that the thrusting 'New Iniquity' Vogel and the seasoned 'Old Identity' Macandrew should clash. ${ }^{19}$

In October, Macandrew, who at that time supported decentralisation of power rather than complete separation of the provinces, moved in Council to vest the 'executive powers of the General Government, so far as their exercise related to Otago, in officials residing within the province' which was defeated on the grounds of giving 'too large powers to the Superintendent. ${ }^{, 20}$ Its dismissal suggests that Macandrew's misdemeanours lived on in his colleagues' minds and the prodigal was not welcomed back. But his

\footnotetext{
${ }^{13}$ ODT, 28 May 1863.

${ }^{14}$ Ibid., 1 June 1863.

${ }^{15}$ Canterbury Press quoted in ST, 19 June 1863.

${ }^{16}$ Dalziel, p. 44.

${ }^{17}$ ODT, 12 May 1862. The meeting was held on 10 May.

${ }^{18} \mathrm{OW}, 6$ April 1899 . The Assembly seat was won by William Reynolds.

${ }^{19}$ Dalziel, p. 35.

${ }^{20} \mathrm{OW}, 10$ October 1863.
} 
political career was fully rehabilitated two years later when his experience in government and his political skills, coupled with his optimism and enthusiasm for development were acknowledged and his past failures were conveniently ignored. In July 1865 he was returned to Parliament.

In a speech at Port Chalmers in January 1865 Macandrew presented both sides of the separation case and asserted that 'although the dismemberment of the colony is altogether at variance with my inclination, and subversive to all the aspirations of the past - at the same time, if its integrity is to be maintained at the expense and to the detriment of this Province - then I say, perish the integrity of the Colony.' However, he continued, disingenuously 'it seems to me that the destiny of Provincial Government is as yet far from being fulfilled, and that until the country is colonised and the land fund exhausted, the Province of Otago, at least, will be committing political suicide if it permits itself to be absorbed in the Middle Island' and he advocated sending strong representatives to the General Assembly to uphold the provincial rights conferred by the Constitution Act. ${ }^{21}$ In his editorial rejoinder, Vogel claimed that Macandrew had adopted compromising tactics such as 'a certain smoothness and oiliness of speech, vacillation of purpose, and trimming of opinions to suit both parties' and he suggested that 'the truth is the federation of the provinces of New Zealand is one of incongruities - there is no community of interest. ${ }^{22}$ Macandrew acknowledged that the Assembly 'has got almost unlimited power to do anything not repugnant to the law of England-power, to a great extent, even to remodel the Constitution Act; temporarily to abnegate its own functions, should the interests of the colony render it expedient so to do ${ }^{, 23}$ but he suggested it was better to work within the Assembly before considering separation - a demonstration of his pragmatic approach to politics rather than the opportunism with which McLintock labels him. ${ }^{24}$

The newly-formed Southern Separation League held public meetings in February 1865 and at one Macandrew displayed his ubiquitous optimism when he was reported as 'differing from the declared policy of the Separation League of dismembering the colony, he yet looked upon it as tending to a better day, as he looked upon it as a proof that breath had been infused into the political dry bones of the Province. ${ }^{, 25} \mathrm{He}$ considered that the Province was currently destitute for several reasons including 'The Land Regulations,

${ }^{21}$ ODT, 16 January 1865.

22 Ibid., 21 January 1865.

${ }^{23}$ Ibid., 25 January 1865.

${ }^{24}$ McLintock, Otago, p. 561.

${ }^{25}$ North Otago Times, 9 March 1865. 
which have been chopped and changed and reversed till no ordinary mortal could comprehend them' as well as by the inefficient administration of the Land Office and a huge investment in roads, a dredge and the Exhibition Building.

The equitable sale of land absorbed the provinces throughout their existence, with land laws no sooner passed than further amendments were tabled. Governments could be unseated for their land policy and in April 1865 Macandrew censured the Provincial Executive for their action in remitting, without consultation, a land tax to purchasers in order to encourage land sales and return the Province to liquidity. While not rejecting the spirit of their action, he repudiated their repeal of an Act when the Council 'alone had the right to appropriate revenue, which was aimed at in the proclamation. ${ }^{26}$ The Executive resigned and Macandrew was amongst those asked to form a government-he declined and his behaviour provoked conjecture about his ambitions. ${ }^{27}$

Vogel continued to promote complete separation and in May 1865 moved in Council that it was 'in the interest of both the Northern and Middle Islands of New Zealand to be separated into distinct colonies' and suggested a meeting of provincial delegates to prepare a request for the General Assembly but his motion was lost when Macandrew recommended delay. ${ }^{28}$ On 12 May another rising politician, Donald Reid, who in the shifting tides of colonial politics was later to be Macandrew's implacable political opponent, then his ally, supported Macandrew's motion that it was 'inexpedient to raise the question of separation of the Northern and Middle Islands of New Zealand until the policy of the present General Government shall have a fair and reasonable time to develop itself. ${ }^{29}$ Its passing was a rebuff to Vogel whose waning personal popularity undermined the usefulness of his contributions. ${ }^{30}$

When Superintendent John Hyde Harris indicated in June that he would resign, local gossip suggested that 'in the event of Mr. Macandrew offering himself, he would, despite his previous laches, have a large amount of support, and run any other candidate a

\footnotetext{
${ }^{26} \mathrm{BH}, 20$ April 1865.

${ }^{27}$ NOT, 27 April 1865.

${ }^{28}$ V. and P., OPC, Session XX, 5, 10 May 1865, pp. 50, 57.

${ }^{29}$ Ibid., 12 May 1865, p. 65.

Donald Reid, 1833-1919. Farmed Salisbury on Taieri Plains 1857-1912, became extremely wealthy transporting freight to goldfields, Member OPC 1863-76, Otago Executive Council 1868 (2 days), 1869-72, 1874-76, MHR 1866-69, 1871-78, Minister of Public Works (Stafford Ministry) 1872, Minister of Crown Lands and Immigration (Atkinson Ministry-reconstituted) 1877.

${ }^{30}$ NOT, 27 April 1865: 'The Council is growing impatient of that interminable fault-finding which he adopts as a medium for his talking propensities.'
} 
hard race. ${ }^{31}$ Macandrew did not stand, choosing instead to run for the seat of Bruce in the General Assembly to endorse his view that it was important for Otago to have strong Assembly representatives who supported unfettered provincial government. During electioneering, he deplored the growth in central spending and indebtedness which was 'chiefly owing to the political apathy of the people, and the absence of public opinion on political subjects' and maintained that the General Government should have nothing to do with Land Regulations. ${ }^{32}$ The opinion of one editor, that in Macandrew 'the Electors could scarcely find any one who holds sounder or more liberal views as to the disposal of the Waste Lands ${ }^{33}$ was endorsed by his resounding win on 26 July 1865, by 207 votes to 34 for John Cargill, ${ }^{34}$ proving another editor's claim that 'strange as it may seem, the name of Mr Macandrew's friends is legion. ${ }^{35}$

Politically redeemed and carrying the aspirations of Otago, he sailed for Wellington on 5 August $1865^{36}$ to attend the fifth and last session of the Third New Zealand Parliament ${ }^{37}$ where, it was suggested, 'Otago's influence in the Assembly will be increased by the presence of a sound, far-seeing, and practical statesman, one who has the prosperity of the province thoroughly at heart, and who is able to make himself heard and felt in the Legislature of the Colony. If Mr. Macandrew committed grave errors, he had expiated them severely. ${ }^{38}$ When Macandrew and Vogel with their opposing views on separation departed together for the north, a commentator noted that 'it is not often that two such staunch antagonists are crowded within so narrow a space; and curiosity was raised as to how they would spend their time on the voyage' but by the time they returned from Wellington they were allies, their reputations enhanced by their opposition to the growing dominance of the central government. ${ }^{39}$ Premier Weld's goal of colonial selfreliance in the North Island War and his rejection of Imperial support and control meant greater cost for all New Zealand settlers. In a move guaranteed to anger Auckland and Otago, Weld's Ministry had increased its share of customs revenue and had proposed a

\footnotetext{
${ }^{31}$ Evening Post, 19 June 1865.

${ }^{32}$ ODT, 20 July 1865.

${ }^{33} \mathrm{BH}, 20$ July 1865.

${ }^{34}$ ODT, 1 August 1865.

${ }^{35}$ NOT, 27 July 1865.

${ }^{36}$ ODT, 5 August 1865.

${ }^{37}$ Scholefield, Parliamentary Record, pp. 68 \& 121: 'The Assembly sat from 26 July-30 October 1865 and was dissolved on 27 January 1866.'

${ }^{38} \mathrm{BH}, 10$ August 1865 .

${ }^{39}$ EP, 10 August 1865.
} 
stamp duty. ${ }^{40}$ By attacking the reduction in provincial income, and the new tax, Vogel bolstered his reputation for financial shrewdness but his want-of-confidence motion in the Government was narrowly lost.

In November 1865 the new Superintendent of Otago, Thomas Dick, welcomed the Council and summed up provincial dissatisfaction. ${ }^{41}$ He deplored the poor relationship existing between central and provincial governments and charged that 'on the Provincial authorities rests the onus and responsibility of advancing all the material interests of the Province, and of preserving peace and good order within its bounds, while we are disabled from promptly appropriating, as emergencies arise, the great resources that would otherwise be at our disposal.' When a Select Committee appointed to investigate Dick's complaint reported on 27 November, Macandrew's influence was obvious as he had foreshadowed the Committee's ten recommendations in an address to the electors of Port Chalmers. ${ }^{42}$ This was the first instance of Vogel and Macandrew acting in concert and on the Committee, a more moderate Vogel supported Macandrew's viewpoint and abandoned his demand for insular separation.

The Select Committee recommended the rejection of complete separation, and suggested instead 'a financial separation between the Islands or between their respective Provinces, and that the political relations between the General and Provincial Governments should be remodelled.' ${ }^{43}$ It endorsed a model of government where 'the Executive functions of the General Government be confined to matters of purely federal concern, and that the Executive functions of the Provincial Governments be largely increased' and proposed the repeal of the New Provinces Act 1858, the amalgamation of Taranaki and Auckland Provinces, the reduction of the General Government to three departments (Colonial Secretary, Treasurer, Attorney-General), the delegation of native affairs to the provinces, and the reallocation of financial liabilities for loans and the cost of government. Moss recorded his dissent to five clauses but the Report was adopted by the Council. ${ }^{44}$ Unsurprisingly, when the report was published colony-wide, some residents of the smaller provinces took umbrage at Macandrew's extreme views: one wrote that 'Mr. Macandrew...looks to the end, without troubling himself greatly about the means. Nor is

${ }^{40}$ Dalziel, p. 65.

${ }^{41}$ V. and P., OPC, Session XXI, 15 November 1865, p. 1.

${ }^{42}$ ODT, 8 November 1865 contains Macandrew's address.

${ }^{43}$ V. and P., OPC, Session XXI, 27 November 1865, Reports of Select Committees, Relations Between General and Provincial Governments, pp. 1-2. Members were George Brodie, Arthur Burns, Frederick Moss, William Reynolds, Macandrew and Vogel.

${ }^{44}$ Ibid., 8 December 1865, p. 45. 
the end he has in view of a very elevated character; it is narrow and designed for selfish and local means ${ }^{45}$ while another complained that 'the people of Taranaki are not mentioned, but we suppose they will be handed over as serfs attached to the soil. ${ }^{46}$ Otago politicians had a talent for upsetting their fellow colonists!

The Committee's Report became the basis of Otago's demands in the General Assembly, in return for supporting Stafford who desperately needed any backing he could muster following his unseating of the well-liked Weld. Stafford, the Premier who had sponsored the New Provinces Act of 1858, who had advised the Governor to dismiss Macandrew as Superintendent in 1861, Stafford the man 'who has been, so long as it suited him, the great enemy to all provincial powers' was now obligated to Macandrew and the ultra-provincialists for his political survival. ${ }^{47}$ Macandrew's status in the General Assembly grew from this point.

In June 1866, Macandrew, now the Member for Clutha, supported an unsuccessful motion to delegate more powers to the provinces but the provincialists were outflanked by Premier Stafford who reduced their share of the customs revenue. Dunedin residents were outraged and a public meeting was held on 4 September which protested against 'every measure having the effect of diminishing the proportion of the revenue at present locally appropriated. ${ }^{48}$ From this meeting an Otago Association emerged, to watch over and promote the various interests of the Province and to supplant the Middle Island Association which had been established earlier along more general lines to awaken the public to the threat to Middle Island interests from General Assembly legislation. ${ }^{49}$ On their return from Wellington in October, Macandrew and Vogel's stocks were high and they won plaudits for their pro-provincial stance. In Dunedin they were greeted by a cheering mob and paraded through the town behind a band while the six Otago members who had supported Stafford-Bradshaw, Arthur Burns, John Cargill, Haughton, O’Neill, Paterson and Richardson, were jeered with equal vehemence. Their effigies were paraded through the town then thrown into the sea. ${ }^{50}$

\footnotetext{
${ }^{45} N E, 2$ December 1865.

${ }^{46}$ Taranaki Herald, 9 December 1865.

${ }^{47}$ Canterbury Press, 10 March 1866.

48 ODT, 5 September 1866.

49 Ibid., 19 October 1866. The Otago Association's aim was 'obtaining the largest possible amount of selfgovernment.'

${ }^{50}$ West Coast Times, 22 October 1866.
} 
On opening the Council in November 1866 Dick noted that 'Acts have been passed which interfere with the internal Government of the Provinces, and should therefore have been left for the consideration of Provincial Councils. ${ }^{51}$ Some Councillors took umbrage at this but their attempt to amend the Address-in-Reply was lost. ${ }^{52}$ This precipitated the resignation of the Executive and led to Vogel's appointment as Provincial Treasurer, his first appointment as a member of a Ministry, and his first to a position of responsibility where he could no longer be an unconstrained critic. ${ }^{53}$ Firm leadership was expected from Vogel's Executive and one scribe mordantly suggested that 'they will not regard any question as a Ministerial one, short of a direct want of confidence motion. They will swallow as many leeks as there may be occasion for, but sacrifice power to high principle-never. ${ }^{54}$

Vogel's new attitude to the provinces was demonstrated when his Executive supported only the financial separation of the islands and it was Macandrew who wanted to go further. Macandrew declared that on the 'battle field' between the General and Provincial Governments, 'if there was to be peace in the Colony, one or the other must give way. ${ }^{55}$ Despite assertions that the days of provincialism were numbered, he held that the provinces 'were only on the threshold of their existence' and their mission was 'colonising and settling the country.' Meanwhile, in Otago their work had just begun and 'until every part of the Province was as accessible as the Taieri Plain-until all the land had been sold - until all the rivers had been bridged - until the country was intersected by railways - until the population could be counted by thousands, where there were now hundreds - until then, the work of the Province would not be ended; and then the Provincial system would die a natural death.'

Macandrew and Vogel now parted company over provincial powers. Vogel's political shrewdness was demonstrated in the dying days of the Session by an episode which also demonstrated how thoroughly Macandrew's firm views could polarise his colleagues: 'He has strong views on every subject, and his way of stating them is, at least, as strong as the views he holds ' was the view of one commentator who continued 'There is something very trenchant and incisive about Mr. Macandrew's way of stating his views, which is refreshing by contrast with the verbiage which usually marks the speeches of

\footnotetext{
${ }^{51}$ V. and P., OPC, Session XXII, 6 November 1866, Superintendent's Address, p. 2.

${ }^{52}$ Ibid., 8 November 1866, p. 7. Macandrew and Vogel were both absent for this vote.

${ }^{53} \mathrm{Ibid}$., Session XXII, 21 November 1866, p. 11.

${ }^{54}$ NOT, 27 November 1866.

${ }^{55}$ ODT, 30 November 1866.
} 
public men to their constituents. ${ }^{56}$ The appointment of an Emigration Agent in Great Britain was proposed and following 'a storm such as has not been known before in the byno-means peaceful annals of the Provincial Councils of Otago', Macandrew's name emerged from fifteen contenders. ${ }^{57}$ At this 'a vast amount of vituperation was heaped on the devoted head of Mr. Macandrew' and Speaker Richardson, who disliked him intensely, resigned rather than put the question so that the appointment lapsed. ${ }^{58}$ Reports then had it that Vogel did not intend to make an appointment at all: the Bill was just a display of activity to suggest his Ministry was energetic and worth supporting in the forthcoming election. $^{59}$

\section{SUPERINTENDENT 1867-1871}

Gold transformed Otago from poor and conservative to rich and radical when an influx of thousands of miners and the impact of unconstrained wealth stimulated a desire for development and expansion. Superintendent Dick, devout and honest, was also cautious, unimaginative and dull, and not the leader a booming economy required. ${ }^{60}$ Macandrew had been elected to the Council by voters who wanted to benefit from the gold rush and by 1867, firmly re-established in both legislatures and determined to protect Otago's autonomy, he was ready to challenge the sitting Superintendent. Despite his denial, the Superintendent's salary of $£ 900$ per annum would have greatly assisted his financial situation. ${ }^{61}$

His challenge to Dick was first hinted by the Bruce Herald. ${ }^{62}$ It was made official on 31 January 1867 when Macandrew announced modestly that 'having received numerous signed requisitions...I have, although reluctantly and at the last moment, felt it my duty to comply. ${ }^{63}$ Speaking bluntly, he acknowledged that he was motivated by righteousness as well as public service: 'Gentlemen, it is useless mincing the matter. I feel that a great political wrong was done to me in 1860 , and that the province has been greatly the loser.' But his modesty was disingenuous when he claimed that 'there is not a public man in New Zealand, who, personally or relatively, has derived less pecuniary benefit from the public than myself...it is not the emoluments of office by which I am influenced.'

\footnotetext{
${ }^{56} N E, 11$ December 1866.

${ }^{57}$ Nelson Evening Mail, 5 January 1867.

${ }^{58}$ GRA, 8 January 1867.

${ }^{59}$ V. and P., OPC, Session XXII, 20 December 1866, p. 44; BH, 27 December 1866.

${ }^{60}$ McLintock, Otago, p. 497.

${ }^{61}$ V. and P., OPC, Session XXII, 1866, Appendix, Council Paper $N^{o}$ V, Proposed Expenditure, p. 9.

${ }^{62} \mathrm{BH}, 17$ January 1867.

${ }^{63}$ Ibid., 31 January 1867.
} 
He considered that his political views were so well known that 'I may state that my maxim is diffusion as against centralisation, either Colonial or Provincial.' His nomination on 4 February for the position from which he had been officially dismissed six years earlier flabbergasted his opponents and elated his supporters - mud soon began to fly.

The 1867 contest for the Superintendency was the last in which Macandrew's misdemeanours were the focus of the campaign. In his successful runs for Superintendent in the 1871 and 1873 elections, he was a well-established politician, with a reputation for success as well as being a leading defender of the provinces so that his dubious past was glossed over. Accordingly, the published accounts of February 1867 provide a last opportunity to examine the unvarnished opinions of his critics and followers before the record was distorted in later years by the nostalgia generated by his heroic status. The accounts also throw an interesting light on the relationship between Macandrew and Vogel, erstwhile collaborators in both seats of government.

Vogel, as editor of the Otago Daily Times, led the critics. ${ }^{64}$ Although sharing many political positions, Vogel took a dim view of Macandrew's moral standards and attacked him fiercely during the campaign. His first move was to print in full Auditor-General Dr. Knight's 1861 Report on his enquiry into Macandrew's alleged defalcations. ${ }^{65}$ Macandrew's continuing sin, Vogel contended, was 'that he was not proof against temptation, and that, succumbing to it, he went from bad to worse, magnifying his wrong doings by the defence he set up of them' and that 'his candidature is opposed upon the ground, that he has not cleared up the circumstances which led to his former expulsion, and that in the absence of such exculpation, it is impossible to concede to him the position of the first personage in the Province. ${ }^{66}$ Macandrew's response strained belief. At a crowded meeting, in an eloquent speech, he claimed he had not seen the Auditor-General's Report until it was published the previous day, and his dismissal and disgrace were not the consequences of the Report but came from his personal financial misfortune. On the campaign platform he adapted facts to appeal to the widest audience, a tendency tolerated by his supporters who accepted that he was the victim in 1861 of a 'diabolical political conspiracy.' But, Macandrew asked 'what benefit is to be derived from stirring up...the

\footnotetext{
${ }^{64}$ Dalziel, p. 71. Cutten had resigned as a proprietor in 1866.

${ }^{65}$ The Report of the Commissioner Appointed to Examine the Public Accounts of the Province of Otago, originally published in the Otago Provincial Gazette, 7 June 1861, p. 199 and reprinted in the ODT, 1, 2, 5, 6, 7, 8 February 1867.

${ }^{66}$ ODT, 1 February 1867.
} 
mud creeks to their lowest depths? ${ }^{67}$ He made many references to his achievements, emphasised his experience as Superintendent and made grandiose promises. Macandrew the showman even produced tears, excusing himself with 'Pardon me, but the fact is that these matters bring reminiscences to my mind, somewhat calculated to overcome one. ${ }^{68}$

Vogel continued to attack Macandrew's morals for the rest of the campaign, repeatedly recalling the events of $1860-61 .{ }^{69}$ Later, he reminded readers that Macandrew had 'left the Home country deeply in debt' and in New Zealand 'he sought to purchase political capital with the money of his creditors.' He accused Macandrew of undeservedly taking credit for agricultural and immigration progress and when a member of the Waste Lands Board, he "jobbed and trafficked in runs daily. ${ }^{70}$ The Otago Witness took a different tack and appealed to its readers' higher principles - it was impossible to forget the past and what would the world think of New Zealand if Macandrew were to be elected. $^{71}$

The Bruce Herald, owned by Joseph Mackey, was an indefatigable supporter. The editor admitted that after reading the Report that 'we do not maintain that Macandrew was guiltless of error or free from irregularities, but we are of opinion that they cannot be deemed so heinous, as to be incapable of explanation or of forgiveness...he is so well qualified by his energy, comprehensive mind, and consummate tact, to raise this Province from its present humiliating position. ${ }^{, 72}$ The Herald shared Macandrew's belief that 'The Middle Island possesses all the elements of a great colony, if we could only "cut the painter" at Cook's Strait.' When a city merchant labelled Macandrew's supporters 'a "rabble" the Herald responded "never were the mechanics or the laboring class so stigmatised since the passing of the Reform Bill in the British Parliament...Working men of Otago, Macandrew is your friend, and you know it.' Macandrew's ability to relate to a wide range of people gave him a close bond with many voters such that 'many old settlers, who have now their own freehold farm, or their business as storekeepers, can testify to the fact if they will, that their good fortune is attributable to a start, in the land of their adoption, by Mr. James Macandrew' and they returned his affection. ${ }^{73}$ This was demonstrated at a rally in Green Island where the settlers insisted on pulling Macandrew's

\footnotetext{
${ }^{67} \mathrm{BH}, 7$ February 1867.

${ }^{68}$ ODT, 4 February 1867.

${ }^{69}$ Ibid., 14 February 1867.

${ }^{70}$ Ibid., 19 February 1867.

${ }^{71} \mathrm{OW}, 2$ February 1867.

${ }^{72}$ BH, 7 February 1867.

${ }^{73}$ Ibid., 14 February 1867.
} 
carriage by hand to the meeting place despite his strong objections and 'for the first time in Otago, the populace thus exhibited their appreciation of a political leader. ${ }^{, 74}$ Macandrew, by now, had become the complete populist.

The same enthusiasm was evident when Macandrew spoke to constituents throughout the province at up to three meetings a day, and when he addressed a crowd of about 2,500 at Dunedin's North Recreation Ground on the evening before polling day. ${ }^{75}$ Copies of Vogel's Otago Daily Times were burnt with mock ceremony before Macandrew delivered a rousing speech of dubious veracity in which he defended his response to the 1861 defalcation charges, claiming of the Clutha Coal Plant debt 'that irregularity was made good by myself, inasmuch as I have paid it personally, years ago. ${ }^{, 76}$ Emphasising the rhetoric of development, he accused his opponents of lethargy, that 'there is a want of energy and of business tact about the (Vogel) Executive of this Province.' He vowed to be an active Superintendent 'I will be no puppet in the hands of any men' and he promised to build railways to all corners of the province. He declared that "we have two Governments performing the work which one might effect. My policy would be to converge the powers, and to dispense with the one Government or the other...to carry on the Government for one half of what it now costs' and once more he promised to 'devote all the influence of my office to accomplish separation between the Northern and the Middle islands.' Then he repeated the allegation that he was the victim of a political conspiracy 'as diabolical as it was unscrupulous' and named Thomas Gillies, William Cutten and Major Richardson as the conspirators. Finally he claimed to have made no profit from his public service.

Macandrew's enthusiastic stump talk was what the crowd wanted to hear and his victory was confirmed on 20 February 1867 with $62 \%$ of the votes. He won all the booths from the Waitaki to the Tokomairiro, but surprisingly, and a portent of future strife, he did not win in Balclutha, the hub of his General Assembly Clutha Seat, or in the goldfields except the rural centres of Roxburgh, Alexandra and Cromwell. ${ }^{77}$ One commentator judged Macandrew's support came from 'nearly all of the trading classes and a large proportion of the artisans of Dunedin' and considered that 'this election must be accepted as emphatically a revolt. ${ }^{, 78}$ But despite his jubilant welcome by the working class of Otago,

\footnotetext{
${ }^{74}$ Ibid., 21 February 1867.

${ }^{75}$ Ibid., 4 February 1867, 'Election Meetings'.

${ }^{76}$ Ibid., 20 February 1867.

${ }^{77}$ Ibid., 28 February 1867. Macandrew won 2,260 votes, Thomas Dick 1,392 while the third contender, J.G.S Grant, received 2 votes.

${ }^{78}$ NOT, 26 February 1867.
} 
his victory triggered a storm of protest across New Zealand and prompted such unprecedented responses that, ironically, the abolition of the provinces may have been hastened. He was also faced with forging a working relationship with Vogel, the leader of his Executive Council.

Reaction to Macandrew's re-election as Superintendent of Otago was swift and disparaging. The Timaru Herald considered optimistically that 'in electing a man of Mr. Macandrew's character, Otago has signified she no longer desires provincial independence, for at that she has now aimed a death-blow, and sooner or later provincialism will be an institution of the past. Although Mr. Macandrew being again in office is not only a disgrace to Otago, but also to the whole of New Zealand, still, being a means to an endthe downfall of provincialism - we cannot say we regret his election. ${ }^{79}$ The Wellington Independent deemed 'that the Otago majority have proved themselves either not very particular, or not very intelligent' and worried about the election's impact on the reputations of the province and of New Zealand and on Home money, ${ }^{80}$ while a West Coast newspaper, eager for self-government and sensitive to process, claimed 'this result is the more extraordinary, considering the extreme efforts made by Mr. Dick's party. Not a stone was left unturned to bring Mr. Macandrew into public contempt' and raised the possibility that the Governor should veto Macandrew's appointment. ${ }^{81}$ A populist Auckland newspaper, addressing a large, diverse and class conscious province, suggested that 'his election is a sign of the times. He has trampled - or rather the bone and sinew of the province have trampled, through him-on the squatting and moneyed interest, aided and abetted by the Provincial Executive and the leading newspaper. ${ }^{82}$ The Taranaki Herald, whose readers were suffering downturn and war, saw wilfulness in his election: 'we deplore the fact as a dishonor to the whole Middle Island, and as casting shame on popular institutions...the people of Otago may be assured that their miserable infatuation will furnish an irresistible weapon to the centralists... have brought provincial institutions throughout the colony into disrepute. ${ }^{83}$

Undaunted by criticism, Macandrew assumed office on 27 February and wrote immediately to Premier Stafford requesting delegation of the Governor's powers under

\footnotetext{
${ }^{79}$ Timaru Herald, 27 February 1867.

${ }^{80}$ WI, 28 February 1867.

${ }^{81}$ GRA, 2 March 1867.

${ }^{82}$ Daily Southern Cross, 14 March 1867.

${ }^{83}$ Taranaki Herald, 16 March 1867.
} 
The Gold Fields Act, 1866, and also under The Diseased Cattle Acts, $1861 \& 1865 .{ }^{84}$ Macandrew's election promise to fold two governments into one soon evaporated when the needs of state arose, despite his Assembly recommendation in July 1866 that Wellington retain complete control of the goldfields. Stafford, perturbed by Macandrew's win, stalled because he knew that his recommendation to veto the election result would make Macandrew an Otago martyr, so the Premier looked for a legal reason for dismissal. That same day he despatched the Auditor-General Dr Knight to Dunedin to investigate the refractory item of $£ 1012$ 14s 5 d labelled 'Defalcations by James Macandrew, Esquire' which had appeared in the Provincial Appropriation Ordinance, 1861-2. Knight's investigation now met opposition from Provincial Treasurer Vogel who was offended by a breach of official etiquette - Knight had neglected to inform him that he was inspecting the Otago Treasury books - and further resistance from Macandrew, who declared that unless the Provincial Council wanted to reopen its 1860 enquiry, he would not allow the General Government to continue its investigation. ${ }^{85}$ Knight closed his enquiry immediately but reported to Stafford that 'some party has secured a pecuniary advantage of $£ 101214 \mathrm{~s} 5 \mathrm{~d}$ at the expense of the Provincial Treasury. ${ }^{, 86}$ This was sufficient for Stafford, a month later, to inform Macandrew that the delegation of Governor's powers to the previous Superintendent to manage the goldfields had lapsed and that James Bradshaw, the General Assembly Member for the Seat of Goldfields Towns, had been appointed Government Agent for the Gold Fields. ${ }^{87}$

The perception of a deliberate insult to the Province united the people of Otago, and drew Macandrew and Vogel back into partnership: Vogel was the leader of Macandrew's Executive Council and both considered provincial independence was at risk. They were concerned that public works, policing and other services would no longer be provided on the goldfields and were concerned about the loss of income for the provincial coffers when the province was unable to issue grazing licences in the goldfields. Other goldfield regions were appalled. 'It is impossible to exaggerate the evil and confusion that

${ }^{84}$ AJHR, 1867, D-1, Papers Relative to the Case of Mr. Macandrew, letter No. 15, p. 38. This Appendix is a full and valuable record of Macandrew's behaviour when he was Superintendent in 1860 which was resurrected on his return to the House in 1867. The papers contain the Otago Provincial Council's 1860 Select Committee Report and evidence, Dr. Knight's 1861 Report and evidence, subsequent letters regarding his Report, and further correspondence concerning the delegated powers, between the Premier's office and Macandrew, written between February and June 1867; Stafford's instructions to Knight are in letter No. 17, 8 March 1867, p. 39; Dr Knight's Report on his 1867 review is in letter No. 19, Enclosure 2, 18 March 1867, p. 41.

${ }^{85}$ Ibid., letter No. 19, Sub-Enclosure 2 to Enclosure 2,15 March 1867, p. 42.

${ }^{86}$ Ibid., letter No. 19, Enclosure 2, 18 March 1867, p. 42.

${ }^{87}$ Ibid., letter No. 20, 16 April 1867, p. 43. 
will spring out of this usurpation of authority' raged a Westland newspaper and foretold anger, excitement and the use of language 'savouring a good deal of revolution.' There was talk of seizing the Otago Customs House and mobilising the militia 'for the purpose of resisting the chief authority of the colony! ${ }^{88}$ Even the Otago Daily Times changed sides, to the confusion of many people. ${ }^{89}$ Voters met to disapprove of the Premier's action and support Macandrew while a petition requesting separation of the Governments of the two islands signed by over 2,000 citizens was presented to Governor Grey when he visited Otago in March. ${ }^{90}$ Grey counted Macandrew as one of the intransigent Scottish Presbyterian settlers with whom he had clashed in the past and because of the irresolution regarding the election, did not meet with him. ${ }^{91}$ Meanwhile, the Council Executive blocked Bradshaw's access to public buildings and records, and goldfields officers were instructed to decline Bradshaw's instructions. ${ }^{92}$

When the Otago Provincial Council opened in May 1867, Macandrew asserted that it was impossible for the present state of affairs to continue - the provinces must fight back. 'It is said that the system has been extravagant and expensive. If so, it has been our own fault, and the remedy is in our own hands' he stated, then influenced no doubt by news of the impending union of the Province of Canada with the Colonies of New Brunswick and Nova Scotia on 1 July 1867, he suggested that New Zealand become a federation. ${ }^{93} \mathrm{He}$ claimed that 'the spirit and intention of the Constitution Act evidently is that the General Government should be federal in its action, and the circumstances of the Colony pointed to this as the advisable form of government, otherwise what necessity was there for creating distinct machinery for provincial legislation?' He warned that Separation could only be approved by Great Britain's Parliament and in the meantime Otago had to fight for its rights in the General Assembly. The Council supported him and Vogel resurrected his Resolutions of the preceding November which were incorporated into a Separation Petition to Queen Victoria, asking her to translate the Middle Island into a separate Colony and to establish a Federal Union of the two Colonies 'such as has taken place in British North

\footnotetext{
${ }^{88}$ GRA, 30 April 1867. Macandrew wrote 24 April 1867 to Major-General Chute, 1817-86, GOC Imperial Forces, and telegraphed Governor Grey 27 April 1867, suggesting a revolt in Otago was possible.

${ }^{89}$ NOT, 23 April 1867.

${ }^{90}$ Nelson Examiner, 14 May 1867. Port Chalmers residents resolved to form 'the Port Chalmers Vigilance Association for the preservation of their political liberties.'

${ }^{91}$ Despatch: Governor George Grey/Edward Cardwell, Secretary of State for the Colonies, 30 May 1865, ANZ, Wellington, G 25 10/ 77.

${ }^{92}$ ODT, 20 March 1867.

${ }^{93}$ V. and P., OPC, Session XXIII, 1 May 1867, Superintendent's Address, p. 4.
} 
America. ${ }^{94}$ Macandrew, firmly ensconced with Vogel as his "Prime Minister" and with his brother-in-law now Provincial Speaker, demonstrated the new order by presenting the Council with a Gold Fields Provincial Management Bill which made provision for a plebiscite for 1 June, to decide if the Superintendent and his Executive Council should continue to manage the Otago Gold Fields. ${ }^{95}$ Unsurprisingly, the plebiscite was carried by 8,304 votes to 178 but Stafford refused to back down. ${ }^{96}$

Colonial newspapers opined that the Premier could have engineered Macandrew's dismissal by gubernatorial veto immediately the election result was promulgated, on the grounds of Macandrew's previous removal from that office, but by leaving him in office and cancelling the Governor's delegations it was felt that the Gold Fields imbroglio 'smacks of poltroonery and dishonesty. 97 Thus encouraged and united in their view on the necessity for separation, Macandrew and Vogel, with Reynolds, sailed to Wellington to confront Stafford in the General Assembly which sat from 9 July 1867. There, a compromise was reached when Stafford's original decision was rejected and the Governor's power of delegation was made over to the Provincial Executive Councils instead of the Superintendents. ${ }^{98}$ In Otago eyes, Macandrew had won another round.

On his return, ever self-assured, Macandrew reported back to his electorate in November that there had been an enormous amount of talk during the Assembly session and 'a perfect crop of ill-natured acts had been passed' yet taxation and expenditure had not been reduced and the financial system was not reformed. ${ }^{99} \mathrm{He}$ denounced the annual gathering of the General Assembly as wasteful and unnecessary. He said New Zealand had five distinct entities-Auckland, Canterbury, Wellington, Nelson, and Otago — so 'give to each of the five full powers of self-government, and each would work out its own destiny. Let there be, in addition, a Federal Council, meeting every two or three years....The General Assembly was a body not adapted to the circumstances of the country. We were just trying to mould together a number of incoherent materials, before they were ripe for fusion; and to do that was an impossibility. ${ }^{100}$ With that, the Superintendent, unperturbed

\footnotetext{
${ }^{94}$ Ibid., Reports of Select Committees, XVI-Separation Petition, 28 May 1867, p. 9. 7,325 people signed this petition; Morrell, The Provincial System, p. 182, fn. 1. The Secretary of State refused to advise the Queen to comply with the petition.

${ }^{95}$ Schedule and Synopsis of the Ordinances passed by the Provincial Council of Otago during Sessions I, 1853-4, to XXVII, 1870 Inclusive, Dunedin, 1871, p. 18.

${ }^{96}$ McLintock, Otago, p. 572, fn. 8.

${ }^{97}$ WI, 16 May 1867.

${ }^{98}$ NZPD, Vol. 1, 17 July 1867, p. 112.

${ }^{99}$ WI, 2 November 1867.

${ }^{100}$ WCT, 5 November 1867.
} 
by his Assembly confrontations or by family matters, completed his turbulent year by sailing to Fiordland on the paddle steamer Geelong where he investigated the mineral deposits of Preservation Inlet, authorised the naming of the Macandrew Range above Cascade Cove in Dusky Sound, prospected at Milford Sound and Martins Bay, helped release rabbits at both sites, then returned to Dunedin via Bluff. ${ }^{101}$ If in Wellington he was beset by enemies, in Otago he was supreme.

The 1868 Otago Provincial Council began on a harmonious note for the last time in its existence. Macandrew put 'the question in which we are most deeply interested at present... what is to be the future form of government in New Zealand? ${ }^{102}$ He saw 'the true meaning of Centralism — one purse for the Colony' but cautiously, he opposed rushing into an organic change. He regretted that Otago was continually acting on the defensive in relation to the rest of the colony because 'I am persuaded that nothing is more prejudicial to the real interests of this Colony than a meddling General Government.' The only solution, as he saw it, was for each province 'to provide for its own peace, order and good government, out of its own resources, as best it may.' Members concurred which was not a difficult choice given that Otago was the only province that was financially secure. However, as recession bit even there, they became preoccupied with retrenchment, land sales and settlement, and support for Macandrew's grand projects faded accordingly.

Land sales continued to occupy much of Macandrew's energy and Council harmony dissolved when a faction led by Donald Reid demanded that new Hundreds be gazetted to encourage ever closer settlement. These, Macandrew and Vogel opposed, as they wished to maintain the Council's income from the sizeable rents generated by pastoral leases. ${ }^{103}$ Macandrew, Vogel and Reid had entered the Provincial Council together in 1863 and initially shared the same political views - a commitment to provincialism and easy access to land for deserving settlers by the use of deferred payment. Reid's struggle to become established in New Zealand made him 'for all his days the friend of the small, and often struggling, agriculturist' but following his early disputes with Macandrew over land sales, they were to become allies in the anti-abolition battle. ${ }^{104}$ But now Reid's demands split the Council and he ousted Vogel to become Leader of the Executive for two days

${ }^{101}$ ST, 18 December 1867. His father-in-law had died as the result of a house fire at Colinswood on 1 January 1867 and his $10^{\text {th }}$ child ( $8^{\text {th }}$ surviving), Mabel, was born on 15 December 1867 while he was in Fiordland.

${ }^{102}$ V. and P., OPC, Session XXIV, 8 April 1868, Superintendent's Address, p. 3.

${ }^{103} \mathrm{BH}, 10$ June 1868.

${ }^{104}$ McLintock, Otago, p. 489. 
before Vogel resumed the leadership but Council was deadlocked. ${ }^{105}$ Macandrew declined to endorse Council's request for a dissolution and new elections. Members did not want to replace their Superintendent, yet under the Constitution Act elections for one required an election for the other. His response was to suggest Council request the General Assembly to amend the Constitution Act to permit a Superintendent to dissolve a Council on a majority request, an adroit move on his part to make the Councils more effective.

Unfortunately, the suggested amendment served to remind the Colony yet again of the continuing complexity of running two tiers of government and a Wellington editor wrote, ominously, that 'the numerous expressions of divers communities in all parts of the country in favor of local government will not fail to be made capital of by the Ministry., ${ }^{106}$ Macandrew had also broken his election promise to cut Council costs and to run it more efficiently: dismay greeted the Superintendent's large salary increase and rather than the sessions being reduced, they lengthened. ${ }^{107}$ In his prorogation speech, Macandrew lamented the Council's disunity, suggested that Councillors had alienated the people and piously censured them with 'Gentlemen, there can be no question but 'an enemy hath done this." 108 The increasingly fractious Council would never reproduce this Session's early harmony and commitment to the provincial model. To cap off a dismal session, Vogel and Macandrew ended the session with a disagreement over the merits of investment in railways versus roads: Vogel had suffered a business reverse, was becoming disenchanted with Otago, and their alliance was disintegrating, but it would be seven years before they became absolute parliamentary adversaries. ${ }^{109}$

Otago's wealth was underscored when Macandrew opened the substantial Balclutha Bridge over the Molyneux River in October 1868, having demonstrated his independence by departing Wellington a month before Parliament rose. ${ }^{110}$ Otago was fortunate to be generously endowed with natural resources, but it is difficult to

${ }^{105}$ Scholefield, Parliamentary Record, p. 218. Reid was Provincial Secretary from 27-29 May 1868, from 6 May 1869 until dismissed by Macandrew on 19 November 1872 (or 25 September 1872 according to the $O D T$ ), and from 6 May 1874 until 31 October 1876.

${ }^{106} \mathrm{EP}, 20$ June 1868.

${ }^{107}$ V. and P., OPC, Session XXIV, Appendix, Statement of Expenditure, p. 3. Macandrew's salary increased from $£ 900$ to $£ 1,200$ and the salaries of the Provincial Treasurer and the Secretary of Land and Works increased from $£ 600$ to $£ 800$. The Council sat for 26 days in 1867 , an increase on the median session length (19 sitting days), but in 1868, it sat for 45 days, the second longest session in its history and subsequent sessions were also longer than the median.

${ }^{108}$ Ibid., 11 June 1868, Superintendent's Address, p. 134.

${ }^{109}$ McLintock, Otago, p. 578. Vogel was dismissed as editor of the ODT in April 1868 and established a new Dunedin newspaper which promoted provincial separation and federal government-The New Zealand Sun, was launched on 16 November 1868 and folded after three months.

${ }^{110}$ WI, 19 September 1868; Tuapeka Times, 10 October 1868. 
comprehend Macandrew's indifference to the plight of the other provinces and the resentment that Otago's affluence and his stubborn commitment to the existing model created. Otago was about to launch a huge building programme - a dry dock at Port Chalmers, a dock at Oamaru, a bridge over the Waitaki River, a railway from Port Chalmers to Dunedin, railways to north and south, more harbour and bridge works, a girls' high school, a university with a one hundred thousand acres endowment-while discussions on reunion with Southland were underway, to form an even bigger province. ${ }^{111}$ Envious settlers elsewhere who begrudged Otago's prosperity were increasingly prepared to support major change to the Constitution Act, and Macandrew's bombast must have infuriated them.

The rift between Superintendent and Councillors was widening and they heard Macandrew's usual lament about central government's policies when he opened the Council in 1869: he noted gloomily that where previously the provinces could raise loans these were now forbidden. Development was halted while taxes were to be spent on maintaining a standing army in the North Island and he expected a public rebellion soon. ${ }^{12}$ He told them he had omitted to request their change to the Constitution Act seeking authority to dissolve Council without re-electing the Superintendent and he declined to call a new election which added to Council's existing dissatisfaction with both Macandrew and Vogel. ${ }^{113}$ Council agitation increased when the Session commenced without an Executive Council because several members had resigned without notice so no responsible government was in place. Vogel was criticised for his poor management and his expedient but dubious technique for funding the proposed Southern Trunk Railway by creating a private company. ${ }^{114}$ When he was censured for depressing land prices by releasing too much land for sale, he had his excuse to resign. He turned his back on Otago and departed for Auckland in May 1869 to edit the Daily Southern Cross and to continue his political career in the north. After Vogel's relocation, and his appointment as Colonial Treasurer in June, he rapidly lost sympathy with Otago's selfish grievances. His partnership with Macandrew was crumbling and by 1873, on his election as Premier, Vogel had determined that the greater good of the country came before the prolongation of provincial privileges.

\footnotetext{
${ }^{111}$ V. and P., OPC, Session XXV, 22 April 1869, Superintendent's Address, pp. 1-3. The endowment was established in May 1869 by the University Endowment Act 1868 and the university was established by the University of Otago Ordinance 1869.

112 Ibid.

${ }^{113}$ V. and P., OPC, Session XXV, 22 April 1869, Superintendent's Message No. 1, p. 4.

${ }^{114}$ ODT, 26 April 1869.
} 
The issue of land use continued to divide the Council and wider issues were ignored: Macandrew omitted any reference to the central government in his final address. ${ }^{115}$ Council convened again in December 1869 with a full agenda of local matters: they ratified the reunion of Otago and Southland, endorsed the construction of the Port Chalmers to Dunedin Railway, and agreed to build the Southern Trunk Railway. They agreed to gazette new Hundreds and release land at Martin's Bay and Preservation Inlet for settlement and further immigration. Macandrew, without Vogel's support, and considered pro-squatter by his Clutha farmer constituents who were demanding his resignation, was attacked for his role in the passing of The Otago Hundreds Regulation Act 1869 with its high compensation rates for lessees, and for his application for an earlier $£ 50,000$ loan, both seen as primarily benefiting the pastoralists. ${ }^{116}$ Council was querulous, Macandrew's authority was challenged and his concluding remarks, wherein he regretted Council's factionalism, were mildly hypocritical in the light of his usual party-politicking in the General Assembly: 'To me, it is a matter of deepest regret that there does not appear to be this unity of action among us...Gentlemen, let each and all of us strive to be influenced less by party spirit, and more by enlightened patriotism.' ${ }^{117}$ Despite the continuing deadlock, he would not dissolve the Council.

But the noose of centralism was slowly tightening and a General Assembly motion to abolish the provinces provoked Council defensiveness and a shift of stance. ${ }^{118}$ Councillors responded with their own motion: 'that it is expedient that steps should be taken with a view to uniting the Province of Otago with the Province of Canterbury. ${ }^{119}$ Later that year, following Vogel's extraordinary Financial Statement, the Otago Councillors reiterated their view and asked the Superintendent to request a union of Otago and Canterbury, to be decided by three members of each Council and ratified by all members. ${ }^{120}$ The prickly Council next demonstrated its independence and shocked even arch-separationist Macandrew by its refusal to accept a loan for public works from the General Assembly under the just-passed Immigration and Public Works Act 1870 unless it was 'modified is such a way as will leave the Middle Island free to deal with its own

\footnotetext{
${ }^{115}$ V. and P., OPC, Session XXV, 3 June 1869, Superintendent's Address, p. 84.

${ }^{116} \mathrm{BH}, 15$ September 1869.

${ }^{117}$ V. and P., OPC, Session XXVI, 23 December 1869, Superintendent's Address, pp. 32-3.

${ }^{118}$ Colonist, 16 July 1869. On 12 July 1869, Edward Stevens, Member for Selwyn had moved: '(3) That Provincial Government should cease to exist, and a system of local government be established throughout the Colony.'

${ }^{119}$ V. and P., OPC, Session XXVII, 18 May 1870, p. 42.

${ }^{120}$ Ibid., Session XXVIII, 21 November 1870, p. 12.
} 
finances for the promotion of Public Works and Immigration. ${ }^{121}$ Councillors claimed that the only way to achieve 'such a desirable result is by financial separation of the two Islands.' Macandrew, closely attuned to the realpolitik, knew the provinces' powers were irretrievably trimmed and responded that 'if Provincial Government is to stand in the way of peopling the province, developing its mineral resources and intersecting it with Railways, then perish Provincial Government!' which probably cost him his Clutha seat three months later. ${ }^{122}$ Relationships between the Superintendent and the Council worsened and just two weeks later the Council formally sought 'Insular and Financial Separation between the North and Middle Islands.' ${ }^{123}$ Macandrew and his Council were at loggerheads and he was able to maintain their support only by proposing increasingly radical solutions to avoid abolition.

The General Assembly and the Otago Provincial Council were occupied for the next six years by 'Questions involving great Constitutional changes' as economic conditions fluctuated, as political views evolved and as fledgling parties in both Houses confirmed their approaches to governing the country. Although there had been growing dissatisfaction with the provincial system from its start, Stafford, Premier from 1865 to 1869, had been faced by a determined and well-organised provincialist opposition. Without firm commitment from his supporters he had been able to modify the Constitution Act but without making the major changes he wanted. Transformation emerged when the pragmatic Vogel became responsible for the Colony's sagging economy in 1869, but it took dire financial straits to hasten major change. In this period, as Colonial Treasurer, then Premier from April 1873, Vogel drove the political agenda and shaped the government of the Colony while Macandrew and his fractious Otago supporters were forced into a defensive stance. Finally, in 1875, abandoned by their allies, the provincialists were outvoted and after twenty-four years of life, the beloved Otago province ceased to exist.

\section{SUPERINTENDENT 1871-1876}

The political landscape had altered considerably during Macandrew's first fouryear term. Southland and Otago had reunited on 5 October 1870, the war in the north was winding down and settlement and immigration had received a mighty boost from Vogel's

${ }^{121}$ Ibid., 24 November 1870, p. 24.

${ }^{122}$ Ibid., 25 November 1870, Superintendent's Message No. 3, p. 26.

${ }^{123}$ Ibid., 5 December 1870, p. 48. 
public works programme. Despite these positive events, Macandrew had been forced into a vigorous defence of his stance on the provinces when the election campaigns for the Superintendency, and for Council and Assembly, began in the Spring of 1870.

Agitation for his resignation in Clutha first surfaced in 1869, generated by his seeming bias towards the pastoralists and by his support of the Fox Ministry which succeeded Stafford and held power for three years until 1872. Macandrew's critics claimed he had thwarted working men from acquiring their own land while he was also attacked for undermining provincial authority by supporting Vogel's public works programme which was intended to bring investment and settlers to the country. Nor was Macandrew helped when Vogel visited Dunedin in 1870 to explain his policy and to support Macandrew's campaign. A hostile audience ensured that the rally was 'unequalled by any scene which had before occurred at a public meeting in New Zealand' and Vogel rebuked them. They were not helping, he said, 'the cause of provincialism by endeavouring sullenly to stand in opposition to the determination of the Assembly, that there are certain works - the work of settlement - in which it should aid the provinces, the provinces not being strong enough to carry out the work themselves. ${ }^{124}$ Many Otago residents thought they were!

It was ironic that Macandrew, who once supported complete separation but was now a moderate provincialist, had been out-flanked by his ultra-separationist critics who dominated the Provincial Council. In a stump speech, he explained his volte face, claiming that 'there was no disguising the fact that Provincialism was on its last legs, and although he had always been an ultra-provincialist, he did not see how to avert the impending change which must, in the case of Otago, come about within a few years...He admitted that it was rather odd for him, as an ultra-provincialist, to go in for the centralism involved in the Public Works Scheme; but much as he was attached to the provincial system, he would not let a mere abstract idea stand in the way of public works. ${ }^{125}$ These were Vogel's words precisely, and at this stage, the two men were in perfect accord. No wonder voters had trouble at times keeping up with Macandrew's policy shifts.

It was Macandrew's style of politics that perplexed and infuriated his audiences whose comments covered the critical compass: one asked 'how does it come about that the tide of popular opinion invariably turns in Mr. Macandrew's favor on the eve of some political change?...The great secret is, he has got diplomatic skill, and his character will

${ }^{124}$ ODT, 9 December 1870.

${ }^{125} S T, 1$ February 1871 printed in the $O D T, 8$ February 1871. 
never be fully revealed until that great day when he occupies a chair of diplomatic economy in the future New Zealand University' ${ }^{126}$ and another said 'he has such wheedling ways. ${ }^{, 127} \mathrm{He}$ was called the Charmer ${ }^{128}$ and an Invercargill correspondent wrote 'Oh doesn't he know how to lay on the butter! So nicely and smoothly, and withal so thickly; and then doesn't he rub it in!' ${ }^{129}$ In addition, his achievements were damned with faint praise because 'the affairs of the province generally are pretty much in the same condition in which he found them. He cannot be said to have improved his position; on the other hand no serious objection can be raised against his administration, ${ }^{130}$ he was still 'the dreaming, speculative, scheming mortal he ever was.' ${ }^{131}$ Perversely, he was also criticised as he had 'proved a helpless tool in the hands of Mr. Vogel and his friends...Last session of the Assembly he adopted willingly the ultra-centralistic views of the present Ministry, and succeeded before he left Wellington in binding Otago hand and foot before the government...If the electors desire to see the ruin of Otago completed, they should again return Mr. Macandrew as their Superintendent. ${ }^{132}$ Unmoved by this dire warning, the voters did return him as Superintendent, in a close-run race against Donald Reid who 'is not under General Government influence-he is believed to be a thoroughly independent man. ${ }^{133}$ Reid did not enthuse everybody: it was said of him 'Like his opponent, he cannot boast of intellectual ability...Mr. Reid, although not among the shining lights of the House, was not classed among the vulgar herd of members. ${ }^{, 134} \mathrm{He}$ wanted no truck with Vogel's grand plan and warned, accurately, that provincial lands would eventually be taken by central government to pay for public works.

Despite his influence in Wellington, Macandrew's popularity in Otago was waning where he was criticised as 'the only man who will go to the Assembly from Otago who will blindly support the present Ministry in this obnoxious policy. ${ }^{135}$ He narrowly won the Superintendency for a third time with just $52 \%$ of the vote- Reid beat him by one hundred and forty votes in Otago but Macandrew was saved by Southland where he outstripped

${ }^{126}$ ST, 27 September 1870.

${ }^{127} T T, 13$ October 1870.

${ }^{128}$ Ibid., 20 October 1870.

${ }^{129}$ OW, 29 October 1870.

${ }^{130}$ ST, 18 November 1870 .

${ }^{131} \mathrm{BH}, 13$ July 1870 .

${ }^{132}$ ODT, 26 December 1870.

${ }^{133}$ NOT, 13 January 1871.

${ }^{134} \mathrm{OW}, 14$ January 1871.

${ }^{135}$ ODT, 9 December 1870. 
Reid by four hundred and twenty-two votes. ${ }^{136}$ In contrast to his 1867 win, Macandrew retained his urban support but he was thoroughly rejected by agricultural Otago. He did claw back support in Central Otago, to the bemusement of one editor who considered 'Mr. Macandrew has altogether been such an extraordinary man, and the people of Otago have behaved in so strange a manner towards him, that nothing which he or they could do with reference to each other would excite astonishment. ${ }^{137}$ So it is unlikely that anyone in Otago was surprised when Macandrew showed his ruthless side and had his revenge on Reid. Alternatively, it may have been just pragmatic politics, an opportunity to remove a rival. On his reappointment as Premier in September 1872, Stafford had appointed Donald Reid as Minister of Public Works, a position established in 1870 to oversee the implementation of Vogel's plan. Reid had been Provincial Secretary for Macandrew since May 1869 and his opposition, especially on the sale of waste lands, had frustrated Macandrew, who was angered further when Reid incited a Council revolt against implementing the public works plan in Otago. Macandrew promptly used Reid's Ministerial appointment as a justification for dismissing him as Provincial Secretary, claiming the two positions were incompatible and he went to considerable lengths to get rid of Reid, making two voyages to Dunedin in September during House sittings to dismiss Reid and organise his replacement. ${ }^{138}$

When the Council met in 1871 its composition was considerably altered, to Macandrew's detriment. The forty-six member Council had seventeen new members, most of whom supported Reid's view of provincialism which gave him a twelve-member majority. ${ }^{139}$ Council had lost 'many 'Macandrew-worshippers'-men who vote as their chieftain bids, and load him with fulsome gratitude for telling them what to say and how to act' and deadlock soon emerged. ${ }^{140}$ Macandrew was becoming increasingly isolated from his own Council.

In Macandrew's other electoral race on 31 January 1871, he was decisively rejected by the agriculturalists of Clutha and replaced by James Thompson who won almost three times as many votes as Macandrew. This was the only electoral loss of Macandrew's career, apart from his prison race, and his place in the Assembly was only secured by the

${ }^{136}$ Ibid, 1 March 1871. Macandrew 3,365 votes, Reid 3,015.

${ }^{137} \mathrm{EP}$, quoted in $O D T, 28$ February 1871.

${ }^{138} T T, 5$ September 1872 records his first departure from Wellington on the Luna; NOT, 27 September 1872 records his second departure on the Nebraska; ODT, 15 November 1872 records Reid's dismissal on 25 September 1872.

${ }^{139}$ ODT, 11 April 1871.

${ }^{140}$ NOT, 9 May 1871. 
voters of Port Chalmers who returned him comfortably on 16 February 1871. In Wellington the House of Representatives had an even bigger turnover, with thirty-nine members out of seventy-eight newly elected, and it was suggested that nearly all of the new Middle Island members were separationists. ${ }^{141}$ However, in the absence of Vogel on official business in the United States and Great Britain from January to August 1871, Fox was reluctant to honour his August 1869 promise to consider questions involving fundamental Constitutional changes.

In this power vacuum, the Council, encouraged by the return of Southland, resentful still of subsidising the North Island peacemaking efforts, and ever hopeful that the Middle Island might win autonomy, supported a motion 'that the Province of Otago protests against the further waste of its revenues in the North Island; and this Council requests the co-operation of the other Middle Island Provinces, and especially of our powerful neighbour, Canterbury, to put a stop to it.' ${ }^{142}$ As it evolved this motion demonstrated a range of different Otago attitudes to isolationism and racism, being amended from its original 'further waste of its revenues in Maori Wars in the North Island' to 'further waste of its revenues on the Maoris in the North Island' to its less inflammatory final version. The Council further demonstrated its disapproval of the central government action by punishing its supporters-Reynolds, who held portfolios continuously in the four Ministries from 1872 to 1876 , was dismissed as Council Speaker and the Superintendent's salary was reduced to $£ 900$ (it was reduced to $£ 800$ the next year but was returned to $£ 1,000$ in 1873). Macandrew now had to deal with a stone-walling Council which rejected his usual technique of seeking compromises.

By 1873, the relationship between the Council and Superintendent had deteriorated so badly that Macandrew dismissed it after nine sitting days and called for fresh elections. A rancorous Donald Reid had opposed Macandrew constantly and in the address-in-reply called the appointment of the current Executive Council unconstitutional. The Council had refused to reply to any of Macandrew's messages and twice rejected his nominations for the Executive Council. ${ }^{143}$ In frustration Macandrew wrote that 'it is manifest, therefore, that the majority of the Council, by seeking to force upon his acceptance advisers, who, it may be, entertain entirely opposite views from the Superintendent, are seeking to place

\footnotetext{
${ }^{141}$ EP, 27 February 1871; WI, 4 February 1871.

${ }^{142}$ V. and P., OPC, Session XXIX, 11 July 1871, p. 88.

${ }^{143}$ Ibid., Session XXXI, 8 May 1873, p. 10.
} 
him in a false position - a position which he refuses to accept. ${ }^{, 144}$ This situation was inevitable when the Superintendent and the Council disagreed: it was a stumbling block in the Constitution Act which Vogel modified with The Province of Westland Act 1873 in which the Superintendent was reduced to chairman of the Council and bound by its decisions.

Despite his Council's hostility, Macandrew's snap election gamble paid off: on 18 June 1873 he defeated John Gillies and was elected Superintendent of Otago for the fourth time, with $59 \%$ of the vote, an increase of $7 \%$ on his 1871 result. Southland, in reversing their support of the last election, was the only region which rejected him decisively. Although nineteen of the forty-six Councillors were replaced, the opposing sides were almost evenly balanced, and when they met in July 1873, Macandrew expressed a wish to bury the hatchet. ${ }^{145}$ On closing the session, he congratulated them on the amount of business, mostly local, disposed of in a comparatively short space of time. ${ }^{146}$ The next year he greeted Councillors with the positive news that 'the past year has been one of marked prosperity, and that throughout the Province generally the manifestations of progress have never been greater than at present.' Immigration from the United Kingdom for the last twelve months had been 4,407 and there had been 3,168 births. He noted the huge demand for timber and the importance of conservation and observed that 'the subject is at present engaging the attention of the Colonial Government, with a view to legislation by the General Assembly.' Otago 'possesses in its forests a mine of wealth' which had to be protected. ${ }^{147}$ Donald Reid returned for another term as Provincial Secretary on 6 May 1874, prepared to sell land and raise loans to fund local public works. This presaged a period of co-operation with Macandrew during which time they formed a close alliance to oppose Vogel.

The year 1875 began badly for Macandrew, as Eliza died on 28 February after a long illness. He was 55 years old and although four of his children were adult, the four younger ones were aged from eight to sixteen years old and were now his sole responsibility as both his parents-in-law were dead. He owned the house at Colinswood, but Eliza, knowing his financial habits, had left the land in trust for their children. ${ }^{148}$ The Superintendency was time consuming, requiring travel within the Province while the

144 Ibid., 19 May 1873, p. 14.

${ }^{145}$ ODT, 1 July 1873.

${ }^{146}$ V. and P., OPC, Session XXXII, 30 July 1873, Superintendent's Message, p. 113.

${ }^{147}$ Ibid., Session XXXIII, 29 April 1874, Superintendent's Address, pp. 1-5.

${ }^{148}$ Last Will and Testament of Eliza Hunter Macandrew: ANZ, Dunedin, DAAC D239 23435. 
General Assembly continued to take him to Wellington for long periods. His stress was increased by his conviction that Vogel's unsuccessful 1874 Assembly resolutions would result in abolition of all the provinces. ${ }^{149}$

His pessimism showed when he opened the Council on 3 May 1875-unbeknownst to members, this was their last session - where he noted the attainment of its majority and rejoiced in the province's prosperity: 'It is a remarkable fact that there are only four Colonies in the British Empire, the amount of whose revenue, trade, and commerce exceeds that of this Province' but he lamented that 'there are some amongst us who think that this Province is unfit to manage its own affairs. ${ }^{150}$ On Constitutional Change he declared: 'Of one thing I am certain, and that is, that there can be no partial abolition, but that so long as New Zealand is one Colony, the Provinces, both North and South, must stand or fall together, unless in so far as they may mutually agree to a voluntary fusion such as in the case of Otago and Southland' and he predicted that the central government would now take all revenue and probably all land reserves. He continued: 'It therefore becomes us to guard most watchfully against an organic change in the Constitution, which I am persuaded will prove to be as the letting in of water as respects the future disposition of the Provincial estate.... Why should the people of Otago submit to their resources being still further swallowed up in the maelstrom of Colonial finance?' His solution was to keep the provinces, adopt a federal system and aim for the eventual financial separation of the two Islands: he warned against renouncing the local self-government they now possessed. Finally, although he expected to be called reactionary, he swore 'that were this the last day of my official existence, the opinions now expressed are those which would be honestly held by me.' The Council was noncommittal and replied that modifying the Constitution should be done carefully and slowly and more information was needed before they would agree to any change. They supported Macandrew by passing a motion which called for proposed changes to the system of Government to be tested by a general election.

The response to Macandrew's speech was predictable and in Otago his detractors bridled. The Bruce Herald now turned on him and wrote: 'For New Zealand as a colony, for a country to which in its entirety, he owes allegiance, gratitude, and respect, he has not a word' and for the outliers, Provincial Government was the worst sort of centralism as 'it

${ }^{149}$ NZPD, Vol. 16, 13 August 1874, p. 581. Vogel moved that 'the provincial form of government in the North Island should be abolished; and that... Wellington to be the seat of government of the Colony, and for continuing the localization of the land revenue with what is known as the compact of 1856 .'

${ }^{150}$ V. and P., OPC, Session XXXIV, 3 May 1875, Superintendent's Address, pp. 5 \& 6; Reply, 5 May 1875, p. 10; 15 June 1875 , p. 111. 
agglomerates in a city the influence and the revenue which should be at the disposal of separate districts. ${ }^{151}$ Macandrew's policy reversals, from his 1871 resolutions to his 1875 solutions; from establishing one Middle Island province to retaining the present provinces; from reducing administration costs by abolishing the Middle Island provinces to curbing 'departmental expenditure by provincialism'; from supporting County Boards to abhorring their costs: all were skewered: an ambivalent editor wrote 'We are disciples of $\mathrm{Mr}$. Macandrew, but not the Mr. Macandrew of to-day. We want such principles as he once avowed to be triumphant, and we put him forward as our best advocate. ${ }^{152} \mathrm{He}$ answered his critics through his Port Chalmers constituents in July 1875 and defined himself as a 'thorough Separationist. ${ }^{, 153}$ Should the Government try to change the constitution 'I shall be found in the opposition lobby upon every question affecting the existence of the Ministry.'

The passage of the Abolition of the Provinces Act, 1875 which disestablished the provinces is dealt with in detail in the next chapter. Macandrew opposed it energetically and when he returned to Dunedin at the end of the parliamentary session his efforts were recognised by a banquet where he was feted by more than four hundred diners. Erstwhile critics were quick to praise him and Macandrew was hailed as a man 'who has gone through as many ups and downs of popularity and disapproval as would content some twenty ordinary men. Just now, he is at the very tip-top of prosperity, and a more substantial token of approval would not be amiss than a mere banquet.' ${ }^{154}$ Another newspaper suggested 'We suppose that a more popular man than James Macandrew does not exist just now in New Zealand.' ${ }^{155}$ Macandrew responded fulsomely to the toast, claiming that three great blunders had been committed 'to which most of the political evils to which New Zealand has been heir may be attributed, and but for which the Colony might have been a political paradise.' ${ }^{156}$ The functions of the Colonial and Provincial Parliaments had not been strictly defined and 'each made supreme in its own sphere'; second, the Legislative Council had not been nominated or elected by the Provincial Councils; and the third was 'the anomaly of responsible Government in the Provinces, without the power of appeal to the people.' An escape from 'despotic Centralism' was

\footnotetext{
${ }^{151}$ BH, 7 May 1875.

${ }^{152} S T, 19$ May 1875.

${ }^{153}$ ODT, 16 July 1875.

${ }^{154} O W, 9$ October 1875.

${ }^{155}$ ODT, 23 October 1875.

${ }^{156}$ Ibid., 28 October 1875.
} 
urgently required. If Macandrew had been successful in securing his model, an Upper House elected by the provinces, New Zealand politics today would be a very different process.

Deterred by law from assembling the Otago Provincial Council in 1876, Macandrew wrote a Final Report in which he predicted that concentrating of power in Wellington would be the 'prelude to years of departmental extravagance, political turmoil, and well founded local discontent which cannot fail to exercise a most baneful influence upon the advancement of the Colony in general and of Otago in particular. ${ }^{157}$ His report painted a glowing picture of Otago as a province at its peak, with a public revenue for the year of $£ 1,058,104,1,573$ births, 5,132 immigrants landed, 108,791 ounces of gold retrieved, 162 public schools operating, 102,094 acres of rural land sold and 202 miles of railways operating at a profit. ${ }^{158}$ It also highlighted the changed nature of the Superintendent's role. Once Otago's infrastructure had been established, the Superintendent's main responsibility was the effective administration of a unified and developed, albeit miniature, state. Macandrew could argue that the "the peace, order, and good government of the Provinces" had been achieved and that Otago was functioning profitably after ten years of his rule, thus it was illogical that it should be abolished. It is no surprise that his report ended with these words: 'What would be thought of Congress were it to abolish the States of America without consulting the several States, and they themselves dissenting? The very idea is preposterous, and yet this is precisely what is sought to be done in the case of Otago., ${ }^{159}$

When Macandrew addressed a large rally in Dunedin on 27 September 1876estimated as up to 2,000 protestors - he brought the house down by declaring 'I dare say some people will think me heterodox. But I have reflected over it a good deal, and am of opinion that the only way to save Otago is to erect into a separate Colony...by having recourse to the Imperial Parliament. ${ }^{160}$ His mission to preserve the provinces had taken him from support of a decentralised system of governance to complete isolationism.

Following this meeting, Macandrew sent a telegram to the Governor indicating the strong Otago opposition to abolition and asking him to refrain from assenting to the

\footnotetext{
${ }^{157}$ Province of Otago, Departmental Reports and Other Papers, 10 June 1876, pp. 1-5.

158 Letter: Daniel Pollen/Vogel, 19 October 1876, ATL, MS-papers-2072-Folder 25. The Colonial Government's target at this time was 5,000 immigrants annually.

${ }_{159}^{150}$ Province of Otago, Departmental Reports and Other Papers, 10 June 1876, pp. 1-5.

${ }^{160} \mathrm{BH}, 29$ September 1876.
} 
Abolition Act. ${ }^{161}$ In it he issued a warning: 'I venture to say that the actions of your advisers in respect of this Province must, if persisted in, result in a dismemberment of the Colony.' The Otago Provincial Council was being urged to hold a plebiscite and would send its result to the Imperial Government 'who, it is confidently hoped, will not turn a deaf ear to what I believe will undoubtedly be found to be the deliberate and unmistakeable desire of an overwhelming majority of the settlers of Otago.' Premier Atkinson, in a memorandum advising the Governor, stated 'He [Macandrew] appears to forget that the Abolition Act is now law, has been left to its operation by Her Majesty, and will come into force without further legislative action.' He added that if Macandrew thought amending the Constitution was ultra vires, the courts of law were open to him. As usual, Macandrew had to have the last word and telegraphed back that it only remains now to appeal to the Imperial authorities in the hope that what is understood to be the law of the Empire will be maintained - namely, that constitutional privileges once granted to a people are never taken away without their consent.' He enclosed a copy of a telegram he had sent on 6 October to the Secretary of State for the Colonies which included the words 'Have honor suggest said Act be referred to her Majesty's Attorney General with view disallowance if void. Deep feeling wrong pervades Province. ${ }^{162}$

His staunch although erratic ally, George Grey, had also written to the Governor and telegraphed the Secretary of State, using even more incendiary language: 'Disturbances imminent. Some threaten employment Queen's ships. I earnestly pray telegraph to prevent disturbance. ${ }^{163}$ Lord Carnarvon's prompt reply endorsed the Act which 'cannot be disallowed' and was dismissive of the risk of 'unconstitutional disturbances. ${ }^{164}$ With that, the Abolition Act became law on 1 November 1876, with few regrets and little rejoicing throughout the land. It came into force on 1 January 1877 , twenty-four years and six months after the passing of An Act to grant a Representative Constitution to the Colony of New Zealand on 30 June 1852.

Macandrew's final protest included the defunct Council's members. On 8 November 1876 he opened a two-day conference in Dunedin for Members of the House of Representatives and the Provincial Council, Mayors of Municipalities, Chairmen of District Road Boards and of local Education Committees to 'determine the best means of

\footnotetext{
${ }^{161} O W, 7$ October 1876 printed Atkinson's memorandum and Macandrew's reply.

${ }^{162}$ GRA, 14 October 1876.

${ }^{163}$ Marlborough Express, 11 October 1876.

${ }^{164}$ Star, 20 October 1876.
} 
extricating the Province of Otago from the evil results involved in the "Abolition of Provinces Act." 165 Over one hundred attended and heard him declare that "the only panacea for the great wrong which is being inflicted upon Otago is that it should be proclaimed an independent Colony, with a supreme legislature of its own and the absolute control over its own revenues.' Resolutions were passed to petition the Queen, again, this time to proclaim Otago a separate and independent colony, and for Grey and Macandrew to sail to England to personally deliver the petition. Unfortunately, the petition was sent by mail and not through official channels, so could not be presented to Her Majesty. London's rebuff did not arrive until the following June, finally squashing all hopes of reversal for the provincialists. Macandrew had become a separationist zealot, choosing this stance when all else had failed to preserve his precious Otago.

The cost of government ended the provinces and Vogel later asserted: 'I saw the time had come when the country could not support them, or, speaking in plain terms, the system was one which it was beyond the strength of the colony to continue. It was the finance question, as I have said before and probably shall often again say, which made the change necessary. ${ }^{166} \mathrm{He}$ also saw that abolition meant the end of some long friendships, adding that ' $\mathrm{I}$ had not from the time when I took office any stronger supporter or firmer personal friend than the Superintendent of Otago, Mr. Macandrew-I felt for him great esteem; I felt for him an esteem founded on the conviction that there was no man in the colony more disinterested or public-spirited than he was - and yes, I knew, so strong were his feelings in favor of provincialism that his support was likely to be lost to me., 167

In an era of robust characters, Macandrew was conspicuous, a man who was notable for his passion, as well as his persistence and his parochialism. Macandrew was distinguished from most of his fellow politicians by his obsession with Otago's survival which bordered on the manic during this phase of his life, a survival based on a belief that its wealth must not be shared with the remainder of the colony but should be used to improve conditions locally-let the other provinces meet their own needs.

\footnotetext{
${ }^{165}$ Clutha Leader, 3 November 1876.

${ }^{166}$ Speech: Julius Vogel, Banquet at Wanganui, 16 March 1876, ATL, MSY-1337. There were of course, other reasons: Morrell, The Provincial System, p. 270-285, suggests: overextended borrowing; transfer of functions to the centre; decentralisation of other functions to local bodies; provincial extravagance; diversity of legislation and lack of uniformity; land issues; discontent of outliers; growth of national consciousness; growing apathy with politics.

${ }^{167}$ Speech: Julius Vogel, Banquet at Wanganui, 16 March 1876, ATL, MSY-1337.
} 
Macandrew's modest origins offended some of his colleagues, by virtue of his Scottishness, or perhaps, because he was not quite a gentleman. A fellow Superintendent and Member of Parliament once asked a colleague 'Are you going to join the University Council with Macandrew upon it? I have given no answer yet as I wish to hear whether the other members would protest against such an enormity.' ${ }^{168}$ His origins doubtless undermined his support in Wellington but had the opposite effect in Otago. His behaviour certainly offended others, leading another correspondent to note: 'I for one am not sorry that that big rascal is at last meeting with his deserts, and that at the hands of those through whose assistance he climbed into power. Honest conscientious men who have hitherto been driven out of any say in public affairs will now have a chance of letting their voice and influence be felt without coming under the wing and patronage of "slippery Jim".,169

That Macandrew appealed to the Otago voters and was an outstandingly successful politician is indisputable. He won seventeen of the nineteen elections he contested in his lifetime. He won three elections to the Otago Provincial Council and four of the five elections he contested for Superintendent, even coming a comfortable second from his prison cell in his second race for that position, while he lost only one of his eleven Assembly races. In Otago his followers alternately abused him and adulated him but by the ending of the provinces, his career was depicted in reverential terms: 'the time has not yet come to write the history of this remarkable man, but the materials for a most striking biography are most abundant, and the variety of light and shade scattered through an eventful life in Scotland, England, and New Zealand will be read with interest some day.... While there is much in it to warn, there is much to imitate. ${ }^{, 170}$

\footnotetext{
${ }^{168}$ Letter: William Rolleston/Hugh Carleton, 10 December 1870, ATL, MS-77-248-01/4.

${ }^{169}$ Letter: Robert Gillies/William Cutten, 25 October 1875, in Greif and Knight, p. 73.

${ }^{170} \mathrm{OW}, 18$ September 1875 .
} 



\section{CHAPTER 6}

\section{Politician: SeCond CaReER 1863-1876 Wellington}

Political rehabilitation following his imprisonment for bankruptcy was completed in July 1865 when Macandrew was re-elected to the General Assembly for the Seat of Bruce and returned to represent Otago interests in the House after a nine-year absence. During the next decade, Parliament debated governance at every session and the supporters of provincialism were forced on to the defensive as the colony came slowly to accept a model of central government. Abolition was not a sudden decision. Macandrew was a key defender of the provinces in these deliberations and even he admitted, at times, that the provinces' days were numbered. This chapter will assess Macandrew's role in the General Assembly as it moved inexorably towards abolition. The period will be examined in three phases: Stafford's tenure as Premier until 1869, Vogel's term as Colonial Treasurer then Premier until 1874, and the endgame to 1876.

\section{Member of Parliament}

Macandrew's parliamentary standing was enhanced on his return by his adroit shepherding of The New Provinces Act 1865 which safeguarded the original provinces by putting a brake on the establishment of new ones, requiring them to be created henceforth by parliament. ${ }^{1}$ His performance in the House drew favourable comments and lifted his status with one editor writing that 'this gentleman has just been returned as member for Bruce, and is now looked upon as one of the leaders of the Opposition.' ${ }^{2}$ Another correspondent considered that ' $\mathrm{He}$ is evidently a shrewd man, and broaches no subject he is not well up in; but when he does broach it, he brings to bear upon his argument no mean flow of studied language, that rises now and then into true eloquence, albeit tinged with a north of the Tweed accent. ${ }^{3}$

From 1865 until 1876, Macandrew's reputation as one of the Colony's most forceful supporters of the provinces grew, as did his influence. He was reported by the media almost daily, yet surprisingly, he did not achieve cabinet rank in this period. Vogel, elected in 1863 and headed for higher office, provoked a different reaction and a comment passed at the time damned him with faint praise: 'He may say the best thing possible; he may reason in a manner the most cogent and convincing, yet the House listens with dull

\footnotetext{
${ }^{1}$ The New Provinces Act 1865, No. 34.

${ }^{2}$ Timaru Herald, 2 September 1865.

${ }^{3}$ Colonist, 10 November 1865.
} 
ears, or refuses to listen at all. ${ }^{4}$ Vogel's opposition to a stamp duty contributed to the fall of the Weld Ministry on 16 October 1865 and precipitated the appointment of Edward Stafford as Premier, a staunch centralist and no friend of Macandrew or Vogel.

Macandrew had a wide range of interests and spoke on arbitration courts, distillation and an Imperial Loan in 1865, military pensions, postal service and scabby sheep in 1866, the Medical Practitioners Act, missing vessels and the Armed Constabulary Act in 1867, but matters concerning the provinces, steamer services to Great Britain and education were his continuing concerns. After 1870 he spoke regularly on railways and public works. ${ }^{5}$ Prudent fiscal management was a major focus for him in this period and he was always active when the House dealt with Supply, reducing here and cutting there. When Parliament was dissolved on 27 January 1866, Macandrew exchanged electorates, to the new single-member seat of Clutha where, in a display of the high esteem in which he was then held, he was elected unopposed on 9 March. In his acceptance speech he announced his goal, that 'If the Assembly was to do any good at all, the pruning knife must be applied to the gigantic expenditure of late years. ${ }^{6}$ Vogel had to work harder to stay in Parliament-his Dunedin seat was disestablished and after losing in Waikouaiti, he was returned for a Goldfields seat.

In the House, Macandrew wielded his pruning knife and moved a number of extreme cost-cutting measures. He opposed the establishment of Hansard, as an unaffordable luxury and because 'in some other cities in the Colony, local enterprise would undertake the work without subsidy. ${ }^{7} \mathrm{He}$ opposed, unavailingly, a Military Pensions Bill as 'he would any measure which contemplated the continuance of this miserable war which he believed would have been over long ago, if the provinces had the management of their own affairs, both native and European. ${ }^{, 8}$ He moved that 'the duties on imports be henceforth re-adjusted from year to year, so as to realize a sum not exceeding $£ 800,000$ in any one year; the one-half amount of which amount to be legally secured for appropriation by Provincial Councils' and he wanted the same treatment for Customs Revenue and other government income. ${ }^{9} \mathrm{He}$ proposed 'to do away with the

\footnotetext{
${ }^{4}$ Daily Southern Cross, 11 September 1865.

${ }^{5} \mathrm{He}$ spoke on the flax industry in 1870, on forestry in 1874; and on native coal in 1876.

${ }^{6} \mathrm{BH}, 15$ March 1866.

${ }^{7}$ WI, 19 July 1866.

${ }^{8}$ Ibid., 11 August 1866. Macandrew 'objected to a standing army existing in this Colony, for it would be composed principally of mercenaries, and might, some day, in the hands of a faction, become the means of taking away the liberties of the people.'

${ }^{9} \mathrm{BH}, 23$ August, 1866.
} 
whole of the Defence Force, the expenses of the Native Department, and all the Resident Magistrates of the colony. ${ }^{10} \mathrm{He}$ spoke, without any irony given his behaviour while a ship-owner, against the practice of subsidising the Intercolonial and Interprovincial Mail Services 'as an unhealthy one, tending to repress private enterprise' and he complained about the mystery that surrounded New Zealand finance. ${ }^{11}$ His solution was: 'If they made all revenue provincial, they would get out of the difficulty; and then let each Province contribute its due proportion to the General Government. ${ }^{12}$ He opposed a Stamp Tax on the grounds that retrenchment and not taxation was required. ${ }^{13}$ Critics mocked and labelled him an ultra-economist because 'he coolly proposes to sweep away the means of giving peace and security to half the colony. ${ }^{14}$ But he was not dismissed entirely. Some observers saw his tactics for what they were-long-term positioning. At budget time, they claimed, 'these malcontents will be augmented' and the Ministry would have to be ready to refute them. ${ }^{15}$

By this time, Macandrew had served a dozen years in provincial and colonial politics where he had acquired such fame that any criticism levelled at him did little to diminish his fervour and forthrightness. ${ }^{16}$ During a debate on financial policy in 1867 in which he repeated his demand to abolish the Native Department and the Defence Office, he deplored the war against the Maori because 'I believe from the beginning to the end it has been not only a great blunder, but it has been a disgrace to the Colony. ${ }^{, 17}$ He claimed 'that atrocities have been committed in the course of this war on both sides-atrocities which might make humanity blush,' then he dropped a bombshell: 'we have learned over and over again in this House of unarmed men, women, and children-I do not know about the children - but of unarmed men and women having been shot down in cold blood at dead of night by half-intoxicated men-I might rather say demons in human shape. I myself have been told of orgies in the Waikato district.' Uproar ensued but the Speaker ruled Macandrew's words were not disorderly. The Evening Post fulminated: 'It is well for

\footnotetext{
${ }^{10} N E, 1$ September 1866.

${ }^{11}$ WI, 1 September 1866.

${ }^{12}$ Ibid., 29 September 1866.

${ }^{13}$ Daily Southern Cross, 4 October 1866.

${ }^{14} \mathrm{NE}, 1$ September 1866.

15 Ibid.

${ }^{16}$ Wanganui Herald, 14 April 1868: 'Mr. Macandrew is a hard headed man who can bear abuse, criticism, and denunciation, and yet go on in his course as a public reformer, as if he were immaculate, and his denouncers of marked inferiority.'

${ }^{17}$ NZPD, Vol. 1, 5 September 1867, p. 787-788. Macandrew's comments resulted in a Select Committee enquiry into allegations against Lieutenant-Colonel McDonell who had led an attack on natives at Pokaikai in September 1866. McDonell was exonerated.
} 
the credit of this colony that the foul aspersions cast last night by Mr. James Macandrew on the colonists of New Zealand emanated from a person whose unfortunate antecedents are such as to warrant a conviction that having gone so far in a career of social and political immorality, it becomes of little moment to him what sort of weapons he uses, provided they be likely to suit his ultimate purposes. ${ }^{18}$ Macandrew's refusal to retract had an unexpected consequence. ${ }^{19}$

Major Harry Atkinson of Taranaki was particularly antagonistic to Macandrew, possibly because Atkinson's personal involvement in the Taranaki fighting and Macandrew's resentment of that conflict's cost to Otago made them natural opponents. ${ }^{20}$ Atkinson, a centralist, considered that the 'purity of the House' was insufficiently protected by the Constitution Act which barred felons and those convicted of treason from sitting but allowed them to return on completion of their sentences, and did not exclude defaulters and defalcators. He thought that a retrospective ban of these offenders from all public offices, including the Assembly, should include the likes of Macandrew, who had survived only through a lack of parliamentary process. Atkinson's solution was the Public Offenders Disqualification Bill. Vogel protested that the Bill was unnecessary, protection already existed and it would be a monstrous thing to pass a Bill expressly aimed at a member of several years standing in the House. ${ }^{21}$ Reynolds considered it should be sponsored by the Government although he would disqualify anyone 'who would not be admitted into respectable society, either for high treason, drunkenness, or open immorality.' Vogel's attempt to postpone the reading for six months was lost, the Bill became law but without the retrospective clause, and Macandrew's career was saved. During the debate Macandrew was absent 'for once and the first time in his known career. He did not brave

${ }^{18} E P, 6$ September 1867.

${ }^{19}$ NZPD, Vol. 1, 15 August 1867, p. 481-84. Macandrew also attempted to reduce central government's expenditure by opposing the formation of an Armed Constabulary Force: he demanded that 'the Middle Island should take the stand, and protest against being compelled not only to support its own police but to support the police of the Northern Island also.' The Armed Constabulary Bill's Second Reading was passed by 40 votes to 5 (Macandrew, Vogel, Reynolds, Burns, Graham were opposed); Ibid., 26 September 1867, p. 1126. Macandrew also moved to abolish the subsidy on inter-provincial mail services but even Vogel opposed him on this issue.

${ }^{20}$ Harry Atkinson, (Major, later Sir) 1831-92, farmed in Taranaki from 1853, Member Taranaki PC 1857-65, 1873-74, Taranaki Executive Council 1868, 1874, Deputy Superintendent 1861-62, MHR 1861-69, 187291, MLC 1891-92, Minister Colonial Defence (Weld Ministry) 1864-65, Minister of Crown Lands and Immigration (Vogel Ministry) 1874-77, Colonial Treasurer, Minister of Crown Lands and Immigration (Pollen Ministry) 1875-76, Minister of Crown Lands, Immigration and Customs (Vogel Ministry) 1876, Colonial Treasurer, Minister of Customs and Stamp Duties (Hall Ministry) 1879-82, Colonial Treasurer, Minister of Customs, Stamp Duties and Marine (Whitaker Ministry) 1882-83, 1887-91, Premier 1876-77, 1883-84, 1887-91, KCMG 1888.

${ }^{21}$ NZPD, Vol. 1, 31 August 1867, p. 515 onwards. The Bill was enacted as the Public Offenders Disqualification Act 1867, No. 49. 
the storm that would have burst upon him had he ventured to expose himself to it' and he did not vote in the division. ${ }^{22}$ His guilt had been not proven although it was commonly accepted as manifest but nothing was said in his defence except that 'time should have whitewashed him from the consequences of the crimes with which he has been charged, and which he has never even attempted to dispute the truth of.' Once the initial resentment at Macandrew's return had subsided, he was acknowledged as a member of an increasingly influential parliamentary faction and was treated with a certain amount of respect as a Superintendent with the status of a Lieutenant-Governor. Wellington life freed him from the everyday administrative tasks of a Superintendent and from the demands of Otago lobbyists.

\section{STAFFORD AND THE PROVINCES 1865-1869}

Macandrew had no sooner returned to Parliament than a debate was precipitated over a report which Governor Grey had undertaken to send to the Secretary of State in January 1865 regarding the separation of the Province of Auckland from the southern portions of the colony. ${ }^{23}$ Premier Weld denied the existence of such a report but on 7 September 1865 the Legislative Council agreed on the necessity of the colony remaining 'one and undivided. ${ }^{24}$ The same day, an Auckland member, Thomas Russell, presented a four part motion to the House, suggesting that it was time to adjust the Colony's liabilities amongst the provinces; that New Zealand should be divided at Cook Strait, into two separate colonies; that the Governor should be asked to appoint a Deputy-Governor to administer the Province of Auckland, and that a bill should be introduced to make this happen. ${ }^{25}$ Julius Vogel, in his separatist phase, supported the motion, claiming 'the Middle Island could not afford to retain the connection, in justice to its own creditors; therefore he eagerly welcomed the offer made by the North Island, to make no further claim on the Middle Island if the Middle Island would only leave to it the boon of self-government.' He suggested that cheaper Imperial troops be retained for garrison duties, even with the resulting British influence in New Zealand affairs that their presence created, to avoid increasing taxation on the colonists, especially in the Middle Island. ${ }^{26}$ Macandrew cast his lot in with Auckland although he regretted the possible outcome and was reported: 'the breaking-up of the colony would be the breaking-up of all the aspirations which he and

${ }^{22}$ Hawke's Bay Herald, 3 September 1867.

${ }^{23}$ NZPD, 2 August 1865 , p. 236.

${ }^{24}$ Ibid., 7 September 1865, p. 432.

${ }^{25}$ Ibid., p. 438.

${ }^{26}$ Ibid., p. 452. 
others had cherished for many a long year. ${ }^{27}$ Nevertheless, he supported a political and financial split between the two islands if the Government would not change its policy and stop taxing the Middle Island to pay for the war in the North Island. An amendment that 'New Zealand ought not to be divided into two or more separate colonies' focused the debate. ${ }^{28}$ However, after four days of debate, despite their passionate pleas, the separationists could only raise seventeen votes to the Government's thirty-one and the colony remained united. Surprisingly, Vogel refrained from voting in this division. ${ }^{29}$

The 1866 Parliamentary Session opened with uncertain prospects. Fighting in the North Island had eased and rumours were afloat that the Colonial Office would put 'the veto of the Crown upon any proposal to dismember the colony... separation in its simple form is, for all practical purposes, disposed of for the present. ${ }^{, 30}$ This prediction did not stop the Auckland Superintendent and parliamentarian Fredrick Whitaker from moving on 24 July 1866 that 'temporary provision should be made for the better government of the Province of Auckland' and his ten proposals to achieve this end included converting the Auckland Provincial Council into a Provincial Assembly with a greater degree of selfgovernment. ${ }^{31}$ But if Auckland were to achieve self-government, the Middle Island would have to continue to subsidise the remainder of the North Island provinces.

Whitaker's motion was not welcomed by the Otago contingent and Superintendent Dick moved an amendment to grant all the provinces self-government-which was lost. ${ }^{32}$ Vogel supported Dick in criticising the resolutions as exclusively Auckland-focused when they should apply to all the provinces. ${ }^{33}$ Three days later, Vogel used Macandrew's argument when claiming that the provinces would die out when they were not needed but there was no need to cripple them now. Vogel considered that "when the iron horses ran through the two Islands, then they would have no more need of provinces; but as yet they had only done half their work. ${ }^{34}$ Macandrew also supported Dick and made a forceful contribution to the debate. He staked his claim when he announced that if ultraprovincialism was to encourage the development of the resources of the colony, and to carry out the object of introducing population into the country, then he was an ultra-

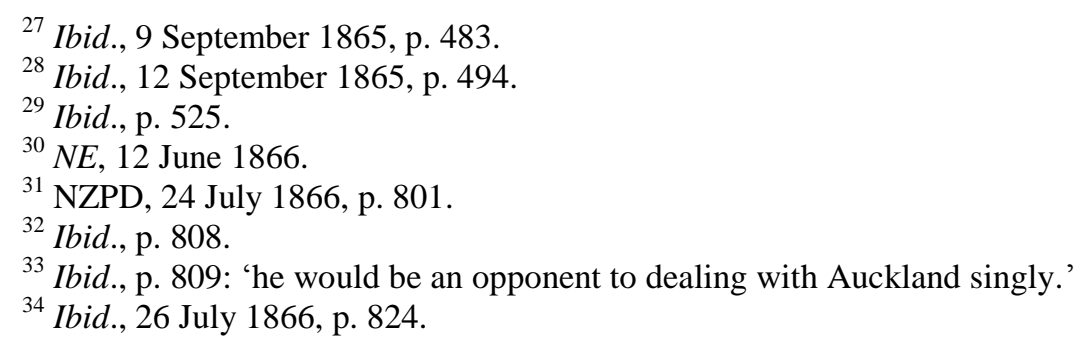


provincialist and was proud of being so. He desired to see the Province of Otago, for example, having the fullest control over its own affairs, that it might ultimately outshine, and perhaps absorb, the Province of Canterbury,' a sentiment which would have upset his neighbours. ${ }^{35}$ But Whitaker, Dick, Macandrew and Vogel were a minority and Whitaker's original motion was lost by forty-four votes to eighteen. Yet again, Vogel did not vote in a debate on separation. ${ }^{36}$

A week later, the provincialists were further distressed by Colonial Treasurer Francis Jolie's Financial Statement which reduced the provinces' usual three-eighths share of the customs revenue and introduced a stamp duty, brought about by a rapid increase in the central government's financial requirements. As a result, provincial budgets would be short-changed and their development stalled. ${ }^{37} \mathrm{~A}$ want-of-confidence vote ensued which served only to reinstate Stafford with a stronger Ministry, including Otago member and Speaker of the Provincial Council Richardson, and further alienated Otago and Auckland members who considered that 'an unchecked Stafford might destroy the system for the sake of his obsession with colonial unity., 38

When the latest version of the Otago Waste Lands Bill was presented to Parliament, Macandrew argued for complete provincial control of waste lands. ${ }^{39}$ However, he did not support a call from Otago gold miners to reject the unwieldy and inefficient shared administration of the Goldfields. ${ }^{40}$ They were administered by the provinces under delegation from the central government and Macandrew, supported by fellow provincialists, requested the Goldfields Select Committee to consider whether 'the power of legislation might not also with advantage be extended to Provincial Legislatures; or whether the administration as well as the legislation ought not to be in the hands of the General Government.' ${ }^{41}$ Whitaker added 'give us the whole management or take it yourself. ${ }^{42}$ Surprisingly, given his views on local self-government, Macandrew favoured

\footnotetext{
${ }^{35}$ Ibid., p. 821.

${ }^{36}$ Ibid., 31 July 1866, p. 845. Four of the six Superintendents in the House (Donald McLean, Isaac Featherston, William Eyes, William Moorhouse) voted against Whitaker and Dick.

${ }^{37}$ Morrell, The Provincial System, p. 178. The stamp duty was introduced on 8 August 1866.

${ }^{38}$ Lyttelton Times, 20 August 1866, quoted in Bohan, Edmund, 1994, p. 227. Colonial unity was sardonically defined as 'that deplorable notion that there was a wider community of national interest beyond mere local self-interest.'

${ }^{39}$ NZPD, 24 August 1866, p. 895.

${ }^{40}$ ODT, 23 July 1866.

${ }^{41}$ Daily Southern Cross, 31 July 1866.

${ }^{42}$ NZPD, 24 July 1866, p. 796. Frederick Whitaker raised this issue in the Separation debate.
} 
central control while Vogel wanted to retain provincial management. ${ }^{43}$ The Goldfields Committee recommended retention of the status quo but this unremarked interlude foreshadowed an intense dispute which occurred the following year when control of the goldfields became a political issue of consuming intensity. ${ }^{44}$

Macandrew's re-election as Superintendent in February and the stalemate which developed over the management of the Otago goldfields precipitated a continuing debate on provincial powers in the 1867 Session of Parliament. Battle lines were drawn about Vogel who moved that the Governor's powers under the Gold Fields Act should be delegated to the Superintendents whose provinces contained the fields, a motion which Stafford amended with the addition of 'saving in exceptional cases. ${ }^{45}$ Stafford won by just twenty-eight to twenty-four votes. ${ }^{46}$ Ten of the thirteen Otago members present opposed the amendment, and supported by ten of the fourteen Auckland members and three of the seven Wellington members, were described as 'the strong provincialist party, now fully alive to the necessity of unified action in withstanding any further inroads upon the rights of the provinces. ${ }^{47}$ A face-saving compromise rescued Stafford's Ministry, with the passage of the Gold Fields Act Amendment Act 1867 and the Governor's Delegations Act 1867 which assigned the Governor's powers to Provincial Executive Councils. But Stafford was not deterred from his quest to reduce the powers of the provinces, if not remove them altogether, to strengthen the centre.

The Constitution Act had provided for the creation of municipalities and the provinces possessed the authority to establish boroughs and road districts. The earliest town board created had been Dunedin in 1855 and the General Government had come under increasing pressure from outlying districts to delegate further, regulate uniformly, and fund self-government for ever smaller units of local government. These demands encouraged Stafford to continue to undercut provincial powers and he responded to Westland's plea for independence from Canterbury with the County of Westland Bill which created a modified province 'less cumbrous and costly,' funded by central government and with the Superintendent's powers retained by the Governor but delegated to a County Council. He also tabled the Timaru and Gladstone Board of Works Bill which

\footnotetext{
${ }^{43} N E$, 26 July 1866: 'The conclusion would seem to be that the General Government must recall the letters of delegation. The mover (Macandrew), and Mr. Dick, the Superintendent of Otago, declared that they would prefer this to the present arrangement.'

${ }^{44}$ ODT, 12 September 1866.

${ }^{45} \mathrm{BH}, 24$ July 1867.

${ }^{46}$ Wanganui Herald, 10 August 1867.

${ }^{47} \mathrm{BH}, 31$ July 1867.
} 
gave limited local use of provincial revenue to a grouping of road boards and a municipality. ${ }^{48}$ Both Bills were enacted with little fuss.

Few were surprised at Stafford's next move, designed to further reduce provincial powers. He introduced, at a particularly inauspicious moment given the animosity arising from the goldfields delegation debate, a Municipal Corporations Bill and a Local Government Bill. The former consolidated provincial enactments and established municipal bodies to levy rates and administer communities of over one hundred and fifty householders, and was passed, despite Macandrew's predictable contention that 'it seems a most expensive and cumbersome machinery for the purpose of performing functions which the Provinces are performing very satisfactorily for themselves' especially as Otago already subsidised its municipalities. ${ }^{49}$ The latter bill provided the means of funding the municipalities, by subsidy and by endowment from provincial land funds and proved to be one step too far for the Opposition. ${ }^{50}$ The Bill was defeated twenty-seven votes to thirtysix, a reversal for the Government who denied it was a want-of-confidence vote and clung to power. That the Otago pair of Macandrew and Vogel were now, de facto, leading an effective Opposition was such a fearsome prospect that one editor defended the Ministry's retention of power on the grounds that 'to keep out a Ministry led by Mr. Vogel and Mr. Macandrew, is an object which ought to be important to every one who wishes to save our institutions from deserved contempt. ${ }^{, 51}$

The perennial politician and periodic Premier, William Fox, returned to the House of Representatives in 1868 , refreshed by a three year spell abroad. ${ }^{52} \mathrm{He}$ galvanised the General Assembly, united opposition to Stafford, revitalised the provincialists, and recharged the alliance between Macandrew and Vogel. Fox's energy regenerated a House which was floundering in the face of Maori resistance, economic decline and the deadlock between central and provincial legislatures. Early in the Session he accused the Ministry of

\footnotetext{
${ }^{48}$ Morrell, The Provincial System, p. 193-6. The Bills became the County of Westland Act 1867 and the Timaru and Gladstone Board of Works Act 1867; Timaru Herald, 5 February 1868. Timaru and Gladstone settlers petitioned the Assembly five times in 1866-7 while Westland requested separation on the grounds of 'diversity of interests, distance from the seat of Provincial Government, and difficulty of communication, insufficient representation, injudicious legislation, parsimonious expenditure, and excessive cost of administration.'

${ }^{49}$ NOT, 27 August 1867.

${ }^{50}$ Morrell, The Provincial System, p. 192-3.

${ }^{51}$ NE, 20 August 1867.

52 William Fox, (Sir), 1812-93. Lawyer, landowner, Resident Agent N.Z. Company, Nelson 1843-48, Principal Agent N.Z. Company, Wellington 1848-50, Member Wellington PC 1854-62, Wellington Executive Council 1854-58, 1861, MHR 1855-65, 1868-81, Colonial Secretary (Whitaker Ministry) 186364, Premier 1856, 1861-62,1869-72, 1873, KCMG 1879.
} 
drifting and instigated a fortnight-long debate on Stafford's provincial and Maori policies. ${ }^{53}$ Initially, Stafford denied any wish to destroy the provinces and claimed that he had increased their powers, but he did admit that 'at the present moment some of the Provincial Governments are excrescences.' When he acknowledged that 'we are not going to propose one universal scheme to be substituted for the Provinces - it is now too late', members knew that creeping change was underway and the Roads Boards Districts, the County of Westland, the Timaru and Gladstone Board of Works, were evidence of a Government determined on change. ${ }^{54}$ It was a persuasive Macandrew who now emerged to sway the House.

A week into the debate, Macandrew claimed that eighteen months earlier, he had heard a Minister at a banquet state that the policy of the Government was to gradually undermine the Provinces. He now stated that their policy to subvert the Constitution would be "insidiously, and by a side wind. ${ }^{55}$ But Macandrew considered that the country could pull itself out of recession by increasing immigration and investment in infrastructure and he allowed that "when there are two millions of people in the country instead of two hundred thousand, it will be time enough to talk of the provinces having accomplished their mission.' Progress would come by 'leaving the Provinces free and unfettered to carry out the great colonizing work which they, and they alone, have hitherto undertaken, and which they alone are capable of carrying on...I want to see the provinces striving against each other in the great work of colonizing these islands.' He suggested that each province should keep all the revenue it raised, pay a levy to maintain a federal government and the North Island should be left to sort out its Native problem by itself because he doubted that 'the Provincial Government of Taranaki would have carried on a war with the Natives at its own cost.' In the meantime he considered it absurd to have two bodies to do one thing: 'If the General Assembly is to legislate for the peace, order, and good government of the Provinces, what necessity is there for keeping up the Provincial Legislatures?...If the Provincial Legislatures are to be abolished, give them their quietus at once.' He suggested appealing to the country to decide but warned that the General Assembly might end up being the body abolished. His contribution to the Native affairs question was simple. He claimed: 'I must say that as a Middle Island member I am utterly unable to comprehend these Native questions' and he would be prepared for the Middle Island to take over the

\footnotetext{
${ }^{53}$ NZPD, Vol. 2, 30 July 1868, pp. 185-149.

${ }^{54}$ Ibid., p. 197.

${ }^{55}$ NZPD, Vol. 2, 7 August 1868, pp. 362-5.
} 
colony's Three Million Loan if the North Island would provide peace, order, and good government for their Natives as well as Europeans. He reiterated his desire to abolish the Native and Defence Offices.

Fox's motion was lost by just nine votes, and was a warning to Stafford. ${ }^{56}$ As a peace gesture to the provincialists, Stafford supported a Vogel motion to allow provinces to use their own land revenue and to make their own arrangements for immigration. Macandrew supported it and accepted some reflected glory. He claimed the motion was based on an Otago Provincial Council proposal to 'land from 25,000 to 30,000 immigrants on these shores within the next few years' and extolled his own experience in immigration matters-he claimed that Labour plus Capital was the necessary formula. Ever the pragmatist, Macandrew lectured the House on the need for statesmanship, 'not the statesmanship which delighted itself in enrolling and controlling standing armies... what they required was a statesmanship which would bridge the 16,000 miles of ocean which separated them from the mother country. ${ }^{57}$ Here was yet another example of Macandrew having the last word.

Fox attacked Stafford again and moved another want-of-confidence division. Macandrew could not resist making a contribution and once more he addressed the partnership between the General and Provincial Government but this time he admitted that his view was 'somewhat peculiar' because he recommended that the provinces retain all their revenue and each province pay its own debts. ${ }^{58}$ Ports and harbours, he suggested, of all infrastructure, should be locally funded and controlled. He commented on the Native question again, as the head of the province that paid nearly one-third of the Colony's taxes, that 'the indefinite liability of the Middle Island for native purposes must cease.' He followed this with an astute and heartfelt appeal which would have challenged his listeners. If the Government 'could not procure sufficient land in the North Island then go to the Middle Island, where there was enough and to spare, only in heaven's name don't let us have any more fighting about it, for after all, the whole war was about land, and he believed that a fraction of the money which had been expended on gunpowder would have acquired the whole Northern Island by purchase, had the settlers been left to deal with the subject.' Although Fox could not persuade his colleagues to support his motion, time was running out for Stafford's Government. Macandrew and Vogel were now counted amongst

\footnotetext{
${ }^{56}$ Ibid., 12 August 1868, p. 449.

${ }^{57}$ Ibid., Vol. 3, 4 September 1868, p. 184. Vogel's motion emerged as The Immigration Act 1868, No. 42.

${ }^{58}$ Ibid., 16 September 1868, p. 300.
} 
the leaders of the Opposition bloc, labelled the Constitutional Party by correspondents, although editorial reaction to their assuming the Ministry was mixed. ${ }^{59}$ But Stafford would not admit defeat and he revealed his true feelings at the end of the Session when he declared 'I shall...urge our friends to take every possible opportunity of pointing out how miserably insufficient the present provincial system is to meet the wants of the people, and of demonstrating how, whatever little efficiency it once possessed has, as a rule, died out. $^{\text {, }}$

Then, to underline his importance in Otago and his indifference to Wellington, Macandrew abandoned the Assembly for its last month to head south and open the substantial and expensive Balclutha Bridge across the Molyneux River on 7 October $1868 .^{61}$

\section{VOGEL AND THE PROVINCES 1869-1874}

Dissatisfaction with Stafford's administration brought change and on 9 June 1869 the General Assembly supported Fox's want-of-confidence motion on Stafford's management of the war with Maori. ${ }^{62}$ Fox's anti-centralist party, with Vogel now Colonial Treasurer, had an opportunity to revitalise the provincial system but they were challenged on 12 July by Stafford-supporter Edward Stevens, the Member for Selwyn, who resurrected an 1868 Assembly motion that no more subdivisions of the Colony funded from the consolidated revenue should be created. Stevens moved that any further constitutional changes should incorporate eight principles which included curbing taxation, allocating loan repayments from provincial land funds and increasing colonisation immediately. ${ }^{63}$ His most radical principle was his third, 'that Provincial Government should cease to exist, and a system of local government be established throughout the Colony,' with a devolution of 'full powers for management of local affairs' and funding to the new organisations. He considered that the piecemeal creation of counties was creating weak provinces; that all legislation could be done by the General Assembly, saving 'no less than $£ 10,400$ a year which was spent upon provincial legislation’ and taxes could be reduced - such changes "would unite the colony in a strong nationality. ${ }^{64}$ In a debate

\footnotetext{
${ }^{59}$ Colonist, 28 August 1868. Membership of the Constitutional Party was 29: Auckland 6; Wellington 6; Nelson 3; Canterbury 6; Otago/Southland 8.

${ }^{60}$ NZPD, Vol. 4, 16 October 1868, pp. 358-9.

${ }^{61}$ WI, 19 September 1868. TT, 10 October 1868.

${ }^{62}$ Colonist, 25 June 1869.

${ }^{63}$ Ibid., 16 July 1869.

${ }^{64}$ WI, 15 July 1869.
} 
extending over several days, most speakers, including members of Fox's "Provincial" Ministry, agreed that a change was necessary but the majority of them were unsure about what they wanted. ${ }^{65}$ Agreement could not be reached and a cautious amendment accepted on 23 July postponed further change: it was agreed that in the present condition of the colony, it is inopportune to decide questions involving great Constitutional changes; that such should more properly be left for the consideration of the next Parliament. ${ }^{, 66}$

Otago benefited immediately from the change of government. Macandrew presented his Otago Settlements Bill which promoted settlement on the West Coast by selling land at a lower price than had been permitted by the Otago land regulations. This was passed with no discussion although the Legislative Council made two minor adjustments and it became law in record time. ${ }^{67}$ In August, Macandrew successfully shepherded the Otago Loan Bill through the House. It sought to overturn the ban on provincial borrowing with a request that Otago be permitted to raise a loan of $£ 50,000$ for ever more public works. In a debate that would have infuriated members from other provinces, Macandrew, at his insufferable best, catalogued Otago's assets-estimated revenue for $1869 £ 301,000$; value of unsold land $£ 3,100,000$; main roads and bridges $£ 1,120,000$; public buildings $£ 90,000$; school buildings $£ 50,000$; dredge $£ 10,000$; wharves and harbour $£ 187,000$; total debt $£ 650,000$ - and claimed 'he felt ashamed almost, at asking for a paltry loan of $£ 50,000$ '. Vogel was supportive, and, provided the loan was 'a strictly local one, raised by trustees, to be met out of pastoral revenue, the Government would make no objection.' Stafford, however, was opposed to the provinces competing in the money markets, 'depreciating each other's stock' while using their unreserved land as security. He suggested that larger loans at lower rates could be obtained if the Colony as a whole borrowed for a cohesive programme of public works. ${ }^{68}$ The Legislative Council concurred. They agreed with Dillon Bell that 'to mortgage the pastoral rents is tantamount to saying that there shall be no more legislation on the land question' and rejected Macandrew's Bill. ${ }^{69}$ Stafford had enunciated an important principle - the Colony would achieve more by acting in unity and his advice bore fruit within the year.

${ }^{65}$ ODT, 28 July 1869.

${ }^{66}$ Colonist, 3 August 1869.

${ }^{67}$ NZPD, Vol. 6, 22 July 1869, p. 73. The Otago Settlements Act 1869, No. 11, became law on 6 August 1869.

${ }^{68}$ Ibid., 17 August 1869, pp. 500-5, 18 August 1869, pp. 534-47.

${ }^{69} \mathrm{OW}, 11$ September 1869. 
Treasurer Vogel amazed the Assembly, and the electorate, on 28 June 1870 when he presented his Financial Statement: Estimated Receipts-£1,051,500; Estimated Expenditure — $£ 903,523$; capped by a bold proposal for the Colony, as a whole, to borrow $£ 6,000,000$ and to invest $£ 10,000,000$ over ten years in a North Island trunk road, Middle Island railways, goldfields' improvements, increased immigration and a North Island land bank. ${ }^{70}$ Reactions ranged from Reader Wood's outraged 'in all his experience, he had never heard of a scheme so wild, so unpractical, and so impracticable ${ }^{71}$ to Macandrew's enthusiastic 'I think we should be sacrificing the substance for the shadow were we to object to that policy as a whole on merely what I would call minor considerations; for, after all, provincial considerations are minor considerations....Sir, as an old colonist...I see in these proposals the realization of a day dream, of aspirations I have cherished for the last twenty years. ${ }^{, 72}$ Macandrew and Vogel were back in harness again and Macandrew seems to have forgotten his demand for fiscal caution on the part of the government.

Embedded in the Financial Statement was Vogel's philosophy on governance, and its teeth. In his pursuit of members' support and seeking constituency backing in the election scheduled for January 1871, he was careful to avoid extreme positions, stating 'I have already said it is desirable to avoid as much as possible mixing up organic political changes with the great colonizing question...violent political changes are much to be deprecated, and in the present case they would not answer the end in view.' He expounded the need to progress colonization which would best be done by local institutions - railways might be commenced under either Provincial or General Government auspices and might eventually, if necessary, be consolidated into one entity. ${ }^{73}$ Vogel's Statement formed the basis of three Acts passed on 12 and 13 September to borrow and allocate funds for the various projects while he kept control firmly in the hands of Central Government. ${ }^{74}$

Dillon Bell (Sir) 1821-98, related to Edward Gibbon Wakefield, employed by N.Z. Co. London 1839 then N.Z. 1843-51, Commissioner of Crown Lands Wellington 1851-55, pastoralist, Member Wellington PC 1853-56, Wellington Executive Council 1854, Member OPC 1865-67, 1869-70, 1871-73, MHR 1855-56, 1859-75, Member of Executive Council (Fitzgerald Ministry) 1854, Colonial Treasurer (Sewell Ministry) 1856, Colonial Treasurer, Minister of Native Affairs and Customs (Domett Ministry) 1862-63, Member of Executive Council (Fox Ministry) 1869-71, Speaker HR. 1871-75, MLC 1854-56, 1877-80, Agent-General 1880-91, KB 1873, KCMG 1881, CB 1886.

${ }^{70}$ Dalziel, p. 107 . New Zealand's debt at that time was already $£ 8$ million.

${ }^{71}$ NZPD, Vol. 7, 28 June 1870, p. 115.

${ }^{72}$ Ibid., 12 July 1870 , p. 349.

73 Ibid., 28 June 1870, p. 104.

${ }^{74}$ Immigration and Public Works Act 1870, No. 77, the Immigration and Public Works Loan Act 1870, No. 80 and the Payments to Provinces Act 1870, No. 82. The provinces were to be charged interest on the cost of their projects although they were allowed to exchange land for the loans. 
Otago Provincial Councillors were unimpressed by such largesse because of the restrictions placed on their autonomy and in July 1870, William Reynolds responded with his predictable resolutions-divide the Colony into two provinces, restrict the Colonial Government to three departments with responsibility for Colonial debt; make all revenue provincial, with a capitation grant to the Colonial Government and for interest payments. ${ }^{75}$ But Vogel, having launched his scheme and with a poor opinion of the country's capacity for change, reiterated that 'it would be almost impossible to carry out any plan, upon a comprehensive scale, for the permanent settlement of the Colony, if at the same time the minds of the colonists were distracted by the consideration of large political changes. ${ }^{76} \mathrm{He}$, shrewdly, did not dismiss Reynold's resolutions but declared that if his financial scheme 'shall show such a thing is necessary, there is nothing to prevent our adopting, at some future time, some such proposals as those. ${ }^{77}$

Pragmatic Macandrew read the omens, and in an unexpected change of attitude, presented a bill to validate an Otago Ordinance to consolidate its one hundred and ten Road Boards into thirty-five and to permit the Boards to make bylaws and to charge rates. He could see the provinces might be replaced by smaller bodies and this was his opportunity to shape those bodies, knowing that the Roads Boards would be entitled to a share of the new funding of $£ 50,000$ allocated to them in the Financial Statement. ${ }^{78}$ When he presented his large bill of over two hundred clauses, he claimed it had been approved by his Provincial Council and, over-confident, he did not intend to debate it if the House would not 'validate it in its entirety.' This was provocation indeed. Macandrew was mocked for pursuing a course which 'would do away with Provincial institutions' and the Legislative Council rejected the bill, in part, because of his brow-beating. ${ }^{79}$ It was a typical demonstration of his parliamentary tactics - his blithe self-confidence, his use of clever parliamentary procedure, his preparedness to adapt to change and to exploit unexpected opportunities but at times, he was also an extremely tactless performer. Unfazed and playing to Otago voters, his next move, on 29 August, had a predictable outcome. He requested permission to raise a loan of $£ 650,000$ for Otago public works projects and

\footnotetext{
${ }^{75}$ NZPD, Vol. 7, 6 July 1870, p. 215.

${ }^{76}$ Ibid., p. 221.

${ }^{77}$ Ibid., Vol. 12, 7 August 1872, p. 337. This is Reynold's report of a comment made by Vogel in this 1870 debate.

${ }^{78}$ Ibid., Vol. 7, 28 June 1870, p. 100.

${ }^{79}$ Ibid., 20 July 1870, p. 546; Vol. 8, 3 August 1870, p. 271 \& 10 August 1870, p. 431; Vol. 9, 24 August 1870 , p. 252.
} 
received short shrift from Vogel who pointed out it was inconsistent with the Government's policy that the provinces could not borrow independently. ${ }^{80}$

The composition of the House was considerably altered when it resumed after Vogel's return from overseas in August 1871. It had thirty-nine new members out of seventy-eight, and Fox's support was reduced. ${ }^{81}$ Macandrew, given his suspicion of the provinces' probable demise, and needing to mollify his increasingly reactionary Provincial Council, was quick to present an Otago motion to the General Assembly. ${ }^{82} \mathrm{He}$ was impatient for a resolution of the uncertainties surrounding the future of the provinces, and eager to gain provincial control of the new colonial loan. He claimed his longevity as a Member entitled him to raise an issue which was rightly the Ministry's business and on 14 September he presented thirteen resolutions for Constitutional Change: he called for an amalgamation of the Middle Island provinces and county into one Provincial Legislature, overseen by a Lieutenant-Governor, financially independent, administering the Waste Lands uniformly and responsible for its share of the funds arising from The Immigration and Public Works Act 1870. He deliberately excluded the North Island from his scheme, claiming it was not ready for 'provincial fusion' but for the Middle Island, it would bring uniformity of laws, economy of administration and local knowledge to the inevitable promulgation of counties.

The Auckland Morning News suggested that Macandrew was doing the Ministry's work. They did not agree with his proposals but they detected another agenda. 'It is a difficult game the Superintendent is playing; but if he succeeds, he will have achieved a double triumph. He will have humiliated the Otago country members, who hate him most cordially, and compel them to become joints in his tail; and what is of far greater consequence to the country, he will have postponed any solid reform for a twelvemonth, and rendered the tenure of office by the Government more likely than it otherwise would be. ${ }^{83} \mathrm{~A}$ Wellington paper saw uncontrolled Macandrew ambition in the resolutions and warned of a 'Lieutenant-Governor Macandrew at the helm of such a very composite confederation, Mr. Reynolds vice, and the body of very disinterested Otago members as whippers-in' and hoped that if the resolutions came to a division that 'the good sense of the House will administer a lesson that a gentleman possessed of even his pachydermatous

\footnotetext{
${ }^{80}$ Ibid., Vol. 9, 29 August 1870, p. 381.

${ }^{81}$ EP, 27 February 1871 and WI, 4 February 1871.

${ }^{82}$ NZPD, Vol. 10, 14 September 1871, pp. 421-25.

${ }^{83}$ ODT, 18 September, 1871.
} 
qualities must inevitably wince under. ${ }^{84}$ Neutral opinion of Macandrew was always conspicuous by its absence and suspicion of his motives never fully disappeared, all made worse by his frequently polarising behaviour.

Former Member Edward Stevens described Macandrew's resolutions as 'a perfectly insane and impossible [programme] as it ignores, whilst proposing to revolutionize the constitution of the colony, any of the governmental requirements or at least many most important ones, of one half of the country. ${ }^{85} \mathrm{He}$ included a detailed list of problems which would arise if the resolutions were accepted which highlighted Macandrew's penchant for grand plans and his lack of attention to detail, and added 'I can hardly think it possible that Ministers can have consented to entertain such proposals, nor do I think that Vogel, although I do not consider him as having even the germ of a statesman in him, could be so perfectly stupid as to waste public time in thinking about the resolutions' a comment which suggests the new Opposition viewed Macandrew and Vogel as collaborators and Macandrew's resolutions were being treated seriously by the Assembly. Fox, while dismissing the resolutions as incompatible with Government policy, noted the difficulty experienced in choosing the seat of a Middle Island General Executive. It is unclear whether Macandrew's answer was irony or aggrandizement when he replied 'that may very well be left to the Provincial Council, and probably Cromwell would be a very good site. ${ }^{86}$

Treasurer Vogel's contribution to the constitutional debate was his Provincial Governments Bill which was given its second reading on 12 October. It was designed to reduce 'the dimensions of the machinery and the expenditure of the provincial system...the whole scope of this measure will be to make the provincial body much more intimately related to the Superintendent' but in appearing to reduce provincial powers it was seen as the thin end of the abolition wedge ${ }^{87} \mathrm{He}$ proposed that Superintendents should become ex officio members of their Councils; that the same electoral districts should be used for both Houses, thus reducing the number of Council members, and that Councils could be dissolved without dismissing Superintendents, and vice versa. Vogel's nibbling technique had reduced the role of the provincial governments in the forthcoming immigration and railways projects and he had reduced grants to the provinces but in the

\footnotetext{
${ }^{84}$ EP, 24 August 1871.

${ }^{85}$ Letters: Stevens/Stafford, 27 \& 31 August 1871, ATL, MS-2050.

${ }^{86}$ NZPD, Vol. 10, 14 September 1871, p. 427

${ }^{87}$ Ibid., Vol. 11, 12 October 1871, p. 280.
} 
face of strong opposition, he withdrew his bill. Dalziel proposes that Vogel was 'slowly but surely strangling the provincial governments' but does not see evidence of a cohesive plan. ${ }^{88}$ It is likely Vogel was now affected by the complexity of operating two levels of government and the removal of one layer looked highly attractive: he committed Fox's Government to deal comprehensively with constitutional matters in the following year and to fully define Provincial Council functions.

The separationists were unprepared to let the matter lie. Not content with 'the puerile attempt of the government with regard to constitutional reform' and in the absence of any attempt to discuss the matter except for Macandrew's resolutions, another Otago dissident, William Murray, Member for Bruce, presented his resolutions which demonstrated further ingenuity with yet another variation of local government organisation. ${ }^{89}$ He proposed that the country be divided into counties which would be grouped into two North Island provinces and three Middle Island ones 'for purposes of revenue and co-operation.' He was promptly ignored! On 10 November, William Steward, Member for Waitaki, took the opposite approach in an attempt to pin down the Government. He requested the Ministry prepare a bill during the recess 'for the simplification of the form of provincial institutions by the withdrawal of their legislative powers, or for the entire abolition of such institutions at a fixed date, and the substitution therefor of a system of local administration under county and district Boards. ${ }^{90} \mathrm{He}$ too was ignored. The session ended with Vogel's promise of 'a new Constitution Act' although there was a mounting suspicion that his grand plan for New Zealand's economic salvation had run into difficulties.

Vogel's promise was slow to emerge. Over a year later, his suggestion of a need for centralised management of the Colony drew a frustrated group of 'Superintendents and their tail' into a caucus which was seen by an observer as one that 'may, and probably will, raise the party of opposition into one of active obstructiveness to the real business of the session, and by the banding together of dangerous and disaffected adherents under the leadership of a Fitzherbert or a Macandrew, retard the beneficial working of a policy of colonisation.' ${ }^{91}$ Their pursuit of provincial control of public works and immigration ensured a tumultuous session of the Assembly in 1872 which endured three changes of

\footnotetext{
${ }^{88}$ Dalziel, p. 125.

${ }^{89}$ NZPD, Vol. 11, 25 October 1871, p. 525.

${ }^{90}$ Ibid., 10 November 1871, p. 980.

${ }^{91}$ Auckland Herald quoted in the Star, 14 August 1872.
} 
Ministry-Fox defeated, Stafford reinstated for his fourth term as Premier for just thirtytwo days, then George Waterhouse installed as the leader of a ministry in which Vogel was the real power-but little progress was made on public works and immigration.

Constitutional change was a recurring theme in the 1872 session: Vogel denied that his Government had overlooked its promise 'to deal comprehensively with the whole subject of provincial institutions and to define the functions of Provincial Councils' then said it was now not necessary. ${ }^{92}$ The Ministry, he said 'should interfere as little as possible with the existing institutions of the Colony' because Central and Provincial Governments had worked much more harmoniously during the year so there was no pressure on Government to force changes and 'I think it quite possible that we shall see-perhaps after the lapse of some considerable time - the establishment of a single Province in each Island, exercising larger provincial legislative powers than those which at present exist.'

Then Nelson Superintendent Oswald Curtis moved that 'hasty changes in the boundaries of Provinces, and especially the establishment of new Provinces, tend to uncertainty and confusion in government, and to needless increase in departmental expenditure' and he wanted to see a 'definite and permanent scheme applicable to the whole Colony. ${ }^{93}$ Macandrew retorted that that motion was 'a self-evident proposition which could not be gainsaid' and if it had been acted upon years ago would have saved hundreds of thousands of pounds. ${ }^{94}$ Reynolds now offered his 'definite and permanent scheme' in the form of fifteen resolutions which called for each Island to become a separate Province and for the establishment a federal government for New Zealand, and in a move reminiscent of his brother-in-law, suggested that Akaroa be the Seat of Government for the Middle Island. ${ }^{95}$ He reminded the House that Fox had promoted a similar scheme in 1863 and Vogel had done likewise in 1870. While Fox prevaricated, Stafford sprang to Reynold's defence and vigorously attacked Fox, a foretaste of the wantof-confidence debate which began two weeks later and ousted the Fox Ministry on 5 September 1872 .

Stafford alleged that Fox's administration of the public works and immigration policy had been unsatisfactory, that Ministers were too often away from Wellington which led to insufficient consultation, inefficient management and extra cost, and that 'the

\footnotetext{
${ }^{92}$ NZPD, Vol. 12, 24 July 1872, p. 68-70.

${ }^{93}$ Ibid., 7 August 1872, pp. 326-28.

${ }^{94}$ Ibid., p. 330.

${ }^{95}$ Ibid., p. 334.
} 
colonial Government should retain full responsibility for the proper conduct of all works authorised and the sole control of all sums voted by Parliament' but where possible, use existing provincial machinery to do the job. ${ }^{96}$ In this debate, Macandrew supported Fox. In his speech, Macandrew was blunt — with such a new policy and lacking experience 'the Colonial Legislature has made a grand blunder in undertaking the practical administration of the public works and immigration policy at all, believing as I do that it would have been far better administered by the respective local Legislatures. ${ }^{97} \mathrm{He}$ argued that Ministers needed to travel around the country to keep informed then he praised Vogel, declaring that nobody could have negotiated a shipping contract with the Victorian Government better than the Colonial Treasurer. Although disagreeing about the place and powers of the provinces, up to this time Macandrew and Vogel remained close colleagues. The House divided closely and Fox resigned. ${ }^{98}$

Stafford's Ministry lasted less than a month. On 4 October 1872, following a snap want-of-confidence debate won by two votes, Vogel orchestrated the appointment of an experienced newcomer, Legislative Councillor George Waterhouse-a former Chief Secretary of South Australia-who 'met Parliament on 11 October in the unique position of a Premier without portfolio, without salary and without a seat in the popular chamber. ${ }^{99}$

At this juncture, Macandrew might have been expected to be offered a Ministerial appointment. Vogel controlled the ministry and Macandrew was described now as

a man in whom the possession of no real genius, no startling attainments or exceptionally superior qualities of mind and intellect, is counterbalanced by an unusually liberal allowance of sound and solid common sense, perhaps the most useful, if not the most brilliant of all possessions. A stolid manner and a constant exercise of this strong sense and perseverance, with the canniness and craftiness of the true Scot, have enabled him to work his way on from a comparatively insignificant position to a well-won seat in the councils of the Province, to his present status in its respect, and even higher than that, to a seat in the House of Representatives. ${ }^{100}$

Macandrew was not a charismatic parliamentarian, despite his popularity in Otago, but his political career had been long and varied, his party was in the ascendant and he was an

\footnotetext{
${ }^{96}$ Ibid., Vol. 13, 5 September 1872, p. 155.

${ }^{97}$ Ibid., Vol. 12, 27 August 1872, p. 673.

${ }^{98}$ Ibid., Vol. 13, 5 September 1872, p. 156.

${ }^{99}$ George Marsden Waterhouse, 1824-1906, Member South Australia Legislative Council 1851-54, 1857, 1860-63, Chief Secretary South Australia 1861-63; Wairarapa pastoralist, MLC 1870-90, Member without portfolio (Fox Ministry) 1871, Premier 1872-73, Speaker LC 1887. Waterhouse is the only Premier who sat in the LC.

${ }^{100}$ ODT, 31 August 1874.
} 
intimate of Vogel. He was energetic in Parliament: the disconsolate Henry Sewell, when displaced after a month as Stafford's Colonial Secretary, reported that 'Macandrew may be seen at all times and all places_-passant and fumant. ${ }^{101} \mathrm{He}$ was a powerbroker par excellence-described as 'at no time an aspirant to office as a Colonial Minister, he has done more than almost any man to make and destroy Ministries. ${ }^{102}$ Holding two leadership roles was acceptable-John Ormond was Superintendent of Hawkes Bay when appointed as Minister of Public Works. However, Otago had been accommodated by the appointment of John Bathgate and William Reynolds as ministers and Macandrew was not called. Perhaps his allegiance to Otago and his family made him refuse an offer: his eight children now ranged in age from three to 23 years old. Perhaps he felt he could not give the two jobs his full attention. Perhaps he felt that his record would be held against him. Whatever the reasons, he did not appear to carry a grudge and he entertained Vogel in Dunedin during the summer recess of $1872-73 .{ }^{103}$ Nor did Vogel use the occasion of his appointment in April 1873 as Premier and his subsequent Cabinet reshuffle to appoint Macandrew.

\section{ENDGAME 1874-1876}

Macandrew and Vogel parted company as their positions on the role of government diverged: Vogel's responsibility for the wellbeing of the whole colony led him to back a central government while Macandrew grew increasingly rabid in his defence of the provinces. Then, with the introduction of his New Zealand Forests Bill on 14 July 1874, the Premier commenced the concatenation which brought down the provincial structure. It is likely that he had been influenced during his 1873 summer visit to the south by Macandrew's descriptions of Otago's successful forestry activities. Vogel's bill proposed to establish state forests by requisitioning $3 \%$ of the land in each province in return for suspending their repayment of loans for building railways. When he opposed the bill on 4 August, Macandrew agreed about the importance of the conservation of forests but he objected to Vogel's proposed means: 'I cannot see what necessity there is for removing the control from the hands of those who have hitherto been administering these forests...the authorities on the spot are far more likely to preserve timber from waste than any Ministers sitting here in Wellington. ${ }^{104} \mathrm{He}$ saw no need for the creation of State forests: forests

\footnotetext{
${ }^{101}$ Letter: Henry Sewell/Stafford, 31 October 1872, ATL, MS-2050.

102 Daily Southern Cross, 5 May 1875.

${ }^{103}$ Dalziel, p. 155.

${ }^{104}$ NZPD, Vol. 16, 4 August 1874, p. 401.
} 
should be left to private enterprise, and he argued that 'if the State goes in for growing timber, I do not see why it should not go in for growing flax, corn, or any other commodity...there is a very great danger of the State usurping individual functions.' This summarised his view on State intervention: Macandrew saw the State's role as limited to guidance and the financing of major projects which private capital was unable to afford.

In response, Vogel noted that many of the speeches opposing the Forests Bill had 'resolved themselves into questions not affecting the bill, or its objects, but affecting other matters relating to the question of provincialism' and agreed with Macandrew that the Government could leave the forests to provincial management if it only had to deal with one or two provinces. ${ }^{105} \mathrm{He}$ continued 'but we have to do with the whole colony; and this Bill is essentially one which is proposed in the interests of the colony as a whole.' Vogel then upstaged Macandrew by quoting from a report written by an Otago Provincial Government forester that stated 'I am of opinion that it is of the utmost importance to the community to have the existing forests protected from the reckless extravagance which is so prevalent in this province' but Vogel denied that the State would take over working forests. ${ }^{106}$ William Fitzherbert had riled Vogel particularly in refusing to release any Wellington land and it now appeared that the Bill's Committee stages might considerably weaken it.

The responses to his bill unleashed Vogel's frustrations with the Opposition and with the continuing demands of the impoverished North Island provinces. He now declared the time had come for the Central Government to exercise responsibility and power over public works and immigration. On 13 August he conceded that his actions would likely end political alliances which had lasted for years and would 'alienate from me support which has been most generously and ungrudgingly given in the past' and presented to the House three resolutions: 'that the provincial form of government in the North Island should be abolished; and that in the measure giving effect to the same there should also be included a provision declaring Wellington to be the seat of government of the Colony, and for continuing the localization of the land revenue with what is known as the compact of 1856.' The Government would decide over the recess on the best model to replace the provinces. $^{107}$

\footnotetext{
${ }^{105}$ Ibid., pp. 415-26.

106 Ibid., p. 417.

${ }^{107}$ Ibid., 13 August 1874, p. 581.
} 
Reid and Macandrew buried the hatchet and united to lead the Otago opposition to Vogel's resolutions and on 18 August 1874 Macandrew spoke at length-his main concern was the 'spoliation of the Middle Island land revenue' to support the North Island while he felt the Government was unwise to 'nip in the bud that dawning spirit of self-reliance which is at the present moment coming over the North Island. ${ }^{108}$ It was in this debate that he made his memorable assertion: 'Sir, the Colonial Government is the upas tree beneath whose pestiferous shade all life dies, and death lives.' Given his previous public statements about the inevitable passage of the provinces, he cannot have been surprised by the turn of events. It is possible that he had expected all the provinces to be abolished and was surprised that Vogel had chosen only to eliminate the northern ones. That Vogel won the division on his resolutions by forty-one votes to sixteen indicated that he had read the country correctly, evidenced by a typical comment: 'though the storm has apparently gathered rapidly and broken on us suddenly, the elements of it have in fact been gathering in the political atmosphere for years. ${ }^{109}$ The die-hard provincialists in the House-Vogel claimed they were eleven Superintendents, Members of Provincial Executives, or Speakers of Provincial Councils - could be dealt with at leisure. In Committee he denied he had changed his mind suddenly and reminded listeners of his 1870 criticisms of the provinces. He then proceeded to skewer his critics' inconsistencies. In response to Macandrew's demand for consultation, he pointed out that in 1871 Macandrew had proposed to destroy all the provinces of the Middle Island without going to the country. ${ }^{110}$ This debate marked the end of Vogel and Macandrew's alliance. Gossip suggesting that Stafford might join Vogel's Cabinet was the final straw for Macandrew and he consistently voted with the Opposition from then on. ${ }^{111}$

When Parliament opened on 20 July 1875 Macandrew's suspicions were confirmed. The Governor announced that the measures for the abolition of the provinces in the North Island had been prepared and members would be asked to decide whether the abolition 'be so extended as to include the whole of the provinces. ${ }^{112}$ The Ministry, with Premier Daniel Pollen now replacing Vogel who was making an official visit to London, had decided to be done with half measures and abolish them all. When the Abolition of the Provinces Bill was introduced by Colonial Treasurer Harry Atkinson ten days later,

\footnotetext{
${ }^{108}$ Ibid., 18 August 1874, p. 699.

${ }^{109}$ ODT, 8 August 1874.

${ }^{110}$ NZPD, Vol. 16, 24 August 1874, pp. 888-890.

${ }^{111}$ ODT, 29 August 1874.

${ }^{112}$ NZPD, Vol. 17, 20 July 1875, The Governor's Speech, p. 2.
} 
Macandrew was one of a 'small but compact phalanx' of Superintendents—skilled parliamentarians - who opposed the bill. ${ }^{113}$ Sir George Grey, outraged by the prospect of abolition, was now Superintendent of Auckland and Member for Auckland City West, elected in March 1875 to bring the fight to the Government; William Fitzherbert was Superintendent of Wellington and William Rolleston was Superintendent of Canterbury. Donald Reid supported Macandrew and they voted together on all divisions but they were completely routed when the Bill's First Reading was affirmed by fifty-two votes to seventeen, a clear message that the Assembly, and the country, were ready, if not impatient for change. ${ }^{114}$

This debate was Macandrew's final opportunity to sway his Parliamentary colleagues and he failed. He knew that abolition would be approved and he worked hard to influence the final shape of the Act. Macandrew was at his eloquent best when he spoke on 24 August 1875, during the Second Reading. Although the arguments were familiar, they were delivered with passion, if in a somewhat jumbled order. ${ }^{115} \mathrm{He}$ began by denying that the Superintendents were concerned about losing their jobs, then he agreed it was time to modify the existing system of government in the colony because of its expense but it was 'this Legislature [which] ought to commence to reduce the colonial establishment' and stick to its business as laid down by the Constitution. In his twenty-one years in the House he had seen 'an usurpation of provincial functions' and Provincial Councils, 'instead of being encouraged by this central Legislature... have as a rule been thwarted and have had every obstacle placed in their way, when endeavouring to develop the resources of this colony.' He saw little saving in delegating functions to Road Boards and he considered that Assembly members would be incompetent to legislate for provincial matters. He could not see a great demand for change: 'We are told that the people from one end of the colony to the other are demanding that their local administration shall be handed over to the Central Government; but I ask, where is the evidence of this? Where are the petitions?' He was convinced that Otago would lose its land reserves, especially its educational reserves and he had no sympathy with the complaining goldminers who claimed they were treated unfairly by the Provincial Council: 'In common with all the outlying districts, the people on the gold fields will find that if Provincialism has chastised them with whips, Centralism will chastise them with scorpions.' He scorned the proposed centralising of the police as an

\footnotetext{
${ }^{113}$ NOT, 31 August 1875.

${ }_{114}^{114}$ NZPD, Vol. 17, 27 August 1875, p. 705.

${ }^{115}$ Ibid., 24 August 1875, pp. 522-527.
} 
expensive mistake; he claimed that Atkinson's experience in diminutive Taranaki left him unaware of how busy the Otago Council was and asked how the Assembly would deal with Otago's fifty-nine Bills of local interest. He considered that Auckland's pending bankruptcy was no reason for abolition, rather 'it affords the very strongest argument and reason why Auckland should be turned adrift to manage its own affairs out of its own resources.'

Macandrew wanted 'a return to the spirit and intention of the Constitution-that Constitution which provides that each province shall manage its own affairs, and shall provide for its own peace, order, and good government...the practical effect of this Bill would be, not to make New Zealand a great and united colony, but to place it under the worst of despotisms - namely, the despotism of a Government apparently but not really responsible to the people.' He read out resolutions passed by the Otago Provincial Council and he presented more from a public meeting in Balclutha, deploring the changes and seeking consultation. He ended by accusing the Ministry of going too fast: 'my belief is that you do not believe that the country is with you, otherwise there would be no such haste' and it was not constitutional change the Government wanted, but financial reform and the reduction of taxation. His was a bravura performance but in two months of heroic speeches, it was not exceptional.

The Second Reading took three weeks and was delayed by the Opposition's obstructive tactics. Atkinson realised that he might not achieve his goal to pass the Bill that Session so to speed its progress he compromised on the Act's implementation date. ${ }^{116}$ This was agreed would be 'the day next after the last day of the first Session of the next or sixth Parliament of New Zealand,' at least a year hence and a small victory for his opponents. ${ }^{117}$ The Ministry accepted more changes during the Committee stage which ran through September, with the Bill finally becoming law on 12 October $1875 .{ }^{118}$ It repealed Section Two of the Constitution Act, replaced the provinces with Provincial Districts and forbade Provincial Councils to meet in the interval - the remainder of the Act specified procedures for the makeover.

Macandrew was energetic in attacking the Bill and moved several amendments, scoring a minor victory when he persuaded the Government to add museums to the list of

\footnotetext{
${ }^{116}$ Morrell, The Provincial System, p. 257; NZPD, Vol. 18, 1 September 1875, p. 166. Second Reading, 37 in favour, 15 opposed.

${ }^{117}$ Section 28.

${ }^{118}$ An Act to provide for the Abolition of Provinces 1875, No. 21.
} 
institutions to be funded from the Consolidated Fund. ${ }^{119}$ His amendment to establish an Otago Board of Works to undertake public works was lost when that responsibility was given to the local governing bodies which were yet to be defined but his amendment to establish an Otago Education Board to manage educational matters including the education land reserves became the country's model. ${ }^{120} \mathrm{He}$ fired his last salvo on 29 September when he prognosticated bleakly 'I shall simply content myself by denouncing the whole proceeding as unreasonable, tyrannical, and utterly unworthy of any representative assembly. Unless I very greatly mistake the spirit of my fellow-colonists throughout New Zealand, this Act will evoke a spirit of resentment which, I believe, will result in this Assembly being crushed into the dust. I feel very strongly upon the subject, and I can hardly trust myself to say what I should like to say, in case I should indulge in unparliamentary language., 121

The Third Reading passed by forty votes to twenty-one-the provincialists could usually muster about seventeen members and Macandrew had only persuaded four more to change sides on the Bill-while the large majority in favour indicates that he was out of touch with his colleagues if not with a large proportion of the public. ${ }^{122}$ Perhaps he was blinded by the continuing Otago support he had received: he returned there on 27 October, a hero accompanied by the Superintendents of Auckland, Wellington and Canterbury, to launch his election campaign and to continue the fight against abolition. He continued to make regular attacks to prevent the ratification of the Act until the dissolution of the provinces on 1 January 1877.

He distributed a privately printed pamphlet in November, an Address to the People of Otago in which he took more than 32,000 words to put his usual arguments. ${ }^{123}$ But not all his listeners were impressed with him and an Otago detractor voiced the opinion of many New Zealanders that 'Mr. Macandrew is intensely Provincial in all his ideas, and appears to be utterly incapable of taking a broad Colonial view of the question before him. If there were a James Macandrew in every one of the nine Provinces, and each had his own way, New Zealand, instead of being a prosperous colony, would inevitably become a land whose people would be divided against themselves, cursed with petty jealousies, and

\footnotetext{
${ }^{119}$ NZPD, Vol. 18, 23 September 1875, p. 560.

${ }^{120}$ Ibid., 22 September 1875, p. 529.

${ }^{121}$ Ibid., Vol. 19, 29 September 1875, p. 74

${ }^{122}$ Ibid., p. 75.

${ }^{123}$ James Macandrew, Address to the People of Otago, Dunedin, Mills, Dick and Co., 1875.
} 
growing up in narrow-mindedness and selfishness' but this critic did not speak for most Otago voters. ${ }^{124}$

Otago's voters returned a platform of anti-Abolitionists in the General Election held between December 1875 and January 1876 when Macandrew withdrew from Port Chalmers and stood successfully for the Dunedin City seat which also returned Larnach and Stout. This was revenge on his brother-in-law William Reynolds, a sitting member for Dunedin City who had been a separationist but had recently become a Vogel Ministerironically, Reynolds was then returned for Port Chalmers. The new House was evenly balanced on the abolition issue, the Provinces' replacements were yet to be defined and the provincialists did not go quietly into the night. They mounted a vigorous campaign, in the newspapers and in the House, to prevent the Abolition Act from being ratified. ${ }^{125}$ In the process, they generated a great deal of hostility from most of New Zealand but were strongly supported in Auckland and Otago.

When he returned to New Zealand on 10 February 1876 Vogel resumed the Premiership and reinvigorated the abolition campaign by despatching three Commissioners to the Provinces to collect information for the provision of government services after the changeover. Macandrew did not accept that the decision was irrevocable as he considered Vogel's action premature. In a well-publicised exchange of letters with Vogel, he wrote 'it will be time enough to take such action after the parliament has determined as to what is to be the specific form of Government for the future' and he refused to assist the Commissioners. ${ }^{126}$ The letters reviewed the various arguments and although icily polite, did become personal, highlighting the breakdown in their relationship. Macandrew wrote: 'were I to trace the cause of our difficulties in dealing with our waste lands, I should have to attribute them chiefly to the action taken by yourself in granting a renewal of so many pastoral leases in 1866-7. ${ }^{, 127}$ Vogel's reply checkmated Macandrew. 'As you have twice referred to me personally, I may be allowed to say that I continued to aid the Provinces, and to believe they might be enabled to survive, long after that belief was dead in the minds of some of the most acute men in New Zealand. No Province has, in my opinion, more contributed to make Abolition necessary than has Otago-for it has refused to accept

\footnotetext{
${ }^{124} \mathrm{BH}, 19$ November 1875.

${ }^{125}$ Clutha Leader, 10 February 1876.

${ }^{126}$ AJHR, 1876, A-4. Letter: Macandrew/Vogel, 6 April 1876, p. 3. This correspondence was distributed in a private pamphlet in 1877 , printed by Mills, Dick \& Co., Dunedin.

${ }^{127}$ Ibid., Letter: Macandrew/Vogel, 22 April 1876, p. 8.
} 
any limit to its desire to expend money. ${ }^{128}$ The publication of this correspondence allowed the supporters of each side to keep score. Vogel was considered to have come off second best - and kept informed the members of the General Assembly which met on 15 July 1876 for the final round of implementing abolition, approving the new local government bodies. $^{129}$

On 3 August Grey tested the Ministry's commitment to abolition by moving an eight part resolution which called for a reconsideration of the colony's financial and constitutional affairs, the Colony to remain united, the establishment of a local government for each island, a redistribution of charges for the colonial debt which would be the responsibility of the Central Government, local government to totally control its own affairs and keep its own revenue, Auckland to be the seat of government in North Island, Christchurch to be the seat of government in the South Island, and the Central Government seat to remain in Wellington. ${ }^{130}$ This was yet another variation on the separationist resolutions that Reynolds had put in 1870 and 1872 and Macandrew and Murray had put in 1871 and triggered a two-week debate in which all the old arguments were rehearsed again.

Macandrew called for a simplification of the Colony's accounts 'so that a man of ordinary comprehension will be able to comprehend them. ${ }^{, 131}$ Having proposed that the country had wildly overspent, he offered three solutions: 'The first is: Add to the taxation of the country. The second is: Put your hands in the pockets of Canterbury and Otago. And the third is: Retrench on a scale suited to the requirements.' He saw the government attracted to the second choice as the third had never been on their agenda. He described New Zealand as an inversion of the parable of the Prodigal Son. 'Here, instead of the son wasting the substance of his father by riotous living, it is just the reverse. It is the father, in the shape of the Colonial Government, wasting the substance of the son; and, not content with wasting the substance of one son, he takes the whole nine, and wastes their substance.' It was time for the sons to take over the management of the estate and cut back the 'old gentleman's establishment.' He gave figures to show how much cheaper the Provincial Councils were than the General Assembly, especially as it would have to deal with the thousands of provincial ordinances on the books as well as colonial statutes. He extolled Otago yet again and claimed that there was no demand for counties there, as they could

\footnotetext{
${ }^{128}$ Ibid., Letter: Vogel/Macandrew, 3 May 1876, p. 12.

${ }^{129}$ McLintock, Otago, p. 608.

${ }^{130}$ NZPD, Vol. 21, 3 August 1876, p. 55.

${ }^{131}$ Ibid., 10 August 1876, pp. 225-228.
} 
have had them years ago and the outlying districts were content with the investment they had received, and noted the $£ 90,000$ interest paid annually by Otago on their public works loans.

His oration ended by damning 'grinding Centralism' and he demonstrated his erudition with a quote from Byron: 'All I can say is this, that if the Provincial Legislature of Otago, with the thousands of pounds it has had at its disposal as compared with the millions and millions which this Colonial legislature had had-if the Provincial Legislature of Otago had done no more to promote the intellectual, the moral, and the material interests of that province than this Colonial legislature has done to develop the resources of this colony, I should say, let the Legislature perish. I for one would not shed a tear on seeing it sink into the Ocean of Abolition, "with bubbling groan, Alike unknell'd, uncoffin'd, and unknown.", 132

Reaction to these sentiments depended on the listener's politics: one commented 'Mr. Macandrew's speech was the feature of the debate last night. It was intensely Provincial, Otago, and Macandrewite, but earnest and well-spoken. ${ }^{133}$ Another telegram simply stated 'Mr. Macandrew made a wretched speech.' ${ }^{134}$ Grey wanted to put the resolutions individually which was permitted only after a Speaker's ruling but all were lost by majorities of between fourteen and seventeen votes except the last, to retain Wellington as the seat of government. ${ }^{135}$

With a decisive majority and the provincialist party seemingly beaten, Vogel introduced his Counties Bill. There were to be sixty-three counties authorised to levy rates, with limited overdraft rights, and responsibility for county roads, public works and aid to charitable institutions. ${ }^{136}$ In response Macandrew claimed disparagingly that if this Bill is to be permissive, there is not one district throughout the colony which will avail itself of its provisions. ${ }^{, 137}$ He backed this up with resolutions passed by the South Otago Roads Board which included the comment that 'the Counties Bill introduced by the Government is cumbrous and utterly unworkable, and, if carried, will tend to throw the business of the whole province into a state of confusion.' Next he raised the spectre of rates 'I have no doubt whatever, when these rates come to be raised, when the 'shoe begins to pinch,' if

${ }^{132}$ Childe Harolde's Pilgrimage, Canto Four, Stanza 179.

${ }^{133}$ WCT, 12 August 1876.

${ }^{134}$ Bay of Plenty Times, 12 August 1876.

${ }^{135}$ NZPD, Vol. 21, 16 August 1876, pp. 377-379.

${ }^{136}$ The Counties Act 1876, No. 47.

${ }^{137}$ NZPD, Vol. 21, 22 August 1876, pp. 509-511. 
ever that does come, the people will then comprehend the force of the arguments which I am now adducing.' Then his demagogic side emerged 'I tell this House that in forcing abolition upon the Province of Otago, against its will, you know not what you do...you are exhibiting a recklessness and a tyranny repugnant to the spirit of free institutions, and altogether repugnant to the spirit of Englishness... inconsistent with the idea of this colony becoming a great and a united country.' Not only did he hint at secession by Otago, he finished with an attack on Vogel, in sadness rather than anger: 'Had an enemy done this, we could not have borne it, but it was one whom we honored and whom we trusted. Sir, his is the dagger that sends us to perdition! I do not believe that such a result was ever intended by him, but there is not the slightest doubt that he has been influenced by more astute men than himself.'

The London Agent-General's position had become vacant when Featherston died in June and Macandrew's reputation was sufficiently illustrious that he was named as a contender for the post, along with Vogel, Hall, Stafford, Fitzherbert, Donald McLean and Bell-Vogel was appointed. ${ }^{138}$ Perhaps this prominence, combined with reports of a series of well attended meetings throughout Otago which deplored the demise of the provinces, stimulated him to move yet another resolution in the House. ${ }^{139}$ The members' patience must have been sorely tried when he moved that the Governor be asked to dissolve the Otago Provincial Council and to call fresh elections, to give the voters a voice in the choice of a suitable self-government and he read a number of the resolutions passed at Otago meetings. With Vogel posted to London, the new Premier, Harry Atkinson, dealt brusquely with a Macandrew who 'seems unable to recognize the fact that his cause is the cause of the past' but the result of the division, thirty-seven votes to twenty-four, suggests Macandrew was not alone in his stance.

Macandrew dodged the last month of the Session by decamping to Dunedin to agitate further against the Abolition Act. He missed Grey's next stonewalling effort, The Provincial Abolition Permissive Bill which would allow each province to choose its own time of dissolution - it was voted out peremptorily. ${ }^{140}$ From Otago, Macandrew mounted his final acts of resistance, including mailing a petition to Queen Victoria, seeking Otago's secession from New Zealand, yet another example of his zealousness in the cause of provincialism.

\footnotetext{
${ }^{138}$ WCT, 15 August 1876.

${ }^{139}$ NZPD, Vol. 22, 19 September 1876, pp. 373-406.

${ }^{140}$ Ibid., Vol. 23, 26 October 1876, pp. 634-647.
} 
In the second period of his Parliamentary membership, Macandrew moved from spurned bankrupt to leader of a substantial opposition bloc. He was comfortable in the House and was an affable member who used its procedures to his advantage even though he lost his major battle. He was a kingmaker and was influential in dethroning Stafford and promoting Fox in 1869, worked to remove Stafford again in 1872 and replace him with Waterhouse, then supported Vogel's successful bid for Premier in 1873. Parliament gave him a national platform for his views and a position where he could answer the attacks he suffered on his home territory. Despite his authority in the House and the resistance of an active minority, the demise of provincial government was inevitable. The provinces were a necessity at their creation, when the settlements were separated by distance, time and culture but within twenty years, technological progress had brought them together. A unified country was possible, would be cheaper to govern and was desired by a growing majority of settlers who were prepared to have their taxes spent for the good of the entire colony. While the natural resources of Otago encouraged its residents to think that it could have continued to operate as an independent province, it is surprising that Macandrew chose to ignore the problems faced by the other provinces. His Christian beliefs did not extend to taking responsibility for the well-being of the entire country, he was not his brother's keeper. Ultimately, despite his regular and constructive contributions on a wide range of subjects in the House, Macandrew's earnest defence of the provinces as practical units of government saw him cast, unfairly, as a reactionary, a label that was to haunt him for the rest of his career in politics. 



\section{ChAPTER 7}

\section{Politician: Ministerial Career 1877-1879}

In 1871, Edward Stevens predicted the course of events which would drive Parliament for the next twenty years. ${ }^{1}$ He wrote: 'There will be a so called "party of progress" and a "prudent" party. Whilst there is money to spend the latter will be regarded as do-nothings and obstructive, when the money is spent the party of prudence will be invited to come in and restore solvency. Before they have accomplished this, they will be railed at as torpid and slow, and they will soon after be ejected to let the gamblers and thimble-riggers in again.' The boom and bust cycle was a consequence of the unstable economic conditions which afflicted New Zealand from the middle of the 1860s until the 1890s, as consecutive governments struggled to escape the inevitable depression. A parliamentarian had to have considerable faith in himself to believe he could influence the seemingly uncontrollable economy. Macandrew had such faith.

Macandrew's parliamentary career could have ended in January 1871 when he was rejected by his Clutha electorate but he was returned comfortably by the voters of Port Chalmers in February. ${ }^{2} \mathrm{He}$ was a popular Member in the House where, as one commentator contended, post-Abolition 'politics tended to degenerate into a sordid scramble for provincial gain. ${ }^{3}$ During the two-year tenure of George Grey's erratic Government of conservative provincialists and liberal reformers, Macandrew served as the Secretary for Crown Lands and Minister of Immigration for nine months and Minister of Public Works for eighteen months. ${ }^{4}$ Following Grey's defeat on 3 October $1879,{ }^{5}$ Macandrew was the only politician judged capable of attracting sufficient votes to defeat the Hall Ministry and was chosen to lead the opposition. ${ }^{6}$ But victory, and the premiership, was snatched from him when four of his supporters transferred their votes to John Hall. ${ }^{7}$

\footnotetext{
${ }^{1}$ Letter: Stevens/Stafford, 2 August 1871, ATL, MS-2050.

${ }^{2}$ Macandrew won $66 \%$ of the vote in 1871 ; he was the highest polling candidate of eight for the threemember City of Dunedin seat in 1875; he won 58\% of the vote for the Port Chalmers seat in 1879 and was returned unopposed by Port Chalmers electors in 1881 and 1884.

${ }^{3}$ Wilson, T.G., The Grey Government 1877-9, Auckland University College, History Series No. 5, Bulletin No. 45, 1954, p. 61.

${ }^{4}$ Scholefield, Parliamentary Record, p. 37. He held the Crown Lands and Immigration portfolios 15 October 1877-25 July 1878 and Public Works 28 March 1878-8 October 1879.

${ }^{5}$ NZPD, Vol. 32, 3 October 1879, p. 162.

${ }^{6}$ Wanganui Herald, 11 October 1879, 'Report of Liberal Party Caucus' held on 10 October 1879.

${ }^{7}$ NZPD, Vol. 32, 28 October 1879, p. 579. Macandrew let his intended want-of-confidence motion lapse.
} 
Macandrew led the opposition for three years, was recognised as 'Father of the House' in 1881 and served for two weeks in the Stout-Vogel Cabinet of August $1884 .^{8}$

This chapter examines Macandrew's performance as a Minister of the Crown when he could finally give free rein to his belief in deliverance through 'roads, population, bridges, capital. ${ }^{9}$ While he had advocated a high price for land in his early days in Otago, to control the flow of acceptable immigrants, now he wanted any deserving man to have access to land at the cheapest price and on the easiest of terms. Where he had been a pruner of government expenditure, he now became an outrageous spendthrift. In this period, his values shifted, from classical to populist liberal, and his two years as a minister clearly reveal the man and his values, his drive and his unorthodox style of work. Macandrew's performance in this role has been strongly criticised but this thesis contends that he was the mainstay of Grey's Ministry. He worked collaboratively when required, and he had the vision and strong personality needed to drive through a radical programme. He performed well in difficult circumstances even though his quirky behaviour antagonised his opponents but he was eventually unsaddled by events beyond his control.

\section{Premier Atkinson}

The impetus of Vogel's Public Works Scheme had faded by 1875 but the full employment generated by a heady investment in infrastructure building had led to inflation and had built an anticipation of heady profits for landowners. Land sales shrank and prices rose, so that many of the newly-arrived immigrants were unable to buy their own land and become self-sufficient. ${ }^{10}$ The gold bonanza had waned, export prices had begun to fall in 1873 and public debt more than doubled from $£ 8,397,000$ in 1870 to $£ 17,388,000$ in 1875. ${ }^{11}$ When Vogel resigned as Premier in mid-Session in 1876 to become the New Zealand Agent-General in London, loan repayments were crippling the country and other forms of fund-raising were needed to repay the debt. ${ }^{12}$ Vogel had avoided imposing any

\footnotetext{
${ }^{8}$ Taranaki Herald, 26 June 1882: 'On the motion of Mr. Macandrew, seconded by Mr. Stewart, Mr. Montgomery was appointed leader'; Wanganui Chronicle, 16 March 1881. 'Mr Macandrew [elected 1853, 24 years non-continuous service] is the "father of the House," having been elected previously to any other member, but is closely followed by Sir W. Fox [elected 1855, 23 years non-continuous service] and Sir G.M O'Rorke [elected 1861].'

${ }^{9}$ Bay of Plenty Times, 28 May 1887.

${ }^{10}$ Raewyn Blackstock, 'The office of Agent-General for New Zealand in the United Kingdom, 1870-1905', $\mathrm{PhD}$ thesis, Victoria University of Wellington, 1970, p. 358. Between 1871 and 1878, a total of 84,125 assisted migrants landed in New Zealand, peaking in 1875 with 31,785. Atkinson reduced the flow to 7,413 in 1877, Grey reduced it further but it was Hall's Ministry in 1880 that reduced it to near zero.

${ }^{11}$ Judith Bassett, Sir Harry Atkinson: 1831-1892, Auckland, Auckland University Press, 1975 p. 46.

${ }^{12}$ ST, 1 September 1876.
} 
new taxes by raising money from loans but the country was now so poor that Parliament needed to find a 'new form of direct taxation that shifted a greater share of the tax burden from poor workers to wealthy landowners. ${ }^{13}$ It was at this point that taxation became a major point of difference amongst the politicians of this period and the balance between indirect and direct taxation began to shift. George Grey, elected to the backbench in 1875, was strongly influenced by John Stuart Mill, and keen to tax the 'unearned increment' of land: his first call for an introduction of income tax and land tax was made in 1876. Grey's reforming party was prepared to increase income tax and death duties in order to make the wealthy carry a larger share of the cost of government, and debate revolved around the most effective method of collecting taxes.

Atkinson became Premier on 1 September 1876, backed by conservative landowners, while the opposition consisted of the radical-leaning Aucklanders headed by Grey, the provincialist Otagoites led by Macandrew, and the Middle Party led by William Montgomery which was made up, predominantly, of liberal-leaning South Island runholders. ${ }^{14}$ By July 1877, after sitting for three months, Parliament had enacted only one Bill, the Education Act which was passed unopposed. When Atkinson presented his first financial statement he considered 'that for the immediate future, the government believe that the need of the country is political rest,' a tepid sentiment which hastened the search for a more effective ministry. ${ }^{15}$

At this point, Macandrew displayed his impatience with parliamentary convention and paraded his liberal politics by supporting Grey's motion opposing Atkinson's financial policy. Macandrew demanded 'that the system of taxation should immediately be altered with the view to impose taxes upon income and property, and relieve the people of the colony from some onerous Customs duties now paid. ${ }^{16}$ His progressively more egalitarian views were now demonstrated by his support for this form of revenue raising, and he spoke fervently: 'In Heavens name, let us for once throw party spirit to the winds! Let us at once adopt a proposal which is calculated so greatly to promote the interests and add to the comfort of every man, woman and child throughout the length and breadth of the

${ }^{13}$ Paul Goldsmith, We Won, You Lost, Eat That! A political history of tax in New Zealand since 1840, Auckland, David Ling Publishing Limited, 2008, p. 54.

${ }^{14}$ Dalziel, p. 223; Wilson, The Grey Government, p. 4 claims that 'To the ardent provincialists, the most important goal to be attained was the placing in power of a Government sympathetic to their provincial interests, irrespective of whether the principles of that Government were conservative or radical.'

${ }^{15}$ Judith Bassett, p. 55; NZPD, Vol. 24, 31 July 1877, p. 127, Atkinson continued: 'Time is needed for the completion and development of our public works: quiet is needed for the consolidation of the social results without which a scheme of immigration and railways in any new country would be a failure.'

${ }^{16}$ Ibid., 17 August 1877, p. 499. 
colony. ${ }^{17}$ Atkinson's supporters strongly rejected what they saw as a land tax that would cost landowners more than town dwellers but although Grey's motion was lost, the concept was launched.

Macandrew supported Grey's liberal manifesto of parliamentary reform, a programme which included manhood suffrage, an equal distribution of seats, abolition of plural voting, payment of members, and triennial Parliaments; the substitution of land and income taxes for customs duties; and land reforms to promote the interests of the smallholder against those of the speculator and the run-holder. ${ }^{18}$ Support for it came from an expanding urban population disturbed by increasing unemployment and by the lethargy of Atkinson's do-nothing government.

\section{Premier Grey}

Historians disagree about the process which led to the emergence of Grey as Premier on 15 October 1877. His appointment may have been engineered by William Larnach, John Ballance, and Robert Stout to help them sell their jointly-owned, large tract of adjacent but worthless land on the Waimea Plains. ${ }^{19}$ Larnach's want-of-confidence motion on 8 October 1877 may have attracted dissatisfied members who wanted to break an impasse and 'with the Micawber-like optimism of politicians in times of incipient depression, they hoped that a new Ministry might turn up with something. ${ }^{20}$ Or it was simply that the dissatisfied principals of the Middle Party, which included members

\footnotetext{
${ }^{17}$ Ibid., p. 507.

${ }^{18}$ J. Rutherford, Sir George Grey: A study in Colonial Government, $2^{\text {nd }}$ ed., London, Cassell, 1961, p. 598. The Colonist, 3 February 1860, used the term Liberal Party to describe a party in the Nelson Provincial Council and it was used widely of Grey's faction, even though it was not a party in the modern sense of the word; W.P. Morrell, New Zealand, London, Ernest Benn Limited, 1935, p. 59, wrote: 'it is not altogether surprising that the first political development after abolition was the emergence of a Liberal party in the General Assembly.'

${ }^{19}$ David Hamer, 'The Agricultural Company and New Zealand Politics, 1877-1886.' Historical Studies: Australia and New Zealand, 10, No. 38, 1962, pp. 141-164.

John Ballance, 1839-93, merchant Wanganui, owner, editor Wanganui Herald, MHR 1875-81, 1884-93, Colonial Treasurer and Minister of Customs, Education, and Stamp Duties (Grey Ministry) 1878-79, Minister of Native Affairs and Defence (Stout Ministry) 1884, Minister of Native Affairs, Defence, Lands and Immigration (Stout Ministry) 1884-87, Premier 1891-93.

William Larnach, 1838-98, banker, businessman, partner Guthrie \& Larnach, ironmongers \& sawmillers, MHR 1875-78, 1883-90, 1894-98, Colonial Treasurer and Minister of Public Works and Stamp Duties (Grey Ministry) 1877-78, Minister of Mines and Marine (Stout Ministry) 1885-87, CMG 1878.

Robert Stout, (Sir), 1844-1930, schoolteacher, lawyer, Member OPC 1872-76, Otago Executive Council 1874-76, MHR 1875-79, 1884-87, 1893-98, MLC 1926-30, Attorney-General and Minister of Lands and Immigration (Grey Ministry) 1878-79, Premier 1884, 1884-87, KCMG 1886, Chief Justice 1899-1926, Privy Councillor 1921.

${ }^{20}$ Judith Bassett, p. 56; NZPD, Vol. 26, 8 October 1877, p. 284.
} 
opposed to the political separation of the islands, as well as Grey opponents, encouraged one of its more obscure members to put the motion in an attempt to oust Atkinson. ${ }^{21}$

Unable to assemble a Ministry, Larnach approached the Opposition group led by Grey who finally emerged as the Premier with a cast of Ministers that amazed and appalled commentators. ${ }^{22}$ Although Macandrew's role in Grey's appointment is unrecorded, his position as the leader of the Otago bloc of members and his provincialist views warranted his appointment as a Minister. ${ }^{23}$ He was first appointed as the Secretary for Crown Lands and Minister of Immigration, then acquired the Public Works portfolio, following Larnach's departure for London as a Government Loan Agent in March 1878. It was in this portfolio that Macandrew famously made his reputation, or lost it.

Sir George Grey's charismatic personality and his radical proposals, boosted by the energy of the frustrated provincialists, sparked a response which flared but failed to ignite and smouldered. He had mobilised a political movement to fight abolition and had produced a cohesive political manifesto which was unusual in that period. Colony-wide support was generated by his programme which easily surpassed Atkinson's bland vision for economic recovery. But once elected, Grey had to balance a parochial Parliament, combative colleagues and conflict in the electorate, all exacerbated by a worsening economy. Without the support of a constituency which was prepared to fight unreservedly for his agenda, Grey was unable to enact his programme of radical political reform during

\footnotetext{
${ }^{21}$ Wilson, The Grey Government, p. 12.

${ }^{22}$ NOT, 12 October 1877.

${ }^{23}$ The Cabinet appointed on 15 October 1877 comprised:

George Grey, Colonial Secretary and Commissioner of Customs;

William Larnach, Colonial Treasurer, Minister of Public Works and Commissioner of Stamp Duties; resigned 5 March 1878;

James Macandrew, Minister of Immigration and Secretary for Crown Lands;

John Sheehan, Native Minister and Minister of Justice;

James Fisher, Postmaster-General and Commissioner of Telegraphs;

George Whitmore, Colonial Secretary.

They were joined on

17 November 1877 by Hoani Nahe, Member of Executive Council;

12 January 1878 by John Ballance, Minister of Education and Commissioner of Customs and from 12 July 1878, Colonial Treasurer; resigned 12 July 1879;

13 March 1878 by Robert Stout, Attorney-General and from 25 July 1878 Minister of Lands and Immigration; resigned 25 June 1879;

2 November 1878 by John Wilson, Member of Executive Council;

17 April 1879 by William Swanson, Member of Executive Council; resigned 15 July 1879;

5 July 1879 by William Gisborne, Minister of Lands, Mines and Immigration;

15 July 1879 by James Thomson, Member of Executive Council and Minister of Lands.
} 
the three sessions he controlled Parliament, although it laid the foundations and shaped the politicians who won the Liberal victory in $1890 .^{24}$

Unfortunately, Grey, whose premiership has been described as 'one of the most desultory and least edifying in our political history', was not a team player. ${ }^{25}$ Wilson considers Grey's irascible nature and inability to compromise with his able ministerial associates contributed to his defeat. Macandrew's governmental experience and his conciliatory skills made him a peacemaker in the Cabinet and he did not desert Grey as did Larnach, Stout and Ballance. But it is more likely that Grey was defeated by having to administer a major change in governing without the support of effective administrative systems. ${ }^{26}$ Following the abolition of the Provinces, so many local issues had to be resolved at a national level that a contemporary commentator protested that 'the House of Representatives, since 1875, has been a monster Board of Works for every part of the colony; and has been unable, at least for ten years, to relieve itself of a burden which it should not properly bear; from a task which it cannot satisfactorily fulfil. ${ }^{27}$ It was a shrinking economy and Grey's inability to control the minutiae of government that destroyed his administration.

Grey set the tenor of his office in his first Ministerial Statement when he claimed that 'every possible retrenchment was necessary' and belt tightening was required. As an example, Ministers' salaries would be the first item to be cut, followed by retrenchments in the Civil Service although it was noted that as the recipient of a British pension, Grey could not draw a salary so he was unaffected by this move. ${ }^{28} \mathrm{He}$ also called for administrative change because 'Two great systems had been running concurrently-the General and Provincial. These two were never merged into one....Their great effort should be to devise a system by which the public affairs of the colony would be grasped by one government. ${ }^{29}$ But having identified his greatest challenge as Premier, he did not have the necessary personal skills to work with his ministers and establish the new system.

Judgment of the new Ministry was swift and editors in the smaller provinces which were the political base of the Opposition were especially shrill: one claimed that Sir

\footnotetext{
${ }^{24}$ Wilson, The Grey Government, pp. 3-4, 60-63.

${ }^{25}$ W.D. Stewart, William Rolleston, Christchurch, Whitcombe \& Tombs, 1940, pp. 126-7.

${ }^{26}$ Wilson, The Grey Government, p. 3.

${ }^{27}$ William Gisborne, New Zealand Rulers and Statesmen 1840 to 1885, London, Sampson Low, Marston, Searle, \& Rivington, 1886, p. 266.

${ }^{28}$ Press, 16 October 1877.

${ }^{29}$ Auckland Star, 16 October 1877, 'Ministerial Statement by Sir George Grey.'
} 
George Grey is 'the last man in New Zealand to administer public affairs under a sense of Ministerial responsibility." ${ }^{30}$ Macandrew was equally criticised: 'No one doubts Mr. Macandrew's administrative ability, but we venture to say that, in all the numerous calculations that have been made outside the House as to the probable construction of the new Government, the late Superintendent of Otago was never included for reasons well understood, but which need not be referred to. ${ }^{31}$ Criticism focused on what was judged to be a bizarre mix of personalities: 'Even the want of a policy is not the chief objection, for how can the country have faith in a Ministry which has so many elements of disunion? How can Mr. Sheehan and Sir Geo. Grey on the one hand, and Mr. Macandrew and Mr. Larnach on the other, agree that the Land fund of Otago is sacred, and not to become Colonial Revenue? ${ }^{32}$ Even in Otago, editors were reserved, writing: 'Despite the presence in the Ministry of two able administrators, in the presence of Sir George and Mr. Macandrew, and a promising one in Mr. Sheehan, we cannot regard the ministry as a strong one. 33

Aucklanders took an opposing view and a correspondent wrote 'Even among those who have been most bitterly opposed to Sir George Grey, many say that it is high time there was a change of some kind, while the great - the very great-majority of people in this province rejoice in no measured way at his accession to power. They have implicit faith in his independence, ability, and unselfish purpose, that he will command supporters from every Auckland constituency if a dissolution should occur. ${ }^{34}$ From abroad, a bemused London correspondent expressed puzzlement to James Hector-James Farmer

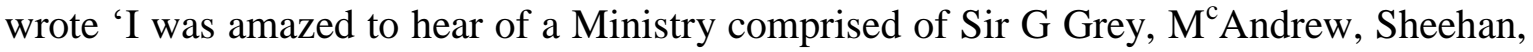
\&c, \&c. I remember the time when Sir G Grey declined a banquet at Otago because he would have to sit at the same table with McAndrew as Superintendent. Can you account for the Change? What has become of Stafford and his party? The Governor will not sleep on a bed of roses with Sir G Grey as Prime Minister. ${ }^{35}$ A contemporary politician and a

\footnotetext{
${ }^{30}$ GRA, 15 October 1877: '(Grey) will carry into the Cabinet - in fact he cannot help it — all the positiveness and self-obstinacy which made it almost impossible for him to maintain amicable relations with any Ministry during the time he was Governor.'

31 Ibid.

${ }^{32}$ Marlborough Express, 17 October 1877.

${ }^{33} \mathrm{BH}, 30$ October 1877.

${ }^{34}$ ODT, 27 October 1877.

${ }^{35}$ Letter: James Farmer (London) to James Hector (Wellington), 14 November 1877, HL, Sir James Hector Letters 1877 MS-0443-3/16.

James Farmer, 1823-95 Estate manager for John Logan Campbell, fortune made from mining investment. Member of Auckland PC 1861-63, 1867-69, 1871-72, MHR 1859-60, 1867-70, and MLC 1871-74. Farmer retired to London where he monitored New Zealand affairs and corresponded with James Hector
} 
published historian, Alfred Saunders, recalled twenty years later: 'No public man ever committed a more evident and unmistakable act of political suicide than Sir George Grey committed, when he declared his willingness to be held responsible, as Premier, for the actions of five colleagues, who had never willingly committed an act of self-denial in their whole lives, and who had, each in his own way, proved himself to be so remarkably untrustworthy. ${ }^{36}$ More likely, it was the arrival of wider political representation and social change which upset the traditionalists, who saw their hold on power crumbling.

The Governor, Lord Normanby, was highly critical of Grey's policies and reported to the Secretary of State for the Colonies that Grey was 'a dangerous \& unscrupulous man who would shirk at nothing which would advance his own ends, provided he could do it with safety to himself....Mr. Larnach is a sick man but a wild speculator \& getter up of companies. Mr Shean (sic) is a pettifogging lawyer the son of a Public house keeper in Auckland. Mr. Macandrews character has been found not to bear very strict interrogation $\&$ Mr. Fisher two or three years ago was a common labourer. ${ }^{37}$ This was a harbinger of the tetchy relationship which developed between governor and premier although Normanby was later complimentary about the railway building programme, and indirectly, Macandrew, the minister responsible for its development. Against this barrage of disbelief and criticism, Grey advanced a radical political agenda which was hailed as the remedy for the country's problems, an amalgam of retrenchment, daring taxation and substantial spending to fire up the economy again, coupled with an expansion of the franchise.

Treasurer Larnach, charged with executing Grey's agenda, took the country by surprise when he presented his first Financial Statement on 20 November 1877 and announced the reversal of a plank of the Immigration and Public Works Act of $1870 .{ }^{38}$ This had allowed provinces to keep the income from their land sales after paying the central government for public works. Now, all land revenue was to become 'colonial revenue' although Larnach would rebate $20 \%$ for works. He also proposed to increase government borrowing in London to $£ 4,000,000$ for investment in major projects, where

until 1891. He consistently criticized Grey and is a useful counterpoint to some of the effusive newspaper reports of the period.

${ }^{36}$ Alfred Saunders, History of New Zealand, Vol. II, Christchurch, Smith, Anthony, Sellars, and Co., 1899, p. 383.

${ }^{37}$ Despatches: Lord Normanby/Henry Herbert, $4^{\text {th }}$ Earl of Carnarvon, 23 Aug 1876 \& 16 Oct 1877, Carnarvon Papers, 30/6/39, Public Record Office, London, quoted in Dalziel, p. 223.

${ }^{38}$ GRA, 5 December 1877. 
Atkinson had intended to borrow only half that sum. ${ }^{39}$ Larnach completed the shock by foreshadowing an increase in taxes as 'we should be prepared to submit to heavier burdens, to meet our obligations to the outside creditors, and conduct the business of the country. ${ }^{40}$ Grey's chances of survival were not rated highly and three weeks later, a want-ofconfidence vote required the Speaker's support to rescue his ministry from defeat. ${ }^{41}$

\section{The Hon. James Macandrew, Minister of The Crown}

In the House, Macandrew was helpful but predominantly parochial. ${ }^{42} \mathrm{He}$ supported grand and expensive plans such as a proposal to build a railway through Central Otago to Cromwell, on to Wanaka and over the Haast Pass to Westland, to join a planned line to Nelson which would extend to Blenheim and south to Christchurch, to complete the circumnavigation of the Middle Island. ${ }^{43}$ His commitment to developmentalism was marked by a proposal that Parliament allocate a reward of $£ 10,000$ to be shared by the first people in the North and the Middle Island to produce 500 tons of sugar from beet. ${ }^{44}$

His personal values emerged in his opposition to two Bills. The pragmatic Macandrew opposed prohibition during a debate on the Local Option Bill, 'I confess I enjoy my tumbler of toddy as much as anyone' which would have confirmed the views of the prohibitionists regarding his character, and reassured the country's imbibers. ${ }^{45}$ The socially conservative Macandrew voted against the Deceased Wife's Sister Marriage Bill which would allow widowers to marry their sisters-in-law. ${ }^{46}$ Earlier in his career, he had opposed the adoption of a nation-wide uniform time as 'he saw no necessity for departing from the sun, which was a sufficient regulator of the time,' a surprising stance given his commitment to technological advance, railway building and better communications. ${ }^{47}$ However, on becoming a Minister of the Crown, the older Macandrew reverted to the

\footnotetext{
${ }^{39} S T, 26$ November 1877. Parliament eventually approved a loan bill of just $£ 2,500,000$.

${ }^{40} E P, 20$ November 1877.

${ }^{41}$ Ibid., 7 December 1877: “'Saved by the casting vote of the Speaker." Surely that is not a dignified or creditable position for a Ministry to occupy. Moreover, had Messrs. Travers, Gisborne, and Johnston been present, and voted in accordance with their previously expressed opinions, the motion of "no confidence" would have been carried and the Ministry defeated.'

${ }^{42}$ Macandrew infrequently spoke at length before becoming a Minister but he provided numerous points of information, procedural motions and conciliatory suggestions to speed debate.

${ }^{43}$ NZPD, Vol. 24, 8 \& 9 August 1877, pp. 286-99 \& pp. 305-07.

${ }^{44}$ Ibid., Vol. 25, 13 September 1877, p. 466; Vol. 26, 3 October 1877, p. 206.

${ }^{45}$ Ibid., Vol. 24, 15 August 1877, p. 438. Cf. ODT, 19 March 1872. Macandrew 'let us into the secret of his mellifluous eloquence [when opening the Graving Dock], which he tells us, is nurtured by the genial influence of "five or six tumblers of toddy."

${ }^{46}$ Ibid., Vol. 25, 13 \& 19 September 1877, pp. 447 \& 559.

${ }^{47}$ Ibid., Vol. 3, 2 December 1868, p. 108.
} 
extravagant behaviour he exhibited in his Superintendent years. It was his style that upset people, rather than his agenda.

Macandrew's performances as a Minister and as Leader of the Opposition have been judged severely by some historians. Olssen suggests that 'He retained his faith in expansion; however, through his persistence he did more than any other man to bring about the rejection of Vogelite policies and to create a climate for retrenchment. ${ }^{48}$ Wilson damns him as Leader of the Opposition: 'Grey had been deposed in 1879 and James Macandrew of Otago put in his place. If the former had proved unstable, the latter was to reveal an entire absence of ability as a leader. ${ }^{49}$ Macandrew's Cabinet colleague William Gisborne was a more sympathetic commentator. Macandrew, he explained, 'holding strong and, at the time, apparently strange views, he was often looked upon as speculative and unsafe. He generally saw a great object afar off, and wished to reach it per saltum; he did not usually give himself time to reach it by sure, though slow, degrees to overcome difficulties, and to carry with him public opinion. Those who thoroughly know him, know that he is, though too sanguine, a farseeing and sensible man. His mind has often conceived the idea which it has been the fortune of others to make a great fact. ${ }^{50}$ Macandrew's ability to identify important issues, his capacity to find solutions before others did, and his propensity to use public money to buy support distinguished his Ministerial tenure.

It was fortunate timing for Macandrew that he took responsibility for the Crown Lands portfolio from Donald Reid, his erstwhile Provincial Council opponent who had become an ally in the anti-abolition debates. Reid had held the portfolio for thirteen months in the Atkinson Ministry and had spent most of that time preparing a Lands Bill which Macandrew inherited and shepherded, unaltered, through the House in late 1877. The Lands Act 1877 consolidated the 'confused mass of colonial land laws, the heritage of provincialism' and repealed fifty-six acts, ordinances and regulations. Its passage marked the ending of the 'old, unfettered freedom of enterprise,' demonstrated concern for working men and introduced a system of deferred-payment tenure nationwide. ${ }^{51}$ Macandrew had a deep interest in land legislation and would have contributed to the

${ }^{48}$ Olssen, Otago, p. 48.

${ }^{49}$ Wilson, T.G., The Rise of the New Zealand Liberal Party 1880-90. Auckland: Auckland University College, History Series No. 6, Bulletin No. 48, 1956, p. 6.

${ }^{50}$ William Gisborne, Rulers and Statesmen, p. 270.

${ }^{51}$ An Act to regulate the Sale or other disposal of the Lands of the Crown in New Zealand 1877, No 29. McLintock, Otago, p. 630-633; W.R. Jourdain, Land Legislation and Settlement in New Zealand, Wellington, Government Printer, 1925, p. 26. 
writing of the Act: that a Ministry should adopt and pass unchanged legislation prepared by its predecessor, indicates the fluidity of politics and the absence of firm party policies at that time. Subsequently, a number of the Grey Ministry's proposed Bills were enacted by its successor. Macandrew handed the Lands and Immigration portfolios to Robert Stout in July 1878, to concentrate on his public works responsibilities.

His great interest was the development of the colony's infrastructure. He delivered his first Public Works Statement in August 1878 after preparation which included inspection tours to familiarise himself with the many projects the Government had been asked to implement. He joined Grey and his entourage on one such tour to the West Coast of the South Island, then went south to Bluff and overland to Dunedin. ${ }^{52}$ Once again, in a life marked by adventurous undertakings and serious mishaps, disaster struck - on 20 February 1878, when the party was re-boarding the Government Steamer Hinemoa off Westport, Macandrew lost his grip and 'had a narrow escape from drowning, as the sea was very lumpy and the night somewhat dark. ${ }^{53}$ When the party had to land by boat at Greymouth the next day, the distressed Macandrew declined to join them and proceeded alone to Hokitika to disembark by tugboat where he resumed his tour and inspected a gaol, lunatic asylum, hospital, the river and harbour works, public offices and other public places. ${ }^{54}$ The Coast's newspapers greeted Macandrew obsequiously and one predicted that 'there is probably no man in the Colony better fitted for presiding over the Public Works Department than the late Superintendent of Otago, the vigor of whose administration has raised that part of the Colony to its premier position. ${ }^{, 55}$ Macandrew responded predictably and generously: he approved the immediate building of bridges at Kumara and Kanieri, and committed money for the building of a road south to the Haast ${ }^{56}$ then proceeded to Jacksons Bay, to become the first Minister of the Crown to visit this isolated settlement. This elicited the comment that 'It is a cause of public congratulation that a member of the Government should see this much-vexed settlement for himself, and especially that that member should be a person of such colonising experience and natural ability, as Mr. Macandrew. ${ }^{57}$

\footnotetext{
${ }^{52}$ Clutha Leader, 22 February 1878. They left Wellington on 18 February.

${ }^{53}$ EP, 22 February 1878. Major catastrophes in his life included the deaths of two children at birth (1852 and 1855), Carisbrook house catching fire in 1859, his bankruptcy and imprisonment in 1861, his near drowning in the same year, the death of his father-in-law in a fire in 1867, Eliza's slow death from cancer in 1875.

${ }^{54}$ WCT, 25 February 1878.

${ }^{55}$ GRA, 23 February 1878.

${ }^{56}$ WCT, 25 February 1878.

${ }^{57}$ Ibid., 28 February 1878.
} 
Grey and his men were not universally popular. Doubts were raised about the Cabinet's ability to work together harmoniously and the New Zealand Tablet editor offered a sectarian spin when he wrote that 'it is undoubted that in our present Cabinet are met a cluster of men differing as widely from each other as it is well possible for men to differ' and he had a low opinion of Macandrew's morals-describing him as 'canny and Presbyterian, orthodox to the heart's core, but like the orthodox of his class, keen and accommodating where accommodation pays. ${ }^{58}$ James Farmer kept up his attack from London on Grey's economics, commenting 'Sir G Grey seems to be having everything his own way in New Zealand. I consider him a most dangerous man to have such power. The communistic doctrines which he advocates may tend to measures most disastrous to this Colony. ${ }^{59}$

Unconcerned, Macandrew continued his tours, and his handouts, to the Waikato to inspect railway, wharf and coal mine; ${ }^{60}$ to Blenheim where he bestowed a railway and a bridge on the community and promised more. ${ }^{61}$ He reassured the Greymouth County Council that their harbour works would receive further funding when Parliament resumed as 'I look upon the works as a national undertaking, which having been so far commenced, must be proceeded with. ${ }^{62} \mathrm{He}$ even won an unexpected accolade from founding provincialist and Superintendent, the Atkinson-supporter William Moorhouse, who reported to his Christchurch constituents on 'the spirit of moderation that had come over the new Ministers. He bore testimony, from his own daily knowledge at Wellington, to their undoubtedly able powers of administration, and was especially forcible on the point that Mr Macandrew, since taking office, was not guided by the belief that Otago was all New Zealand.' 63

\section{Minister of Public Works}

Railways dominated Macandrew's Cabinet career, and were the major focus of his first Public Works Statement which was delivered to almost universal acclaim on 27 August 1878. By this time, it was difficult to find any voice raised against the Government but Macandrew appears to have learned nothing from the repayment problems resulting from Vogel's loans. Macandrew's projects were to be funded by similarly heroic

\footnotetext{
${ }^{58}$ New Zealand Tablet, 26 July 1878.

${ }^{59}$ Letter: Farmer/Hector, 22 May 1878, HL, MS-0443-3/17.

${ }^{60}$ Waikato Times, 27 June 1878.

${ }^{61}$ Star, 3 July 1878.

${ }^{62}$ GRA, 4 July 1878. Telegram: James Macandrew/Chairman, Greymouth County Council.

${ }^{63}$ Hawke's Bay Herald, 22 July 1878.
} 
borrowing, supplemented by income calculated on an extravagant and irresponsible scale. While Olssen criticises Macandrew's recklessness, he does not acknowledge that the electorate welcomed the investment which was, of course, backed by Cabinet. ${ }^{64}$

A Select Committee of November 1877 had recommended that there should be separate managements for the working railways and for railways under construction which required a complete reorganisation of the Public Works Department and the appointment of a Commissioner of Railways for each island. ${ }^{65}$ Macandrew's Statement incorporated this advice and listed the North Island's six lines under construction which he proposed to complete and the eight new lines which he planned to build in the next five years. The Middle Island had nine lines for completion and fifteen for construction, which would entail 'an expenditure for railways in the North Island of $£ 3,733,000$, and in the Middle Island of $£ 4,612,000$; altogether $£ 8,345,000$. ${ }^{66}$ This was an immense increase on the $£ 1,370,100$ which John Ormond, the Minister of Public Works in Atkinson's Ministry had proposed in his Public Works Statement the previous year and marked a return to borrowing and spending on a Vogelian scale. ${ }^{67}$

The five-year budget was to spend the $£ 2,000,000$ remaining from Larnach's 1877 loan, combined with an estimated ordinary revenue of $£ 3,500,000$ to be generated by the railways for that period, plus a new $£ 3,000,000$ loan. To justify this investment, Macandrew itemised the amount of land which would be opened up by ten of the proposed new lines, and dazzled his audience with his bold calculations that 'an area of nearly 4,000,000 acres of Crown land in the Middle Island will be affected by the proposed lines. Much of this land if accessible by rail, and in the market now, would realise $£ 5$ an acre and upwards. Probably we shall not be beyond the mark in estimating that it will realise to the State, at a moderate computation, little short of the whole estimated cost of the railwaysviz., $£ 4,650,000$ - now proposed to be made in the Middle Island. ${ }^{68}$ In the North Island, railways would open up large areas of land for sale in the Thames, Piako, Bay of Plenty, Poverty Bay and Wellington Districts. Taranaki County was scheduled to receive $20 \%$ of the sale price of the confiscated land at Parihaka and Macandrew proposed to levy $15 \%$ of this sum to build a railway through its territory, a proposal which later further tarnished his

${ }^{64}$ Olssen, Otago, p. 48.

${ }^{65}$ AJHR, 1877, I-5, Report of the Select Committee to Inquire into the Present System of Railways Management.

${ }^{66}$ NZPD, Vol. 28, 27 August 1878, pp. 500-509, printed in AJHR, 1878 E-1, pp. iv-vi, Public Works Statement.

${ }^{67}$ AJHR, 1877, E-1, Public Works Statement.

${ }^{68}$ Ibid., p. ix. 
reputation. But other local works suffered as a consequence of the focus on railways. After meeting the previous year's commitments for roads and bridges, Macandrew proposed 'to close the account, and to confine Public Works operations entirely to railway construction' with small amounts only reserved for preparing land for settlement before sale, for roads in Native Districts and for public buildings. ${ }^{69}$

His Statement was received with almost universal acclaim. The colonial press were admiring and many of his opponents discovered Macandrew's hitherto unrecognised talents. Predictably, the partisan Evening Post offered this encomium: 'every thoughtful politician who reads the Statement with attention cannot fail to recognise a sound statesmanlike ability, and power of dealing with colonial affairs on a broad basis, which will add not a little to the already well-earned reputation of James Macandrew. ${ }^{70}$ The editor noted that customs revenue had increased by 39\% between 1872 and 1878 and concluded 'Indeed, the railway policy must be a continuous one, and the results of the past can give heart and hope for the future.' The Lyttelton Times considered 'the Statement more than justifies the reputation Mr Macandrew has long enjoyed as one of the ablest public men of the colony.' ${ }^{71}$ Its virulently anti-Grey competitor, the Press was also positive: 'The proposals it contains are of so comprehensive a character as to practically embrace all consideration of railway construction, either required or possible for the colony to undertake, for many years to come. ${ }^{72}$ This was Populism at its best-the "Coming Man" had arrived and Macandrew's elevation was complete when, on 6 September 1878, he escorted an official party which included the Governor, Ministers and Members of both Houses, as well as local Mayors and Councillors on the first through train from Christchurch to a rejoicing and decorated Dunedin. ${ }^{73}$

Macandrew's successes did not obscure some of his less sensitive behaviour. The Government's need for funds for their public works programme casts a light on his attitudes to Maoridom and land confiscation. In 1884, an interviewer reported that Macandrew never wanted to discuss 'Native affairs' because 'he had never lived in a land overrun with Maoris; knew nothing of their ways and wants, and wanted to know nothing of them. ${ }^{74} \mathrm{He}$ had opposed Stafford's land seizure and war policy in 1868 but few records

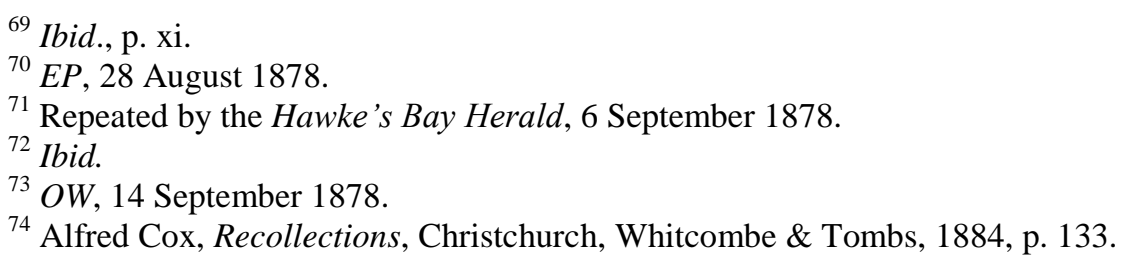


have emerged which detail Macandrew's dealings with Maori. ${ }^{75}$ However, his attitude to Maori did emerge in 1878. The Waimate Plains to the west of Mount Taranaki had been confiscated as war reparations by the Stafford Government in 1867 and in response, the chief Te Whiti o Rongomai established the village of Parihaka on the Plains as a gesture of defiance to the pakeha invaders. The land had not been surveyed or settled by Europeans by March 1878, when, desperate for the income which would be generated by land sales, Grey approved the surveying of the confiscated land around Parihaka. Macandrew's Minute of 22 May 1878, approved by Cabinet, reveals his hardnosed attitude to the pursuit of money and his ignorance of Maori rights:

I desire to submit to the Cabinet the expediency of there being no further delay in taking the necessary action towards surveying for settlement and disposing of the Waimate Block. In my opinion the Government has shown great remissness in not having had this land in the market now. It would have placed us in funds to a very large extent, and enabled public works to be carried on, so far, irrespective of loan...I would suggest that a strong detachment of Armed Constabulary should be located in the neighbourhood, and surveyors started on the block at once: and that the native minister be apprised that such is the intention of the Government unless he is of opinion that good policy absolutely forbids it. ${ }^{76}$

Nothing came of his proposal as Grey was not prepared to risk a fight to eject the owners of the land, By March 1879, local Maori, led by Te Whiti o Rongomai and fellow chief Riwha Titokowaru, had chased the surveyors from their land and a battle of wills ensued. The Hall government, infamously, would adopt Macandrew's suggestion in $1881 .^{77}$

The Public Works Statement included a proposed railway line from Te Awamutu to Inglewood, to link Wellington with Auckland but King Tawhiao was adamant in his refusal to open the King Country to European settlement. Macandrew's optimistic response to Tawhiao indicated his ignorance, deliberate or not, of Maori attitudes to land: 'If those natives have a just conception of the vast revenue which will accrue to them after parting with sufficient land whereby to construct this railway, they will not hesitate for a moment to enter heartily into a transaction which is bound to increase the value of the land which will be left to them very many fold. Moreover, they may earn a large amount of money by devoting their labour to the construction of the line. ${ }^{, 78}$ Suffice to say, the North

\footnotetext{
${ }^{75}$ Saunders, p. 456.

${ }^{76}$ AJHR, 1880, G-2, p. xxv, Reports of the Royal Commission on "The Confiscated Lands Inquiry and Maori Prisoners' Trials Act, 1879".

${ }^{77}$ Timothy McIvor, The Rainmaker A Biography of John Ballance Journalist and Politician 1839-1893, Auckland, Heinemann Reid, 1989, p. 81.

${ }^{78}$ AJHR, 1878, E-1, p. v, Public Works Statement.
} 
Island Main Trunk Railway was not started until 1885 and was not completed until 1908 while the Taranaki connection, from Okahukura to Stratford, did not open until 1932.

\section{The RaIlWays Construction ACT 1878}

In October 1878, Macandrew demonstrated his talent for producing grand visions when he presented his Railways Construction Bill to ratify his Public Works Statement. His Bill contained a five-year railway building programme with each line funded separately instead of through Parliament's usual annual budgetary allocation but members had become more cautious and opposition to his Bill appeared in many forms. It came from those daunted by the scale of the proposed expenditure who said 'When we look at the figures in the schedules one is amazed at any Government proposing that such sums of money should be spent upon works of which we know so little. ${ }^{79}$ Another Member condemned the Bill as 'the most ill-considered, ill advised, impolitic, and unjustifiable measure that has ever been laid before a reasonable House of Parliament' and warned of the dangers of excessive debt. ${ }^{80}$ He suggested that Vogel's scheme of two trunk lines through both islands was a better plan. Another was shocked by the requirement to 'confer powers on a Government which no constitutional Government ought to seek or ought to accept; and we are asked to give up powers which, if we have any proper sense of our own responsibility, we cannot and we dare not give up. ${ }^{81}$ Atkinson was appalled by a Bill which, he claimed, once enacted would give the Government 'the absolute and uncontrolled power of spending six and a half millions of money exactly as they please within the limits of those lines mentioned in the schedule to the bill. I might here point out the enormous pressure to which any Government possessing such power must be immediately subjected. ${ }^{, 82}$ Members whose localities did not warrant a line protested while Macandrew was accused yet again of favouring Otago over the North Island.

Macandrew ended the debate by claiming that he was best qualified to sponsor this Bill because, he claimed, 'I do not think there is any public man in New Zealand whose idiosyncracies are more cosmopolitan than my own' and it passed its Second Reading with a majority of thirty-four votes. ${ }^{83}$ The Railways Construction Act 1878 listed eight lines for construction in the North Island and seventeen in the Middle Island, three more than in his

\footnotetext{
${ }^{79}$ NZPD, Vol. 29, 22 October 1878, p. 1009. Arthur Seymour, Member for Wairau.

${ }^{80}$ Ibid., p. 1015. Richmond Hursthouse, Member for Motueka.

${ }^{81}$ Ibid., 24 October 1878, p. 1071. Alfred Saunders, Member for Cheviot.

${ }^{82}$ Ibid., p. 1058. Harry Atkinson, Member for Egmont.

${ }^{83}$ Ibid., p. 1089.
} 
original Statement, including a line from Amberley to Cook Strait which had been included to win the votes of the Nelson Marlborough members. ${ }^{84}$ Macandrew had vastly expanded the country's railway building programme and he sponsored two further Acts at this time. His amendment to the District Railways Act 1877 permitted the Government to buy private lines and an amendment to the Public Works Act 1876 stirred little debate and passed its Second Reading by thirty-eight votes to two, giving the Government power to take land for railways. It also authorised the appointment of a Commissioner of Railways and an Engineer in Charge of Railways in both Islands, and regularised a number of procedures. ${ }^{85}$

The triumphal inauguration of the South Island Main Trunk Railway in September 1878 was the pinnacle of Macandrew's ministerial career. Grey's Cabinet, never closely knit, started to unravel in early October. Despite Macandrew's legislative achievements, Grey's unpredictable behaviour destabilised his Government and Cabinet did not function well. William Russell claimed that 'a more disconnected, disunited, ill-assorted party than those honorable gentlemen who call themselves Ministerial supporters never sat within this House before. It reminds me of a comet. They have a great, brilliant, erratic head, but their body tails off, diminishing in light, until it vanishes into nothing at all. ${ }^{86}$ When the City of Glasgow Bank was declared insolvent on 2 October 1878, the repercussions shook the Empire: the collapse, combined with falling wheat and wool prices, eventually destroyed the Grey Government and ended Macandrew's ministerial career.

Personal tensions in Cabinet accelerated the process. John Ballance had been appointed Colonial Treasurer on 12 July 1878 to replace Larnach who had resigned in March. Ballance presented his first Budget on 6 August which did not deliver the savings Grey had promised, rather, Ballance’s 'estimated expenditure for 1878-9 (£4,193,500) exceeded that of the previous year by $£ 224,000 .{ }^{, 87}$ His generous gift to the voters, 'a free breakfast table' which was to be created by the reduction of customs duties on grain, flour, tea, sugar and more, was to be offset by the introduction of a land tax-a halfpenny tax in the pound on the unimproved value of properties worth more than $£ 500$-while his proposed income tax on company profits and a tax on beer were both abandoned in the

\footnotetext{
${ }^{84}$ Railways Construction Act 1878, No. 45.

${ }^{85}$ District Railways Act 1877 Amendment Act 1878, No. 21 and Public Works Act 1876 Amendment Act 1878 , No. 44.

${ }^{86}$ William Russell (Captain, later Sir), NZPD, Vol. 29, 10 October 1878, p. 590.

${ }^{87}$ Rutherford, p. 612.
} 
face of fierce opposition. ${ }^{88}$ However, Grey's impetuous withdrawal of the tax bills without consultation so incensed Ballance that he threatened to resign. Although Ballance did not follow through with his threat on this occasion, it confirmed the Cabinet's volatility as its members struggled to work with the autocratic Grey. Nor did Grey follow through on his promise of sweeping electoral reform when in another fit of pique, he withdrew his Electoral Bill. Frustrated by the Legislative Council's amendment to remove the voting rights of Maori ratepayers, Grey withdrew it from the Order Paper. ${ }^{89}$ Grey's Electoral Bill did not include the triennial parliaments, the vote for all men and the redistribution of electorates which he had promised but it would have extended the franchise to all men who had been in New Zealand for two years and had lived in one electorate for six months.

A year later, in August 1879, Grey went to the country for an election triggered by greed and fuelled by animosity. The government's drawn-out collapse was linked to the involvement of some of its ministers in land speculation in Southland and Macandrew may have precipitated its demise by his association with this matter. In February 1879, he was honoured by the naming of Macandrew Township, on the Waimea Plains of Southland near Riversdale, adjacent to the Mataura River, at the centre of the struggling Waimea Estate owned by the Agricultural Company, whose Directors were Ballance, Larnach, Stout and Vogel. ${ }^{90}$ The timing is noteworthy. The Township was gazetted by Macandrew's successor as Minister for Lands, Robert Stout, at the same time as Colonial Treasurer Ballance turned the first sod of the Waimea Plains Railway, the first line to be built under Macandrew's District Railways Act $1878 .{ }^{91}$ Vogel, in London, advertised the railway's commencement, reassured English investors that the Estate would be accessible and land values would rise, at which investors subscribed enthusiastically to a scheme backed, supposedly, by the New Zealand Government. ${ }^{92}$ When Grey realised what Ballance and Stout had done, he insisted they resign either their Directorships or from Cabinet. They chose to stay in Government but the loss of trust between Ministers meant an end to effective Cabinet functioning. This led to both men resigning their portfolios later in the year.

\footnotetext{
${ }^{88}$ NZPD, Vol. 29, 6 August 1878, p 81 onwards. The Beer Tax Bill and the Company Income Tax Bill were dropped by Grey on 4 October 1878.

${ }^{89}$ Ibid., Vol. 30, 31 October 1878, p. 1263; McIvor, p. 79.

${ }^{90} S T, 28$ February 1879.

${ }^{91}$ ODT, 28 January 1879.

${ }^{92}$ NZPD, Vol. 27, 26 November 1877, pp. 467 \& 472; Dalziel, p. 224 claims that Vogel's 'quarrels with Macandrew had always been political rather than personal and after Vogel left New Zealand they carried on a desultory but amicable correspondence'. Some of these letters are at ATL, MSY-1335.
} 
Should the naming of the township, which never grew, be taken at face value as a simple acknowledgment of government service, or was it recompense for Macandrew's support of the desperate directors? ${ }^{93}$ Hamer claimed Vogel justified accepting a Directorship of the Agricultural Company while also employed as Agent-General, contrary to official policy, because three ministers - Ballance, Stout and Macandrew-knew of his activities, which Vogel conveniently interpreted to mean that he had official Government approval. ${ }^{94}$ Hamer affirms that there is a note in the Grey Papers that 'Macandrew denied to Rees - and Dignam - that he knew of it — also to Sir G. Grey himself. ${ }^{95}$ Whitmore is supposed to have received a written denial from Macandrew, and Ballance declared that only Stout and he knew about it.' If the scheme existed, Macandrew's prison experience would surely have made him wary of involvement in such dubious machinations but it is difficult to imagine that he did not have an inkling of his colleagues' plans. ${ }^{96}$ Stout's appointment of Macandrew as Minister of Lands, Immigration and Mines in August 1884 may have been Macandrew's belated reward. Macandrew's later behaviour adds to the puzzle. On 14 October 1884, in the debate for the Second Reading of the District Railways Leasing and Purchasing Bill, which would allow the Government to buy, amongst others, the Waimea Plains Railway and rescue the Agricultural Company from its debts, Macandrew fiercely opposed the purchase of that line, proclaiming 'I maintain it is not the duty of the State to relieve those who have entered into bad speculations...I think that, as a matter of public policy, we ought not to agree with it. ${ }^{97}$ This is not the stance expected of an expectant investor. The issue is clouded because he abstained from voting for the Bill's third reading - the Speaker had specifically stated that 'Honourable members having any pecuniary interest are not entitled to vote' and Ballance, Macandrew, Stout and Vogel did abstain—-but Larnach did not. ${ }^{98}$

Cabinet disharmony generated by the disclosure of the Agricultural Company was exacerbated in February 1879 when Ballance appointed David Luckie as Government

\footnotetext{
${ }^{93}$ ST, 4 December 1886.

${ }^{94}$ AJHR, 1880, B-4A, No. 93, (Enclosures.), p. 32, Five Million Loan, Papers Relating to its Negotiation, etc.

${ }^{95}$ Hamer, The Agricultural Company, p. 147.

${ }^{96}$ Letter: John Balance/Vogel, 1 March 1878, Vogel Papers, ATL, MS Papers-2072-25. When Larnach retired from Cabinet to go to London, Ballance wrote to him 'I leave the explaination of the matter to Macandrew, who will probably write you fully on the subject.' The large number of letters between Ballance, Vogel and Macandrew extant show they were allied against Grey and regularly shared political gossip.

${ }^{97}$ NZPD, Vol. 49, 14 October 1884, pp 426-33.

${ }^{98}$ Ibid., p. 444. Macandrew voted in the next division of the House that day. See also David Hamer, 'The Law and the Prophet: A Political Biography of Sir Robert Stout (1844-1930)', MA thesis, University of Auckland, 1960, p. 119.
} 
Insurance Commissioner on a salary four times the official rate, over Grey's objection. The salary was reduced but Grey's antipathy for Ballance was not. In April, Macandrew advised Ballance not to speak to Grey alone and Cabinet stopped meeting soon after: it was not long until 'Grey was issuing decrees as though he had no ministers and no such institution as cabinet even existed. ${ }^{99}$ Stout resigned in June, ostensibly to focus on his legal career and Ballance departed in July after a confrontation in Grey's office which almost came to blows, then Macandrew threatened to resign but Grey talked him out of it. ${ }^{100}$ In this poisonous atmosphere Parliament met on 11 July, with the economy hit by the failure of the City of Glasgow Bank. A consequent rapid retrenchment of credit and the collapse of land and export prices ensued. ${ }^{101}$ Grey was defeated twice in the House before he succumbed to a want-of-confidence motion on 29 July. ${ }^{102}$ His animosity for the new Governor, Sir Hercules Robinson, was reciprocated: Grey expected to have his request for a dissolution denied but Robinson called his bluff and sent him, unwillingly, to the polls. $^{103}$

Despite their collective antagonism for the Government, some in the press continued to speak well of Macandrew. The Southland Times, one of his consistent critics, acknowledged his coalition building skills when it reported on 'the Minister of Works playing the part of go-between, and...the "administer of soothing medicine." 104 The reporter acknowledged Macandrew's political skills but despite his charm, saw little hope for the Government: 'Sir George Grey is really much beholden to Mr Macandrew; the latter has stuck to him with unswerving fidelity, and should the Ministry by any chance tide over the present difficulty, they will owe a great deal to Mr Macandrew's buoyancy, sagacity, and shrewd common sense. However, we do not think it is possible for even "Old Mac" to save his party; discontent is chronic, and there is such very much better men waiting, and ready to supplant the present occupants of the Ministerial benches.' Old Mac was 60.

The Opposition was much less complimentary. Macandrew's management of the railways was criticised when a 'Railway Map Inquiry Committee' accused him of

\footnotetext{
${ }^{99}$ Edmund Bohan, To Be a Hero: Sir George Grey 1812-1898, Auckland, HarperCollins (New Zealand), 1998 , p. 268.

${ }^{100}$ Ibid., p. 269.

${ }^{101}$ McIvor, p. 80.

${ }^{102}$ NZPD, Vol. 31, 29 July 1879, p. 304.

${ }^{103}$ Despatches: Sir Hercules Robinson/Sir Michael Hicks Beach, 9 August 1879, ANZ, Wellington, G $261 /$ p. 156; McLean, Governors, p. 92.

${ }^{104} S T, 15$ July 1879.
} 
malfeasance. ${ }^{105}$ The Report claimed that an extension of the Thames Railway, from Te Aroha to Grahamstown, in Grey's Thames constituency, had been added 'under instructions from the Hon. the Minister for Public Works' to a map requested by Edward Richardson. ${ }^{106}$ As construction had commenced, seemingly without the permission of the House, electoral bribery with public money was suggested, although it appears it may have been a further example of Macandrew's impatience with procedure - a simple carelessness, a recurrence of a lifelong pattern. ${ }^{107}$ He maintained that permission to build the line had been given by a previous Minister in 1873 and the Inquiry Committee was directed to reconvene, with a different membership. ${ }^{108}$ Unfortunately for Macandrew, this Committee agreed with its predecessor but Parliament adjourned on 11 August and he avoided penalty. ${ }^{109}$ His judgment was condemned by a Royal Commission in 1880 when the Te Aroha-Grahamstown line was criticised as extravagant and discontinued although it was recommenced and reached Thames in $1898 .{ }^{110}$

Unsurprisingly, Macandrew was subdued when he presented his second Public Works Statement, on 7 August 1879 in the dying days of both the session and the Grey Ministry: he knew that Parliament had been prorogued and his party was unlikely to win the forthcoming election. Now, his concluding words were somewhat limp: 'I have carefully abstained from saying anything debateable; and shall conclude by expressing a hope that, into whatever hands the future administration of the Public Works Department may fall, the Railway policy which I had the honor to enunciate last session may be earnestly and vigorously prosecuted.'111

While a Minister, Macandrew may have been lulled by media praise and he appeared to be unaware that many of the public held negative views of him as he ignored established protocol and manoeuvred to achieve goals speedily. Macandrew was also accused of extravagance in using special trains for his official visits which delayed

\footnotetext{
105 Wanganui Chronicle, 30 July 1879: 'Thames Railway Map.-The Hon James Macandrew, the Minister of Public Works, stands convicted of having tampered with a public document after it had been laid upon the table of the House.'

${ }^{106}$ AJHR, 1879, I-2, Report of the Railway Map Inquiry Committee, 23 July 1879.

${ }^{107}$ NZPD, Vol. 31, 24 July 1879, p. 210.

${ }^{108}$ Ibid, 7 August 1879, p. 454.

${ }^{109}$ AJHR, 1879, I-2A, Report of the Railway Map Inquiry Committee (Revived), 8 August 1879.

${ }^{110}$ Ibid., 1880, E-3, p. vii, Report of the Railways Commission.

111 Ibid., 1879, Session I, E-1, pp. iii, Public Works Statement.
} 
ordinary services and created disruption. ${ }^{112}$ His behaviour in Parliament in late 1879 was a repeat of his behaviour as Superintendent of Otago in 1860 when he spent a large amount of time and energy defending his actions in debates of excruciatingly minor detail. These would have taken a toll on a man who customarily spoke of grand visions in sweeping terms. His stress emerged in a letter to his daughter Mabel, aged twelve, which reflects the importance of family to him when he wrote 'you must excuse me for having been so long in replying to your various letters. I have had so much to do and to think about that days and weeks slip away before I know where I am hence the delay. You may rest assured that I do not forget my dear little girl and that your letters as well as those from Arthur Alice and all of you afford me very great pleasure and satisfaction.' ${ }^{113}$ His Ministerial performance would have contributed to the loss of a want-of-confidence vote for Grey's Ministry on 29 July which was quickly followed by a dissolution of Parliament and a return to the stump. Grey's efforts to impose a radical manifesto on New Zealand politics had failed, overwhelmed by economic conditions: 'his Ministry had been ineffectual, inefficient, and extravagant; its land tax had become extremely unpopular' and he was accused of stirring up further conflict with Maori by the attempt to open up land at Parihaka. ${ }^{114}$ Grey had not been helped by his bickering and insensitive Ministers.

Macandrew returned home to stand again for Port Chalmers, his old seat, which he had won in 1871 but had deserted for Dunedin City in 1875. During the election campaign in September 1879, Macandrew expounded his economic philosophy. ${ }^{115} \mathrm{He}$ opposed any increase in taxation because most of it went to local body subsidies and 'the sooner that the local bodies raised their own revenues, the better it would be both for the Colony and for the localities themselves.' He admitted to being appalled that the colony owed twenty million pounds - this despite his responsibility in amassing it. He noted that after deducting the ultimately recoupable eight millions of railway debt, repayment 'involved the finding of $£ 13,000$ every week, to be sent to the English creditor.' Such debt, he considered, could only be lightened by reducing expenditure and sharing the load wider-

\footnotetext{
${ }^{112}$ NZPD, Vol. 31, 23 July 1879, p. 197: "Half-an-hour afterwards, when he had had his "wee bit crack" with his friends, he would get into his special train and go on...If the honorable gentleman had heard public opinion expressed as I heard it upon one occasion, when some hundred and fifty people were kept waiting for the departure of the train while the honorable member was conversing in a hotel close by, he would have understood what public opinion was.'

${ }^{113}$ Letter: James Macandrew to Mabel (Mavie) Macandrew, 18 August 1879, KWMSS: Colin, his oldest child, was now thirty, Alice was fifteen and Arthur was the youngest at ten. Presumably the younger children were cared for by the older daughters in Macandrew's absences.

114 Judith Bassett, p. 72.

${ }^{115}$ OW, 4 September 1879.
} 
the solutions he returned to in bad times-frugality and a larger population. His speech included a proposal that was to haunt him for the rest of his life, because it was so forwardlooking and hence, unacceptable to his conventional brethren. He suggested that New Zealand adopt a paper currency that was not gold-based. He acknowledged that New Zealand would need to keep on borrowing for development and suggested that the loans be raised locally - why pay interest to England when the same money could be spent in the Colony? He added 'he could see no great difficulty in the way of the State paying for its public works in its own bonds, bearing interest... But why should not these bonds be issued in small amounts and made legal tender in New Zealand?... They would have this advantage over bank notes, that they would bear interest, and as such would speedily supplant bank notes.' The Colony could afford to pay the interest on existing loans out of export earnings while land sales would generate the gold required to pay off the debt.

It was in this campaign that he also enunciated his political philosophy most clearly, and confirmed his commitment to the utilitarianism of Jeremy Bentham and John Stuart Mill, although his Presbyterian reticence might have avoided reference to the pleasure principle. ${ }^{116} \mathrm{He}$ insisted that 'the greatest possible happiness to the greatest possible number had been his pole-star all along. Progress, whether in opening up the country by roads and bridges, in extending the means of education throughout its length and breadth, in promoting intercourse by steam with the neighbouring provinces and colonies and with the Mother Country, in the construction of railroads and docks, the encouragement of manufactures, the introduction of immigrants, the suppression of crime and the nipping it in the bud; - these and many other things had been his watchword, not in word but in deed, for he could point to each and all as realities which it had been his lot chiefly to influence'

His commitment to independent local government was still strong. He had previously advocated that 'the boundaries of the counties should be greatly enlarged, and that their powers and responsibilities should be increased so as to give them absolute control over all local matters, and to enable them to carry on and maintain all public works, inclusive of district railways, within their own territory. ${ }^{117}$ He proposed to reduce the number of local bodies and give them 'the administrative powers which were exercised by the Provinces, with power to borrow under certain conditions which the provinces never had; all local railways and other works should then devolve upon the counties. ${ }^{118}$

\footnotetext{
${ }^{116}$ Ibid.

${ }^{117}$ Ibid., 19 August 1879.

${ }^{118}$ Ibid., 4 September 1879.
} 
However, with the Government insolvent, subsidies for local bodies would have to end and the imposition of an income tax would be necessary. He believed that 'those who require roads to be made and streets to be maintained should be taxed by themselves for that purpose, and not by the General Government...the colony should confine its taxing power to the raising of sufficient money for the protection of the public creditor, for the protection of life and property, and for the maintenance of peace, order, and good government throughout the Colony. ${ }^{119} \mathrm{He}$ repeated yet again his unwavering, lifelong belief that population expansion would ease New Zealand's economic problems: 'If this Colony is to prosper, its population must be greatly increased, and the more people we have in the country, the better it will be for all...instead of supporting 400,000 people I believe it will taken many millions of people to beneficially occupy this country...every facility should be given for the acquisition of moderately-sized farms, not by the thousand but by the hundreds of thousands... and I, for one, say that we could afford to plant 200,000 families - aye, twice 200,000 - upon 50-acre farms without interfering with those men who desire to occupy more extensive holdings and are in a position to acquire them.' As usual, decentralisation, self-interest and self reliance were his recipe for prosperity.

With his usual persuasiveness and by outfacing his critics, Macandrew won his seat by a small margin on 6 September 1879 . He received three hundred and sixty-three or $58 \%$ of the six hundred and thirty votes cast, to defeat sitting member James Green who had opposed Grey in the House. ${ }^{120}$ From this victory, he morphed effortlessly into the role of elder statesman of the Port, and retained the seat, unchallenged, in the 1881 and 1884 elections.

\section{Almost PREMier}

Grey appeared to have won the election but the House had to confirm the election result. John Hall, Member for Selwyn, the new Leader of the Opposition, promptly moved a want-of-confidence vote which was carried on 3 October, forty-three to forty-one and Grey immediately relinquished leadership of what was now the opposition party to Macandrew. ${ }^{121}$ Edward Stevens' prediction of 1871 had come to pass and the 'gamblers and thimble-riggers' were ejected. The "prudent" party, including Stevens, was now returned to restore solvency.

${ }^{119}$ Ibid., 6 September 1879.

${ }^{120}$ AJHR, 1879, Session II, H-18, p. 3. $80 \%$ of the eligible voters of Port Chalmers voted in this election when the New Zealand figure for voter turnout in contested seats was $66.5 \%$.

${ }^{121}$ NZPD, Vol. 32, 3 October 1879, p. 162. 
Macandrew became Leader of the Opposition as a compromise candidate, neither because of his own ambition nor the approbation of his colleagues. As a commentator noted 'Mr. Macandrew is not, we believe, anxious for the post of Premier, but his acceptance of the task of forming a new Government would probably lead to a successful result, as of all the members of the Ministry, he has the fewest personal enemies in the house. ${ }^{122}$ But Sir George Grey did not make his task easy and it was soon reported that 'Mr. Macandrew exhibited incapacity to lead, and thus the Hall party had the gratification of seeing their only dangerous opponent ignominiously deposed through the stupidity of his professed friends and supporters. ${ }^{123}$ Macandrew tried, unsuccessfully, to emerge from his predecessor's shadow but Grey continued to act as the putative leader of the Liberals and refused to support their political programme. ${ }^{124}$ In addition, Macandrew was forced on to the defensive and his leadership was handicapped by Atkinson who justified his economic austerity programme by relentlessly assailing Macandrew's performance as a minister.

Although Grey had been evicted from the Treasury Benches, Hall's majority was insecure and when Macandrew moved his own want-of-confidence motion on 10 October, Hall stalled debate on it for two weeks while he worked to consolidate his majority. That philosophical differences were minor and that few values divided the politicians of the day became apparent when the Conservative Hall introduced his remarkably un-Conservative Triennial Parliaments and Franchise Bills. Manhood suffrage had been a mainstay of the Liberal's reform programme but Grey did not enact it during his term and by introducing these bills, Hall hoped to force Macandrew to oppose his own principles. ${ }^{125}$ Macandrew responded by challenging every Government motion to force his want-of-confidence motion to the top of the order paper. ${ }^{126}$

Members of the Grey, Ballance and Middle Party factions coalesced behind Macandrew to position him as Premier, which would be the pinnacle of his career. ${ }^{127}$ Having gained the support of a majority, his success was assumed and the press forecast

\footnotetext{
122 ODT, 13 September 1879.

${ }^{123}$ WCT, 7 May 1880.

${ }^{124}$ Press, 2 June 1880: 'Sir George Grey, acting apparently in distinct independence of Mr. Macandrew's party, has given a week's notice of his intention to move for the repeal of the property tax.'

${ }^{125}$ Hamer, The Agricultural Company, p. 80.

${ }^{126}$ Rutherford, J., p. 626.

127 Wanganui Chronicle, 16 October 1879: 'The Liberal Association have decided to support the Liberal Party under the leadership of Mr. Macandrew'; Wanganui Herald, 1 November 1879. 'All this time the actual position of parties was this-Ministerialists 41, Opposition 45; and could a division have been forced this would have been the report of the tellers.'
} 
his Cabinet: 'The proposed Macandrew Government will probably consist of Macandrew, Premier and Colonial Secretary; Ballance, Treasurer and Customs; Montgomery, Public Works; Stewart, Attorney General; Sheehan, Native Minister; Pyke, Lands and Mines; and Shepherd, Postmaster General. ${ }^{128}$ But it was not to be-four Auckland members, Colbeck, Hurston, Swanson and Wood, ostensible Grey supporters who were expected to vote for Macandrew, gave their votes to Hall in return for commitments including more money for public works in their province. This was an act which resonates yet in New Zealand political lore and saw them labelled forever as the 'Auckland Rats'. ${ }^{129}$ It was a sorry outcome for Macandrew as William Swanson had been a Minister and colleague in the Grey Cabinet for its last three months, and Reader Wood, a Liberal Party Executive Committee member, had actually nominated Macandrew as leader of the party. Unfortunately for him, Macandrew was the victim of normal parliamentary tactics of that period when hometown allegiance trumped party loyalty. ${ }^{130}$ It would have been small comfort to Macandrew that loyal Otago voters returned him unopposed in the 1881 election while Auckland jettisoned Wood and Colbeck, and returned him again unopposed in 1884 when Swanson lost his seat.

With a severe downturn in the economy, public opinion turned against the Greyites, and supporters who had lauded Macandrew enthusiastically in 1878 were now scathingly critical. ${ }^{131}$ The Evening Post abandoned Grey, attacked Macandrew, and endorsed Hall in the coming confidence vote, claiming that 'The Grey Ministry...promised vast retrenchment in the public expenditure and a general lightening of the public burdens... [They] not only inherited a large surplus and a million of unexpended loan, but they also borrowed two millions and a half more during their two years of official life. All these large sums they have spent, much of it, we fear, utterly thrown away and wasted. ${ }^{, 132}$ Another editorialist damned Macandrew, claiming that 'a section of the Auckland members at Wellington, awakened to the danger of allowing a Macandrew Ministry to perpetuate a reign of financial terror over the colony, have used their position as masters of the situation to secure for the Auckland district some equitable redress for the wrongs done to it in the unjust allocation of the loans under the Public Works and Immigration

\footnotetext{
${ }^{128}$ GRA, 13 October 1879.

${ }^{129}$ Jean Garner, By His Own merits: Sir John Hall-Pioneer, Pastoralist and Premier, Hororata, N.Z., Dryden Press, 1995, p. 165.

${ }^{130}$ Wanganui Herald, 5 November 1879.

${ }^{131}$ EP, 28 August 1878.

${ }^{132}$ Ibid., 15 October 1879 . It continued 'They have spent all their ordinary revenue, all their first surplus and $£ 3,500,000$ of borrowed money, and yet are nearly a million short.'
} 
Policy. ${ }^{133}$ Stevens told Stafford that 'The public and private gambling of the past 9 years must cease' and James Farmer was particularly acerbic: 'I hope that Sir G Grey and his communistic party have taken final leave of Official life. It will take years to undo the mischief they have done the Colony., 134

Odium was further heaped on the Grey Ministry, particularly for what the new Ministry regarded as gross extravagance in the depressed economic climate. In October, the reinstated Colonial Treasurer Harry Atkinson reported that 'The colony is, I venture to say, in a state of complete darkness as to our real financial position. ${ }^{135}$ He noted that almost half of a proposed loan of $£ 5$ million had been committed 'before we have the slightest news from Home as to whether it is likely we shall get the money... without the slightest knowledge of whether we can meet our engagements.' A month later, criticism of Macandrew was sterner: 'When we remember that the Public Works scheme of 1878 was to take five years to complete, that the expenditure from loan was only to be at the rate of some $£ 900,000$ a year, and that by a special provision of 'The Loan Act, 1879,' no money raised under it was to be spent without appropriation by Parliament, we... have come to the conclusion that Parliament has not been treated with frankness in this matter, and that its authority has been disregarded. ${ }^{136}$ In December, Atkinson claimed that 'New Zealand is the most heavily-indebted and the most heavily-taxed country in the whole world...It is attributable solely to excessive borrowing' and he proposed to lay down 'as a stringent rule that for the future not one shilling of borrowed money shall be expended except on works which will at once yield a profit at least equal to the annual interest upon their cost., ${ }^{137}$ Having frightened the electorate sufficiently, he increased customs duties and imposed a property tax. While Grey's men challenged Atkinson's figures, Hall lamented to Vogelthe confidante of both sides of the House - that 'If [NZ's] finances had remained for another 6 months under their old management, I do not believe that all our \& your exertions would have averted a smash. Macandrew still refuses to believe in the liabilities

\footnotetext{
${ }^{133}$ Waikato Times, 28 October 1879.

${ }^{134}$ Letter: Stevens/Stafford, 28 December 1879, ATL, MS-2050; letter: Farmer/Hector, 1 January 1880, HL, MS-0443-3/19.

${ }^{135}$ AJHR, 1879, Session II, B-02, pp. 1 \& 7, Speech of the Colonial Treasurer on the Financial Position of the Colony, $14^{\text {th }}$ October 1879.

${ }^{136}$ Ibid., B-02A, p. 5, Financial Statement in Committee of Ways and Means, $17^{\text {th }}$ November 1879, by the Colonial Treasurer.

${ }^{137}$ Atkinson, Harry, 'Notes upon the Taxation and Indebtedness of New Zealand', 12 December 1879, Vogel Papers, ATL, MSY-1335.
} 
we found; and Grey told Fitzgerald that with an additional $£ 80,000$ a year he would be satisfied. $^{138}$

Predictably, when Premier Hall wanted to lay blame for the sluggish economy, he launched four Royal Commissions in 1880 to review the performance of the Grey Government. Macandrew's conduct as a Minister was the focus of two enquiries, into the Civil Service, and the Railways. ${ }^{139}$ While Grey's Cabinet was responsible for the expensive construction programmes, Macandrew's casual management style and his reputation for corner-cutting made him a convenient scapegoat and he was fortunate to escape a reckoning but his credibility was destroyed when Hall's Royal Commissions censured the Grey regime and its management of the Public Works Department. Although neither Report identified Macandrew by name, his many ad hoc decisions and his careless administration of his Department were criticised. The Commission on the Civil Service in New Zealand reported that 'We have been able to find very little to commend the results of its [Public Works Department] management, and have come to the very painful conviction that New Zealand has not received good value for the large sums that have been expended.' ${ }^{140}$ This Commission also accused Macandrew of inadequate oversight of William Conyers, Commissioner of Railways for the Middle Island, who, it was later reported 'has capital invested in a firm contracting with the department of which he is head, and that his receipts from this capital depend on the success of that firm. ${ }^{141}$ Further accusations of cronyism and fraud tabled in Parliament claimed that the Dunedin Locomotive Engineer Alex Armstrong had not only, improperly, bought material from Guthrie and Larnach but had replaced it with inferior stock to assemble wagons. ${ }^{142}$ The accompanying Railways Commission found a 'fatal' mistake was 'the making of railways in some parts of the colony far in advance of existing settlement, and consequently of an amount of traffic adequate to their support. ${ }^{143}$ Despite these judgments, the long view

\footnotetext{
${ }^{138}$ Letter: John Hall/Vogel, 1 January 1880, Hall Papers, ATL, MSX-0908, p. 82.

${ }^{139}$ AJHR, 1880, E-3, Report of the Railways Commission, and H-2, Report of the Royal Commission on the Civil Service of New Zealand.

${ }^{140}$ Ibid., H-2, p. 8.

${ }^{141}$ Ibid., p. 7.

${ }^{142}$ Ibid., H-2E, Correspondence Relative to a Supply of Galvanised Iron and H-2D, Telegram from Locomotive Engineer, Christchurch, Relative to Defective Railway Wagons.

${ }^{143}$ AJHR, 1880, E-3, p. iv.
} 
suggests that Macandrew's railways were logistically astute as nearly all of his proposed lines were eventually built - it was his timing that was wrong. ${ }^{144}$

Throughout his life, Macandrew's ambitions outstripped available resources but despite his irresponsible spending, one historian claimed that 'he at one time commanded a far greater amount of popularity and applause than has ever been given by the New Zealand public to men of a far higher stamp, to far more unselfish patriots, to men of more self-control, of greater ability, or more reliable judgment, and more trustworthy integrity. ${ }^{145}$ The borrow-and-spend policy introduced by Vogel was appealing as an economy-stimulator and Macandrew, on becoming Minister of Public Works, continued it, in response to the public's demand for government intervention in the economy. His misfortune was to be a minister at a time of severe economic downturn, but it was his cavalier behaviour when in office that made him a scapegoat when the world recession affected New Zealand.

As Superintendent and as a Minister, he spent without restraint, despite his onetime enthusiastic support of retrenchment. Given his record for retrenchment earlier in his career, it is surprising that he did not support Atkinson in 1876 and that he was prepared to launch a spending round in 1877. Nor did he support Hall's severe cutbacks from 1879 onwards, but persisted in advocating continuing government investment to solve the country's woes. There are few clues to explain his inconsistent attitude to government spending but he appears to have followed a similar path to Vogel. Both discovered that leadership of a province, and a country, with responsibility for the welfare of their citizens, tended to change a politician's values.

${ }^{144}$ Gary Hawke, The Making of New Zealand: An Economic History, Cambridge, Cambridge University Press, 1985, p. 81: 'Claims that railways were built in the wrong places are unsubstantiated but difficult to refute. That they were spread amongst the provinces for political reasons does not imply that they varied much from optimal locations...A map of the railway system at the end of the 1870s suggests progress towards the eventual national system, not a set of rewards for political allegiance.'

${ }^{145}$ Saunders, p. 452. 



\section{CHAPTER 8}

\section{EPILOGUE AND CONCLUSION 1879-1887}

Macandrew's commitment to improving social conditions in New Zealand was demonstrated in his further seven years of active political service during which he continued to promote his passions of settlement and development. Chapter eight will review Macandrew's final years in Parliament, as leader of the opposition party and as a backbencher where, as the Father of the House, he was indulged by many but treated seriously by few.

\section{LEADER OF THE OPPOSITION 1879-1882}

The premiership evaded Macandrew but he continued to represent Port Chalmers until his accidental death in 1887. He led the opposition for three years of the Long Depression when no other politician challenged him for the job and George Grey, the Liberals' eminence grise, continued to destabilise the party. ${ }^{1}$ At this time the Liberals, opined Walter Pilliet, Member for Stanmore, had 'no leader, although it is incontestable that Grey holds the game in his own hands, and that no Ministry could just now be formed without him being its head.' ${ }^{2}$ Macandrew was eventually replaced in July 1882 as Leader of the Opposition by his long-term friend and ally William Montgomery, the Member for Akaroa. ${ }^{3}$ Criticism of Macandrew's leadership should be treated cautiously: he survived as the Liberals' leader for almost three years and continued to be viewed as a contender for premier-a columnist joked in 1883 about the discomfort generated when Grey, Macandrew and Montgomery arrived simultaneously at the door labelled 'Leader of the Opposition' in the new Parliament building. ${ }^{4}$ It may not have been a desirable position but Macandrew kept the Liberal flag flying in trying times.

In opposition, Macandrew regularly aired his complaint about Atkinson's calculation of the public works expenditure during his administration. Atkinson presented the full cost of the works which included expenses incurred by other portfolios while Macandrew denied his responsibility for these costs. ${ }^{5}$ Listeners would have easily

\footnotetext{
${ }^{1}$ WCT, 4 July 1882.

${ }^{2} S T, 31$ July 1882.

${ }^{3}$ William Montgomery, 1821-1914, Christchurch merchant, runholder. Member Canterbury PC 1866-70, 1873-76, Canterbury Executive Council 1866-69, 1874-75, MHR 1874-87, Colonial Secretary (Stout Ministry) 1884, Member of Executive Council (Seddon Ministry) 1893-95, MLC 1892-1907.

${ }^{4}$ Waikato Times, 19 June 1883.

${ }^{5} \mathrm{OW}, 29$ May 1880.
} 
identified Macandrew's self-justifying behaviour and the extravagance of the Grey Ministry-his protests did nothing to enhance his reputation. Indeed, Macandrew continued to be committed to borrowing to build and soon after losing power, he claimed that 'there is not the slightest doubt, moreover, that with those five millions [a Grey loan that was blocked by Parliament] we could have carried out the whole of the proposals submitted in the Public Works Statement of 1878, and I see no difficulty whatever in the way of the present Government doing it. ${ }^{6}$ Although Macandrew espoused frugality in many areas he continued to promote his railway building programme and despite the faltering economy and the downturn in railway revenue, he wanted Hall's Government to maintain railway investment at the same rate as the Grey Government had done. He also abhorred money sitting unused and suggested 'surely we could not do better, as reasonable men, than to devote a portion of this money, while it is lying idle in the bank, towards the finishing of these railways. That is the practical, common-sense view I take of the matter., ${ }^{7}$ Small wonder that his views on financing were often misunderstood and invited attack: his views were too unconventional and thus suspect to most people.

In an address to his Port Chalmers constituents in 1880, he referred again to a colonial currency, being reported as 'Mr. Macandrew, again, is understood to have some nostrum or another for the manufacture of wealth as fast as greenbacks can be turned out of our Government printing office. ${ }^{8}$ Two years later, in a further attack on his leadership, his proposition was decried more strongly. His speeches 'showed him too plainly to be still the reckless and speculative visionary as of old' and worse still, it was reported that 'Mr. Macandrew opined that a bale of paper and a printing press were all the colony neededexcepting perhaps a little ink-to overcome any possible financial difficulties, by the wholesale issue of paper money. ${ }^{9}$ Macandrew later denied he had made the comment and asked 'Why that phrase should be associated with my name I confess I do not know; it is not a phrase ever made use of by me' but the mockery was accepted as fact and the label stuck. $^{10}$

Macandrew continued to promote a liberal programme which included a fairer distribution of the tax burden. In a want-of-confidence speech in June 1880, one of the few times where Macandrew spoke at length as Leader of the Opposition, he made his position

\footnotetext{
${ }^{6}$ NZPD, Vol. 34, 12 December 1879, p. 902.

${ }^{7}$ Ibid., 17 December 1879, p. 1041.

${ }^{8}$ Press, 25 May 1880.

${ }^{9} E P, 13$ March 1882.

${ }^{10} \mathrm{OW}, 31$ May 1884.
} 
on governance and taxation clear: 'I quite agree as to the expediency of changing the incidence of taxation, so as to distribute it more equitably, but I can be no party to increasing the aggregate of the present taxation upon the country...My idea is that this Legislature should leave the localities to tax themselves for all their local requirements ${ }^{11}$ He acknowledged the difficulties in governing the country faced by any ministry in the current economic climate and that his party probably did not want to hold power at that time. Then in a statement reminiscent of Atkinson's call for a 'political rest' he asserted that 'the Opposition, the Liberal party, or whatever it may be called, is not bidding for office now... The voice of the country, I have no doubt, will in due time demand that we shall make the sacrifice of taking the helm-for I consider it a very great sacrifice under any circumstances, especially if a man has not got his home in Wellington.' This was scarcely the fighting talk voters eager to unseat Hall wanted to hear. His major thrust was a plea for more immigrants 'I take it that immigration is the life and soul of the country. We want mouths to feed.' One journalist's blunt judgment probably represented a widely-held view: 'The speech was not brilliant nor very effective.' 12

In May 1881 Macandrew announced a nine-point legislative programme which included promises to complete his 1878 railway policy; repeal the property tax; resume immigration; reduce education spending by lifting the school-starting age and increased local control and levies; reform the law courts; establish a direct steamer communication with England; readjust parliamentary representation; return $20 \%$ of the land fund to local bodies and finally, his old favourite 'transfer of such business to local bodies, as nearly as may be analogous to Provincial councils as they were intended to be. ${ }^{13}$ Most of these points were adopted the next year as a 'Liberal Political Programme for New Zealand' which retained a property tax and proposed that the Legislative Council be partly elected by local bodies. ${ }^{14}$

Insular Separation, code for provincialism, was one of Macandrew's continuing passions and the country was probably not surprised when he resurrected his idée fixe in October 1881 and released an Insular Manifesto which included twelve resolutions. He suggested that each island revert to provincial status, elect a president and establish a legislature which would be responsible for all laws with twelve exceptions which would be

\footnotetext{
${ }^{11}$ NZPD, Vol. 35, 24 June 1880, pp. 489-94.

${ }^{12}$ Auckland Star, 25 June 1880.

${ }^{13}$ Clutha Leader, 27 May 1881.

${ }^{14}$ The Thames Advertiser, 10 May 1882.
} 
the responsibility of the General Assembly-it would have limited powers of taxation. ${ }^{15}$ Older settlers would have recognised the modified Clause 19 of the Constitution Act 1852 although Macandrew did not acknowledge his source. ${ }^{16}$ His proposal was dismissed, typically, as 'more pretentious but less efficient' than existing plans to devolve powers to the counties. ${ }^{17}$ In his 1885 constituency report he returned to his concerns about the imbalance of power between central and local governments, stating 'I do not think, however, that there can be really good government in New Zealand under any set of men-even were they angels from Heaven, so long as Centralism, not content with confining itself to its proper sphere, insists upon exercising all the functions of localism as well. ${ }^{18}$ Later that year he moved that a Royal Commission be established to consider turning the two islands into separate provinces but members showed their lack of interest by dismissing it on a voice vote. Members may have agreed with him about the imbalance of power but they were not prepared to return to provincialism to solve the problem. ${ }^{19}$

\section{BACKBENCHER}

Although no longer party leader, Macandrew continued to promote immigration and settlement tirelessly. An amendment to the Land Act 1877, passed in 1884 by the reelected Vogel Ministry included a clause instigated by Macandrew which reserved 10,000 acres of land between the Catlins River and Mataura for a special settlement to be offered to crofters in the Highlands and Islands of Scotland. ${ }^{20}$ Each crofter was to be given ten acres of land and could apply to buy a further twenty acres, an offer which reappeared in a more comprehensive Lands Act passed the following year. ${ }^{21}$ Protesters attacked the scheme on the grounds of special treatment, typically asking 'Why, for instance, should the Skye crofters be preferred to the evicted Irish peasants? ${ }^{22}$ Another complained that the crofters would be 'very undesirable immigrants, who would land, if they came, as absolute paupers, and have to be maintained at the public expense until they could make a living for

\footnotetext{
${ }^{15}$ These were customs duties, courts of law, currency, weights and measures, mail, bankruptcy proceedings, navigational aids, shipping dues, native affairs, marriage, criminal law and inheritance laws.

${ }^{16}$ Clutha Leader, 28 October 1881.

${ }^{17} \mathrm{BH}, 4$ November 1881 .

${ }^{18}$ ODT, 30 May 1885.

${ }^{19}$ Ibid., 9 September 1885.

${ }^{20}$ The Land Act 1877 Amendment Act 1884, No. 34, clause 42. Macandrew maintained his ties with Scotland throughout his life and consistently encouraged migration from there to New Zealand, e.g. ODT 24 September 1884: 'Mr Macandrew has a plan by which he proposes not only to relieve New Zealand of unemployed, but also to alleviate the distress of the Highland crofters, of whose hardships so much has recently been said in the Home newspapers.'

${ }^{21}$ The Land Act, 1885, No. 56, clause 165.

${ }^{22}$ Nelson Evening Mail, 12 February 1885.
} 
themselves. ${ }^{23}$ Macandrew justified this project in a letter to London-based George Vesey Stewart, later published in The Times, in which he declared that 'my sole desire is to be instrumental in transplanting as many of my fellow-countrymen as may be from poverty and serfdom to independence and plenty. ${ }^{24}$ This was despite the abject failure of settlements he had promoted for Scottish migrants in remotest Otago: at Jamestown on Martins Bay in Southern Westland and Cromarty in Fiordland's Preservation Inlet in 1869, and Port William on Stewart Island in 1872 where Shetland fishing families endured for only eighteen months. Macandrew's optimism continued to blind him to the realities of poor soil, a challenging climate, remote location and distant markets. Fortunately for the prospective settlers, a lack of enthusiasm and funds in Great Britain ensured the scheme died before birth.

\section{Minister OF THE CroWn Again 1884}

Julius Vogel made a brief visit to economically stagnant New Zealand in December 1882, and was welcomed enthusiastically as 'the man who had once brought prosperity to the country and whose policies might work again. ${ }^{25}$ Macandrew lionised him at a Dunedin banquet where they resumed their friendship: here he took passing credit for Vogel's successes, and announced 'Gentlemen, as a statesman Sir Julius Vogel may be said to have matriculated in Otago, and therefore Otago is entitled to regard him as one of her sons, and as such to feel proud of, and to rejoice at, any distinction that he may have acquired since he went out from among us, some 13 years ago now. ${ }^{26}$

When he next returned to New Zealand in April 1884, Vogel spent two months convalescing in Dunedin and there decided to stand for Parliament in the election scheduled for July, doubtless encouraged by Larnach and Macandrew: Ashburton voters returned him. Stout successfully challenged Atkinson for the Premiership and his Cabinet announced on 16 August included the unlikely combination of Ballance, Macandrew and Vogel. The Timaru Herald confirmed that Macandrew was unforgiven in many quarters and described this Ministry in scathing terms as 'the dullest and most ponderous thing of the kind that could well have been put together' while Stout was excoriated because 'he has introduced to us Mr. Macandrew [who] belongs to a prehistoric generation of New Zealand politicians, and to present him as a member of the powerful, vigorous, enlightened

${ }^{23} T T, 22$ September 1886.

${ }^{24}$ The Times, 9 September 1886.

${ }^{25}$ Dalziel, p. 245.

${ }^{26} \mathrm{OW}, 23$ December 1882. 
Ministry who are to give the Colony new life and a fresh impulse towards prosperity is like putting a fossil megatherium in harness to help to perform a fast coach journey. ${ }^{27}$ The New Zealand Herald resurrected Macandrew's transgressions and considered he 'goes far beyond even Sir Julius Vogel in his enthusiasm for getting into debt, and would create wealth with a printing press and a bale of paper. ${ }^{28}$ Macandrew was appointed Minister of Lands and Immigration, and Minister of Mines.

He had not expected to fill ministerial office again and he was pessimistic about his survival in office. In a letter to Mabel he reflected on the uncertain times: 'I was constrained by my friends very much against my will to form the New Government, knowing well all the time it was not likely to stand,- - as to this, my prognostications proved true and we now hold office only until our successors are appointed. When that may be it is hard to say - as things are in a very unsettled condition and there may probably be several changes before any permanent Govt can be formed. I am being strongly urged to join another Government. I think however that I shall keep out of it and prefer to spend my time at home during the recess. ${ }^{29}$ Stout's Ministry survived just twelve days-its preponderance of South Islanders cost it support. Ministers resigned on 28 August 1884 and Macandrew withdrew. A typical nineteenth-century shuffle followed and Atkinson resumed power for seven days but as he was unable to establish a viable government, Stout and Vogel resumed command on 3 September and governed for the next three years. Their restructured Ministry included, ironically, Macandrew's brother-inlaw, his sometime political rival William Reynolds, and William Larnach. Macandrew had held executive office for the last time. Stout considered appointing him Agent-General as a reward, and wrote to Vogel in December that 'The more I see of Macandrew's desire for the good of the colony, his desire for [?], his fairness \& his unselfishness I must say I feel unable to express my appreciation of his conduct. It is our duty not to forget him. We have none so loyal. ${ }^{30}$ Nothing came of this proposal.

\section{FINAL YEARS}

Macandrew promoted an increasingly liberal variety of causes in his last years in Parliament, having adopted the policies of colleagues such as Ballance, Stout and Vogel. He was a lifelong advocate of intensive land settlement - in 1855 he had suggested that the

\footnotetext{
${ }^{27}$ Timaru Herald, 14 August 1884.

${ }^{28}$ Auckland Herald quoted in ODT, 16 August 1884.

${ }^{29}$ Letter: James Macandrew to Mabel Macandrew, 23 August 1884, KWMSS.

${ }^{30}$ Letter: Stout/Vogel, 15 December 1884, quoted in Blackstock, p. 361.
} 
state make loans to settlers to facilitate their purchase of land - a concept he resurrected in the election campaign of $1884 .{ }^{31}$ Now he proposed the establishment of a State Bank 'whose sole business it would be to make advances upon land at a low rate of interest...any person should be entitled as a matter of right - not of favor - to produce certificate of title under the land Transfer Act, together with certificate of value under the Property Assessment Act, and then and there, without the intervention of any third party, obtain advances not exceeding a certain proportion of the assessed value, which would be fixed by the Legislature at such a rate as would leave margin sufficient to cover contingencies. ${ }^{, 32}$ He was snubbed - the country was still not ready for this radical concept.

In the 1884 Session, Macandrew's suggestion of a Royal Commission to investigate changes to the currency law and the establishment of 'a Government land bank' similar to one used by the Government of India, was promptly dismissed by Treasurer Vogel. ${ }^{33}$ But in 1885 Macandrew's perseverance resulted in the appointment of a Select Committee, which he chaired, to investigate state loans to settlers. It recommended 'that the public credit of New Zealand might with advantage be applied towards enabling settlers, on the security of their land, to acquire advances at a comparatively low rate of interest. ${ }^{34}$ Loans would be administered by the Land Transfer Office and payment would be in interest-bearing New Zealand Government debentures which could be used as currency and the Committee proposed that a Bill incorporating its recommendations be prepared for the next session.

Vogel would not adopt the Committee's submission so Macandrew prepared his own Public Advances on Land Bill that summer. When moving its second reading in July 1886 , he claimed that land is the only security that offers a perfect guarantee to the State and that 'whatever tends to make the pastoral and agricultural industries more profitable, whatever tends to the beneficial occupation of the country- that is a benefit to every class in the community. ${ }^{35}$ Macandrew claimed it was the duty of the State to use its credit to make loans to landowners at rates lower than commercially obtainable and the Bill would allow advances upon the security of the land at moderate terms to be made through the Land Transfer Department - he had by now dispensed with a State bank. The outraged reaction of an editor who spluttered 'the absurdity of the whole business is so manifest, so

\footnotetext{
${ }^{31}$ V. and P., OPC, Session II, 7 May 1855, p. 52.

${ }^{32}$ Wanganui Herald, 29 July 1884.

${ }^{33}$ NZPD, Vol. 50, 28 October 1884, p. 147.

${ }^{34}$ AJHR, 1885, I-6, p. 1, Report of the Advances on Land Committee.

${ }^{35}$ NZPD, Vol. 55, 8 July 1886, p. 404-429.
} 
ludicrous, that discussing it would be thought a waste of time' could not deny that a majority of Parliamentarians - thirty-one to eighteen-including Ballance, Grey, Larnach and the later Liberal Minister of Lands John McKenzie, supported Macandrew's scheme although Richard Seddon opposed it, and gave the Bill a second reading. ${ }^{36}$ Their votes point to the Liberals' ongoing re-evaluation of the role of government and their acceptance of state intervention in the economy and reflect Macandrew's shift in values, from a conservative economic position to populist liberalism. His Bill, which might have progressed the next year, was interrupted by the end of the session, then by Macandrew's death in early 1887, which left it sponsorless. His proposal would bear fruit when Joseph Ward's Government Advances to Settlers Act, which incorporated Macandrew's suggestions, was passed in 1894. Michael Bassett identifies this period as the one where: 'previously the state had sold or leased land to settlers. Now it took upon itself the task of acting as broker between overseas lenders and domestic borrowers. ${ }^{37}$

The unemployed concerned him increasingly, and his solutions for the widespread poverty in the country grew more radical as the depression deepened: he considered that 'were I a dictator, I should drive the unemployed from the towns and compel them to support themselves upon land of their own, for which they should pay nothing to the State. ${ }^{38}$ As usual, he had a solution for the problem but, unfortunately, the arrival of Black Rod with the prorogation message meant his six propositions were not discussed. ${ }^{39}$ They included a recommendation 'that the granting of an adequate area of land, on the sole condition of beneficial occupation, to every man who is able and willing to work would to a large extent reduce the number of unemployed.' Blocks of land would be administered by local government bodies 'to be by them assigned, in small allotments, to the ablebodied poor,' which would 'greatly tend to diminish and ultimately all but extirpate pauperism.' This recommendation was an extension of the Village Settlement clauses of the Lands Act 1877 Amendment Act 1879, which had enabled working-class men and their families to leave the towns and get onto the land: it had encouraged groups of prospective farmers to each buy up to fifty acres of land on deferred payment and form a community. ${ }^{40}$ In 1886, he also recommended the appointment of 'a separate Minister of the Crown (whose time and attention) might be devoted exclusively to land administration in each

\footnotetext{
${ }^{36}$ Colonist, 13 September 1886.

${ }^{37}$ Michael Bassett, Sir Joseph Ward: A Political Biography, Auckland, Auckland University Press, 1993 , p. 53.

${ }^{38}$ ODT, 27 May 1884.

${ }^{39}$ NZPD, Vol. 56, 18 August 1886, p. 865-866.

${ }^{40}$ Land Act 1877 Amendment Act 1879, No. 21; McIvor, p. 98.
} 
Island.' Macandrew's panacea for all economic ills-land-was still available in large quantities during his lifetime but it is likely that, even if it had not been available, he would have supported state support for the unemployed.

By the age of 65 Macandrew was wearying and in May 1885 he informed his constituents that Parliamentary procedure was responsible for his intended retirement at the end of the session because 'the absurd and unnatural system which the House has adopted of turning night into day, and of continuing its sittings long into the small hours in the morning, which has become the rule instead of the exception, does not suit my constitution.' ${ }^{41}$ In 1884 he had persuaded the Committee on Standing Orders to recommend that House sitting hours should extend from 10:30 am to 5:30 pm with committees sitting in the evening, but his fellow parliamentarians declined to back him then, or in $1885 .{ }^{42}$ Depression brought about by pain and the cost of supporting a large family may have affected him as he admitted to his fourth son, Hunter, that 'I have been very much on my beam ends since coming here from a pain in one of my knees... and the prospect of increased taxation does not render the prospect brighter. I wish I had taken possession of Cod Fish Island with its 3000 acres which I could have had for $£ 500$ and $£ 25$ a year rent. It would have been a standby run which would have enabled the family to live in comparative affluence and independence. ${ }^{43}$ His infirmity may have triggered a rumour that he was to be appointed to the Legislative Council, which failed to eventuate, but he remained sufficiently popular for an editor to write: 'it is hoped that notwithstanding his rather failing health and well-known objections to late sittings, he may for some time yet continue to hold the position of Father of the House of Representatives. ${ }^{44}$

His long service to local and colonial government was recognised in several ways. On 25 November 1885 the University of Otago Council accepted a full-length portrait of Macandrew by Kate Sperry. ${ }^{45}$ A similar portrait by the same artist was hung after his death in the Parliamentary library but was destroyed in the fire of 11 December $1907 .{ }^{46} \mathrm{He}$ was elected as President at the inaugural meeting in May 1884 of the Otago Early History

\footnotetext{
${ }^{41}$ ODT, 30 May 1885.

42 Journals of the House of Representatives, 25 June 1885, p. 42-3.

${ }^{43}$ Letter: James Macandrew to Hunter Macandrew, 22 August 1885, KWMSS.

${ }^{44} \mathrm{BH}, 22$ December 1885.

45 ODT, 26 November 1885. The portrait hangs in the University's Clock Tower Building.

${ }^{46}$ Star, 10 May 1888.
} 
Society, later the Otago Early Settlers Association. ${ }^{47} \mathrm{He}$ was the only serving Parliamentary survivor of the first Assembly and now considered an Old Identity.

His longevity gained him special treatment. One newspaper announced that ' $\mathrm{Mr}$. James Macandrew is a privileged person in the House. He would be the last man to make any pretension to eloquence, yet he is always listened to. ${ }^{48}$ The editor was amazed that Macandrew's Public Advances on Land Bill had been supported by such a generous majority because 'the first Stout-Vogel combination included him and more than anything else that brought about its speedy defeat. It is not on the ground of his long experience so much as from a vague superstition that he is a practical man, a title that once acquired, no matter how, is a sufficient cloak for the wildest vagaries.' Macandrew remained a force in public life although many critics were distracted by his reputation and did not appreciate his originality.

Then suddenly he was gone, fatally injured on 23 February 1887 at the age of 67 , in the driveway of his Macandrew Bay home when his carriage was overturned by a bolting horse. ${ }^{49}$ On 28 February his funeral at Macandrew Bay was attended by 1,500 people. Premier Stout, ex-Premier Hall, five MLCs and fifteen MHRs were joined by the huge crowd of mourners who travelled by boat across the inner Otago Harbour. The city closed while a service was held at his home then 'the coffin was borne by the mayor and councillors of Port Chalmers and settlers on the Peninsula to the private cemetery on the top of the hill at the back of the residence, where Mrs. Macandrew was buried some 12 years since. $^{, 50}$

Most obituaries were effusive. They ignored his faults, laboured his virtues, especially his personal qualities, and were circumspect about the events which saw him imprisoned. His commitment to Otago featured in them all: 'Otago had no truer friend; New Zealand no more faithful servant, and if he seemed to place the Province first and the Colony second, it could scarcely be his fault, for his whole heart and soul were bound up in the place and people where, and amongst whom, he passed the greatest portion of his useful and vigorous existence. ${ }^{51}$ His energy and unceasing activity was noted: 'He never paused nor rested satisfied with what was already done. Every achievement was only a

\footnotetext{
${ }^{47}$ EP, 17 May 1884.

${ }^{48}$ Colonist, 13 September 1886.

${ }^{49}$ Macandrew Family Bible, held by Otago Settlers Museum, Dunedin, records his age at death as 68.

${ }^{50} \mathrm{OW}, 4$ March 1887.

${ }^{51}$ BH, 1 March 1887.
} 
stepping stone to him. ${ }^{52}$ The personal qualities which helped him convince so many doubters were recalled: 'Members felt that when he addressed them, whether the views he advocated met with their approval or not, he was honest in their advocacy; and so they often listened without impatience to his exposition of theories on many subjects which were far from being in accord with their own views and opinions. Much of the kindly feeling evinced towards him was also due to his unfailing geniality, and to the remarkable absence of satirical comment and of all bitterness, by which his speeches were characterised. ${ }^{53}$ The Otago Daily Times was the exception and emphasized his flaws but they also acknowledged his redeeming qualities, editorialising: 'Mr. Macandrew's public character had grave defects. He never could understand the importance of details, and his absolute lack of what is termed business capacity led him into errors which made him a mischievous administrator, and would have terminated the political career of any ordinary man. But James Macandrew was no ordinary man...He has long been the David to the people of Otago, the man after their own heart, in spite of faults which it is impossible to defend or even entirely to forget. ${ }^{54}$

Distance lent enchantment, and he was acknowledged by an Aberdeen newspaper which wrote that 'It is in great part due to his indomitable perseverance and fertile brain that New Zealand is so well supplied with railways...As a statesman and a public benefactor, Mr. Macandrew had few equals in the colony, and his loss will be mourned throughout its length and breadth. ${ }^{55}$ The Times of London paraphrased the Aberdeen entry to a muted one hundred and twenty-five words, and concluded that: 'Both as a statesman and a public benefactor the deceased was held in high esteem through the colony. ${ }^{56}$ The ambitious young settler who sailed from London on 7 September 1850 would have been satisfied with this epitaph and, doubtless, would have taken it as his due.

\section{Conclusion}

Was James Macandrew 'Slippery Jim' or 'A Leader Staunch and True'? Contemporary descriptions of him were shaped by the social rank, economic standing and political views of the commentator. ${ }^{57}$ He clashed with social superiors such as Governor

\footnotetext{
${ }^{52}$ Mataura Ensign, 1 March 1887.

${ }^{53} \mathrm{OW}, 4$ March 1887.

${ }^{54}$ ODT, 25 February, 1887.

${ }^{55}$ Aberdeen Weekly Journal, 5 April 1887.

${ }^{56}$ The Times, 15 April 1887.

${ }^{57}$ As only men voted, the politicians and most of the newspaper writers were men, so it has been impossible to find a woman's view of him.
} 
Grey and Henry Valpy, he vied with equals like William Cutten and John Jones: while he was seen as 'silvery, cunning, and not over-scrupulous' by a contemporary, he was also considered an esteemed friend of the working class. ${ }^{58}$ In one election, it was claimed, his support came from 'nearly all of the trading classes and a large proportion of the artisans of Dunedin. ${ }^{59}$ His appeal to all Otago voters is demonstrated by his seventeen successes in the nineteen elections he contested in his lifetime. He won three elections to the Otago Provincial Council and ten of his eleven Parliamentary races. He won four of the five elections he contested for Superintendent and came a comfortable second from his prison cell in the other. In Parliament he led the opposition, scarcely a sinecure, for over three years.

Many people thought that his empathy offset his character flaws. A colleague wrote: 'His ideas were eminently visionary, and his speeches were curiously illogical and unconvincing. Yet he could carry a bill or a motion which nobody else in the House could have carried. And all because his nature was extraordinarily sympathetic. He could get men to vote with him against their judgment, simply by enlisting their feelings. ${ }^{60}$ People identified with his faith which was described by the Rev. Alexander Greig: 'Mr. Macandrew was a truly religious man - one who feared God, and who respected and honoured every ordinance of God. He was one who did not act from impulse, but from principle, and who was never ashamed to show where his heart was. He was not given to speak of his faith, or his feelings, or his hopes, but he was constantly giving evidence that all of these were of the right kind. ${ }^{61}$

Macandrew's life was not based on complex beliefs. He identified closely with the principles of the Otago Settlement: 'Education and religion, agriculture and commerce' were his drivers, and they evolved into 'his political creed [which] was encapsulated at his death in four words, 'roads, population, bridges, capital. ${ }^{, 62} \mathrm{He}$ was an early adopter of ideas who too often outpaced his colleagues with his visions of the future - they wanted to know all the implications of his schemes before backing him while he wanted commitment to advance an idea. It was said of him that 'Lacking perhaps in administrative power, and characterised by a too hopeful disposition, he propounded much that was at the

\footnotetext{
${ }^{58}$ Menzies, Journal.

${ }^{59}$ NOT, 26 February 1867.

${ }^{60}$ ST, 3 March 1887.

${ }^{61}$ The N.Z. Presbyterian, 1 April 1887, p. 190-1. Greig was the Minister of Macandrew's Otago Peninsula Parish from 1868-1904.

${ }^{62}$ Bay of Plenty Times, 28 May 1887.
} 
time and in the circumstances of the Colony too far in advance of the Colony's needs and its means; but which at length, through his perseverance and the onward march of events, became, however, an accomplished fact. ${ }^{63}$ In particular, he was an early adaptor of technology to improve the quality of life for everyone and when his fellows failed to agree with him, his impatience surfaced.

In New Zealand Macandrew built much and his projects were his memorials. As Superintendent he was the instigator of the Normal Training School and School of Art, the Benevolent Institution, the Caversham Industrial School, the High School and the Otago University. He was one of the prime movers in the construction of the Oamaru breakwater, the Dunedin and Port Chalmers and Clutha railways, and many other public works. He was principally responsible for the building of the Otago graving dock at Port Chalmers. ${ }^{64}$ As a Minister, his monument is the Public Works Statement of 1878 with its commitment to a national railway system for the colony while numerous bridges, roads and wharves are part of his legacy.

Macandrew shaped events - from the time he arrived in New Zealand, he used his knowledge and skills to improve conditions for people in all walks of life. His Presbyterian, utilitarian beliefs drove him to ensure that all citizens, regardless of their race, and creed, would have the best physical, intellectual and emotional conditions to enjoy a fulfilling life: his legacy was the extensive array of educational institutions in Otago. He was the very model of the explosive coloniser, an exploiter of resources, a fervent supporter of intensive settlement and easy access to land, prepared to use the state's resources if required. He came early to believe in State involvement in the development of the Colony, knowing that only the State, with the resources available to it, raised by taxation or by borrowing, could build the infrastructure for a modern nation. It is likely that his economic views evolved as the financial position of the colony improved. A poor and isolated settlement like Dunedin had no communal resources to support the needy and every man had to pay his own way but as the wealth of the nation materialised, he became aware that the state could afford to support the destitute. If the state could invest in infrastructure, then the state could invest in its people. With the demise of the provinces, and the coming of the Long Depression, his commitment to individual responsibility faded as settlers turned to an activist State for survival: it was in this period that his 'pragmatic interventionism' flowered fully. ${ }^{65}$

\footnotetext{
${ }^{63}$ The Clutha Leader, 4 March 1887.

${ }^{64} S T, 26$ February 1887.

${ }^{65}$ Michael Bassett, The State in New Zealand: 1840-1984, Auckland, Auckland University Press, 1998, p. 10.
} 
Typically, providing access to education for all was a mission which engaged him throughout his life, a mission that emerged from his own upbringing.

His allegiance to provincial government was constant throughout his life. Although not committed to a specific number of provinces in New Zealand, it was his belief in the distinct allocation of responsibilities between central and local bodies for which he is best remembered. He believed that citizens would be loyal to their own locality which had to be sufficiently large to provide efficiently the services required to make a community function well — education, law and order, public works — while central government took responsibility for matters that affected the entire country. He observed accurately that 'The Provincial Councils, which some among us nowadays in their ignorance affect to despise, were no shams. What would the people of Ireland and Scotland give for such Councils? ${ }^{66}$ The current reorganisation of local government in New Zealand supports his view.

While Morrell provides a comprehensive and compelling set of explanations for the demise of the provinces, he does not acknowledge the influence of personal relationships on the timing and the outcomes of the debates. ${ }^{67}$ If Macandrew's passionate defence of the provinces had not so infuriated Vogel and led to a sequence of widely published recriminations, abolition might not have been absolute. ${ }^{68}$ If Macandrew had been less reactionary and had supported the passage of the New Zealand Forests Bill in 1874, Vogel might have been restrained to transform the North and the Middle Islands into a province each. But Macandrew's barbs hit home and Vogel commented: 'As you have twice referred to me personally, I may be allowed to say that I continued to aid the Provinces, and to believe they might be enabled to survive, long after that belief was dead in the minds of some of the most acute men in New Zealand. No Province has, in my opinion, more contributed to make Abolition necessary than has Otago- for it has refused to accept any limit to its desire to exp end money. ${ }^{69}$ Alternatively, a less obstinate Macandrew might have ensured that the provinces survived as the units of local government, based on the English counties as intended by the drafters of the Constitution Act of 1852.

By the 1880s, Vogel's prediction that 'when the iron horses ran through the two Islands, then they would have no more need of provinces' had eventuated and political

\footnotetext{
${ }^{66}$ ODT, 30 May 1885.

${ }^{67}$ See p. 138, fn. 166.

${ }^{68}$ AJHR, 1876, A-4. See p. 167, fn. 126.

${ }^{69}$ Ibid., Letter: Vogel/Macandrew, 3 May 1876, p. 12.
} 
stability in New Zealand was secure. ${ }^{70}$ With a responsible, representative, central government and the country at peace, the rapid development of infrastructure unified the country. It was now that 'the telegraph, the railways, shipping and other enterprises which were national rather than local all transformed New Zealand, all led to a sense of 'oneness', to a recognisable and recognised national identity. ${ }^{71}$ In addition, the Education Act 1877 created a nationalising movement by replacing 'provincial variety with a colony-wide system of primary education, thus reducing if not eliminating regional disparity. ${ }^{, 72}$ It is in this period that Macandrew articulated his concern for all New Zealanders and launched his suggestions for economic deliverance, including state loans for settlers, crofter immigration and free land for the unemployed. Although recognised as the foremost promoter of Otago, Macandrew's parliamentary record demonstrates that he always had the interests of the entire country at heart.

Scots were a large and disproportionately successful minority of New Zealand settlers, and Macandrew was prominent among them. His meritocratic world-view underlay the enormous amount of energy and time he invested in education at all levels. When he arrived in Otago, his status and his commitment to the Bible, family and Scottish lore made him immediately acceptable, and it was a foregone conclusion that he would represent the settlers at provincial or colonial levels or both, at his own cost: he proceeded to take on virtually all the governance roles available to him.

His flaws emerged early in Otago where he earned the label of 'Slippery Jim.' His talents made him an organiser and a leader to whom the settlers looked for guidance. His knowledge of parliamentary procedure, his intelligence and his people skills made him a valuable if contrarian member in the fledgling Provincial Council and he ultimately occupied most of the leadership positions in that Council-Member, Executive Councillor, Treasurer, Speaker and Superintendent. Yet he eventually treated his positions with contempt and used them as a means of salvaging his personal financial position. The uncertain economy with its booms and busts could be considered responsible for his bankruptcy but there were other settlers who made and retained fortunes, who avoided the risky investments that ruined him.

\footnotetext{
${ }^{70}$ Ibid., 26 July 1866, p. 824.

${ }^{71}$ Ron Palenski, The Making of New Zealanders, Auckland, Auckland University Press, 2012, p. 18.

72 Jeanine Graham, 'Settler Society', in Geoffrey Rice, ed., Oxford History of New Zealand. $2^{\text {nd }}$ ed., Auckland, Oxford University Press, p. 132.
} 
He used his assets, his wife's inheritance, money held in trust for other colonists and public money to rescue his unviable business ventures. In 1860 Macandrew lost $£ 41,900$ and was later declared bankrupt. His political activism and his impatience with planning and accounting led to the collapse of his world which he never attempted to replicate. He did not venture into the business world again but his political life suffered from the same disregard for details and an obsession with promoting major projects which he failed to supervise effectively. He was too independent and despite his persuasiveness, he was often unable to garner support for his major goals: the provinces were abolished despite his desperate opposition and his tenure as a Minister ended in disarray. As a leader he was stirring, resolute and energetic but ultimately he trusted too much and was an unsuccessful manager of men.

Responses to his behaviour went beyond attacks by parliamentarians and reporters. A considerable amount of the Colony's time and resources were expended to prevent repetition of his behaviour, which is ironic, given his intermittent concern with public expenditure and his quest for retrenchment. By 1867 he had precipitated three Otago Provincial Council Select Committees, two enquiries by the Auditor-General, a complete Appendix to the Journals of the House of Representatives, and six Acts of Parliament. 
When he was a Minister he precipitated a further two Select Committees and in 1880, two Royal Commissions investigated his Ministerial performance. ${ }^{73}$

His career earned him few accolades. He earned no title while colleagues were knighted-Wilson in 1872, Bell in 1873, Vogel and McLean in 1874, Fitzherbert in 1877, Stafford and Fox in 1879, O'Rorke in 1880, Hall and Whitmore in 1882, Whitaker in 1884, Stout in 1886, Atkinson in 1888. Admittedly no Superintendent was ever knighted for services to his province - but Ministers were. By a misfortune of timing he did not earn the right to retain the title Honorable, as did his Otago colleagues who completed their three years of cabinet service-Vogel in 1871, Reynolds in 1876, Oliver in 1884, Larnach, Richardson and Stout in 1887. The collapse of his business empire marked the end of his travel abroad: he never returned to Britain, either as a private citizen or in a public role. He was not wealthy when he died but was modestly comfortable, leaving his farm to be divided amongst his sons, his house for his daughters and an estate worth $£ 1485$. 1. $2^{\mathrm{d}}{ }^{74}$ His nine living children all survived into the next century, none of them engaged in political activities and none of his daughters married.

73 The Otago Provincial Council appointed three Select Committees to investigate aspects of Macandrew's behaviour:

V. and P., OPC, Session VI, 16 November 1857, Appendix, Report, Select Committee on the State of the Land Office;

V. and P., OPC, Session VII, 11 November 1858, Appendix, Report, Select Committee on Immigration Correspondence;

V. and P., OPC, Session XI, 18 December 1860, Appendix, Report, Select Committee on the State of the Public Accounts, Public funds, \&c.

AJHR, 1867, D-1. Papers Relative to the case of Mr. Macandrew contains two reports by the Auditor General:

The Report of the Commissioner Appointed to Examine the Public Accounts of the Province of Otago, 1861, pp. 17-21;

Letter: Dr C. Knight to E.W. Stafford, 18 March 1867 printed as Enclosure 2 to Paper 19, p. 41.

Macandrew's behaviour precipitated six Acts of Parliament:

The Superintendents' Elections Disallowance Signification Act 1866, No. 58, was passed to give the Governor sole right to dismiss a Superintendent-he no longer required a petition from a Provincial Council to initiate a dismissal; The next four fell out of the goldfield delegation episode.

Gold Fields Act Amendment Act 1867, No. 68;

Gold Fields Act Amendment Act 1867 (No. 2) 1867, No. 69;

The Otago Gold Fields Judicial Officers Act 1867, No. 70;

Governor's Delegations Act 1867, No. 74.

The Public Offenders Disqualification Act, 1867, No. 49, prevented felons and bankrupts taking elective office.

AJHR, 1879 contains the reports of two Select Committees appointed to investigate a purportedly altered map:

I-2. Report of the Railway Map Inquiry Committee, reported back 23 July 1879.

I-2A. Report of the Railway Map Inquiry Committee (Revived), reported back 8 August 1879.

AJHR, 1880 contains the reports of two Royal Commission which reported on his performance as a Minister: $\mathrm{E}-3$. Report of the Railways Commission;

$\mathrm{H}-2$. Report of the Royal Commission on the Civil Service of New Zealand.

${ }^{74}$ Last Will and Testament of James Macandrew, died 24 February 1887, ANZ, Dunedin, DAAC D239 9074

251 A917 
Today his monuments are few and far-flung and most are insignificant: a statue outside Dunedin's Otago Settlers Museum, the eponymous Bay on the Otago Peninsula where he lived much of his life, a school and a number of streets in Dunedin bear his name although Macandrew St in the inner city has since been renamed Burlington St. There are Macandrew Streets in rural Otago, at Otautau, Milton and Owaka, while the only North Island Macandrew Street is in Woodville. Jamestown is the site of a failed settlement on the shores of Lake McKerrow in Westland and Macandrew Township was gazetted in 1879 near Riversdale in Southland. Symbolically, all traces of the Macandrew Bridge over the Kawerau River at Bannockburn, built in 1878 and rebuilt in 1897, were lost when flooded by Lake Dunstan in $1992 .^{75}$

He was 'a leader staunch and true.' His leadership was inspirational rather than administrative. He enthused with his visions and plans but he was an ineffective delegator, too often trusting unreliable men and neglecting to oversee the execution of his plans. He was impetuous and disregarded details, often relying on inspirational speeches to carry his audiences. He was also the 'slippery Jim' who misused money and misled people. His business dealings turned into a trail of disaster in Dunedin and he was fortunate not to be gaoled for a longer period for fraud. He was a visionary and a liar, he was considerate yet selfish, he was intelligent yet he underestimated the sensibilities of others: ultimately, James Macandrew was a paradox.

${ }^{75} \mathrm{OW}, 10$ August 1878. 


\section{BIBLIOGRAPHY}

PRIMARY SOURCES

\section{$\underline{\text { Manuscripts }}$}

\section{Alexander Turnbull Library, Wellington}

Atkinson, Harry, MS Papers 91.

Ballance, John, MS Papers 25.

Hall, John, MS Papers 1784.

Rolleston, William, MS-77-248-01/4.

Stafford, Edward, MS Papers 2045-2050.

Stout, Robert, MS Papers 40.

Vogel, Julius, MS Papers 2072.

\section{Archives New Zealand, Wellington}

Governors' Papers.

\section{Archives New Zealand, Dunedin}

Macandrew, James/Superintendent correspondence: 'Making Stafford Street passable for winter. He is starting a brick and tile works near the Town Belt', 16 March 1859, Archives New Zealand, Dunedin, AAAC 707 D500 130/c 118.

Last Will and Testament of Eliza Hunter Macandrew: signed 11 December 1874, Archive New Zealand, Dunedin, DAAC D239 23435.

Last Will and Testament of James Macandrew: died 24 February 1887, Archives New Zealand, Dunedin, DAAC D239 9074251 A917

\section{Hocken Library, Dunedin}

Macandrew, James, correspondence with relatives, MS-00111/2.

Minute Book 1851, Otago Settlers’ Association, Hocken Library, MS-0032.

Elder, James Brown, 'Notes for Early History Society of Otago', MS-0043

Cargill, William correspondence: 'Papers relating to the establishment of Otago', MS-0075-0076

Papers of the Otago Association, MS-0077-0078.

Despatches from the New Zealand Company and correspondence with New Zealand agents, MS-0079-0083.

Monson, Henry, Journal, Hocken Library, MS-0088.

Cargill, William, letter book, MS-0095

Reid, Donald, letters, MS-0178.

Depasturage Licenses Applications, Otago, MS-0209/006. 
Cargill, William, correspondence re applications for depasturage licences, MS0211/3.

Macandrew \& Co./Octavious Harwood correspondence and summons over unpaid bills, MS-0438/127 \& 128.

Hector, James/Farmer, James correspondence, MS-0443-3/4-31.

Hocken, Thomas, correspondence, MS-0451/003.

McGlashan, John, correspondence, MS-0463/2-36.

New Zealand Agricultural Company agreement, 14 November 1878, MS-0585.

Macandrew, James, Arithmetic Exercise book, MS-0619.

Cargill, William, 'Receipts for payment in Otago settlement', MS-1751 00.

Terms of Purchase of Land in the Settlement of Otago, June 1847. Hocken Library MSS-Pam-124/2.

Flotsam and Jetsam, Vols. 1-17.

\section{Otago Settlers Museum}

Macandrew, James: 'Address to the People of Otago', pamphlet, 1875.

Macandrew Family Bible.

Menzies, J.A., Dr., Journal.

Minute Book of the James Macandrew testimonial committee 1878.

Richardson, J.C.L. papers.

\section{National Library of Scotland}

Oliver \& Boyd, Booksellers of Edinburgh, and Robert Garden, then Garden \& Macandrew of London, correspondence 1841-1850, National Library of Scotland MSS, Acc 5000/Vols. 201, 203, 204, 205, 206, 207.

\section{Other Manuscripts}

Annual Report of the First Church of Otago for the year ending 31st December 1852, Presbyterian Church Archives, Knox College, Dunedin.

Macandrew Family papers in possession of Kate Wilson, Middlemarch, New Zealand.

Rates book of the Dunedin Town Board (established 1857), Vol. 4/1, held by the Dunedin City Council.

The Minute Book of the Trustees, Dunedin, 1848 to 1867, Trust Fund for Religious and Educational Uses, held at the Office of the Otago Foundation Trust Board, Dunedin.

The Wanderings and Doings of a British Family in England, Scotland, Portugal, Spain and New Zealand, unpublished manuscript history of the Reynolds Family, written by Charles Waddy, Seddon, New Zealand, 2011. 


\section{Newspapers}

Aberdeen Weekly Journal

Ashburton Guardian

Auckland Morning News

Bruce Herald

Clutha Leader

Colonial Journal

Colonist

Daily Free Press

Daily News London

Daily Southern Cross

Evening Post

Glasgow Herald

Grey River Argus

Hawke's Bay Herald

Lyttelton Times

Mataura Ensign

Nelson Examiner and New Zealand Chronicle later Nelson Examiner

Nelson Evening Mail

New Zealand Journal

New Zealand Herald

New Zealand Spectator and Cook's Strait Guardian

North Otago Times

Otago Daily Times

Otago Colonist

Otago Journal.

Otago Witness

Southland Times

Star

Tuapeka Times

The Aberdeen Journal

The Times of London

The New Zealander

Timaru Herald.

Wanganui Herald

Wellington Independent

\section{Official Printed Sources}

Votes and Proceedings of the Otago Provincial Council, 1853-76.

Otago Provincial Government Gazette, 1853-76.

New Zealand Parliamentary Debate, 1854-88.

Journals of the House of Representatives, 1885

Appendices to the Journals of the House of Representatives, 1858-88. 


\section{SECONDARY SOURCES}

\section{$\underline{\text { Books }}$}

Adam, James, Twenty Five Years of Emigrant Life in the South of New Zealand. Edinburgh: Bell and Bradfute, 1876.

Anderson, Robert David, Education and the Scottish People 1750-1918. Oxford: Clarendon Press, 1995.

Arnold, Rollo, The Farthest Promised Land: English villagers, New Zealand immigrants of the 1870s. Wellington: Price Milburn, 1981.

New Zealand's burning: the settler's world in the mid 1880s. Wellington: Victoria University Press, 1994.

Atkinson, Alan, The Europeans in Australia. Vol. 2, Melbourne: Oxford University Press, 2004.

Barr, James, The Old Identities. Dunedin: Mills, Dick \& Co., 1879.

Bassett, Judith, Sir Harry Atkinson: 1831-1892. Auckland: Auckland University Press, 1975.

Bassett, Michael, Sir Joseph Ward: A Political Biography. Auckland: Auckland University Press, 1993.

The State in New Zealand: 1840-1984. Auckland: Auckland University Press, 1998.

Bathgate, Alexander, Colonial Experiences or Sketches of People and Places in the Province of Otago, New Zealand. Glasgow: James Maclehose, 1874.

Picturesque Dunedin. Dunedin: Mills, Dick and Co., 1890.

Belich, James, Making Peoples: A History of the New Zealanders from Polynesian Settlement to the End of the Nineteenth Century. Auckland: Penguin, 1996.

-The New Zealand Wars and the Victorian Interpretation of Racial Conflict. Reprint. Auckland: Penguin, 1998.

Paradise Reforged: A History of the New Zealanders from the 1880s to the Year 2000. Auckland: Allen Lane, 2001.

Replenishing the Earth: The Settler Revolution and the Rise of the Anglo World 1783-1939. Oxford: Oxford University Press, 2009.

Beaglehole, J.C., New Zealand: A Short History. London: George Allen \& Unwin, 1936.

Boast, Richard, Buying the Land, Selling the Land: Governments and Maori Land in the North Island 1865-1921. Wellington: Victoria University Press, 2008.

Bohan, Edmund, Edward Stafford: New Zealand's First Statesman. Christchurch: Hazard Press, 1994.

To Be a Hero: Sir George Grey 1812-1898. Auckland: HarperCollins (New Zealand), 1998. 
_Blest Madman' Fitzgerald of Canterbury. Christchurch: Canterbury University Press, 1998.

Bracken, Thomas, Musings in Maoriland. Dunedin: Arthur T. Keirle, 1890.

Brock, Jeanette M., The Mobile Scot: A Study of Emigration and Migration 18611911. Edinburgh: John Donald, 1999.

Brooking, Tom, 'And Captain Of Their Souls'. Dunedin: Heritage Books, 1984.

Lands for the People? The Highland Clearances and the Colonisation of New Zealand: A Biography of John McKenzie. Dunedin: University of Otago Press, 1996.

Brooking, Tom and Coleman, Jennie, eds., The Heather and the Fern: Scottish Migration \& New Zealand Settlement. Dunedin: University of Otago Press, 2003.

Buchanan, Neil Harkness and Buchanan, Andrew Hamilton, eds., Andrew Buchanan Diaries 1865, 1873. Christchurch: Neil Harkness Buchanan and Andrew Hamilton Buchanan, 1997.

Bueltmann, Tanja, Scottish Ethnicity and the Making of New Zealand Society 1850-1930. Edinburgh: Scottish Historical Review Monographs Series No. 19, Edinburgh University Press, 2011.

Burdon, Richard, The Life and Times of Sir Julius Vogel. Christchurch: The Caxton Press, 1948.

Bush, Graham, Local Government \& Politics in New Zealand. 2nd edn. Auckland: Auckland University Press, 1995.

Butterworth, Susan and Graham, Chips off the Auld Rock: Shetlanders in New Zealand. Wellington: Shetland Society of Wellington, 1997.

Cage, R.A., ed. The Scots Abroad: Labour, Capital, Enterprise, 1750-1914. London: Croom Helm, 1985.

Cameron, George G., The Scots Kirk in London. Oxford: Becket Publications, 1979.

Carrington, C.E., John Robert Godley of Canterbury. Christchurch: Whitcombe \& Tombs, 1950.

Cowan, A.H., Sir Donald Maclean. Dunedin: A.H. \& A.W. Reed, 1940.

Cox, Alfred, Recollections. Christchurch: Whitcombe \& Tombs, 1884.

Curthoys, Ann, Genovese, Ann, Reilly, Alex. Rights and Redemption: History, Law and Indigenous People. Sydney: University of New South Wales Press, 2008.

Cyclopedia of New Zealand, Christchurch: The Cyclopedia Company, 1905.

Dalziel, Raewyn, Julius Vogel: Business politician. Auckland: Auckland University Press, 1986.

Davidoff, Leonore, and Hall, Catherine, Family Fortunes: Men and Women of the English Middle Class, 1780-1850. London: Hutchinson, 1987.

Davidson, William Soltau, William Soltau Davidson 1846-1924 a Sketch of His Life Covering a Period of Fifty-Two Years, 1864-1916, in the Employment 
of the New Zealand and Australian Land Company Limited. Edinburgh: printed for private circulation by Oliver \& Boyd, 1930.

Devine, Tom, The Great Highland Famine: Hunger, Emigration and the Scottish Highlands in the Nineteenth Century. Edinburgh: John Donald, 1988.

Scottish Emigration and Scottish Society: Proceedings of the Scottish Historical Studies Seminar, University of Strathclyde, 1990-91. Edinburgh: John Donald, 1992.

The Scottish Nation: A Modern History, London: Penguin, 1999.

Scotland's Empire: The origins of the Global Diaspora. London: Penguin, 2004.

-To the Ends of the Earth: Scotland's Global Diaspora, 1750-2010. London: Penguin, 2012.

Devine, Tom, ed. Conflict and Stability in Scottish Society 1700-1850: Proceedings of the Scottish Historical Studies Seminar University of Strathclyde 1988-89. Edinburgh: John Donald, 1990.

Devine, Tom and Mitchison, Rosalind, eds. People and Society in Scotland: Volume 1, 1760-1830. Edinburgh: John Donald in association with The Economic and Social History Society of Scotland, 1988.

Donnachie, Ian and Whatley, Christopher, eds. The Manufacture of Scottish History. Edinburgh: Polygon, 1992.

Dumett, R.E., Gentlemanly Capitalism and British Imperialism: The New Debate on Empire. New York: Longman, 1999.

Dunmore, John, Wild Cards: Eccentric Characters from New Zealand's Past. Auckland: New Holland Publishers (NZ), 2006.

Dunn, W.H. \& Richardson, I.L.M., Sir Robert Stout: A Biography. Wellington: A.H. \& A.W. Reed, 1961.

Elliot, John, History in the Making. New Haven: Yale University Press, 2012.

English, Henry, ed. The Mining Almanack for 1849. London: The Mining Journal Office, 1849.

The Mining Manual and Almanack for 1851. London: The Mining Journal Office, 1850.

Evans, Julie, Edward Eyre: race and colonial governance. Dunedin: University of Otago Press, 2005.

Fargher, Ray, The best man who ever served the crown? A life of Donald McLean. Wellington: Victoria University Press, 2007.

Fitzpatrick, Brian, The British Empire in Australia: An Economic History 18341939. Melbourne: Melbourne University Press, 1941.

Fox, William, The Six Colonies of New Zealand. London: John W. Parker and Son, 1851.

Fulton, Christina, Lella: A Poem. Dunedin: Evening Star, 1868. 
Gardner, W.J., Colonial Cap and Gown: Studies in Mid-Victorian Universities of Australasia. Christchurch: University of Canterbury, 1979.

Garner, Jean, By His Own merits: Sir John Hall-Pioneer, Pastoralist and Premier. Hororata, New Zealand: Dryden Press, 1995.

Gilkison, Robert, Early Days in Dunedin. Auckland: Whitcombe and Tombs, 1938.

Gisborne, William, New Zealand Rulers and Statesmen 1840 to 1885. London: Sampson Low, Marston, Searle, \& Rivington, 1886.

Godley, John R, ed. Letters from Early New Zealand by Charlotte Godley 18501853, Christchurch: Whitcombe \& Tombs, 1951.

Goldsmith, Paul, We Won, You Lost, Eat That! A political history of tax in New Zealand since 1840. Auckland: David Ling, 2008.

Graham, Jeanine, Frederick Weld, Auckland: Auckland University Press, 1983.

_ 'Settler Society', in Geoffrey Rice, ed. Oxford History of New Zealand. 2nd edn., Auckland: Oxford University Press, 1992.

Greif, Stuart W. and Knight, Hardwicke, Cutten: Letters Revealing the Life and Times of William Henry Cutten the Forgotten Pioneer. Dunedin: Stuart Greif and Hardwicke Knight, 1979.

Hall-Jones, F.G., Historical Southland. Invercargill: Southland Historical Committee, 1945.

Hall-Jones, John, Martins Bay, A National Parks Centennial 1987-88 Publication. Invercargill: Craig Printing Co., 1987.

Hamer, David, The New Zealand Liberals: The Years of Power, 1891-1912. Auckland: Auckland University Press, 1988.

Hamilton, Nigel, Biography: A Brief History. Cambridge, Mass: Harvard University Press, 2007.

Harper, Marjory, Emigration from North East Scotland. Vol. 1. 'Willing Exiles'. Aberdeen: Aberdeen University Press, 1988.

Emigration from North East Scotland. Vol. 2. 'Beyond the Broad Atlantic'. Aberdeen: Aberdeen University Press, 1988.

Adventurers and Exiles: The Great Scottish Exodus. London: Profile, 2003.

Harper, Marjory, ed. Emigrant Homecomings: The Return Movement of Emigrants, 1600 - 2000. Manchester: Manchester University Press, 2005.

Harper, Marjory and Vance, Michael E., eds. Myth, Migration and the Making of Memory: Scotia and Nova Scotia C. 1700-1900. Published for the Gorsebrook Research Institute for Atlantic Canada Studies by Fernbrook Publishing, Halifax, Canada, and John Donald, Edinburgh, 1999.

Hawke, Gary, The Making of New Zealand: An Economic History. Cambridge: Cambridge University Press, 1985.

Hay, J.N., Epidemics and pandemics: their impacts on human history. Santa Barbara, Ca: ABC-CLIO, 2005. 
Herman, Arthur, How the Scots Invented the Modern World. New York: Crown Publishers, 2001.

Hight, James, and Straubel, C. R., Gen. eds., A History of Canterbury. 3 Vols. Christchurch: Whitcombe \& Tombs, 1957-1971.

Hirst, John, The Australians: Insiders \& Outsiders on the National Character since 1770. Melbourne: Black, 2007.

Hocken, T.M., Contributions to the Early History of New Zealand (Settlement of Otago). London: Sampson, Low, Marston and Co., 1898.

Horsman, Alan, ed. The Diary of Alfred Domett, 1872-85. London: Oxford University Press, 1953.

Houston, R.A., and Knox W.W.J., eds. The New Penguin History of Scotland: From the Earliest Days to the Present Day. London: Allen Lane/Penguin in association with the National Museums of Scotland, 2001.

Hursthouse, Charles, New Zealand: The "Britain of the South". 2nd edn. London: Edward Stanford, 1861.

Jourdain, W.R., Land Legislation and Settlement in New Zealand, Wellington: Government Printer, 1925.

Kennedy, Junior, David, Kennedy's Colonial Travel: A Narrative of a Four Years' Tour through Australia, New Zealand, Canada, \&C. London: Edinburgh Publishing Company, 1876.

King, Michael, The Penguin History of New Zealand. Auckland: Penguin, 2003.

Le Cren, Denis J., The Rich and Macandrew Families 1280-1993. Nelson: Denis Le Cren, 1993.

Locke, Elsie, The Gaoler. Palmerston North: The Dunmore Press, 1978.

Macandrew, James, Address to the People of Otago. Dunedin: Mills, Dick and Co., 1875.

Macdonald, Phillida, Eliza's Journal. Christchurch: P. Macdonald, 2000.

MacKenzie, John M., ed., The Victorian Vision: Inventing New Britain, London: V \& A Publications, 2004.

MacLaren, Alan A., Religion and Social Class: The Disruption Years in Aberdeen. London \& Boston: Routledge \& Kegan Paul, 1974.

Macmillan, David S., Scotland and Australia, 1788-1850: Emigration, Commerce and Investment. Oxford: Clarendon, 1967.

McAloon, Jim, Nelson: A Regional History. Whatamango Bay, Queen Charlotte Sound, New Zealand: Cape Catley Ltd, 1997.

No Idle Rich: the Wealthy in Canterbury \& Otago 1840-1914. Dunedin: University of Otago Press, 2002.

McCalla, Doug, Planting the Province: The Economic History of Upper Canada. Toronto: University of Toronto Press, 1993.

McDonald, K.C., City of Dunedin: A Century of Civic Enterprise. Dunedin: Dunedin City Corporation, 1965. 
McEldowney, Dennis, ed. Presbyterians in Aotearoa 1840-1990. Wellington: Presbyterian Church of New Zealand, 1990.

McIntosh, A.D., Marlborough: A Provincial History. Blenheim: Marlborough Provincial Historical Committee, 1940.

McIntyre, W.D., ed. The Journal of Henry Sewell 1853-7. 2 Vols. Christchurch: Whitcoulls, 1980.

McIvor, Timothy, The Rainmaker A Biography of John Ballance Journalist and Politician 1839-1893. Auckland: Heinemann Reid, 1989.

McLean, Gavin, Otago Harbour: Currents of Controversy. Dunedin: Otago Harbour Board, 1985.

-The Southern Octopus: The Rise of a Shipping Empire. Wellington: New Zealand Ship \& Marine Society, 1990.

The Governors: New Zealand's Governors and Governors-General. Dunedin: Otago University Press, 2006.

McLintock, A.H., The Port of Otago. Dunedin: Whitcombe \& Tombs, 1951.

Crown Colony Government in New Zealand. Wellington: Government Printer, 1958.

The History of Otago: The Origins and growth of a Wakefield Class Settlement. Dunedin: Otago Centennial Historical Publications, 1949; reprint, Christchurch: Capper Press, 1975.

McLintock, A.H., and Wood, G.A., The Upper House in Colonial New Zealand. Wellington: Government Printer, 1987.

McKean, John, The Church in a Special Colony: A History of the Presbyterian Synod of Otago \& Southland 1866-1991. Dunedin: Synod of Otago and Southland, Presbyterian Church of Aotearoa New Zealand, 1994.

Mander-Jones, Phyllis, Manuscripts in the British Isles Relating to Australia, New Zealand, and the Pacific. Canberra: Australian National University Press, 1972.

Martin, Ged., "Edward Gibbon Wakefield: Abductor and Mystagogue”, Paper presented at the Edward Gibbon Wakefield and New Zealand 1830-1865: A Reconsideration Conference. Wellington: National Library, 1996.

Martin, John, The House: New Zealand's House of Representatives 1854-2004. Palmerston North: Dunmore Press, 2004.

Merrington, E.N., A Great Coloniser: Rev Dr Thomas Burns. Dunedin: Otago Daily Times and Witness Newspapers, 1929.

Morris, R.J. Class, Sect and Party: The Making of the British Middle Class, Leeds, 1820-1850. Manchester: Manchester University Press, 1990.

-Men, Women and Property in England, 1780-1870: A Social and Economic History of Family Strategies Amongst the Leeds Middle Classes. Cambridge: Cambridge University Press, 2005.

Moncrieff-Spittle, Malcolm, ed. The Lost Journal of Edward Jerningham Wakefield Being an Account of His Exploits and Adventures in New 
Zealand in the Years 1850-1858, Including: His Various Visitations, Conversations \& Observations \&C. \&C. To Which Is Added an Introduction. Dunedin: Kilmog Press, 2008.

Morrell, William, New Zealand. London: Ernest Benn, 1935.

The Provincial System in New Zealand: 1852-76. 2nd edn. Christchurch: Whitcombe \& Tombs, 1964.

Morrell, William, and Hall, D.O.W., A History of New Zealand Life. Christchurch: Whitcombe and Tombs, 1957.

Nenadic, Stana, 'The Rise of the Urban Middle Classes' in Devine, Tom and Mitchison, Rosalind, eds. People and Society in Scotland Volume I: 1760-1830. Edinburgh: John Donald in association with The Economic and Social History Society of Scotland, 1988.

'Political Reform and the "Ordering” of Middle-Class Protest.' in Devine, Tom, ed., Conflict and Stability in Scottish Society 1700-1850: Proceedings of the Scottish Historical Studies Seminar University of Strathclyde 1988-89. Edinburgh: John Donald, 1990, pp 65-82.

'The Victorian Middle Classes' in Fraser, W. Hamish and Maver, Irene, eds. Glasgow, People and Society in Scotland, Volume II: 1830 to 1912. Manchester and New York: Manchester University Press, 1996, pp. 265-269.

Nolan, Melanie, Kin: a collective biography of a New Zealand working-class family. Christchurch: Canterbury University Press, 2005.

Olssen, E., A History of Otago, Dunedin: John McIndoe, 1984.

Otago Provincial Government, The Province of Otago in New Zealand: Its Progress, Present Condition, Resources, and Prospects. Dunedin: Otago Provincial Government, 1868.

Otago, Southland and South Canterbury Provincial Almanac \& Directory (1875-1909), 'Sketch of the Life of James Macandrew,' Dunedin: Mills, Dick \& Co., 1886.

Palenski, Ron, The Making of New Zealanders. Auckland: Auckland University Press, 2012.

Palmer, Bryan in M. Brook Taylor, ed., Canadian History, A Reader's Guide, Vol. 1: Beginnings to Confederation. Toronto: University of Toronto Press, 1994.

Pearce, G.L., The Scots of New Zealand, Auckland: Collins, 1976.

Phillips, Jock \& Hearn, Terry, Settlers: New Zealand Immigrants from England, Ireland \& Scotland 1800-1945. Auckland: Auckland University Press, 2008.

Polaschek, R.J., ed. Local Government in New Zealand. Wellington and London: New Zealand Institute of Public Administration and OUP, 1956.

Reed, A.H., The Story of Early Dunedin, Wellington: A.H. \& A.W. Reed, 1956. 
Registrar-General of New Zealand, Statistics of New Zealand for 1853, 1854, 1855, and 1856. Auckland: 1858.

- Statistics of New Zealand for 1887. Auckland: 1888.

Richards, Eric, Britannia's Children. London: Hambledon and London, 2004.

Robinson, Neil, To the ends of the earth: Norman McLeod and the Highlanders' migration to Nova Scotia and New Zealand. Auckland: HarperCollins, 1997.

Roxburgh, Irvine, Jacksons Bay: A Centennial History. Wellington: A.H. \& A.W. Reed, 1976.

Rutherford, J., Sir George Grey: A study in Colonial Government. 2nd edn., London: Cassell, 1961.

Saunders, Alfred, History of New Zealand. Vol. II, Christchurch: Smith, Anthony, Sellars, and Co., 1899.

Scholefield, Guy, A Dictionary of New Zealand Biography. 2 Vols. Wellington: Department of Internal Affairs, 1940.

-Notable New Zealand Statesmen: Twelve Prime Ministers. Christchurch: Whitcombe and Tombs, 1946.

New Zealand Parliamentary Record. Wellington: Government Printer, 1950.

Scholefield, Guy, ed. The Richmond-Atkinson Papers. 2 Vols. Wellington: R. E. Owen, Government Printer, 1960.

Siegfried, Andre, Democracy in New Zealand. London: English edn. translated by E.V. Burns, G. Bell and Sons, 1914.

Simpson, Tony, The Immigrants: The Great Migration from Britain to New Zealand, 1830-1890. Auckland: Godwit Press, 1997.

Sinclair, Keith, A History of New Zealand. London: Penguin, 1959.

Smith, Janet Adam, John Buchan, a Biography. London: Rupert Hart-Davies, 1965.

Snedden, Fleur, King of the Castle: A Biography of William Larnach. Auckland: David Bateman, 1997.

Stewart, William Downie, ed. The Journal of George Hepburn. Dunedin: Coulls Somerville Wilkie and A.H. Reed, 1934.

-The Right Honourable Sir Francis H.D. Bell: His Life and Times. Wellington: Butterworth \& Co, 1937.

William Rolleston. Christchurch: Whitcombe \& Tombs, 1940.

Stone, R.C.J., Young Logan Campbell. Auckland: Auckland University Press, 1982.

The Father and His Gift: John Logan Campbell's Later Years. Auckland: Auckland University Press, 1987.

Stuart, Peter, Edward Gibbon Wakefield in New Zealand: His Political Career 1853-54, Wellington: Price Milburn for Victoria University of Wellington, 1971. 
Temple, Philip, A Sort of Conscience: The Wakefields. Auckland: Auckland University Press, 2003.

Trotter, Olive, Pioneers Behind Bars: Dunedin Prison and its Earliest Inmates, 1850-1870. Dunedin: Olive Trotter, 2002.

—Dunedin's Spiteful Socrates, J.G.S. Grant. Dunedin: Olive Trotter, 2005.

John Larkins Cheese Richardson: 'The Gentlest, Bravest and Most Just of Men'. Dunedin: Otago University Press, 2010.

Turnbull, Michael, The New Zealand Bubble; the Wakefield Theory in Practice. Wellington: Price, Milburn, 1959.

Wade, Richard, The Urban Frontier: Pioneer Life in Early Pittsburgh, Cincinnati, Lexington, Louisville, and St. Louis. Chicago: University of Chicago Press, 1976.

Wakefield, Edward Jerningham, Adventure in New Zealand. ed. Joan Stevens, abridged edn. Christchurch: Whitcombe and Tombs, 1955.

The London Journal of Edward Jerningham Wakefield. ed. Joan Stevens, Alexander Turnbull Library Monograph No 4. Wellington: Alexander Turnbull Library \& Victoria University of Wellington, 1972.

Watt, W.J., Dunedin's Historical Background: An Historical Geography of Dunedin Covering the Period 1840-1900. Dunedin: Dunedin City Council, 1972.

Westgarth, William, The Colony of Victoria. London: Sampson Low, Son, and Marston, 1864.

Wilkinson, J.D., Early New Zealand Steamers. Vol. I. Wellington: Maritime Historical Productions, 1866.

Wilson, John, The Gazetteer of Scotland, published 1882, 3rd printing 2002.

Wilson, John, Reminiscences of the Early Settlement of Dunedin and South Otago. Dunedin: J Wilkie and Co., 1912.

Wilson, T.G., The Grey Government 1877-9. Auckland: Auckland University College, History Series No. 5, Bulletin No. 45, 1954.

The Rise of the New Zealand Liberal Party 1880-90. Auckland: Auckland University College, History Series No. 6, Bulletin No. 48, 1956.

Wolmar, Christian, Fire \& Steam: A New History of the Railways in Britain. London: Atlantic Books, 2007.

Wright-St Clair, Rex E., Thoroughly a Man of the World: A Biography of Sir David Monro, M. D. Christchurch: Whitcombe \& Tombs, 1971.

\section{$\underline{\text { Electronic sources }}$}

Baptismal Register, Old Machar Church, Aberdeen, 18/05/1819 MCANDREW, JAMES [O. P. R. Births 168/B00 00500610 OLD MACHAR].

http://www.scotlandspeople.gov.uk/ 
Encyclopaedia Britannica, 9th Edition (1875) and 10th Edition (1902),

Encyclopaedia Britannica Co., London.

http://www.1902encyclopedia.com/A/ABE/aberdeen.html

Hall, D, 'MACANDREW, James', from An Encyclopaedia of New Zealand, edited by A. H. McLintock, originally published in 1966, Te Ara-The Encyclopedia of New Zealand, updated 18-Sep-2007.

http://www.TeAra.govt.nz/1966/M/MacandrewJames/en

London Census 1841 0bbba32d01db8027d3a224b2464d608e.pdf Folio Reference, HO107/1052/4/ F39.

http://www.ukcensusonline.com/search/index.php?fn=james\&sn=macandrew\&pho netic mode $=1 \&$ event $=1841$

Olssen, Erik, 2007, 'Macandrew, James 1819?-1887', Dictionary of New Zealand Biography, updated 22 June 2007. http://www.dnzb.govt.nz/.

\section{Articles}

Attard, Bernard, 'From Free-Trade Imperialism to Structural Power: New Zealand and the Capital Market, 1856-68', The Journal of Imperial and Commonwealth History, 35, No. 4, 2007, pp. 505-27.

Banner, Lois W., 'Biography as History', American History Review, 114, No. 3, 2009, pp. 579-86.

Barber, L. H., 'James Gibbs' Heresy Trial, 1890', The New Zealand Journal of History, 12, No. 2, 1978, pp. 146-57.

Bowie, Patricia, 'The Shifting Gold Rush Scenario: California to Australia to New Zealand', Californians, 6, No. 1, 1988, pp. 12-30.

Brooking, Tom, "'Busting Up" The Greatest Estate of All', The New Zealand Journal of History, 26, No. 1, 1992, pp. 78-98.

'Silences of Grass: Retrieving the Role of Pasture Plants in the Development of New Zealand and the British Empire', The Journal of Imperial and Commonwealth History, 35, No. 3, 2007, pp. 417-35.

Brown, Judith, "Life Histories" And the History of Modern South Asia', American History Review, 114, No. 3, 2009, pp. 587-95.

Brown, Kate, 'Gridded Lives: Why Kazakhstan and Montana are nearly the Same Place', The American Historical Review, 106, No. 1, 2001, pp. 17-48.

Bruckner, Phillip, 'Presidential Address: Whatever happened to the British Empire?' Journal of the Canadian Historical Association, 4, No. 1, 1993, pp. 3-32.

Cannadine, D., 'The Empire Strikes Back', Past \& Present, 147, 1995, pp 180-194.

Cookson, John, 'How British? Local Government in New Zealand to c. 1930', The New Zealand Journal of History, 41, No. 2, 2007, pp. 143-60.

Crawford, Scott A. G. M. 'Recreation in Pioneering New Zealand: Some Early Newspaper Sources in Otago Province, 1848-1861', Victorian Periodicals Review, 23, No. 3, 1990, pp. 97-103. 
Dalziel, Raewyn, "The "Continuous Ministry" Revisited', The New Zealand Journal of History, 21, No. 1, 1987, pp. 46-61.

'Book Review: The New Zealand Liberals. The Years of Power, 18911912', The New Zealand Journal of History, 23, No. 2, 1989, pp. 193-195.

Dunbabbin, J. P. D., “The Revolt of the Field”: The Agricultural Labourers' Movement in the 1870s', Past \& Present, 26(1), 1963, pp. 68-97.

Bulletin, Friends of the Hocken Collection, 'New Zealand's Nine Provinces (185376)', No. 31, Dunedin, 2000.

_'Importers, merchants \& warehousemen', No. 52, Dunedin, 2006.

—'Shipping', No. 57, Dunedin, 2008.

—_The Squatters Club', No. 58, Dunedin, 2008.

Gibbons, Peter, 'Cultural Colonization and National Identity', The New Zealand Journal of History, 36, No. 1, 2002, pp. 4-15.

Hall, Jacquelyn Dowd, "YYou Must Remember this": Autobiography as Social critique', The Journal of American History, 85, No. 2, 1998, pp. 439-65.

Hamer, David, 'The Agricultural Company and New Zealand Politics, 1877-1886', Historical Studies: Australia and New Zealand, 10, No. 38, 1962, pp. 141164.

Harper, Marjory, 'A Century of Scottish Emigration to New Zealand', Immigrants \& Minorities, 29:2, 2011, p. 2212.

Hopkins, A. G., 'Back to the Future: From National History to Imperial History', Past \& Present, 164(1), 1999, pp. 198-243.

'Gentlemanly Capitalism in New Zealand', Australian Economic History Review, 43, No. 3, 2003, pp 287-97.

Hunt, Chris, 'Banking crises in New Zealand-an historical perspective', Bulletin, Reserve Bank of New Zealand, 72, No. 4, 2009.

Kearsley, G. W, Hearn, T. J. and Brooking, T. W. H., 'Land Settlement and Voting Patterns in the Otago Provincial Council, 1863-1872', The New Zealand Journal of History, 18, No. 1, 1984, pp 19-33.

McAloon, Jim, 'The Colonial Wealthy in Canterbury and Otago: No Idle Rich', The New Zealand Journal of History, 30, No. 1, 1996, pp. 43-60.

'New Zealand and the Economics of Empire', History Now, No. 7, 2001, p. $12-16$.

'Gentlemanly Capitalism and Settler Capitalists: Imperialism Dependent Development and Colonial Wealth in the South Island of New Zealand', Australian Economic History Review, 42, No. 2, 2002, pp. 204-23.

'Class in Colonial New Zealand', The New Zealand Journal of History, 38, No. 1, 2004, pp. 3-21.

Mackenzie, John M., 'On Scotland and the Empire', The International History Review, 15, No. 4, 1993, pp. 714-39. 
MacKenzie, John \& Patterson, Brad, 'The New Zealand Scots in International Perspective: An Introduction', Immigrants \& Minorities, 29:2, 2011, p. 153.

Morris, R. J., 'Samuel Smiles and the Genesis of Self-Help; the Retreat to a Petit Bourgeois Utopia', The Historical Journal, 24, No. 1, 1981, pp. 89-109.

Nasaw, David, 'Introduction. Historians and Biography' American Historical Review, 114, No. 3, 2009.

Olssen, Erik, 'Where To From Here? Reflections on the Twentieth-Century Historiography of Nineteenth-Century New Zealand', The New Zealand Journal of History, 26, No. 1, 1992, pp. 54-77.

'Mr. Wakefield and New Zealand as an Experiment in Post-Enlightenment Experimental Practice', The New Zealand Journal of History, 31, No. 2, 1997, pp. 197-218.

Pickens, K. A., 'The Writing of New Zealand History: A Kuhnian Perspective', Historical Studies, 17, 1977, pp. 384-98.

Pickles, Kate, 'Empire Settlement and Single British Women as New Zealand Domestic Servants during the 1920s', The New Zealand Journal of History, 35, No. 1, 2001, pp. 22-44.

Rosanwoski, G. J., 'The West Coast Railways and New Zealand Politics, 18781888', The New Zealand Journal of History, 4, No. 1, 1970, pp. 34-53.

Rubinstein, William D., 'No Idle Rich: The Wealthy in Canterbury and Otago, 1840-1914', The English Historical Review, 118, No. 479, 2003, p 14-17.

Solomon Roberts, 'Obituary of George Crane', Journal of the Franklin Institute, 41, No. 3, 1846, p. 214.

Stone, R. C. J., 'The Maori Lands Question and the Fall of the Grey Government, 1879', The New Zealand Journal of History, 1, 1967, pp. 51-74.

Wakefield, Edward Jerningham, 'What Will They Do in the General Assembly?' Times, Christchurch, 1863.

Wright, R. E., 'Bank ownership and lending patterns in New York and Pennsylvania, 1781-1831', Business History Review, 73, 1999.

\section{Theses}

Blackstock, Raewyn, 'The office of Agent-General for New Zealand in the United Kingdom, 1870-1905', PhD thesis, Victoria University of Wellington, 1970.

Bunce, Roderick, 'The Trust Funds for Religious and Educational Uses at Otago 1842 to 1866', MA thesis, University of Otago, 1982.

Cook, A. H., 'The Slowly-Dying Cause: A Study of Otago Provincialism after the Abolition of the Provinces 1975-1884', MA thesis, University of Otago, 1969.

Ellis, M. A., 'James Macandrew and His Times', MA thesis, University of Otago, Dunedin, 1926.

Hamer, David, 'The Law and the Prophet: A Political Biography of Sir Robert Stout (1844-1930)', MA thesis, University of Auckland, 1960. 
Lenihan, Rebecca, 'From Alba to Aotearoa: Profiling New Zealand's Scots Migrants, 1840-1920', PhD thesis, Victoria University of Wellington, 2010.

McIvor, Timothy, 'On Ballance: a biography of John Ballance, journalist and politician, 1839-1893', PhD thesis, Victoria University of Wellington, 1984.

Mullins, R. M., 'The Division of Power Between the General and Provincial Governments 185367', MA thesis, Victoria University of Wellington, 1953.

Sinclair, Fergus, 'High Street quaking: a history of Dunedin's "Inner circle", $\mathrm{PhD}$ thesis, University of Otago, 1996.

\section{Unpublished Papers}

Brooking, Tom, speech to Rich and Macandrew Family Reunion, 15 February 2001, Dunedin.

Letter: Marsha Donaldson to Tom Brooking, 5 September 1985: 'from an article on Macandrew sent to me by Blanche Jensen, Dunedin. Mr Macandrew was educated at Fortrose Academy, Ayrshire and subsequent at Aberdeen.'

Letter: David Walton, Asst Registrar, Ayr Academy to Tom Brooking, 30 April 1985. 